RENATO JORGE GALVÃO TEIXEIRA

\title{
ANÁLISE DO IMPACTO DO USO DA RE-SETORIZAÇÃO DINÂMICA NA CARGA DE TRABALHO DO CONTROLADOR DE TRÁFEGO AÉREO POR MEIO DE SIMULAÇÕES COMPUTACIONAIS
}


RENATO JORGE GALVÃO TEIXEIRA

\section{ANÁLISE DO IMPACTO DO USO DA RE-SETORIZAÇÃO DINÂMICA NA CARGA DE TRABALHO DO CONTROLADOR DE TRÁFEGO AÉREO POR MEIO DE SIMULAÇÕES COMPUTACIONAIS}

Dissertação apresentada à Escola Politécnica da Universidade de São Paulo para a obtenção do título de Mestre em Engenharia Elétrica

Área de Concentração: Sistemas Digitais

Orientador: Prof. Dr. Paulo Sérgio Cugnasca 
Este exemplar foi revisado e alterado em relação à versão original, sob responsabilidade única do autor e com anuência de seu orientador.

São Paul, 05 de Novembro de 2007.

Assinatura do autor

Assinatura do orientador

FICHA CATALOGRÁFICA

Teixeira, Renato Jorge Galvão

Análise do impacto do uso da re-setorização dinâmica na carga de trabalho do controlador de tráfego aéreo por meio de simulações computacionais / R.J.G. Teixeira. -- ed.rev. -- São Paulo, 2007.

$157 \mathrm{p}$.

Dissertação (Mestrado) - Escola Politécnica da Universidade de São Paulo. Departamento de Engenharia de Computação e Sistemas Digitais.

1.Transporte aéreo (Controle) 2.Jornada de trabalho (Setorização; Simulação computacional) I.Universidade de São Paulo. Escola Politécnica. Departamento de Engenharia de Computação e Sistemas Digitais II.t. 


\section{DEDICATÓRIA}

Primeiramente a Deus, pela oportunidade de estudo concedida. Ao meu Pai, o grande capitão em minha jornada nesta vida. À minha querida mãe, guerreira e vencedora, que tanto ajudou a cumprir mais esta etapa da vida. À minha irmã Yrma e ao meu Cunhado Carlos, pelo apoio. E à minha querida Karen, pelo carinho e amor. 


\section{AGRADECIMENTOS}

Ao Professor Dr. Paulo Sérgio Cugnasca pelo tempo dedicado na orientação dessa dissertação, sendo não só um meu Orientador, mas também um amigo que esteve sempre junto a nossa pesquisa.

Ao Dr. Ítalo Romani de Oliveira que esteve sempre pronto a ajudar e auxiliar está investigação de Mestrado.

Ao Major Eno Siewerdt, pelo auxílio na obtenção dos dados para a realização das simulações deste trabalho.

Ao distinto Bemildo Ferreira, por disponibilizar seus grandes conhecimentos em Tráfego Aéreo.

Ao controlador e pesquisador Derick Moreira Baum, por sua disposição em sempre compartilhar seus conhecimentos.

Ao Serviço Regional de Proteção ao Vôo de São Paulo (SRPV - SP), principalmente nas pessoas do Tenente Adolfo e do Tenente Carlos Heredia, que sempre nos ajudaram com muita boa vontade.

A ISA Software por conceder a licença universitária do software RAMS Plus para a Escola Politécnica da Universidade de São Paulo e pelo suporte prestado no seu uso.

Ao Unibanco, na pessoa do meu gestor Antônio Carlos C Gondim, pelo apoio e compreensão.

Aos colegas do Grupo de Análise de Segurança (GAS), pelo apoio, e à Escola Politécnica, pelo privilégio de proporcionar a oportunidade de realizar a minha Graduação e este Mestrado. 


\section{RESUMO}

A crescente demanda por transporte aéreo tem provocado um aumento na densidade do fluxo de aeronaves no espaço aéreo. A sobrecarga cada vez maior de aeronaves nos setores estáticos do espaço aéreo, cujos controles são de responsabilidade dos controladores de tráfego aéreo, provoca um estado de alerta constante no gerenciamento do tráfego aéreo. Uma única falha na monitoração e controle dos setores, realizadas pelos controladores de tráfego aéreo, pode por em risco a vida de centenas de pessoas. Para garantir a segurança do espaço aéreo, o controlador de tráfego aéreo tem que realizar várias tarefas no seu dia-a-dia, estando exposto a uma carga de trabalho. Uma das frentes de pesquisas que busca balancear a carga de trabalho dos controladores de tráfego aéreo é a Re-setorização Dinâmica. O objetivo deste trabalho de pesquisa é investigar como se comporta a carga de trabalho dos controladores de tráfego aéreo com a utilização da Re-setorização Dinâmica, tendo como estudo de caso um espaço aéreo brasileiro de alta densidade de aeronaves. 


\begin{abstract}
The growing demand for air transportation has caused an increase in the density of aircraft flow in the airspace. The overload of aircraft in airspace sectors, which are under the air traffic controllers' responsibility, causes a permanent alert state in the air traffic management. A single controller's fault with monitoring and controlling a sector may endanger hundreds of people's lives. The air traffic controller has to perform many activities daily in order to assure safety to the air space, being exposed to a certain workload. The Dynamic Resectorization is a research line in this direction that aims to balance the workload of the air traffic controllers. The goal of this research work is to investigate the behavior of the air traffic controller workload through the use of Dynamic Resectorization, having as a case study a Brazilian air space with high aircraft density.
\end{abstract}




\section{SUMÁRIO}

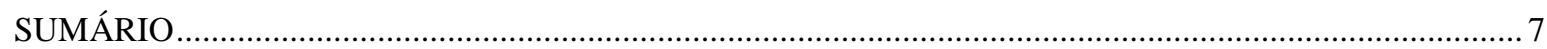

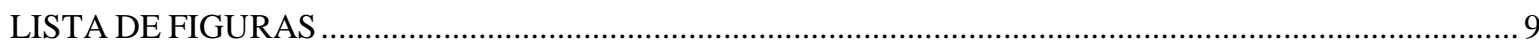

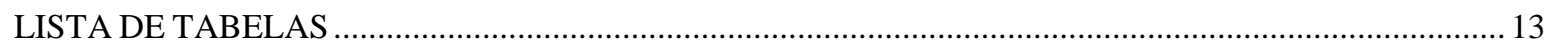

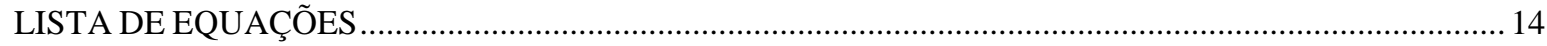

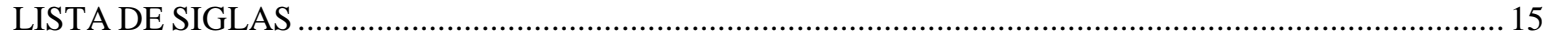

1 INTRODUÇÃO

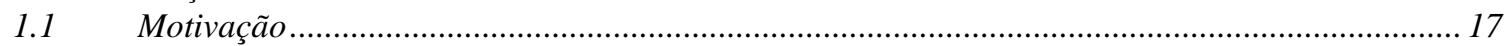

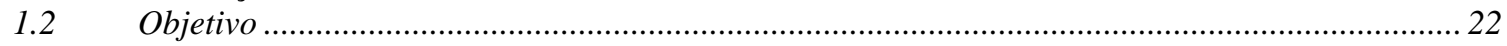

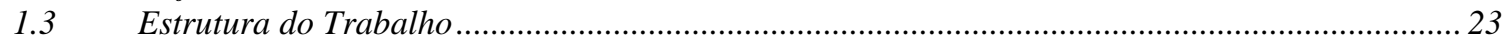

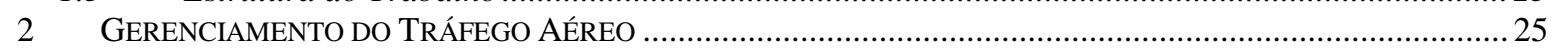

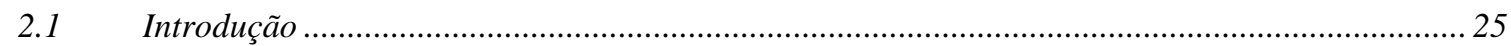

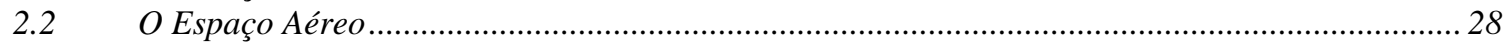

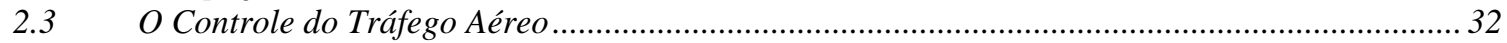

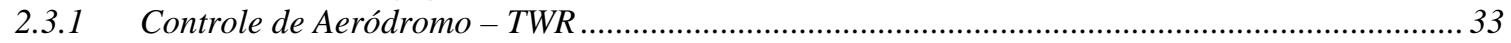

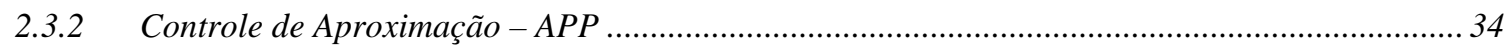

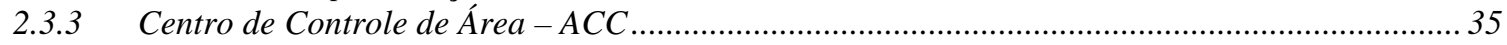

2.4 Pontos de Atenção Durante a Setorização do Espaço Aéreo ....................................................... 36

2.5 O Controlador de Tráfego Aéreo e a sua Carga de Trabalho........................................................3 39

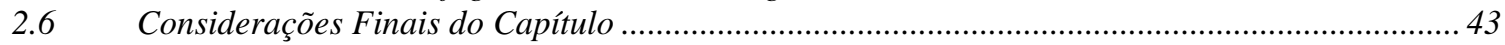

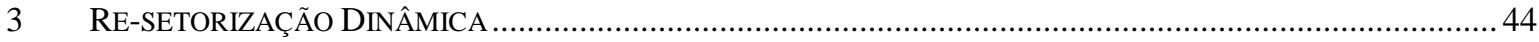

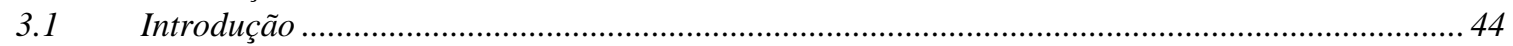

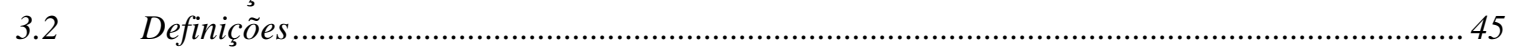

3.3 Um Exemplo de Re-setorização Dinâmica Irrestrita (RDI) ..................................................... 47

3.4 Exemplos Típicos de Aplicação da Re-setorização Dinâmica Limitada (RDL) ........................... 49

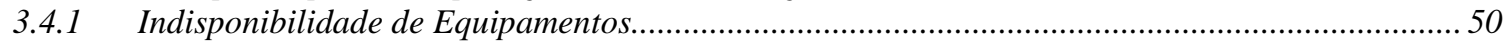

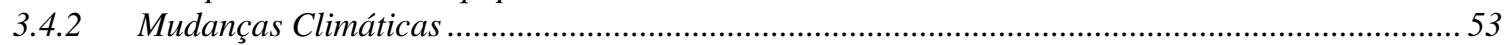

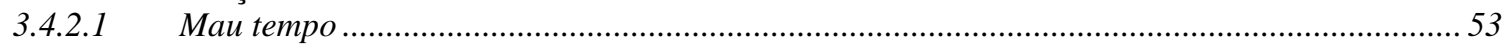

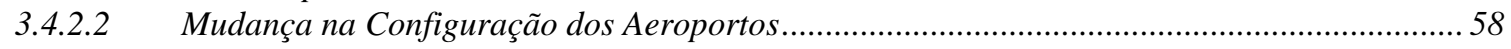

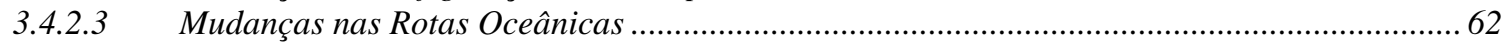

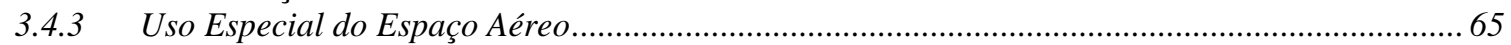

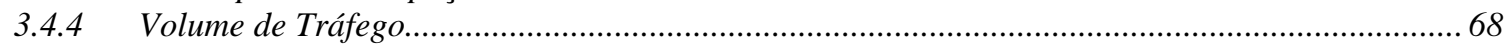

3.5 Considerações a Respeito da Re-setorização Dinâmica ......................................................... 71

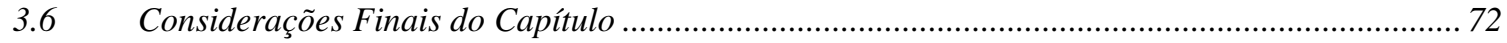

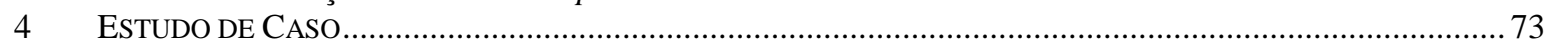

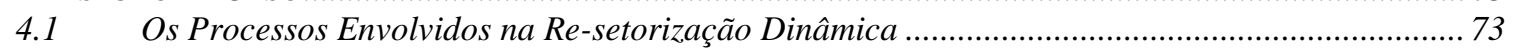

$4.2 \quad$ Um Breve Panorama da Re-setorização Dinâmica .............................................................. 76

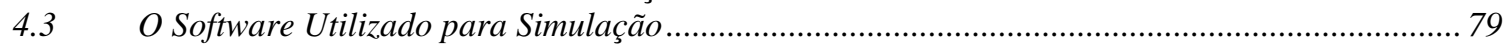

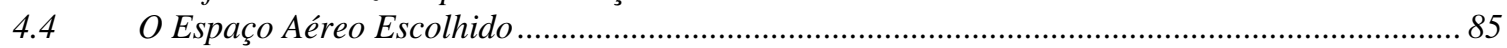

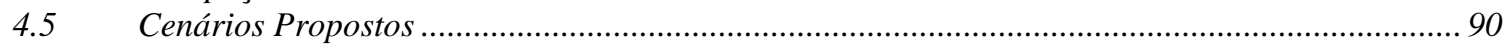

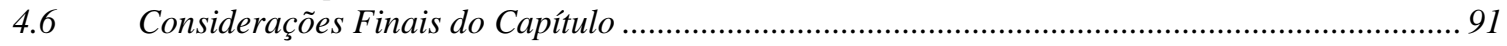

5 MODELAGEM E ANÁLISE dOS RESULTADOS DAS SIMULAÇÕES...............................................................92

5.1 Modelagem do Cenário e Tratamento dos Dados Utilizados nas Simulações ................................. 92

5.1.1 Definição das Configurações da TMA-SP e das Tarefas dos Controladores de Tráfego Aéreo

Utilizadas nas Simulações ................................................................................................................ 100

5.2 Estudo de Caso 1: Tráfego Atual com Alta Densidade de Aeronaves.......................................... 105

5.2.1 Análise da Carga de Trabalho do Controlador de Tráfego Aéreo................................................ 106

5.2.2 Análise do Número de Conflitos em Potencial ..................................................................... 115

5.2.3 Análise da Função Complexidade ...................................................................................... 116

5.2.4 Análise do Número de Aeronaves Controladas Simultaneamente pelo Controlador de Tráfego

Aéreo 118

5.3 Estudo de Caso 2: Tráfego Futuro com Crescimento no Número de Movimentações de Aeronaves 119

5.3.1 Comparativo do Cenário Atual com o Cenário Esperado para 2015 ........................................ 126

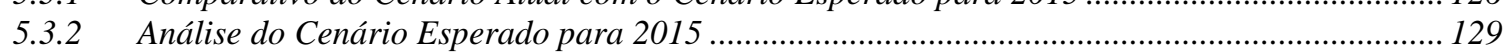

5.3.2.1 Análise da Carga de Trabalho do Controlador de Tráfego Aéreo ......................................... 129 
5.3.2.2 Análise do Número de Conflitos em Potencial ....................................................................... 134

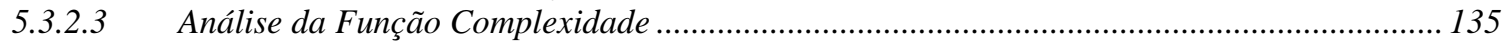

5.3.2.4 Análise do Número de Aeronaves Controladas Simultaneamente pelo Controlador de Tráfego Aéreo $\quad 137$

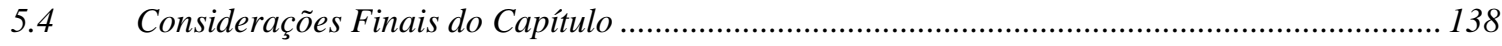

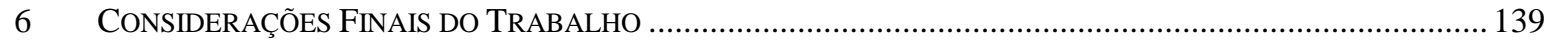

6.1 Comentários Finais sobre o Conteúdo Apresentado neste Trabalho de Pesquisa ………….......... 139

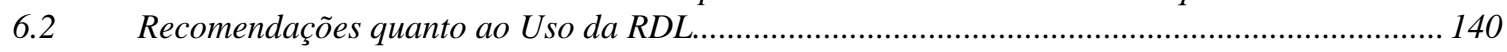

6.3 Comentários a Respeito do Software Utilizado nas Simulações Computacionais ....................... 141

$6.4 \quad$ Propostas de Trabalhos Futuros ................................................................................... 142

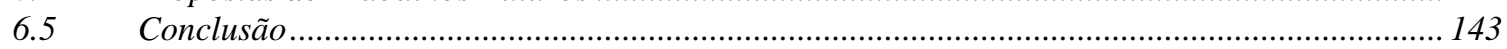

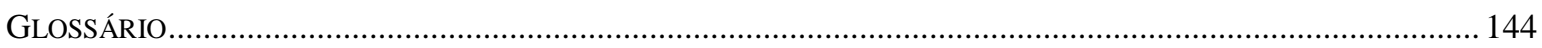

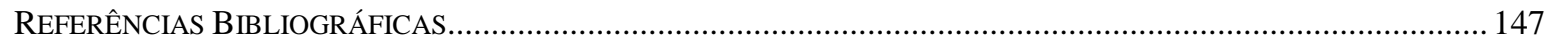

ANEXO I - MOVIMENTO DE AERONAVES POR HORA NA TMA SP E EM SEUS AEROPORTOS .......................... 151

ANEXO II - RESULTADOS DAS SIMULAÇÕES UTILIZANDO O TRÁFEGO DE 04/09/2006 E O ESPERADO PARA 2015 


\section{LISTA DE FIGURAS}

Figura 1 - Evolução do tráfego aéreo na TMA São Paulo, no período de 1988 a 2003

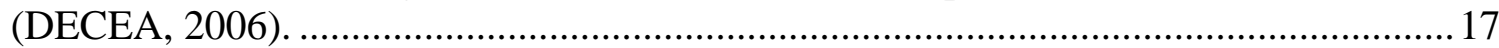

Figura 2 - Evolução dos acidentes na aviação civil no Brasil (ANAC, 2007)....................... 18

Figura 3 - Acidentes aeronáuticos na aviação civil do Brasil e evolução da frota (ANAC,

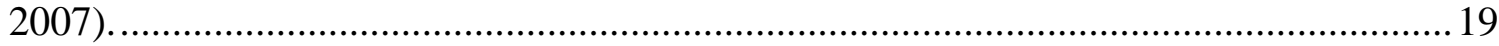

Figura 4 - Acidentes e fatalidades na aviação civil brasileira (ANAC, 2007). ....................... 20

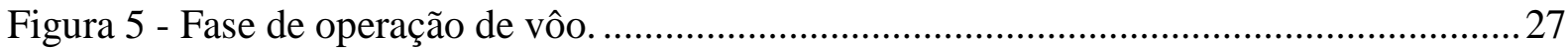

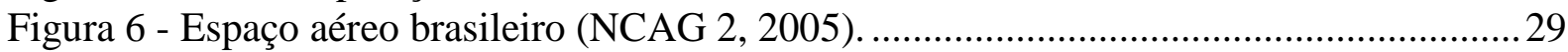

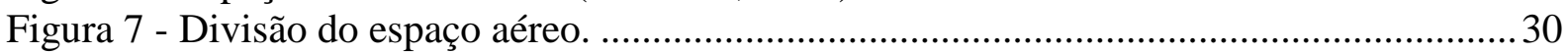

Figura 8 - Porcentagem de acidentes por fase de vôo, entre 1980 e 2001 (NLR, 2003).......... 34

Figura 9 - Os Centros de Controle de Área (ACCs) do Brasil e seus respectivos setores

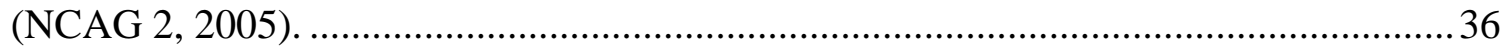

Figura 10 - Exemplo de setores convexos (TRANDAC, DUONG, 2003). ............................ 37

Figura 11 - Distância mínima entre um entroncamento e a borda de um setor (TRANDAC,

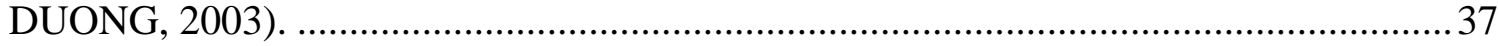

Figura 12 - Tempo mínimo de permanência de uma aeronave em um setor (TRANDAC,

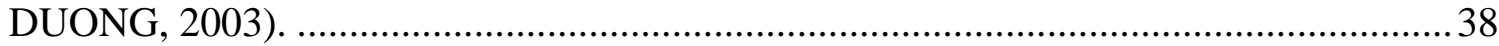

Figura 13 - Exemplo de um setor desconexo (TRANDAC, DUONG, 2003).........................38

Figura 14 - Exemplo de necessidade de re-configuração de rotas de aeronaves devido ao mau

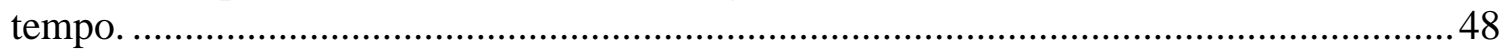

Figura 15 - Aplicação da RDI com re-configuração de setores devido ao mau tempo............ 49

Figura 16 - Controle do espaço aéreo antes da indisponibilidade de um radar (TABER,

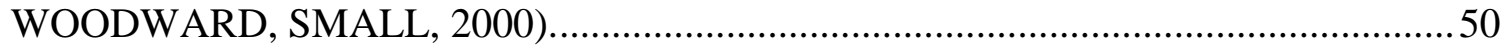

Figura 17 - Controle do espaço aéreo depois da indisponibilidade de um radar (TABER,

WOODWARD, SMALL, 2000)................................................................................... 51

Figura 18 - Cobertura de radar sobre o centro de Miami (TABER, WOODWARD, SMALL,

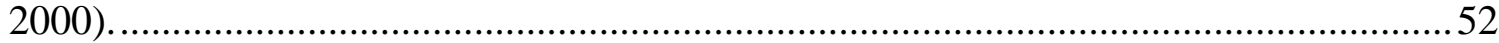

Figura 19 - Centro de Jacksonville com cobertura de radar para a área HOBEE (TABER,

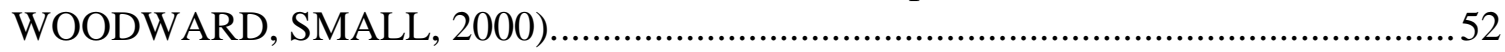

Figura 20 - Configuração genérica de dois setores com tempo bom (TABER, WOODWARD,

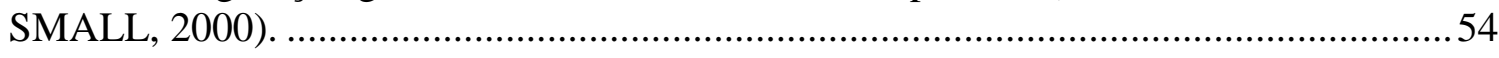

Figura 21 - Configuração genérica de dois setores com mau tempo (TABER, WOODWARD,

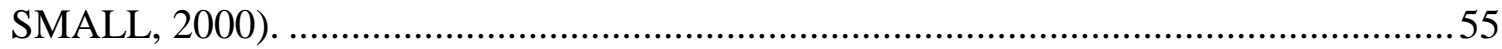

Figura 22 - Exemplo de re-setorização devido ao mau tempo (HADLEY et al., 2000). .........56

Figura 23 - Espaço aéreo de Orlando com tempo bom (TABER, WOODWARD, SMALL,

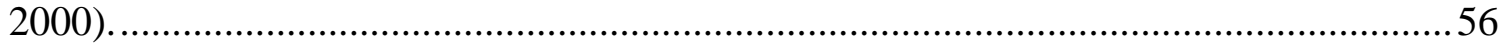

Figura 24 - Espaço aéreo de Orlando, com a área MALET, usada em casos de mau tempo

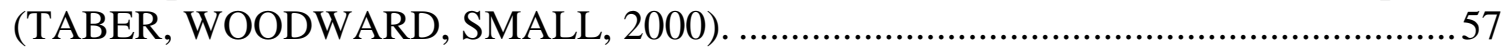

Figura 25 - Configuração genérica para operação Leste (TABER, WOODWARD, SMALL,

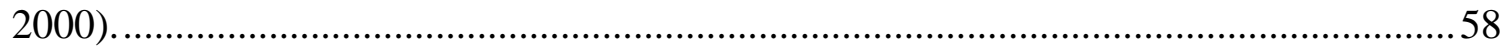

Figura 26 - Configuração genérica para operação Oeste (TABER, WOODWARD, SMALL,

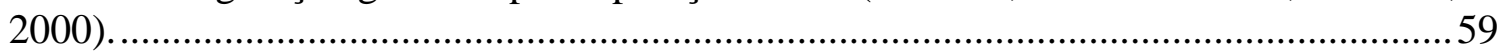

Figura 27 - Configuração genérica para operação Leste-Oeste (TABER, WOODWARD,

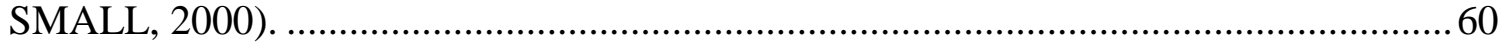

Figura 28 - TMA-Atlanta e Aeroporto de Atlanta (TABER, WOODWARD, SMALL, 2000). 
Figura 29 - Aeroporto de Atlanta na Operação Oeste (TABER, WOODWARD, SMALL, 2000).

Figura 30 - Aeroporto de Atlanta na operação Leste (TABER, WOODWARD, SMALL, 2000).

Figura 31 - Rotas oceânicas genéricas, nas configurações iniciais (TABER, WOODWARD,

SMALL, 2000).

Figura 32 - Rotas oceânicas genéricas, nas configurações revisadas (TABER, WOODWARD,

SMALL, 2000).

Figura 33 - Configuração de rotas oceânicas do centro de Oakland (TABER, WOODWARD,

SMALL, 2000).

Figura 34 - Rota genérica passando ao lado de um espaço aéreo de uso especial (TABER, WOODWARD, SMALL, 2000).

Figura 35 - Corredor genérico passando através de um espaço aéreo de uso especial (TABER,

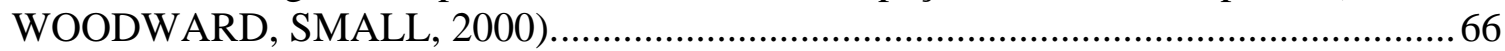

Figura 36 - Corredor da praia de Ormond - TORRY (TABER, WOODWARD, SMALL, 2000).

Figura 37 - Tráfego normal sobre uma configuração de um setor genérico (TABER,

WOODWARD, SMALL, 2000)

Figura 38 - Aumento do tráfego leste-oeste sobre uma configuração de um setor genérico

(TABER, WOODWARD, SMALL, 2000).

Figura 39 - Aumento do tráfego norte-sul sobre uma configuração de um setor genérico

(TABER, WOODWARD, SMALL, 2000).

Figura 40 - Configuração dos setores 01, 02 e 03 do Centro de Minneapolis e suas FPAs

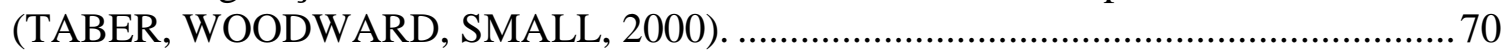

Figura 41 - Diagrama com estados e processos da re-setorização dinâmica (WILHELMSEN et

al., 1999a).

Figura 42 - Espaço aéreo hipotético setorizado................................................................... 76

Figura 43 - Re-setorização apenas redefinindo as bordas dos setores existentes......................77

Figura 44 - Re-setorização com a divisão de alguns setores.................................................. 78

Figura 45 - Re-setorização com o agrupamento de alguns setores. ........................................78

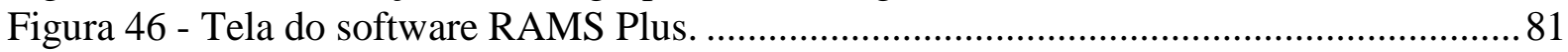

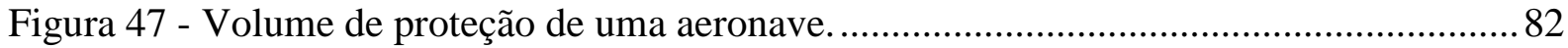

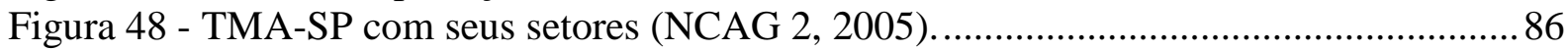

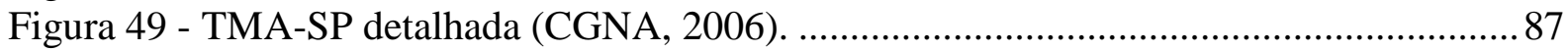

Figura 50 - Rotas especiais para vôo VFR sobre a TMA-SP (AIC 12/06, 2006). ................... 89

Figura 51- Rotas especiais para vôo VFR sobre a TMA-SP (DECEA, 2007)........................ 89

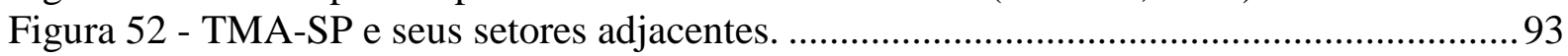

Figura 53 - Rotas SIDs e STARs da TMA-SP. .............................................................. 94

Figura 54 - Número de aeronaves e porcentagem de aeronaves na TMA-SP, por aeroporto, em

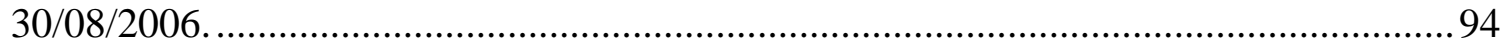

Figura 55 - Número de aeronaves e porcentagem de aeronaves na TMA-SP, por aeroporto, em $04 / 09 / 2006$.

Figura 56 - Número efetivo de aeronaves e porcentagem de aeronaves na TMA-SP, por aeroporto, em 30/08/2006.

Figura 57 - Número efetivo de aeronaves e porcentagem de aeronaves na TMA-SP, por

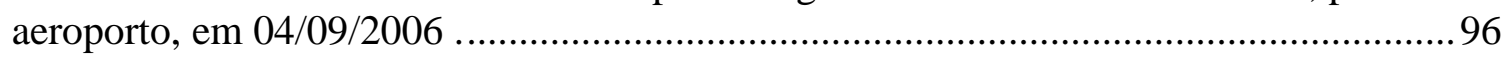

Figura 58 - Quadrantes com suas respectivas SIDs e STARs............................................ 98

Figura 59 - Fluxo da modelagem do cenário de simulação e de tratamento dos dados. ..........99

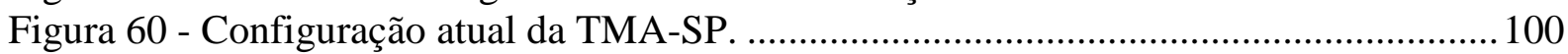

Figura 61 - Configuração da TMA-SP com agrupamento de setores.................................... 101 
Figura 62 - Configuração da TMA-SP com divisão de setores. 102

Figura 63 - Alocação das configurações de setores ao espaço aéreo durante um dia, usando a

RDL.

Figura 64 - Movimento de aeronaves (vôos IFR) na TMA-SP, em 30/08/2006. 105

Figura 65 - Soma dos pesos das tarefas realizadas pelos controladores de tráfego aéreo, por

setor, sem o uso da RDL, durante o dia 30/08/2006. ....

Figura 66 - Soma dos pesos das tarefas realizadas pelos controladores de tráfego aéreo, por setor, com o uso da RDL, durante o dia 30/08/2006.

Figura 67 - Soma, por hora, dos pesos das tarefas realizadas pelos controladores nos setores 1 , 1a e 1 b, sem e com o uso da RDL, durante o dia de 30/08/2006.

Figura 68 - Soma, por hora, dos pesos das tarefas realizadas pelo controlador nos setores 2, 2a e 2 b, sem e com o uso da RDL, durante o dia de 30/08/2006.

Figura 69 - Soma, por hora, dos pesos das tarefas realizadas pelo controlador de tráfego aéreo nos setores $0,1,2$ e 3, sem e com o uso da RDL, durante a madrugada do dia de 30/08/2006.

Figura 70 - Diferença entre os pesos das tarefas realizadas pelo controlador de tráfego aéreo, sem e com o uso da RDL, por hora, durante o dia 30/08/2006.

Figura 71 - Soma dos pesos das tarefas realizadas pelo controlador, com e sem o uso da RDL, durante o dia 30/08/2006.

Figura 72 - Quantidade de conflitos detectados na TMA-SP, sem o uso da RDL, por setor, em 30/08/2006.

Figura 73 - Quantidade de conflitos detectados na TMA-SP, com o uso da RDL, por setor, em 30/08/2006.

Figura 74 - Média ponderada do resultado da função de complexidade para a TMA-SP, sem o uso da DRL, por setor, para o dia 30/08/2006.

Figura 75 - Média ponderada do resultado da função de complexidade para a TMA-SP, com o uso da DRL, por setor, para o dia 30/08/2006.

Figura 76 - Número de aeronaves controladas simultaneamente nos setores da TMA-SP, sem o uso da RDL, em 30/08/2006.

Figura 77 - Número de aeronaves controladas simultaneamente nos setores da TMA-SP, com o uso da RDL, em 30/08/2006.

Figura 78 - Movimento de aeronaves (vôos IFR) na TMA-SP, em 04/09/2006.

Figura 79 - Projeção da evolução do número de movimentos (pouso e decolagem) em SBKP,

SBGR, SBSP e SBMT, de 2004 a 2025.

Figura 80 - Movimentos de aeronaves na TMA-SP, em 04/09/2006, e a projeção para 2015.

Figura 81 - Porcentagem de crescimento da soma dos pesos das tarefas realizadas pelo controlador de tráfego aéreo, por setor, sem o uso da RDL, esperado para $2015 \ldots \ldots \ldots . .126$

Figura 82 - Porcentagem de crescimento de conflitos detectado por setor na TMA-SP, sem o uso da RDL, esperado para 2015.

Figura 83 - Número de aeronaves controladas simultaneamente nos setores da TMA-SP, sem o uso da DRL, em 04/09/2006, e o número esperado para 2015.

Figura 84 - Soma dos pesos das tarefas realizadas pelos controladores, por setor, sem o uso da RDL, esperado para 2015.

Figura 85 - Soma dos pesos das tarefas realizadas pelos controladores, por setor, com o uso da RDL, esperado para 2015.

Figura 86 - Soma, por hora, dos pesos das tarefas realizadas pelos controladores nos setores 1 , 1a e 1b, sem e com o uso da DRL, esperado para 2015.

Figura 87 - Soma, por hora, dos pesos das tarefas realizadas pelos controladores nos setores 2 , 2a e 2 b, sem e com o uso da RDL, esperado para 2015. 
Figura 88 - Soma, por hora, dos pesos das tarefas realizadas pelos controladores nos setores 0 , 1,2 e 3, sem e com o uso da RDL, esperado para 2015.

Figura 89 - Soma dos pesos das tarefas realizadas pelo controlador, sem e com o uso da RDL,

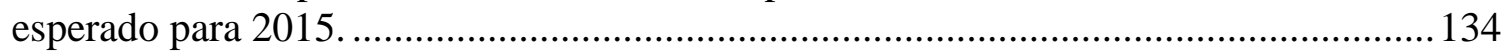

Figura 90 - Quantidade de conflitos detectados por setores na TMA-SP, sem o uso da RDL,

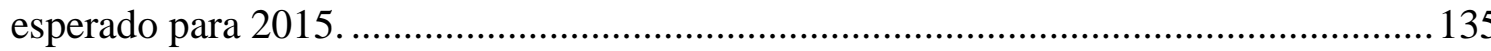

Figura 91 - Quantidade de conflitos detectados por setores na TMA-SP, com o uso da RDL, esperado para 2015.

Figura 92 - Média ponderada da função de complexidade, por setor, para a TMA-SP, sem o

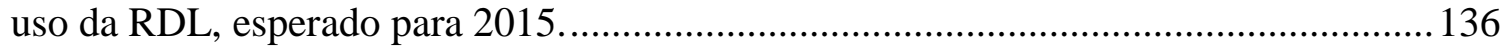

Figura 93 - Média ponderada da função de complexidade, por setor, para a TMA-SP, com o

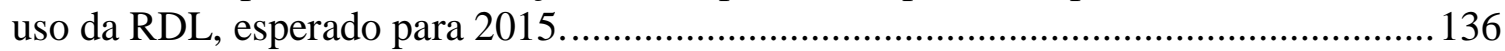

Figura 94 - Número de aeronaves controladas simultaneamente nos setores da TMA-SP, sem

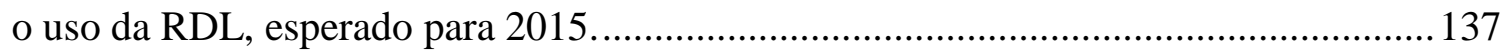

Figura 95 - Número de aeronaves controladas simultaneamente nos setores da TMA-SP, com

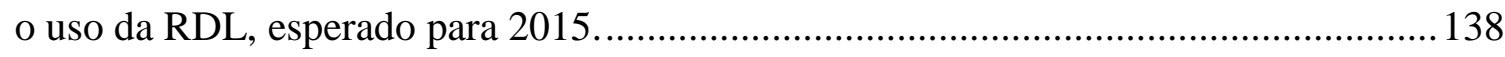




\section{LISTA DE TABELAS}

Tabela 1 - Zonas de controle do ATC 32

Tabela 2 - Capacidade da TMA-SP em movimento de aeronaves por hora.............................. 88

Tabela 3 - Famílias e versões de aeronaves comerciais. ..........................................................97

Tabela 4 - Tarefas realizadas pelo controlador nas simulações............................................ 104

Tabela 5 - Aeronaves de passageiros: taxas médias de crescimento anual (\%) para o mercado

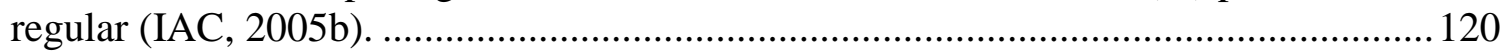

Tabela 6 - Crescimento esperado até 2025 do número de pouso e decolagem nos aeroportos da TMA-SP (IAC, 2005a).

Tabela 7 - Taxa média de crescimento anual na TMA-SP $(\%)$.

Tabela 8 - Projeção do número de movimentos na TMA-SP para 2015. 


\section{LISTA DE EQUAÇÕES}

Equação 1 - Número máximo de aeronaves controladas simultaneamente por um controlador de tráfego aéreo.

Equação 2 - Modelo simplificado do número máximo de aeronaves controladas simultaneamente por um controlador de tráfego aéreo. 


\section{LISTA DE SIGLAS}

\begin{tabular}{|c|c|c|}
\hline $\mathrm{ACC}$ & - & Area Control Center \\
\hline ACT & - & Aircraft Count \\
\hline ANAC & - & Agência Nacional de Aviação Civil \\
\hline ANG & - & Convergence Angle \\
\hline APP & - & Approach Control \\
\hline AS & - & Alert Service \\
\hline ATC & - & Air Traffic Control \\
\hline ATM & - & Air Traffic Management \\
\hline ATS & - & Air Traffic Service \\
\hline ATZ & - & Aerodrome Traffic Zone \\
\hline CGNA & - & Centro de Gerenciamento de Navegação Aérea \\
\hline $\mathrm{CoD}$ & - & Climbing or Descending \\
\hline CPA & - & Closest Points Approach \\
\hline CTA & - & Control Traffic Area \\
\hline CTR & - & Control Traffic Zone \\
\hline DECEA & - & Departamento de Controle do Espaço Aéreo \\
\hline DNS & - & Aircraft Density \\
\hline DR & - & Dynamic Resectorization \\
\hline ERC & - & En Route Charts \\
\hline EUROCONTROL & - & European Organisation for the Safety of Air Navigation \\
\hline FAA & - & Federal Aviation Administration \\
\hline FIR & - & Flight Information Region \\
\hline FIS & - & Flight Information Service \\
\hline FL & - & Flight Level \\
\hline FPA & - & Fix Posting Area \\
\hline IAC & - & Instituto da Aviação Civil, atual ANAC \\
\hline ICAO & - & International Civil Aviation Organization \\
\hline IFR & - & Instrument Flight Rules \\
\hline INT & - & Intent Knowledge \\
\hline LDR & - & Limited Dynamic Resectorization (DR) \\
\hline MIT & - & Massachusetts Institute of Technology \\
\hline
\end{tabular}




\begin{tabular}{|c|c|c|}
\hline NASA & - & National Aeronautics and Space Administration \\
\hline NASA-TLX & - & NASA Task Load Index \\
\hline NBR & - & Aircraft Neighboring Conflict \\
\hline PRC & - & Conflict Near Sector Boundary \\
\hline PRX & - & Aircraft Proximity to Sector Boundary \\
\hline RAMS & - & Reorganized ATC Mathematical Simulator \\
\hline RD & - & Re-setorização Dinâmica \\
\hline RDI & - & Re-setorização Dinâmica (RD) Irrestrita \\
\hline RDL & - & Re-setorização Dinâmica (RD) Limitada \\
\hline RVSM & - & Reduced Vertical Separation Minimum \\
\hline SBGR & - & Aeroporto Internacional de São Paulo - Guarulhos \\
\hline SBKP & - & Aeroporto Internacional de Viracopos \\
\hline SBMT & - & Aeroporto Campo de Marte \\
\hline SBSP & - & Aeroporto Internacional de São Paulo - Congonhas \\
\hline SID & - & Standard Instrument Departure \\
\hline STAR & - & Standard Arrival Route \\
\hline STR & - & Airspace Structure \\
\hline SUA & - & Special Use Airspace \\
\hline TMA & - & Terminal Movement Area \\
\hline TWR & - & Tower Control \\
\hline UDR & - & Unrestrited Dynamic Resectorization (DR) \\
\hline UTA & - & Upper Traffic Area \\
\hline VDF & - & Variance in Directions of Flight \\
\hline VFR & - & Visual Flight Rules \\
\hline VHF & - & Very High Frequency \\
\hline VAC & - & Visual Approach Chart \\
\hline
\end{tabular}




\section{Introduçãa}

\subsection{Motivação}

No mundo atual, onde cada vez mais existe a busca de agilidade de locomoção, tanto para transporte de pessoas como para transporte de carga, a demanda por transporte aéreo vem aumentando significativamente. De acordo com pesquisas divulgadas pela ICAO International Civil Aviation Organization (ICAO, 2000), entre 1960 e 1999, o transporte aéreo de passageiros cresceu 25 vezes em termos de passageiros transportados por quilômetro. No mesmo período, o transporte de carga cresceu 50 vezes em termos de toneladas transportadas por quilômetro. Tudo isso representou um aumento de $300 \%$ no número de pousos e decolagens para o mesmo período.

No caso do Brasil, especificamente na Área de Controle Terminal (TMA - Terminal Movement Area) de São Paulo, uma das regiões do país com um dos maiores fluxos de aeronaves, em 15 anos, no período entre 1988 e 2003, houve um aumento de 62\% no número de vôos, conforme apresentado na Figura 1 (DECEA, 2006). Essa área também é conhecida por TMA São Paulo ou, de forma mais simplificada, por TMA-SP.

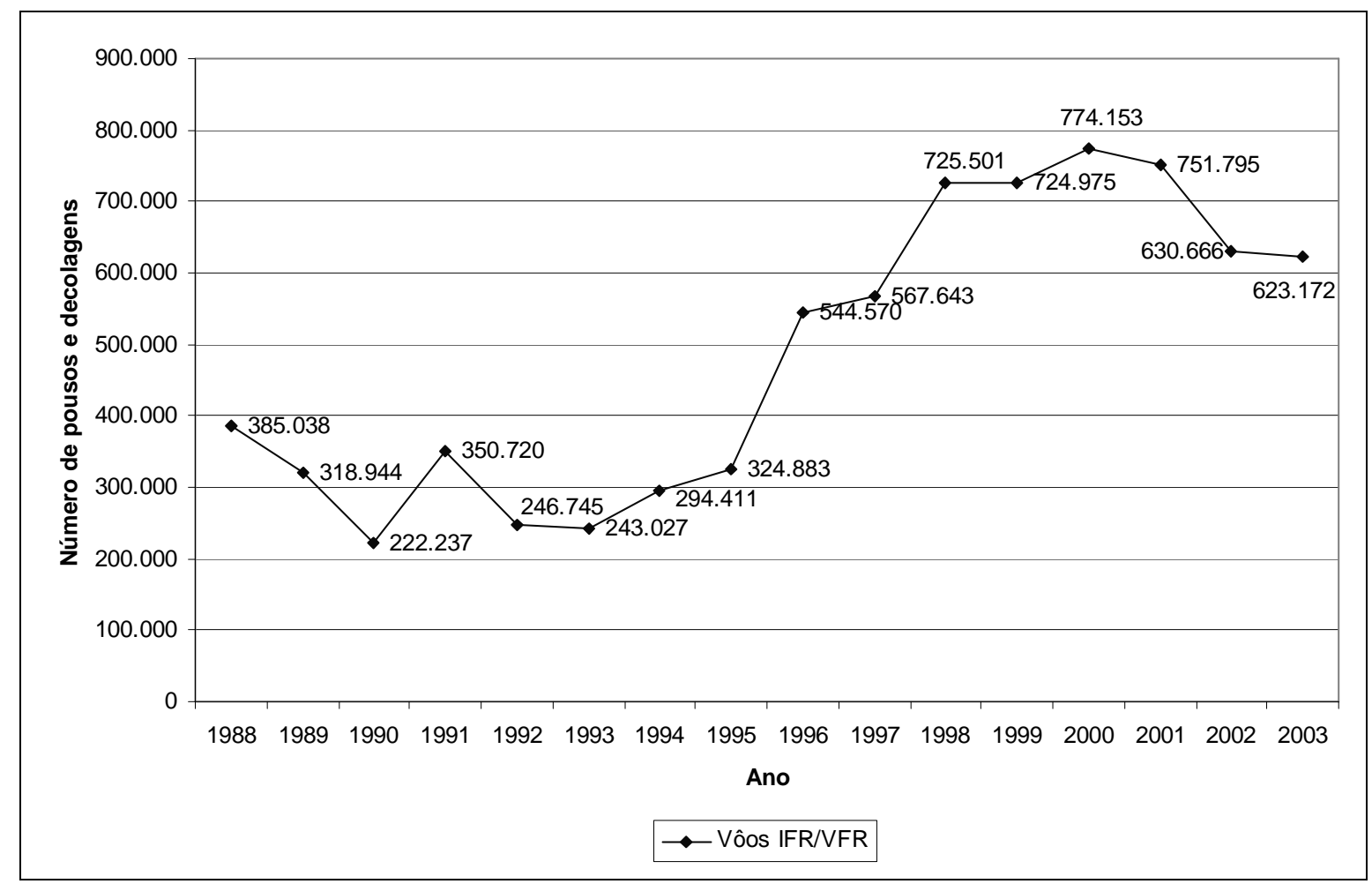

Figura 1 - Evolução do tráfego aéreo na TMA São Paulo, no período de 1988 a 2003 (DECEA, 2006). 
Olhando para o futuro do mercado regular ${ }^{1}$ brasileiro, é esperado até 2025 um crescimento em termos de pouso e decolagem de $6,37 \%$ ao ano, considerando os vôos nacionais, e de 4,95\% ao ano, considerando os vôos internacionais. Isso representa um aumento de $223 \%$ no número de vôos nacionais e de $221 \%$ no número de vôos internacionais em relação ao ano de 2006 , considerando os pousos e as decolagens (IAC, 2005a).

Mesmo em um cenário com crescente demanda pelo uso do espaço aéreo, o Brasil vem apresentando eficiência no controle e prevenção de acidentes ao logo dos anos. Conforme a Figura 2, o número de acidentes da aviação civil no espaço aéreo brasileiro vem diminuindo ao longo do tempo, passando de 408, em 1979, para 66, em 2006 (ANAC, 2007). Isso representou uma redução de $520 \%$ no número de acidentes em 27 anos.

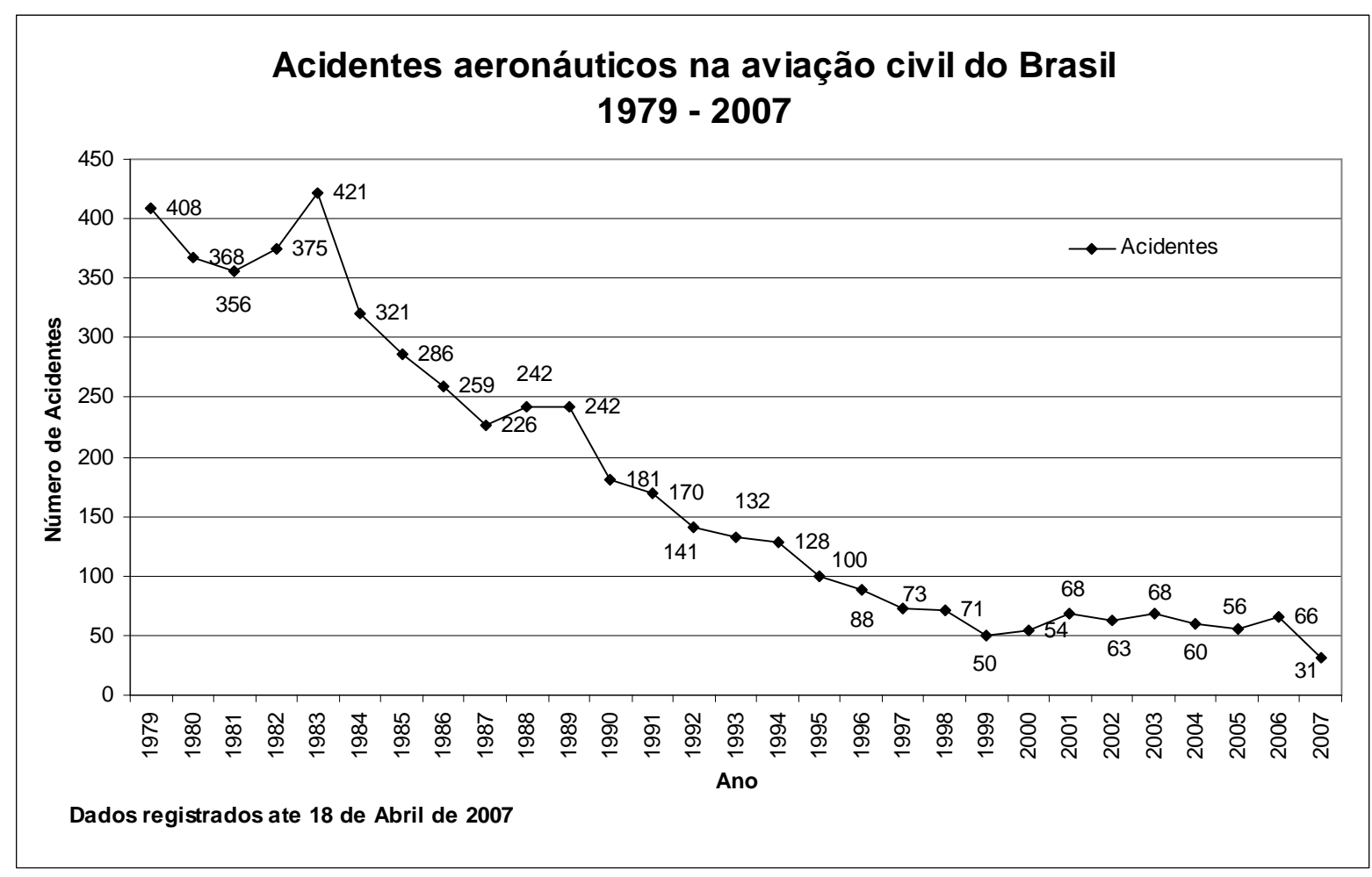

Figura 2 - Evolução dos acidentes na aviação civil no Brasil (ANAC, 2007).

Em contrapartida, conforme a Figura 3, a frota de aeronaves no Brasil saltou de 7.494, em 1990, para 11.182, em abril de 2007 (ANAC, 2007).

\footnotetext{
${ }^{1}$ Mercado regular é representado pelas empresas aéreas que prestam serviços de transporte aéreo para a sociedade, em que os horários dos vôos são regulares, ou seja, previamente estabelecidos.
} 


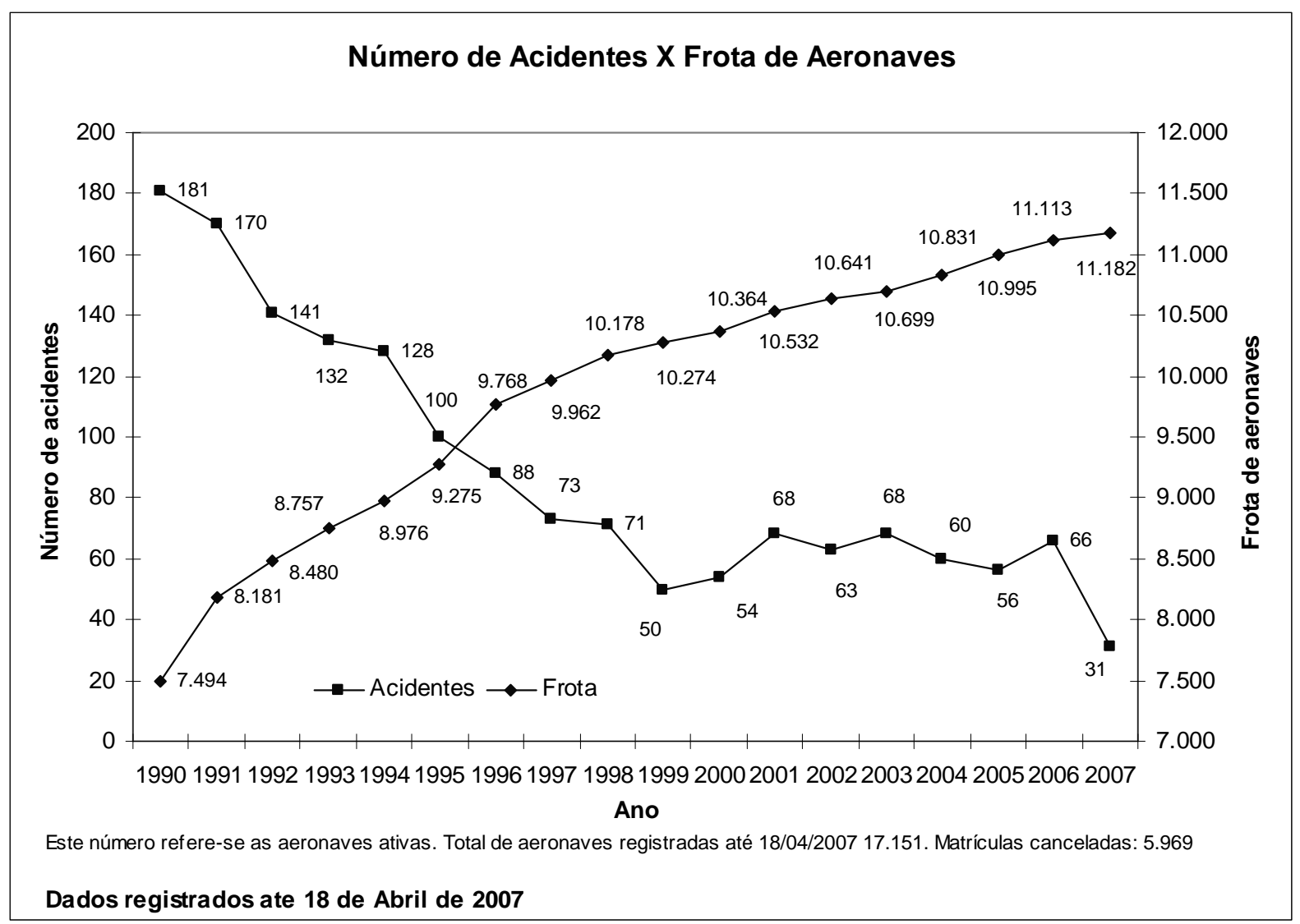

Figura 3 - Acidentes aeronáuticos na aviação civil do Brasil e evolução da frota (ANAC, 2007).

Em particular, mesmo com a estatística de redução em 520\% no número de acidentes em 27 anos, um único acidente pode provocar um desconforto geral na sociedade, como o recente acidente relativo ao choque entre o Boeing 737-800 da Gol (vôo número 1907) e a aeronave Legacy, em 29 de Setembro de 2006, que matou 154 pessoas (FARIAS NETO, 2007). A Figura 4 apresenta com mais detalhe, a partir de 1998, o número de acidentes aéreos da aviação civil brasileira, associado ao número de fatalidades, dada a evolução da frota de aeronaves no Brasil (ANAC, 2007). O acidente do Boeing 737-800 com a aeronave Legacy, em 2006, gerou um pico de 208 fatalidades na estatística de acidentes com fatalidades na aviação brasileira. 


\section{ACIDENTES NA AVIACC̃̃O CIVIL BRASILEIRA ÚLTIMOS DEZ ANOS}

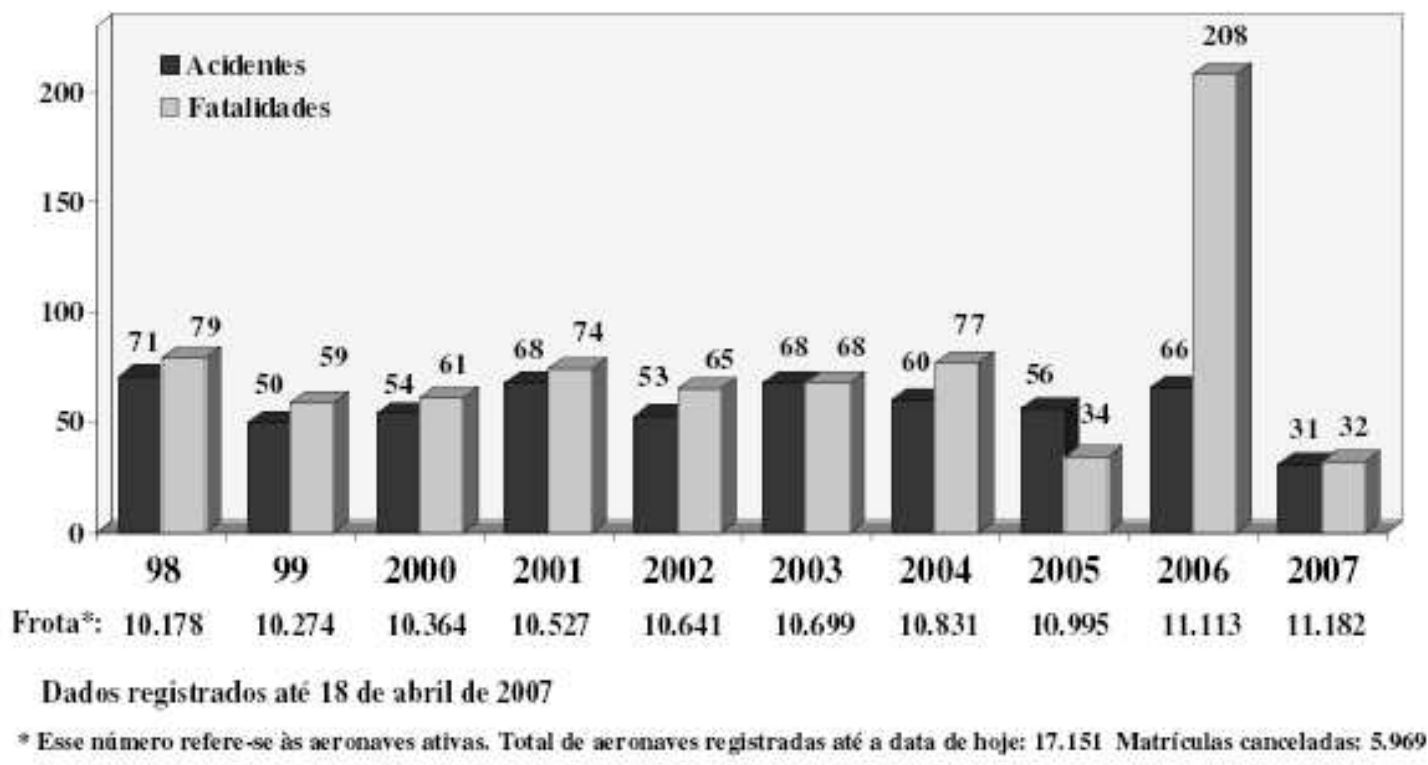

Fonte: DIPAA

Figura 4 - Acidentes e fatalidades na aviação civil brasileira (ANAC, 2007).

No centro de todo esse crescimento e da Gestão do Tráfego Aéreo (ATM - Air Traffic Management), encontra-se o Controle de Tráfego Aéreo (ATC - Air Traffic Control), que busca garantir segurança na operação de tráfego aéreo, sem por em riscos as vidas dos passageiros, tripulantes e todas as pessoas envolvidas neste cenário. Uma das peças fundamentais no ATC é o controlador de tráfego aéreo, responsável por prestar serviços de controle e monitoramento das aeronaves no espaço aéreo.

Quanto maior o número de aeronaves no espaço aéreo, maior será a densidade de aviões e, conseqüentemente, maior será a atenção que cada controlador terá que ter no seu trabalho para prevenir e gerenciar conflitos. Logo, a crescente demanda pelo transporte aéreo vem provocando um aumento na carga de trabalho do controlador de tráfego aéreo que, por vezes, realiza suas tarefas sob forte tensão, ficando potencialmente no limite para cometer algum erro.

Um caso verídico de um acidente que provocou a morte de 3 pessoas foi o do Lufthansa, no Rio de Janeiro, em 26 de Julho de 1979. Segue relato da comunicação desse acidente, retirado do livro "Choque de Gestão: do Vôo 1907 ao Apagão Aéreo no Brasil”, segundo o chefe do radar da época (FARIAS NETO, 2007; ASN, 2007): 
“Controle Rio - Lufthansa 335 clear to take off (Lufthansa 335 está livre a sua decolagem).

Lufthansa 335 - Roger (Ok).

Lufthansa 335 - We will climb level 100 after taking off (One zero zero, em um pesado sotaque alemão) (Nós iremos subir para o nível 100 depois da decolagem).

Controle Rio - Roger (Ok) [...]

Neste instante, um Boeing 737 da Varig, que chegava ao Rio, iniciou sua "perna básica" preparando-se para o pouso.

Controle Rio - Lufthansa 335, turn left. There is a traffic just in front of you. Climb to level 80. I gonna call you later (Lufthansa 335 faça curva à esquerda, existe tráfego a sua frente. Suba para o nível 80. Eu irei chamá-lo mais tarde).

Provavelmente devido ao cansaço, o controlador se esqueceu de imediatamente retirar o Lufthansa da rota de colisão com a Serra dos Órgãos, mas isso não seria nenhum problema. A margem de risco para o Lufthansa era mínima, pois a distância entre ele e a montanha era imensa naquele instante. Entretanto a sucessão de fatalidade que antecede um acidente aéreo foi completada pela entrada na fonia de mais uma aeronave, argentina, pilotada por uma mulher.

Anv. Argentina - Control Rio.

Controle Rio - Buenas noches señora (boa noite senhora).

Anv. Argentina - Buenas noches control Rio (boa noite controle Rio).

Controle Rio - Su voz es mui hermosa (sua voz é muito harmoniosa).

Este idílio consumiu um tempo precioso e colocou a margem de risco do Lufthansa "nas alturas". Inexplicavelmente, o controlador solicitou uma razão de subida de 3.000 pés por minuto, impossível para um Boeing 707 carregado de carga. Inexplicavelmente o piloto concordou.

Controle Rio - Nuestra pista 32 está a su disposición, señora (Nossa pista 32 está a disposição, senhora).

Anv. Argentina - Muchas gracias control Rio (Obrigado controle Rio).

Control Rio - Lufthansa 335 turn right, right now! - Roger (Lufthansa 335, vire a direita, agora!). 
Naquele instante o controlador acordou da letargia, mas já era tarde...

Controle Rio - Lufthansa 335, this is Controle Rio (Lufthansa 335, aqui é controle Rio).

\section{Controle Rio - Lufthansa!}

Controle Rio - Meu Deus, tem um incêndio no quadrante da refinaria de Duque de Caxias!

\section{Controle Rio - Lufthansa!}

Controle Rio - Lufthansa!

Controle Rio - Meu Deus! Eles bateram, eles bateram!"

Segundo (ASN, 2007), uma das variáveis que influenciaram a causa do acidente do Lufthansa no Rio de Janeiro foi a chegada de tráfego aéreo na parte sul do setor controlado pelo controlador que estava controlando o Lufthansa. Um aumento do tráfego aéreo controlado por um controlador influenciou na causa do acidente, gerando vitimas fatais.

As buscas por mecanismos que garantam a segurança do Controle de Tráfego Aéreo, dando condições aos controladores de monitorar e controlar as aeronaves no espaço aéreo, vêm sendo abordadas não só pelos órgãos responsáveis pelo Gerenciamento do Tráfego Aéreo, mas também por vários pesquisadores das universidades e órgãos científicos do mundo (KOPARDEKAR, 2003; MASALONIS, 2003; RIZZI, 2003). Este trabalho de investigação científica é uma das vertentes dessas pesquisas.

\subsection{Objetivo}

Atualmente o espaço aéreo é dividido em setores estáticos nos quais um ou mais controladores de tráfego aéreo são responsáveis pelo seu controle. A falta de flexibilidade, inerente da condição estática de divisão do espaço aéreo em setores, não garante uma otimização do controle do espaço aéreo nem de sua utilização, pois não existe necessariamente uma equalização do número de aeronaves distribuídas pelos diversos setores durante todo o tempo (WYNDEMERE, 1997).

Buscar uma forma de "setorização" do espaço de maneira dinâmica pode levar a uma otimização do controle dos setores do espaço aéreo e a uma diminuição da sobrecarrega de 
trabalho dos controladores de tráfego aéreo, além de diminuir, como consequiência, atrasos que por ventura possam ocorrer em virtude da falta de otimização de uso do espaço aéreo e da sobrecarga de trabalho dos controladores. Entende-se por "Re-setorização" Dinâmica (DR Dynamic Resectorization), neste caso, a capacidade de redefinição das regiões de controle do espaço aéreo durante o tempo, visando à melhoria da qualidade do controle de tráfego aéreo e à diminuição dos riscos da ocorrência de incidentes ou acidentes, tendo como base alguns pressupostos estabelecidos (WILHELMSEN et al., 1999a).

O objetivo deste trabalho de pesquisa tem como ponto principal investigar o uso da Resetorização Dinâmica no controle do espaço aéreo e mostrar como ela pode influenciar na carga de trabalho dos controladores do tráfego aéreo ao longo de um dia de trabalho.

Como estudo de caso pretende-se utilizar parte do espaço aéreo brasileiro com maior tráfego de aeronaves, referente ao Controle de Aproximação (APP - Approach Control), no caso a Área de Controle Terminal de São Paulo (TMA-SP), valendo-se de informações do tráfego de aeronaves durante um dia típico e um dia com alta demanda de aeronaves.

Baseado na configuração dos setores do espaço aéreo e em informações do Controle de Aproximação de São Paulo (APP-SP) pretende-se criar configurações alternativas do espaço aéreo da TMA-SP, tanto para um dia atual típico e com alta densidade de aeronaves, como para um dia futuro, considerando a projeção do tráfego aéreo para 2015.

Deseja-se simular computacionalmente o tráfego aéreo da TMA-SP a fim de se analisar o impacto do uso da re-setorização dinâmica na carga de trabalho de cada controlador de tráfego aéreo com base em cenários reais.

\subsection{Estrutura do Trabalho}

Esta dissertação está organizada em seis capítulos, descritos a seguir de uma forma sucinta.

O Capítulo 1 apresenta a motivação deste trabalho de pesquisa e seu objetivo, bem como a forma com ele está organizado.

O Capítulo 2 tem por objetivo contextualizar o trabalho dentro do cenário de controle do tráfego aéreo. São introduzidos os conceitos a respeito da divisão do espaço aéreo, do controle do espaço aéreo, bem como o papel desempenhado pelo controlador de tráfego aéreo. 
No Capítulo 3 é apresentado o conceito da Re-setorização Dinâmica e seis casos de uso nos quais ela pode ser aplicada. Em cada caso de uso, além de serem introduzidos seus princípios, são mostrados exemplos reais de suas aplicações.

O Capítulo 4 contém a metodologia presente neste trabalho de pesquisa. Nele também é contextualizado o software utilizado nas simulações computacionais, é apresentada qual a região do espaço aéreo escolhida para análise nesta investigação científica e são formalizados os estudos de caso apresentados neste trabalho.

No Capítulo 5 são analisados os resultados das simulações computacionais realizadas neste trabalho, com base nos modelos apresentados no Capítulo 4.

O Capítulo 6 apresenta as principais conclusões, recomendações e considerações finais decorrentes deste trabalho de pesquisa, assim como propostas para trabalhos futuros.

Ainda, encontram-se presentes neste trabalho, um glossário com alguns dos principais termos ou conceitos relacionados com esta pesquisa, e dois anexos com gráficos detalhados com resultados de simulações computacionais realizadas para esta pesquisa. 


\section{Gerenciamento do Tráfego Aéreo}

Neste capítulo é abordado o conceito envolvido com um sistema de Gerenciamento do Tráfego Aéreo (ATM - Air Traffic Management). O Gerenciamento do Tráfego Aéreo é a habilidade para se prover Serviço de Navegação para certo volume de tráfego aéreo, com um alto nível de segurança (BOEING, 1997). Esse capítulo apresenta, inicialmente, uma contextualização do tráfego aéreo, passando pela definição dos principais componentes do ATM e finalizando com uma abordagem sobre o trabalho realizado pelo Controlador de Tráfego Aéreo.

\subsection{Introdução}

Inicialmente, próximo à década 30 , quando as aeronaves eram relativamente lentas e a maioria dos vôos ocorria durante o dia, não existia o complexo sistema de gerenciamento do tráfego aéreo conhecido atualmente. As aeronaves voavam baseados em procedimentos conhecidos como Regras de Vôo Visual (VFR - Visual Flight Rules).

Neste tipo de vôo é necessário atender a algumas regras, como manter uma distância de referência com o solo ou com a água, de modo que as formações abaixo do nível de vôo não obstruam mais que a metade da área de visão do piloto. Para esse procedimento é necessário que existam boas condições visuais em que o próprio piloto é o seu controlador de vôo (SALLES, 2006).

Com o passar do tempo, as aeronaves foram agregando mais tecnologia, ganharam maior velocidade, passaram a comportar mais passageiros e novos instrumentos de navegação, e a demanda por transporte aéreo de carga e passageiro aumentou consideravelmente.

Para atender a essa demanda crescente era preciso que as aeronaves não se restringissem a voar apenas sob boas condições meteorológicas, ou seja, as regras de vôo baseadas em boas condições visuais não mais atendiam ao novo tráfego que estava surgindo. Criaram-se, então, novas regras conhecidas como Regras de Vôo por Instrumentos (IFR - Instrument Flight Rules). Essas regras passaram a permitir que as aeronaves executassem todas as fases de vôo 
em condições meteorológicas adversas, pois elas passaram a contar com o auxílio de instrumentos e serviços de tráfego aéreo.

Com essas novas regras o piloto passou a desfrutar de serviços para orientá-lo durante o vôo, deixando de ser o seu próprio controlador. Surgiu, assim, uma nova figura no ATM, o “controlador de vôo" ou "controlador de tráfego aéreo". Responsável por controlar o espaço aéreo e servir de suporte para os pilotos, o controlador de tráfego aéreo exerce importância fundamental no controle de tráfego aéreo.

Hoje, com o volume de aeronaves voando no espaço sob condições de tempo adversas, os serviços de tráfego aéreo (ATS - Air Traffic Services) são essenciais. Eles são divididos basicamente em três categorias: Controle de Tráfego Aéreo (ATC - Air Traffic Control), que é o serviço prestado pelos controladores responsáveis por controlar e monitorar todo o espaço aéreo; Serviço de Informação ao Vôo (FIS - Flight Information Service), responsável por fornecer informações que auxiliam os pilotos na condução do vôo, como por exemplo, informações das condições meteorológicas, auxílio à navegação e serviço de alteração do tráfego aéreo; e Serviço de Alerta (AS - Alert Service), que é prestado a toda a aeronave que voe sob IFR ou sob VFR, exceto aquelas aeronaves cujos vôos não tenham sido notificados ao ATS e as aeronaves que se saiba ou se suspeite de que estejam sendo objetos de interferência ilícita (MCA 53-1, 2000).

Uma observação importante é que o ATS não isenta o piloto em comando de suas responsabilidades. Ele é responsável por tomar qualquer decisão no tocante a alterações no plano de vôo e adotar outras medidas que lhe parecerem convenientes para garantir maior segurança ao vôo (MCA 53-1, 2000).

Basicamente, os vôos são divididos em oito fases de operação relacionadas com o controle de tráfego aéreo (BOEING, 1997), conforme ilustra a Figura 5. 


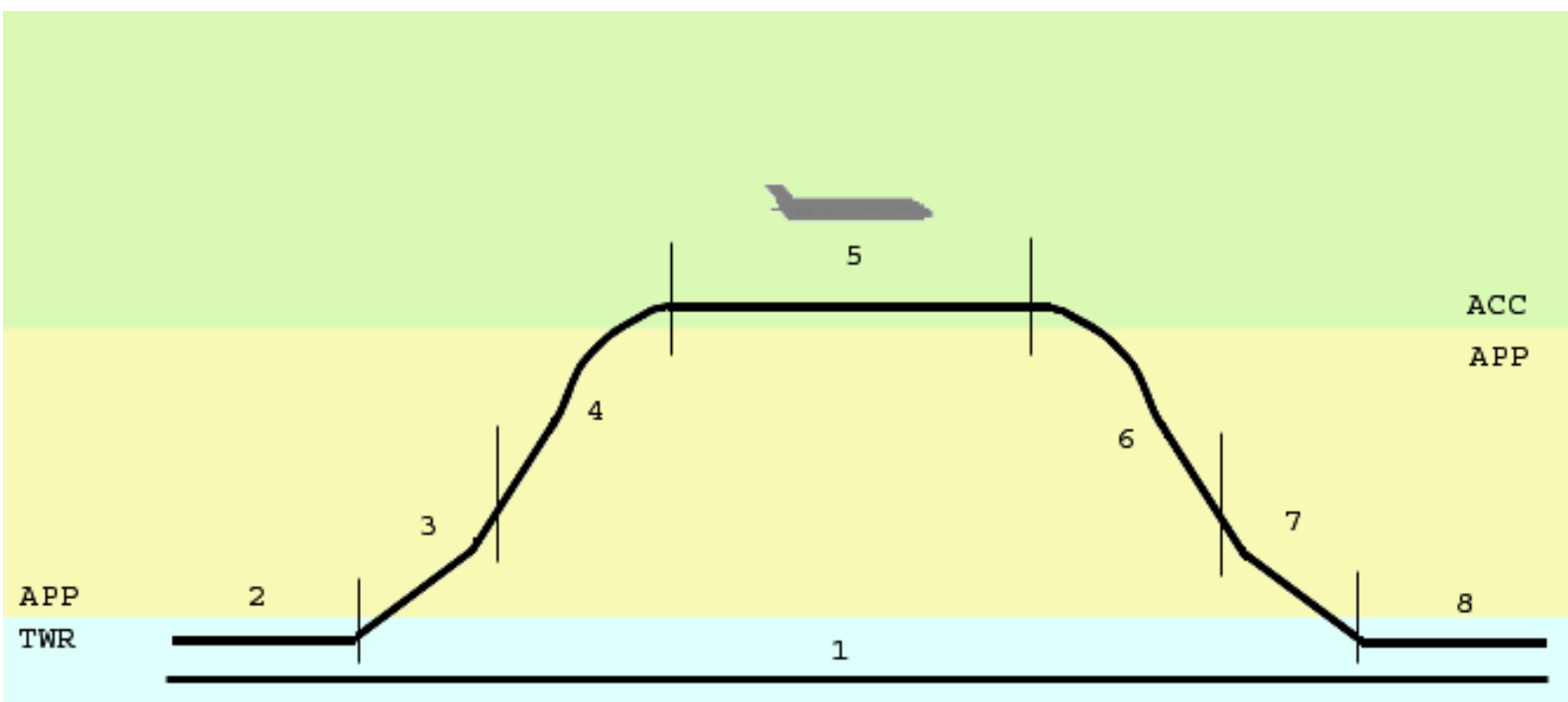

1-Plano de vôo 2-Taxiamento e deslocamento em solo na decolagem

3-Subida inicial

5-Cruzeiro

7-Aproximação final
4-Saída da área terminal

6-Aproximação de área terminal

8- Taxiamento e deslocamento em solo no pouso

Figura 5 - Fase de operação de vôo.

A seguir são descritas as oito fases de vôo apresentadas na Figura 5:

- A fase 1 é o plano de vôo que contém informações relacionadas com um vôo planejado de uma aeronave ou com parte do mesmo. Ele tem início antes que a aeronave entre na pista. Este plano de vôo deve ser submetido à aprovação das autoridades competentes (ICA 100-11, 2000);

- A fase 2 é a fase de taxiamento na qual a aeronave se move em solo, preparando para a decolagem. Nesta fase a aeronave se descola da posição de embarque e se posiciona na cabeceira da pista, aguardando a permissão para decolar. O controle da aeronave está, nesta fase, sob responsabilidade da Torre de Controle (TWR - Tower Control);

- A fase 3 é a fase de subida inicial. Nesta fase a aeronave decola até certa altitude, quando sai da jurisdição da TWR, passando a ser controlada pelo Controle de Aproximação (APP - Approach Control);

- A fase 4 é a fase de saída da área terminal. A aeronave continua em ascensão para atingir o nível de cruzeiro. Nesta fase, existe uma transição do setor responsável pelo 
controle da aeronave. Ela sai da responsabilidade do Controle de Aproximação (APP), passando para a responsabilidade do Controle de Área (ACC - Area Control Center);

- A fase 5 é a fase de cruzeiro. Esta é a fase do vôo que pode ter duração entre poucos minutos até horas, dependendo da distância entre o aeroporto origem e o aeroporto destino. Nesta fase a aeronave nivela seu vôo, atingindo uma velocidade estável de cruzeiro;

- A fase 6 é denominada de fase de aproximação de área terminal. Nesta fase a aeronave inicia a descida, passando a não ser mais controlada pelo ACC, voltando para o controle de um APP;

- A fase 7 é a fase de aproximação final. Nesta fase, para os vôos IFR, a aeronave se aproxima para pouso sob procedimentos de instrumentos. Aqui existe a transição do controle da aeronave do APP para a TWR; e

- A fase 8 é a fase de taxiamento de aeronave e deslocamento em solo após o pouso. Nesta última fase a aeronave pousa no aeroporto de destino e se desloca até a área de desembarque de passageiros ou de carga. A aeronave está, neste momento, sob o controle da TWR.

\subsection{O Espaço Aéreo}

O espaço aéreo de um determinado país é aquele sobre o seu território nacional, incluindo o espaço sobre o alto mar delimitado por intermédio de um acordo regional de navegação aérea pelo Conselho da ICAO (SALLES, 2006).

O espaço aéreo sob jurisdição do Brasil é aquele que se superpõe ao seu território nacional, incluindo as águas territoriais e jurisdicionais, e também o que avança na direção do alto mar, pois assim está estabelecido em acordo regional de navegação aérea, ratificado pelo Conselho da ICAO (MCA 53-1, 2000). A Figura 6 ilustra o espaço aéreo brasileiro aqui descrito. 


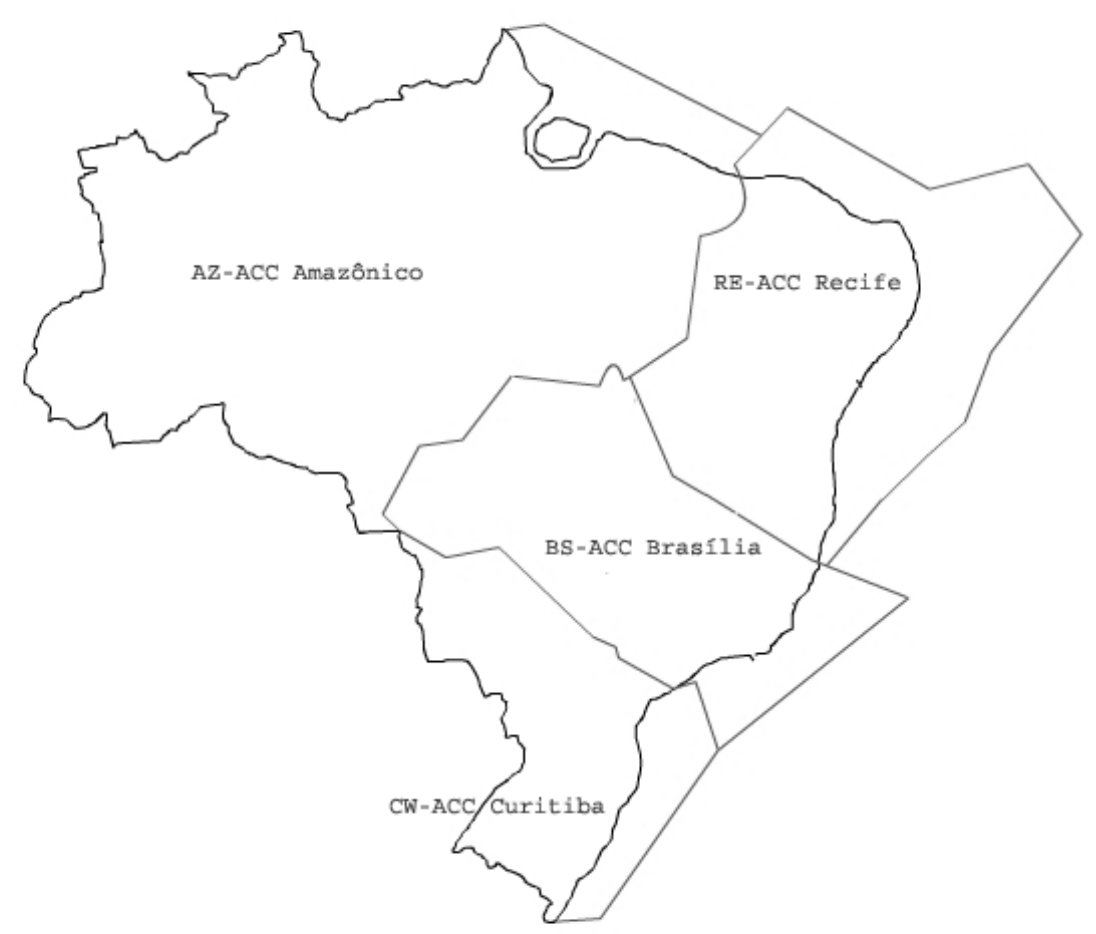

Figura 6 - Espaço aéreo brasileiro (NCAG 2, 2005).

O espaço aéreo brasileiro pode ser dividido em 3 categorias (SALLES, 2006; FAA, 2006), apresentado a seguir e ilustrado na Figura 7:

- Espaços Aéreos não Controlados: são os espaços aéreos onde não é prestado o serviço de controle de tráfego aéreo (ATC - Air Traffic Control). Neste caso, os próprios pilotos são responsáveis pela navegação de suas aeronaves;

- Espaços Aéreos Controlados: são os espaços aéreos onde é prestado o serviço de controle de tráfego aéreo (ATC). Maiores detalhes são apresentados no item 2.3 deste trabalho. Esta parte do espaço aéreo é formada por:

1. Áreas Superiores de Tráfego (UTA - Upper Traffic Area): compreendem as aerovias superiores e outras partes do espaço aéreo superior;

2. Áreas de Controle de Tráfego (CTA - Control Traffic Area): compreendem aerovias inferiores e outras partes do espaço aéreo inferior; 
3. Áreas de Controle Terminal (TMA - Terminal Movement Area): áreas de controle situadas geralmente na confluência de rotas suportados pelo ATS e nas imediações de um ou mais aeródromos. Essas áreas têm configuração variável, indicadas nas cartas de vôo e, no Brasil, nos manuais publicados pela DECEA - Departamento de Controle do Espaço Aéreo;

4. Zonas de Controle de Tráfego (CTR - Control Traffic Zone): área de controle situada nas imediações de um aeródromo, com configuração variável, indicada nas cartas de vôo e, no Brasil, nos manuais publicados pela DECEA; $\mathrm{e}$

5. Zona de Tráfego de Aeródromo (ATZ - Aerodrome Traffic Zone): consiste da área do espaço que circunda todo o circuito de tráfego de um aeródromo. Sua configuração é variável, dependendo de cada aeródromo. Quando o circuito é diferente do padrão, é definido nas Cartas de Aproximação Visual (VAC - Visual Approach Charts).

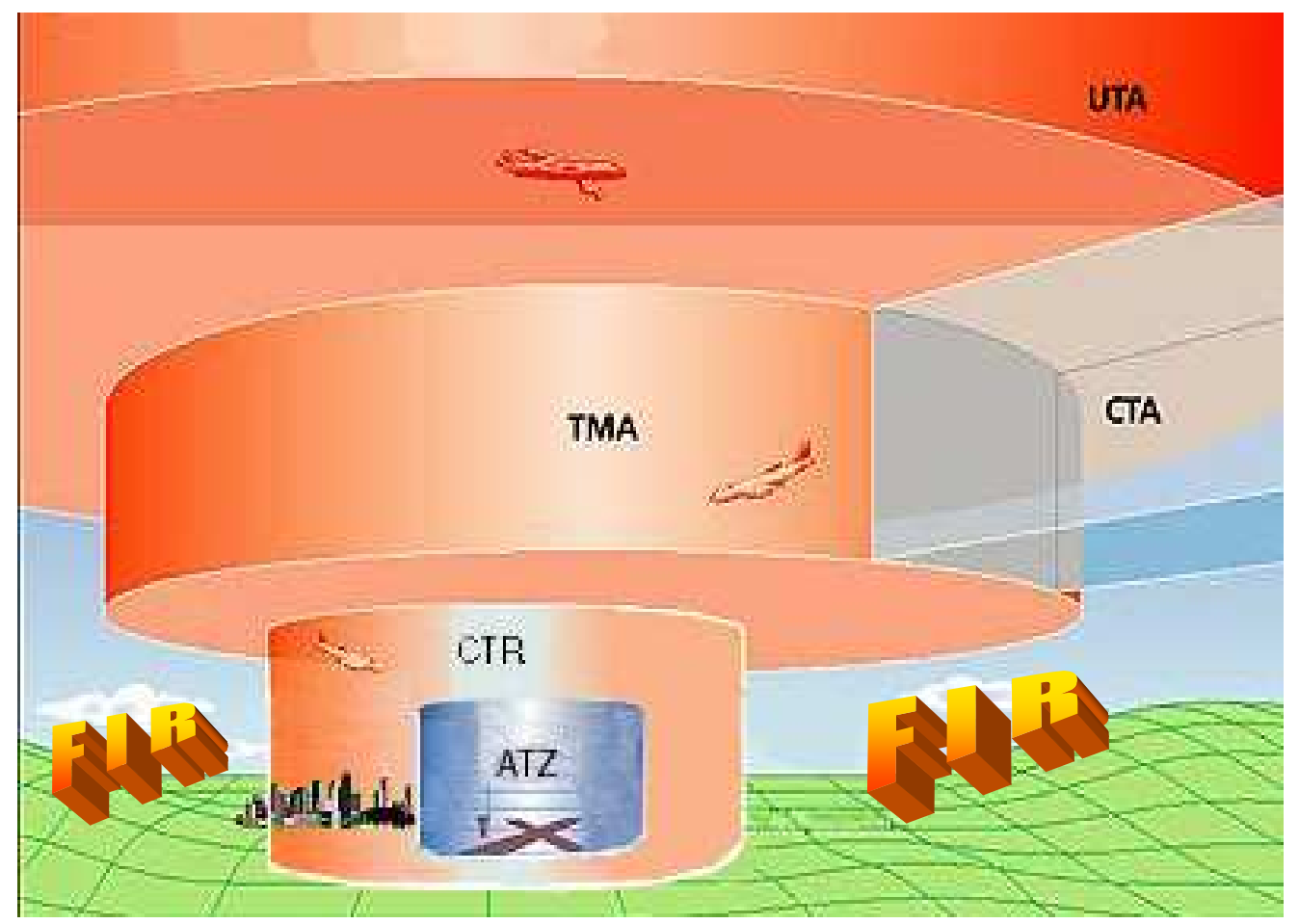

Figura 7 - Divisão do espaço aéreo².

\footnotetext{
${ }^{2}$ Esta figura foi obtida nas entrevistas realizadas com controladores de tráfego aéreo, adaptada para este trabalho, não tendo sido possível identificar sua autoria até o término deste trabalho.
} 
- Espaços Aéreos Condicionados: os espaços aéreos condicionados são os espaços aéreos restritos à circulação aérea geral, de dimensões definidas. Os limites desses espaços aéreos são indicados nas cartas aeronáuticas e, no Brasil, nos manuais do DECEA, podendo ser estabelecido em caráter temporário ou permanente, sendo formado por:

1. Áreas Proibidas: o vôo não é permitido, como por exemplo, em áreas próximas a refinarias, fábrica de explosivos, usinas hidroelétricas, áreas de segurança nacional, etc.;

2. Área Restrita: o vôo é permitido sob condições preestabelecidas, como por exemplo, em áreas onde ocorram lançamento de paraquedistas, exercício de tiro, lançamento de foguetes, etc.; e

3. Área Perigosa: corresponde ao espaço aéreo no qual existem riscos em potencial para a navegação aérea, como em áreas de treinamento de aeronaves civis.

A Região de Informação de Vôo (FIR - Flight Information Region) é a região do espaço na qual são prestadas os Serviços de Informação ao Vôo e os Serviços de Alerta. A FIR, juntamente com os Espaços Aéreo Controlados, forma o Espaço Aéreo onde são prestados os Serviços de Tráfego Aéreo (ATS - Air Traffic Service).

Em termos de limite vertical, o espaço aéreo brasileiro é divido em (MCA 53-1, 2000):

- Espaço Aéreo Superior: é o espaço aéreo que apresenta as seguintes características:

1. Limite vertical superior: ilimitado;

2. Limite vertical inferior: FL $245^{3}$, exclusive; e

3. Limites laterais: indicados nas Cartas de Rota (ERC - En Route Charts).

- Espaço Aéreo Inferior: esse espaço apresenta as seguintes características:

1. Limite vertical superior: FL245, inclusive;

2. Limite vertical inferior: solo ou água; e

3. Limites laterais: indicados nas Cartas de Rota (ERC).

\footnotetext{
${ }^{3}$ FL (Flight Level) é o valor da altitude da aeronave, em pés (ft), desprezando os dois últimos zeros, em intervalos de 500 pés. Assim, para uma altitude igual a 4500 ft, o nível de vôo é 045 (1 pé equivale a 30,48cm).
} 


\subsection{O Controle do Tráfego Aéreo}

O Controle de Tráfego Aéreo (ATC - Air Traffic Control), responsável por gerenciar e controlar todo o tráfego de aeronaves no espaço e em terra, busca garantir a segurança do transporte aéreo, atendendo a sua demanda.

O espaço aéreo é formado por blocos que se combinam como em um "quebra-cabeça", constituindo as áreas de controle. Esses blocos são chamados de setores nos quais um ou mais controladores de tráfego aéreo são responsáveis por planejar, monitorar e controlar o fluxo de aeronaves no espaço.

De forma macroscópica, o ATC fornece os seguintes serviços (ICA 100-12, 2006):

- Monitora a aeronave em solo, dando autorização para pouso e decolagem, serviço esse denominado Serviço de Controle de Aeródromo;

- Monitora o tráfego de aproximação/decolagem de aeronaves para/de aeroportos. Esse serviço é conhecido como Serviço de Controle de Aproximação; e

- Monitora o tráfego de navegação em rota das aeronaves entre aeroportos, denominado Serviço de Controle de Área.

Esses três serviços são prestados por órgãos específicos de controle, dentro do ATC, a saber: Controle de Aeródromo (TWR - Tower Control), Controle de Aproximação (APP Approach Control) e Centro de Controle de Área (ACC - Area Control Center), conforme indicado na Tabela 1 (SALLES, 2006).

Tabela 1 - Zonas de controle do ATC.

\begin{tabular}{|c|c|c|}
\hline Órgão de Controle & Sigla & Espaço que Controla \\
\hline Controle de Aeródromo & TWR & ATZ \\
\hline Controle de Aproximação & APP & CTR/TMA \\
\hline Centro de Controle de Área & ACC & CTA/UTA \\
\hline
\end{tabular}




\subsubsection{Controle de Aeródromo - TWR}

O TWR é responsável por controlar a Zona de Tráfego de Aeródromo. Este serviço é prestado pelos controladores de tráfego aéreo que estão na Torre de Controle de cada aeródromo. Esses controladores têm por finalidade gerenciar o fluxo de aeronaves na região do aeródromo, em vôo ou no solo, emitindo instruções, autorizações e informações para os pilotos em vôo, em operação de taxiamento ou em operações de pouso e decolagem. Os dados informados são, basicamente, a direção e a velocidade do vento, a pista a ser utilizada, a temperatura local, a pressão atmosférica e as informações meteorológicas em geral.

O controle fornecido pelo TWR engloba duas fases de vôo de forma isolada, taxiamento/decolagem e pouso/taxiamento, além de duas fases em coordenação com o APP, correspondendo à subida inicial e aproximação final. Após a decolagem, o controlador responsável pelo TWR passa o controle da aeronave para o controlador do APP. O controlador do TWR informa ao piloto que ele deve entrar em contato com o APP em uma frequiência de rádio pré-determinada. O controlador do APP envolvido com esta aeronave que decolou, e que se encontra em seu setor, faz o aceite da transferência desta aeronave e prossegue com o seu controle. De forma análoga, no caso da operação de pouso, a aeronave é transferida de um controlador do APP para o controlador responsável pelo TWR que vai, a partir de então, auxiliá-la na sua operação de aterrissagem e taxiamento.

Para alguém não familiarizado com a área de estudo da aviação, intuitivamente o maior índice de acidentes deve ocorrer durante as fases de cruzeiro, subida inicial ou aproximação. Contudo, uma pesquisa que coletou dados dos acidentes ocorridos entre 1980 e 2001, mostra que 67,6\% desses acidentes ocorreram durante a fase de taxiamento, conforme ilustra a Figura 8 (NLR, 2003).

Portanto, apesar do serviço prestado pelo TWR parecer relativamente mais simples, quando comparado com o controle das demais áreas de tráfego aéreo, requer dos controladores um controle minucioso a fim de prevenir colisão entre as aeronaves em solo ou no ar, mantendo ordenado o fluxo de aeronaves nas imediações dos aeródromos. 


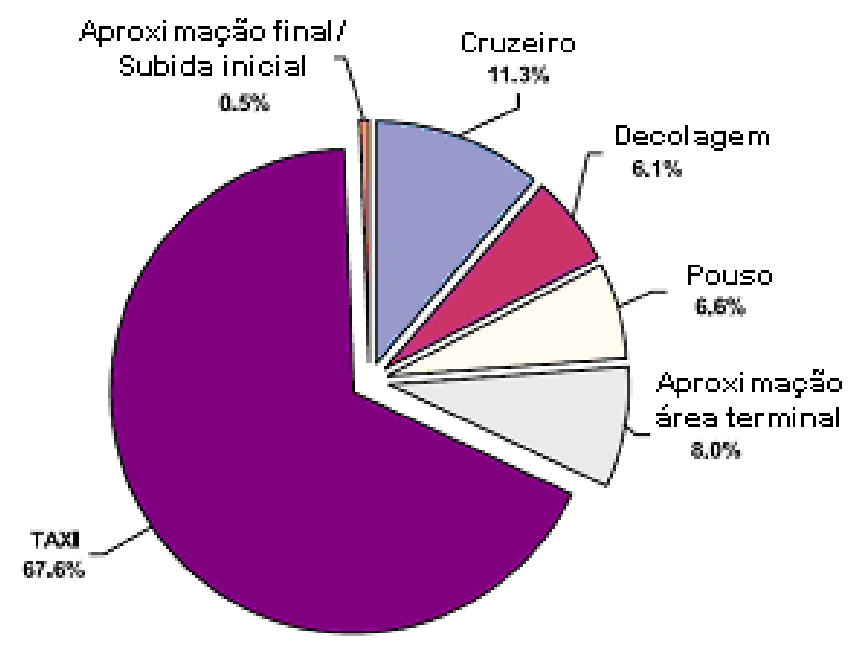

Figura 8 - Porcentagem de acidentes por fase de vôo, entre 1980 e 2001 (NLR, 2003).

\subsubsection{Controle de Aproximação - APP}

O Controle de Aproximação (APP) é responsável por controlar o espaço aéreo da Área de Controle Terminal (TMA) e da Zona de Controle de Tráfego (CTR). Apesar dos controladores não terem como visualizar de forma real as aeronaves, a sala de controle desses centros são dotadas de equipamentos e instrumentos capazes de localizar e posicionar as aeronaves no espaço. Com o auxílio desses recursos tecnológicos, os controladores do APP garantem uma separação segura entre as aeronaves, dentro do contexto do tráfego aéreo em que atuam.

O controle fornecido pelo APP engloba duas fases de vôo em conjunto com o TWR (subida inicial e aproximação final) e duas fases em conjunto com o ACC (saída da área terminal e aproximação da área terminal). Basicamente, o APP funciona como um regulador do tráfego de aeronaves no espaço aéreo da TMA. Na chegada de aeronaves, seus controladores são responsáveis por interligar as aerovias de cruzeiro com os aeroportos de destino, alinhando o fluxo das aeronaves para os controladores dos TWRs em seus respectivos aeroportos. $\mathrm{Na}$ partida de aeronaves, os controladores do APP recebem as aeronaves que decolaram de um 
dos seus aeródromos sob controle do TWR, e as encaminha para a aerovia de destino, que então passa a ficar sob a responsabilidade dos controladores do ACC.

Atualmente, o Brasil conta com treze APPs (INFRAERO, 2006). Os APPs de maior movimento são o de São Paulo, Rio de Janeiro, Curitiba, Belo Horizonte e Brasília.

\subsubsection{Centro de Controle de Área-ACC}

O Centro de Controle de Área (ACC) é responsável por controlar o espaço aéreo da Área Superior de Tráfego (UTA) e da Área de Controle de Tráfego (CTA). De uma forma geral, um ACC presta serviços de supervisão de tráfego aéreo a todas as aeronaves sob sua área de jurisdição. Estes serviços são de vigilância por radar, quando os ACCs estão equipados com este tipo de aparelho, ou via fonia de rádio, quando não existe um radar para localizar as aeronaves, como é o caso da cobertura sobre grandes áreas de oceano ou regiões remotas.

O ACC controla, em conjunto com o APP, duas fases de vôo (saída da área terminal e aproximação da área terminal), ficando a fase de cruzeiro totalmente sob sua responsabilidade. Desta forma, o ACC fecha o ciclo do controle do espaço aéreo. Os seus controladores recebem dos controladores do APP as aeronaves que partiram de um aeródromo e que vão ficar sob sua responsabilidade durante a fase de cruzeiro. Quando uma aeronave se aproximar da área terminal de destino, os controladores do ACC encaminham as aeronaves para os controladores do APP de destino que vão alinhar essas aeronaves e entregá-las para os controladores do TWR do aeródromo de destino.

Hoje o espaço aéreo brasileiro está dividido em quatro ACCs: o ACC Amazônico, responsável por controlar o tráfego aéreo da região Norte; o ACC Recife, responsável por controlar o tráfego aéreo da região Nordeste; o ACC Brasília, que controla o tráfego aéreo da região Centro-Oeste e, por fim, o ACC Curitiba, que é responsável por controlar o espaço aéreo da região Sul. A Figura 9 ilustra estes quatro ACCs, sobre o mapa do Brasil, e a forma como são divididos em setores (ACCs "setorizados"). 


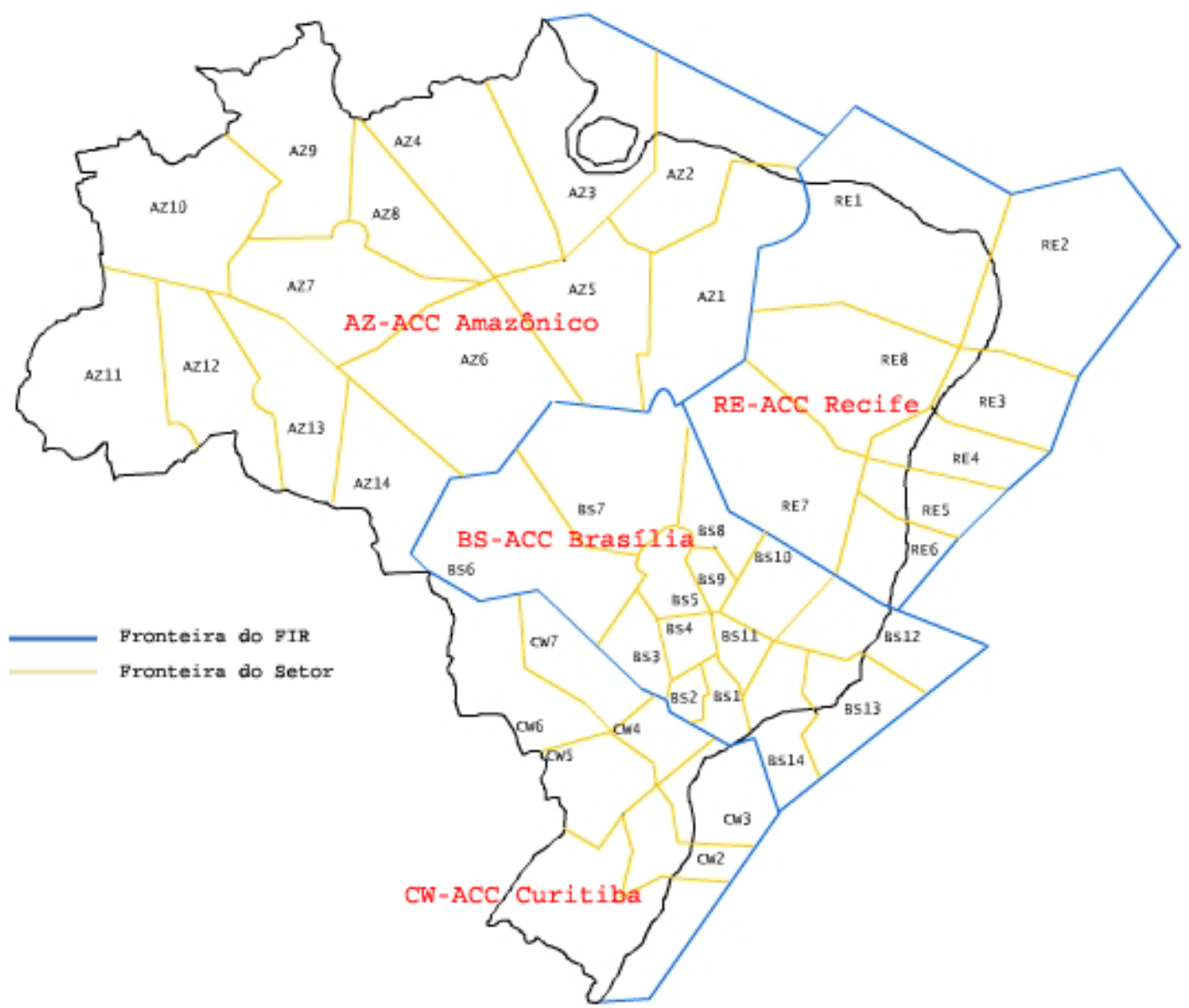

Figura 9 - Os Centros de Controle de Área (ACCs) do Brasil e seus respectivos setores (NCAG 2, 2005).

\subsection{Pontos de Atenção Durante a Setorização do Espaço Aéreo}

Nesse tópico são apresentados alguns pontos relevantes no momento de se definir as fronteiras de um determinado setor do espaço aéreo. Não apenas deve ser levado em conta o balanço do fluxo de aeronaves em cada setor, como também se deve respeitar algumas restrições (TRANDAC, DUONG, 2003; ER-1, 2001), tais que:

- Setores Convexos: não é admitido o uso de setores com formato convexo, ou seja, a rota de uma aeronave não pode passar duas vezes pelo mesmo setor, conforme mostra a Figura 10. Isso já ocorreu no passado no espaço aéreo Europeu (TRANDAC, DUONG, 2003) e causou um acréscimo na carga de trabalho dos controladores 
envolvidos, desnecessariamente. Na Figura 10, uma mesma rota entra e sai do Setor A duas vezes.

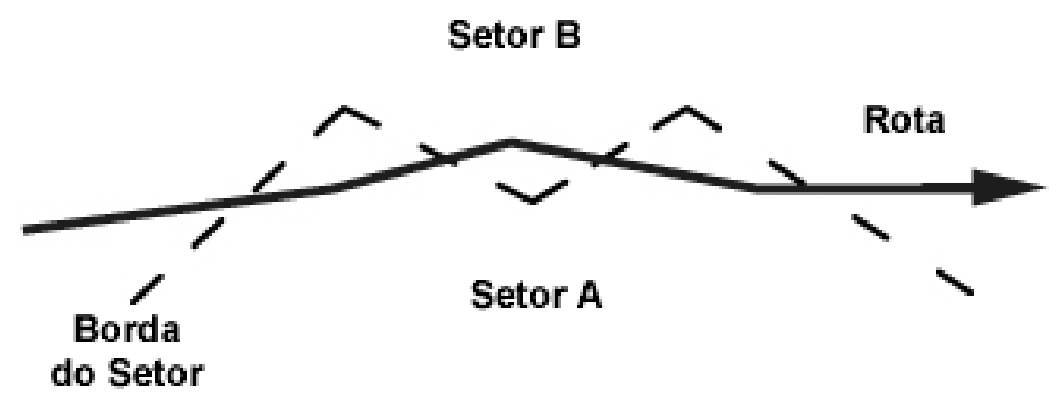

Figura 10 - Exemplo de setores convexos (TRANDAC, DUONG, 2003).

- Distância Mínima entre um Entroncamento e a Borda de um Setor: tem que haver uma distância mínima entre a borda de um setor e o ponto de encontro de duas rotas de aeronaves. Isso tem que ser respeitado para que o controlador de vôo tenha tempo suficiente para resolver um possível conflito nesse entroncamento de rotas, conforme mostra a Figura 11, que apresenta um entrocamento de rotas próximo da fronteira entre os setores A e B.

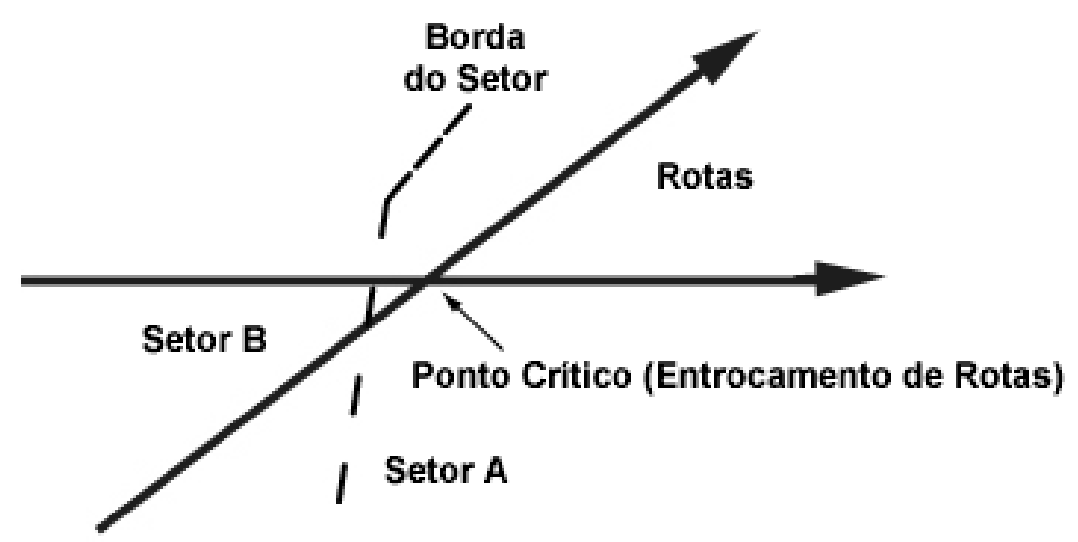

Figura 11 - Distância mínima entre um entroncamento e a borda de um setor (TRANDAC, DUONG, 2003).

- Tempo Mínimo de Permanência no Setor: tem que ser respeitado um tempo mínimo $\left(\mathrm{T}_{\min }\right)$ de permanência de uma aeronave em um determinado setor. Isso é necessário para que o controlador de vôo tenha tempo suficiente para gerenciar o trânsito desta aeronave em seu setor. O tempo mínimo de permanência de uma aeronave em um setor (calculado a partir da distância a ser percorrida pela aeronave e da velocidade da aeronave) pode ser observado na Figura 12. 


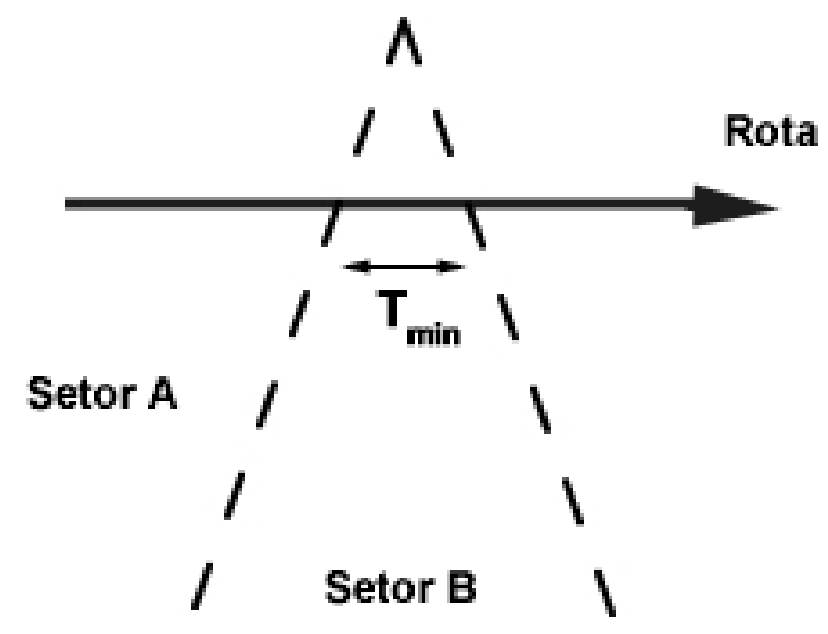

Figura 12 - Tempo mínimo de permanência de uma aeronave em um setor (TRANDAC, DUONG, 2003).

- Conectividade dos Setores: nenhum setor a ser monitorado pode ser desconexo, devendo corresponder a uma região contínua do espaço. Um exemplo de setor desconexo (Setor A) é ilustrado na Figura 13.

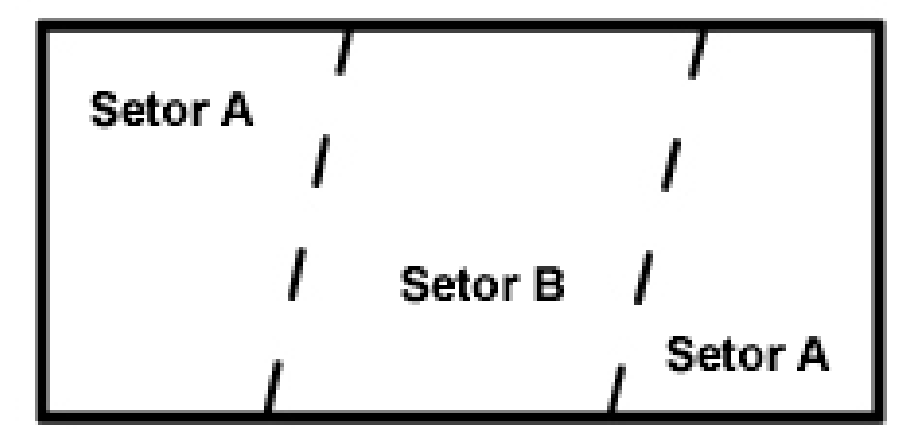

Figura 13 - Exemplo de um setor desconexo (TRANDAC, DUONG, 2003).

Essas restrições apresentadas buscam evitar que as rotas das aeronaves cruzem mais de uma vez um mesmo setor, de forma a não haver uma sobrecarga desnecessária na gerência do tráfego. Estabelecem-se, ainda, um tempo mínimo de permanência da aeronave em cada setor e uma separação mínima entre um entroncamento de rotas e a borda de um setor, diminuindo a probabilidade de conflitos, por garantir um tempo mínimo para que cada controlador gerencie as aeronaves dentro do setor sob sua responsabilidade. 


\subsection{O Controlador de Tráfego Aéreo e a sua Carga de Trabalho}

Com a tecnologia atual, o trabalho desempenhado por um Controlador de Tráfego Aéreo é essencial para garantir a segurança no controle do espaço aéreo. Ele é o único agente na Gerência do Tráfego Aéreo (ATM - Air Traffic Management) capaz de controlar e se comunicar com uma aeronave. Suas principais funções são:

- monitorar as aeronaves contidas no setor sobre sua responsabilidade;

- evitar colisões entre aeronaves;

- gerenciar conflitos entre aeronaves; e

- fornecer informações para os controladores de tráfego aéreo de outros setores.

O controlador de tráfego aéreo tem o poder de alterar a rota de qualquer aeronave, seja por solicitação do piloto, seja por necessidade do controle do tráfego aéreo como um todo.

O sucesso na detecção e resolução de conflitos no espaço aéreo depende da acurácia ${ }^{4}$ dos instrumentos presentes no ATC (Air Traffic Control), nas aeronaves, nos radares, dentre outros. Além disso, depende da resolução e taxa de atualização dos monitores usados pelos controladores de tráfego aéreo e da habilidade dos controladores (auxiliados ou não por ferramentas computacionais) em prever a trajetória futura de uma aeronave (NAVARRETE, 2006). Todos esses mecanismos têm como agente passivo ou ativo o controlador de tráfego aéreo (BOEING, 1997).

Uma das ferramentas principais no controle de tráfego aéreo é o radar. Com esse instrumento, o controlador de tráfego aéreo pode prestar dois tipos de serviços: a vigilância radar e a vetoração radar. A vigilância radar consiste em utilizar as informações transmitidas pelo radar, prestando vigilância sobre as aeronaves, em vôo IFR ou VFR, em um determinado espaço aéreo. Sua principal finalidade é observar desvios significativos sobre a rota desejada ou prevista, além de prestar qualquer tipo de informação relacionada com a segurança do vôo. Quando uma aeronave está sob vigilância radar, a sua navegação é de responsabilidade do piloto que está no comando da aeronave.

Já a vetoração radar consiste em o controlador assumir a navegação da aeronave, emitindo para o piloto comandos de navegação. Este serviço é sempre prestado quando se deseja

\footnotetext{
${ }^{4}$ A acurácia da medida de uma grandeza física está relacionada com o grau de sua conformidade com o valor real (OCHIENG, 2003).
} 
estabelecer separações adequadas entre aeronaves, para orientar as aeronaves na execução de procedimentos especiais, corrigir desvios significativos de rota, evitar colisão entre aeronaves e assegurar a segurança das aeronaves. Ao contrário da vigilância radar, a navegação de uma aeronave sob vetoração radar é de responsabilidade do controlador de vôo que está prestando este serviço (ICA 100-12, 2006).

Toda a comunicação entre os controladores de tráfego aéreo e os pilotos das aeronaves é realizada via fonia, utilizando rádio freqüência (VHF - Very High Frequency). As instruções, solicitações e confirmações são, por definição, feitas utilizando a faixa de frequiência entre 118.000 e $136.975 \mathrm{MHz}$, com intervalo entre as freqüências de $25 \mathrm{kHz}$. Os controladores de tráfego aéreo executam seus procedimentos por meio dessa comunicação de voz, o que é imprescindível no controle de tráfego aéreo atual (IMA 102-9, 1997).

O dia-a-dia de trabalho de um controlador de tráfego aéreo envolve múltiplas tarefas. Além de lidar com as ferramentas do sistema para controlar o tráfego aéreo, ele tem que interagir com os pilotos e coordenar o fluxo de aeronaves com outros controladores durante todo o tempo. Todo este sistema conta com a habilidade do controlador no processamento de informações, no raciocínio rápido e na tomada precisa de decisão. Caso um controlador tome uma decisão equivocada, pode por em risco a vida de dezenas ou centenas de pessoas.

A interação destas tarefas no ATC, aliadas à demanda de tráfego, às condições meteorológicas, ao local de trabalho do controlador e aos requisitos específicos de um setor, compõem a carga de tarefas a qual um controlador é submetido. A reação humana do controlador a essa carga de tarefas é denominada carga de trabalho de um controlador, correspondendo à interação entre as exigências das tarefas e a capacidade humana de realizar essas tarefas (STEIN, 1985).

A carga de trabalho de um controlador de tráfego aéreo pode ser estimada tanto subjetivamente, mediante o uso de questionários e análise de seu comportamento, como objetivamente, utilizando-se de modelos matemáticos. Uma forma de estimar a carga de trabalho de um controlador de tráfego aéreo é utilizando simulações computacionais.

Existem softwares que têm a capacidade de estimar a carga de trabalho de um controlador de tráfego aéreo em decorrência de um tráfego real de aeronaves, como o software RAMS Plus (RAMS, 2005). Nesses softwares podem ser configuradas determinadas tarefas desempenhadas pelos controladores de tráfego aéreo e, para cada tarefa, pode-se associar um valor, ou peso, em função da importância relativa da tarefa no contexto do controle de tráfego 
aéreo. Um peso pode tanto refletir a complexidade da ação de se realizar a tarefa, como o tempo médio estimado para o controlador realizar a tarefa.

Na simulação, as tarefas do controlador de tráfego aéreo são atreladas a eventos que ocorrem durante a execução do vôo. Um exemplo de um evento é a entrada ou saída de uma aeronave de um determinado setor. A este evento pode ser associada a tarefa de receber ou transmitir o controle do tráfego da aeronave que está entrando ou saindo do setor. Durante as simulações computacionais, a cada ocorrência de um evento que está associado a uma tarefa de um controlador de tráfego aéreo é armazenado o tipo da tarefa, qual controlador de tráfego aéreo a executou e o valor ou peso desta tarefa. Somando-se todos os valores das tarefas armazenadas durante a simulação, ponderadas pelos seus respectivos pesos, será possível estimar qual a carga de trabalho assumida por um determinado controlador de tráfego aéreo.

Com o intuito de medir subjetivamente a carga de trabalho de um controlador de tráfego aéreo, a NASA (National Aeronautics and Space Administration) desenvolveu um modelo, denominado NASA-TLX (NASA Task Load Index), para calcular subjetivamente a carga de trabalho associada a uma pessoa quando ela é submetida a tarefas que envolvam interface homem-máquina. O índice fornecido pelo NASA-TLX é obtido por meio da média aritmética entre os resultados de seis sub-escalas, a saber: demanda mental, demanda física, demanda temporal, desempenho, esforço e frustrações. O modelo NASA-TLX pode ser aplicado para calcular a carga de trabalho de qualquer pessoa que trabalhe com sistemas computacionais e, particularmente, permite o cálculo da carga de trabalho de um controlador de tráfego aéreo.

A carga de trabalho de um controlador de tráfego aéreo está diretamente relacionada com o número de aeronaves simultâneas sob sua responsabilidade. O documento da Aeronáutica (MMA 100-30, 1990) estabelece diretrizes para se calcular a carga de trabalho de um controlador de tráfego aéreo, tendo como ponto principal o número de aeronaves controladas simultaneamente por este controlador. Neste documento é definida uma fórmula para o cálculo do número máximo de aeronaves $(N)$ sob controle simultâneo de um controlador de tráfego aéreo, apresentada na Equação 1.

$$
N=\frac{f * d}{n * t_{m} * v_{m}}
$$

Equação 1 - Número máximo de aeronaves controladas simultaneamente por um controlador de tráfego aéreo. 
Nesta equação, $f$ é o fator de disponibilidade do controlador, em porcentagem, representando o percentual de tempo dedicado por ele exclusivamente às comunicações (transmissão/recepção de mensagens) com as aeronaves; não estão inclusas neste tempo quaisquer atividades do controlador que não seja a comunicação com as aeronaves, como a comunicação para coordenação de aeronaves entre setores (por exemplo, a tarefa de transferência de aeronaves entre setores), o tempo destinado a planejamento de tráfego, entre outras. $\mathrm{O}$ fator $d$ representa a distância média percorrida pelas aeronaves no setor, em milhas náuticas. A variável $n$ é o número médio de comunicação de cada aeronave no setor. $\mathrm{O}$ fator $t_{m}$ é o tempo médio de duração de cada mensagem entre o piloto e o controlador. E, por fim, a variável $v_{m}$ representa a velocidade média das aeronaves no setor, em nós.

Analisando a Equação 1, é possível perceber que $\frac{d}{v_{m}}$ é igual ao período $T$, ou seja, $T=\frac{d}{v_{m}}$, que corresponde ao tempo médio que uma aeronave permanece dentro do setor. Assim, temse o modelo simplificado da Equação 1, agora apresentado na Equação 2.

$$
N=\frac{f * T}{n * t_{m}}
$$

Equação 2 - Modelo simplificado do número máximo de aeronaves controladas simultaneamente por um controlador de tráfego aéreo.

A Equação 2 é válida somente nos controles desempenhados no ACC e no APP, não sendo válida para o controle realizado no TWR, pois a dinâmica desse órgão de controle é distinta. É importante salientar que o número máximo de aeronaves controladas simultaneamente por uma posição operacional de um APP é bem menor que o atribuído à posição operacional de um ACC. Isso ocorre devido ao APP ser uma área de convergência de aeronaves, em que as distâncias entre as aeronaves são bem menores quando comparadas as de um ACC; além disso, o número de cruzamento de rotas nesta situação tende a ser bem maior (MMA 100-30, 1990).

Um ponto de destaque apresentado nesta norma é a sugestão do uso de uma re-setorização dinâmica dos setores de controle do espaço aéreo, recomendando, por exemplo, que exista um agrupamento de setores durante o período de baixa demanda de aeronaves, o que tipicamente ocorre durante o período noturno (MMA 100-30, 1990). 


\subsection{Considerações Finais do Capítulo}

Conforme visto neste capítulo, o espaço aéreo é organizado em regiões ou setores nos quais são prestados serviços de informação e controle do tráfego aéreo. Gerenciar todo esse contexto requer uma habilidade conjunta, tanto dos órgãos responsáveis por cada região do espaço aéreo, como também dos pilotos das aeronaves e dos controladores de tráfego aéreo. Esses últimos, os controladores de tráfego aéreo, desempenham papel importante no contexto do tráfego aéreo mundial.

Para promover segurança no controle do tráfego de aeronaves no espaço aéreo, o controlador de tráfego aéreo realiza inúmeras tarefas que o expõe a uma determinada carga de trabalho. No Capítulo 3 é abordado e ilustrado o conceito de re-setorização dinâmica, uma técnica que pode ajudar a balancear a carga de trabalho dos controladores de tráfego aéreo em um órgão de controle específico, como um ACC ou um APP. 


\section{Re-setorização Dinâmica}

Este capítulo tem como objetivo apresentar a Re-setorização Dinâmica (RD). Inicialmente é apresentada uma introdução a respeito do conceito da RD, contextualizando sua aplicação. Após esta apresentação, a RD é abordada de forma teórica, mostrando qual o seu objetivo, como ela pode ser estruturada e aplicada. Finalmente, este capítulo apresenta um estudo da relação desta técnica com os fatores humanos envolvidos, mostrando qual a relação da RD com a carga de trabalho dos controladores de tráfego aéreo.

\subsection{Introdução}

O Controle de Tráfego Aéreo (ATC - Air Traffic Control) é uma função essencial do transporte aéreo que visa garantir a segurança das aeronaves em solo e em vôo. Conforme descrito no Capítulo 2, o espaço aéreo é dividido virtualmente em setores nos quais um ou mais controladores de tráfego aéreo são responsáveis por monitorar os aviões, evitar colisões entre as aeronaves, gerenciar conflitos e fornecer informações para os controladores de tráfego aéreo de outros setores.

Inicialmente essas fronteiras virtuais foram criadas baseadas em um cenário bem diferente do existente hoje em dia. Nos primórdios da aviação, no início e meados do século XX, o tráfego aéreo era bem menor do que o atual. Em outras palavras, os controladores eram responsáveis por controlar muito menos aeronaves simultaneamente.

Com o crescimento cada vez maior da demanda por transporte aéreo, tende a aumentar a densidade de aeronaves nos setores, medida em número de aeronaves por setor. Cada vez mais os controladores de tráfego aéreo têm que dedicar mais atenção no seu trabalho e manter concentração devido ao número maior de aeronaves a serem gerenciadas em um determinado espaço de tempo, gerando um aumento da carga de trabalho (workload) e, caso esse processo não seja bem controlado, pode gerar estresse no controlador de tráfego aéreo, prejudicando a qualidade de seu trabalho. 
Em determinados órgãos de ATCs (ACC ou APP), nos períodos de alta densidade de aeronaves por setor, tem-se empregado o uso de mais de um controlador por setor, buscando promover melhores condições para os controladores realizarem suas tarefas e equilibrar a carga de trabalho de cada pessoa envolvida. Um primeiro controlador, denominado controlador tático, passa a ser responsável por acompanhar as aeronaves dentro do setor, emitindo ordens e autorizações para o piloto e controlando as situações mais imediatas. $\mathrm{O}$ segundo controlador, denominado controlador estratégico, fica responsável por gerenciar as aeronaves durante a troca de setores, ou seja, entre o seu setor e os setores adjacentes (VINK, 1997).

Segundo (WYNDEMERE, 1997; WILHELMSEN et al., 1999a), a Re-setorização Dinâmica (RD), do inglês Dynamic Resectorization (DR), é a habilidade para se fazer ajustes táticos nas fronteiras dos setores do espaço aéreo, buscando-se uma maior flexibilidade para gerenciar situações que possam aumentar a carga de trabalho dos controladores de tráfego aéreo e, conseqüentemente, introduzir atrasos (delays) indesejáveis no sistema de controle de tráfego.

A RD é um dos processos concebidos para lidar com a crescente demanda por transporte aéreo, que tem como resultado uma também crescente densidade de aeronaves nos espaços aéreos definidos. Trata-se de um conceito que visa facilitar a gerência dos espaços aéreos, e não uma solução para problemas de congestionamento do espaço aéreo, embora possa eventualmente contribuir para mitigar tal situação. Com a RD não é possível prever todas as condições de saturação do espaço aéreo, sendo seu principal objetivo maximizar a capacidade dos setores, buscando equilibrar a carga de trabalho dos controladores de tráfego aéreo.

\subsection{Definições}

A RD é a capacidade de se ajustar taticamente as bordas virtuais dos setores de controle de tráfego aéreo em respostas às mudanças no fluxo de aeronaves no espaço aéreo, ou ainda devido a outros fatores (por exemplo, mudanças climáticas). Com o aumento do fluxo de aeronaves no espaço, o gerenciamento do controle de tráfego aéreo precisa evoluir continuamente para atender a uma maior demanda, sem que isso possa causar um aumento de risco para a segurança do transporte aéreo. Alguns estudos estão sendo realizados para se reconfigurar os setores de controle por intermédio de divisão ou combinação (junção) de setores e/ou deslocamento de suas fronteiras (TABER, WOODWARD, SMALL, 2000). Essas re- 
configurações e ajustes visam equilibrar a carga de trabalho do controlador de tráfego aéreo associada a cada setor, prevenir restrições de tráfego e minimizar atrasos decorrentes de uma eventual sobrecarga ao sistema de transporte aéreo.

Um dos métodos que busca resolver esses problemas é a RD por meio da re-configuração dos setores pelo movimento vertical e/ou horizontal de suas bordas, bem como por meio da divisão ou junção dos setores. A RD, porém, não tem como finalidade re-configurar as rotas das aeronaves (HADLEY, SOLLENBERGER, 2001).

Para gerar tais re-configurações são levados em conta o fluxo de aeronaves no espaço aéreo, as possíveis tendências de mudanças no tráfego em instantes futuros, o clima e diversos outros fatores do ATC, como por exemplo o conhecimento adquirido ao longo dos anos pelos controladores de tráfego aéreo. Seu principal objetivo é promover diversas modificações de configurações de setores que atendam a diversos tipos de requisitos, buscando balancear a carga de trabalho do controlador de tráfego aéreo.

Em um espaço aéreo bem estruturado (espaço aéreo com tráfego complexo e constante ao longo do tempo) em que exista uma alta densidade de aeronaves nos setores, a RD pode ser aplicada por meio do chaveamento de cenários, cada qual com uma configuração de setores pré-definidos. Estes setores podem ser criados e dimensionados a partir de modelos baseados no histórico do tráfego aéreo da região, por decisões estratégicas ou pela experiência obtida junto aos especialistas no assunto (os próprios controladores de tráfego aéreo). Neste caso, existe um conjunto limitado de configurações de setores que atenda a vários destes requisitos. Esse processo é chamado de Limited DR (LDR) ou RD Limitada (RDL). A RDL permite o gerenciamento do tráfego aéreo baseado no chaveamento entre configurações de controle de um determinado espaço aéreo, dentre um número limitado de grupos de configurações de setores pré-definidas (WILHELMSEN et al., 1999a; TABER, WOODWARD, SMALL, 2000).

Contudo, em um espaço menos estruturado (espaço em que o tráfego tenda a ser menos constante ao longo do tempo), a criação de modelos baseados no histórico desse tráfego chega a ser quase que inócua. A RD, neste caso, precisa ser mais flexível. Esse processo de RD mais flexível é chamando de Unrestrited DR (UDR) ou RD Irrestrita (RDI). A RDI precisa atender às necessidades de gerência do tráfego aéreo sem restrições e, por isso, acaba sendo muito mais ampla que a RDL. Na RDI é criado um conjunto de padrões (templates) de setores prédefinidos. Diferentemente da RDL, esses padrões podem ser ajustados de forma on-line para atender a situações particulares. Entretanto, segundo (WILHELMSEN et al., 1999a) a RDI 
requer um novo sistema de automação com alta capacidade de processamento que não deve ser alcançado em um futuro próximo.

Apesar de a RD poder ser realizada on-line, ela não é contínua nem realizada em tempo real. Uma movimentação contínua e em tempo real das bordas dos setores resultaria em um cenário que estaria em constante mudança, o que aumentaria o número de variáveis dinâmicas de configuração dos setores, resultando em provável crescimento da carga de trabalho do controlador de tráfego aéreo. Tudo isso sem considerar o estresse gerado por essa mudança constante de fronteiras dos setores. O poder computacional para analisar, prever e reconfigurar em tempo real as bordas dos setores seria alto para os padrões computacionais atuais e, conseqüentemente, muito caro, além de trazer benefícios questionáveis, de acordo com (WILHELMSEN et al., 1999a, 1999b, 1999c; TABER, WOODWARD, SMALL, 2000).

\subsection{Um Exemplo de Re-setorização Dinâmica Irrestrita (RDI)}

Tanto na RDL, como na RDI, supõem-se a criação de um conjunto de configurações ("templates") de setores pré-definidos que devam ser chaveados no tempo a fim de se balancear a carga de trabalho dos controladores de tráfego aéreo. Todas essas configurações são criadas a partir do estudo do histórico de ocupação de um espaço aéreo, levando-se em conta mudanças climáticas previsíveis e a própria experiência dos controladores de tráfego aéreo.

A RDI difere da RDL pela sua abrangência. Na RDL, uma vez determinada a configuração dos setores, esta configuração não sofre mais mudanças, nem na hora do chaveamento, nem durante a operação de controle do tráfego aéreo. Contudo, na RDI podem ocorrer mudanças on-line na configuração pré-estabelecida de um setor, quer seja durante a operação de controle de tráfego aéreo, quer seja no momento do chaveamento entre configurações de setores.

Uma forma mais simples de apresentar a RDI ocorre em situações quando um mau tempo inesperado e imprevisível se instala em um determinado setor do espaço aéreo, provocando a necessidade de re-arranjo das rotas das aeronaves. Este re-arranjo poderia causar, em situações particulares de geometria dos setores e posicionamento do mau tempo, em um estreitamento das distâncias entre as rotas das aeronaves bem na fronteira entre dois setores adjacentes. Esse cenário é apresentado na Figura 14. Com isso, os controladores de tráfego 
aéreo, além de lidar com o mau tempo, teriam que administrar o afunilamento das rotas das aeronaves na zona de transição entre os setores.

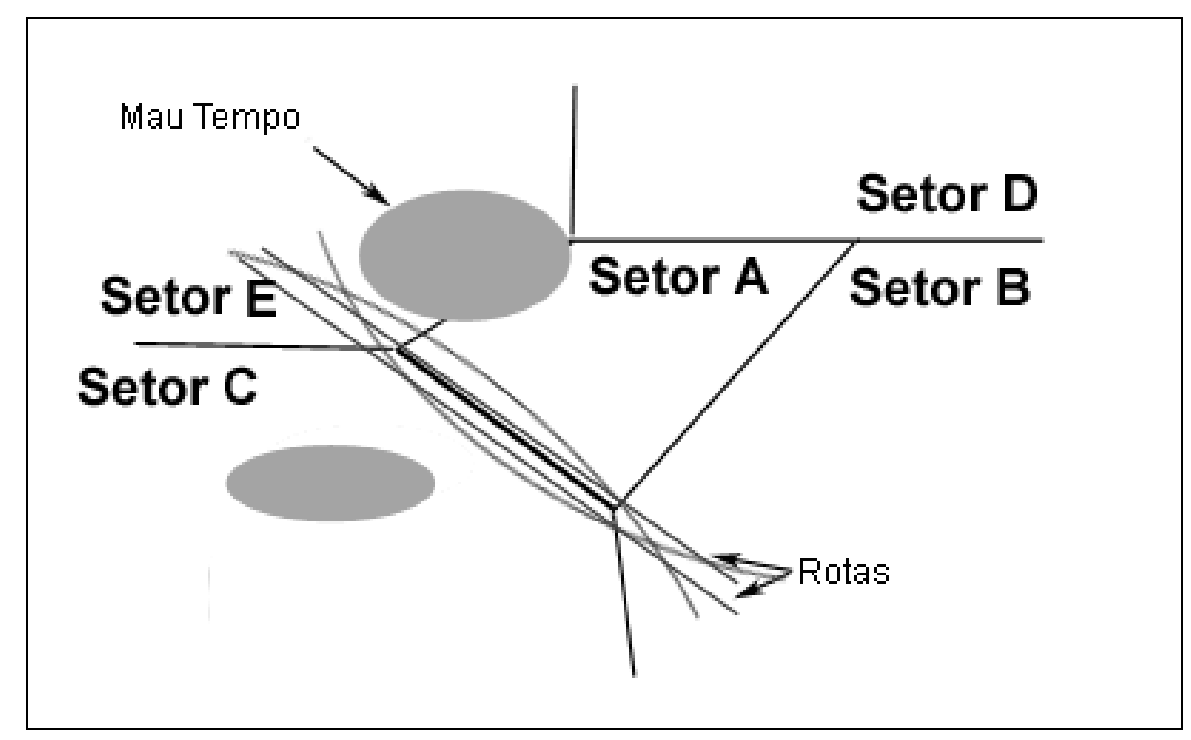

Figura 14 - Exemplo de necessidade de re-configuração de rotas de aeronaves devido ao mau tempo.

Este caso apresentado na Figura 14 corresponde a uma possível situação real em que houve um afunilamento das rotas das aeronaves para a borda comum aos setores $\mathrm{C}$ e $\mathrm{A}$, devido a duas áreas de instabilidades climáticas. Supõe-se que para essa configuração mostrada não exista um arranjo pré-definido de setores que possa ser chaveado para melhor acomodar esta situação. Sendo assim, um conjunto de setores pré-configurados e estáticos da RDL não consegue atender de forma satisfatória a este cenário.

É exatamente neste ponto que a RDI mostra-se adequada, com a capacidade de ajuste on-line da configuração de um determinado conjunto de setores. A Figura 15 mostra como a RDI pode ser aplicada na situação descrita e ilustrada na Figura 14.

Para resolver o problema de afunilamento das rotas entre dois setores adjacentes devido ao mau tempo, pode ser aplicada a RDI, ou seja, o estabelecimento de uma re-configuração online na linha divisória dos setores $\mathrm{A}$ e $\mathrm{C}$ de forma que a zona de instabilidade não ocorra exatamente na área de transição destes setores. Com isso o controlador do setor A precisa se preocupar somente em administrar e controlar a instabilidade causada pelo mau tempo sem ter que se comunicar constantemente com o controlador do setor $\mathrm{C}$ a fim de coordenar as conseqüências dessa instabilidade (vide Figura 15). 


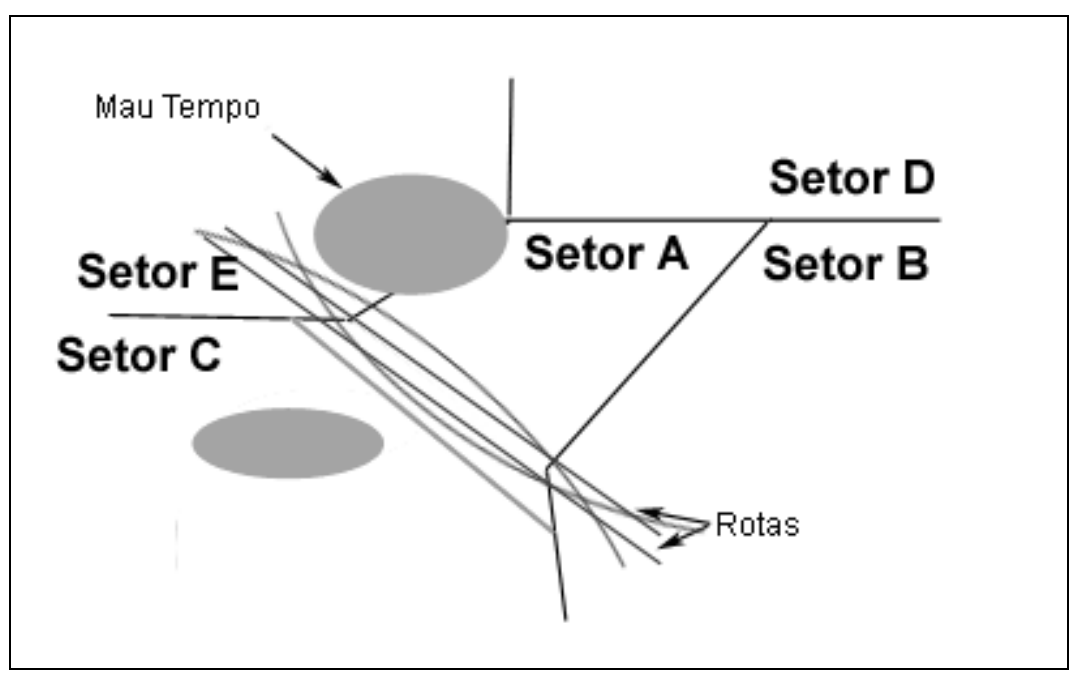

Figura 15 - Aplicação da RDI com re-configuração de setores devido ao mau tempo.

Atualmente os ATCs não têm ferramentas capazes de realizar a RDI. Contudo, estudos estão sendo realizados buscando analisar mais profundamente as vantagens e desvantagens da RDI e as formas de viabilizá-la (WILHELMSEN et al., 1999a, 1999d, 1999e). Naturalmente, como a RDL é mais limitada que a RDI, é razoável supor-se que, inicialmente, a RDL venha a ser aplicada em um ATC, sendo a RDI uma evolução natural e mais abrangente dessa técnica.

\subsection{Exemplos Típicos de Aplicação da Re-setorização Dinâmica Limitada (RDL)}

A RD pode ser aplicada em diferentes situações estratégicas. Este tópico busca ampliar o horizonte do uso da RD, descrevendo e exemplificado seis casos nos quais a RDL pode ser aplicada. O objetivo final em todos os casos citados é equilibrar a carga de trabalho dos controladores de tráfego aéreo nos setores envolvidos e, conseqüentemente, evitar atrasos no sistema de gerenciamento do tráfego aéreo.

Os seis casos a serem explorados foram agrupados em quatro itens, que são apresentados a seguir (TABER, WOODWARD, SMALL, 2000; WILHELMSEN et al., 1999b):

1. Indisponibilidade de Equipamentos;

2. Mudanças Climáticas;

3. Uso Especial do Espaço Aéreo; e

4. Volume de Tráfego. 


\subsubsection{Indisponibilidade de Equipamentos}

A indisponibilidade de equipamentos, seja por falha ou manutenção preventiva, utilizados na vigilância do tráfego aéreo pode afetar o nível de serviço no ATC. Problemas de indisponibilidade em um radar responsável por auxiliar o controle de tráfego aéreo em um determinado setor pode resultar na aplicação das regras de separação de aeronaves por vigilância sem radar. Essas regras aumentam a carga de trabalho do controlador de tráfego aéreo e diminui o número de aeronaves que o setor pode acomodar.

Uma forma de minimizar o impacto devido à indisponibilidade do radar é delegar, temporariamente, para outro setor adjacente, a área do espaço que ficou sem cobertura temporária, caso este setor possa prover cobertura de radar para essa área. Essa cooperação entre setores pode evitar o uso das regras de separação mais restritiva entre aeronaves pelo método de vigilância sem radar, evitando a conseqüente diminuição da capacidade do espaço aéreo e o aumento da carga de trabalho dos controladores de tráfego aéreo, minimizando também os atrasos dos vôos.

A Figura 16 ilustra dois setores com as respectivas linhas de cobertura dos radares. O setor A utiliza os radares $\mathrm{X}$ e $\mathrm{Y}$ para controlar as aeronaves, enquanto o setor B utiliza o radar Z. Quando existe uma indisponibilidade do radar Y, os controladores do setor A têm que aplicar as regras de separação de aeronaves sem cobertura de radar para a região que só é coberta pelo radar Y.

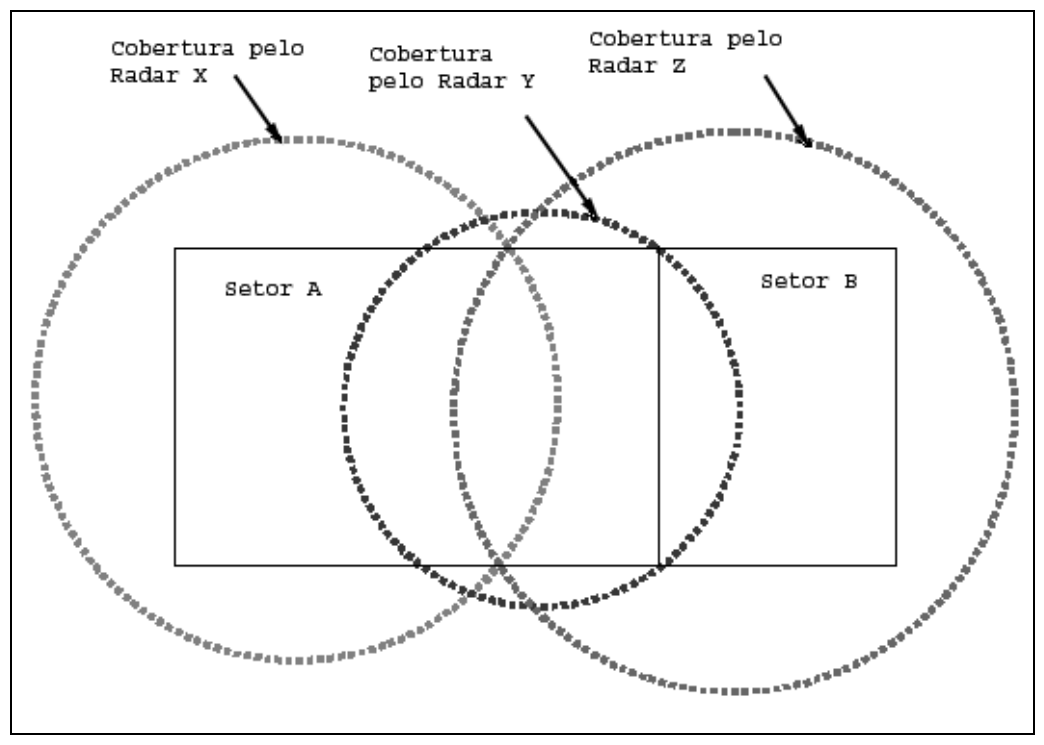

Figura 16 - Controle do espaço aéreo antes da indisponibilidade de um radar (TABER, WOODWARD, SMALL, 2000). 
Isso pode ser administrado caso exista uma política entre esses dois setores adjacentes para, quando o radar $\mathrm{Y}$ falhar, o setor B assumir a região do setor A que ficou sem cobertura. Assim, o setor B pode prover serviço de separação por radar porque a região do setor A coberta pelo radar Y também pode ser coberta pelo radar Z. Com esse acordo estabelecido, não será necessário aplicar as regras de separação de aeronaves sem cobertura de radar. A Figura 17 ilustra a situação na qual uma parte do setor A é delegada para o setor B controlar.

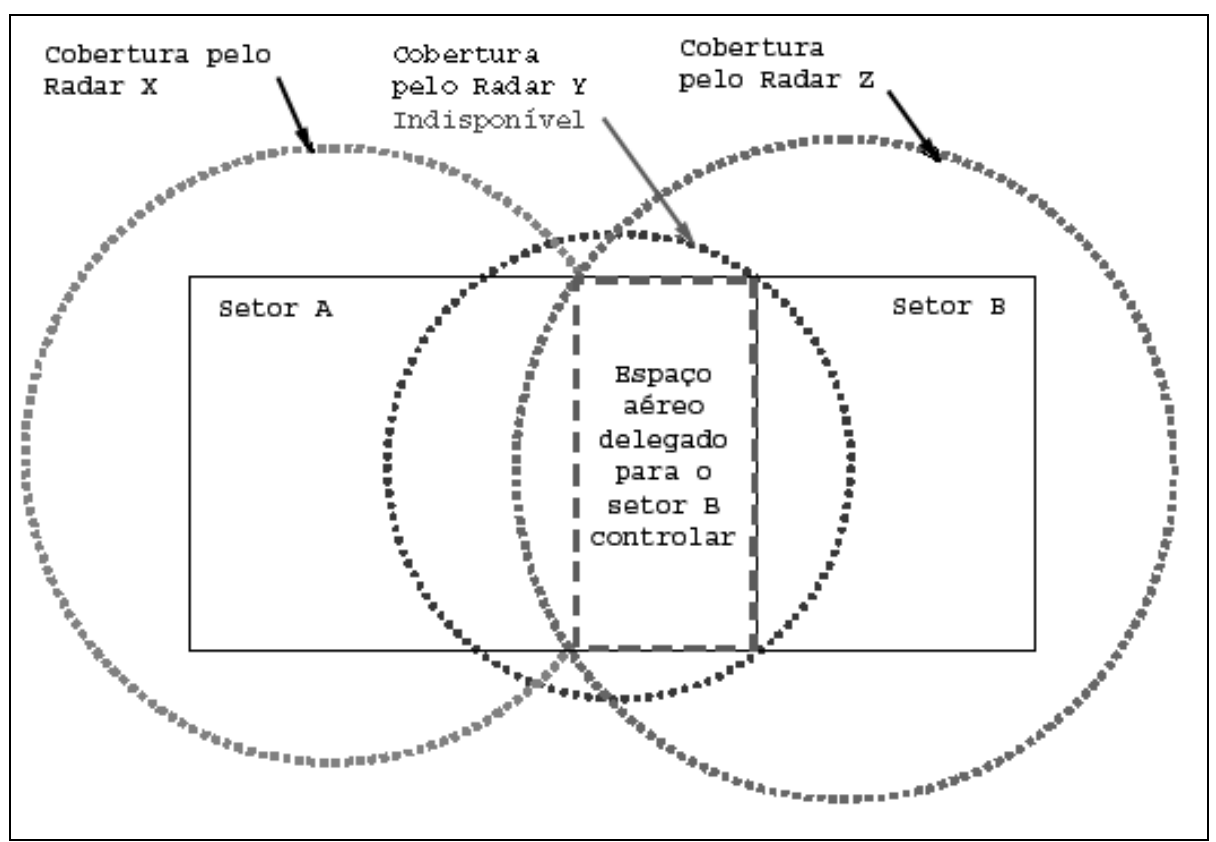

Figura 17 - Controle do espaço aéreo depois da indisponibilidade de um radar (TABER, WOODWARD, SMALL, 2000).

Hoje essa técnica de delegar parte do setor que ficou sem cobertura de radar devido a uma indisponibilidade, a um setor adjacente, é usada na Flórida (Estados Unidos). A Figura 18 mostra dois centros de controle, o ATC de Miami e o ATC de Jacksonville. O centro de Miami é responsável por controlar o fluxo de aeronaves em direção ao sul da Flórida. Nesta figura é possível observar as áreas cobertas por seus respectivos radares. 


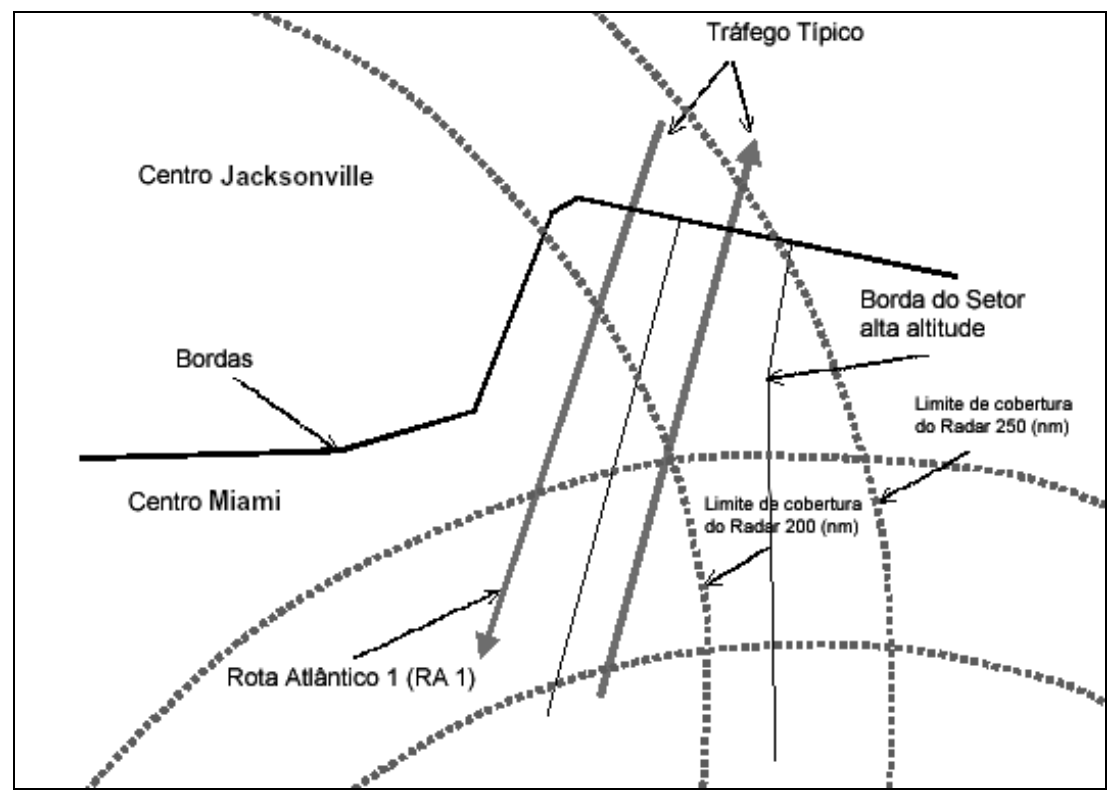

Figura 18 - Cobertura de radar sobre o centro de Miami (TABER, WOODWARD, SMALL, 2000).

A Figura 19 mostra um novo mapa do espaço aéreo controlado por esses dois centros quando existe uma indisponibilidade dos radares de cobertura do centro de Miami. Nesse mapa é possível ver uma área denominada de HOBEE. A área HOBEE é coberta tanto pelos radares do Centro de Miami como pelos de Jacksonville. Portanto, caso existam indisponibilidades nos radares do Centro de Miami, o Centro e Jacksonville pode assumir o controle da área HOOBE.

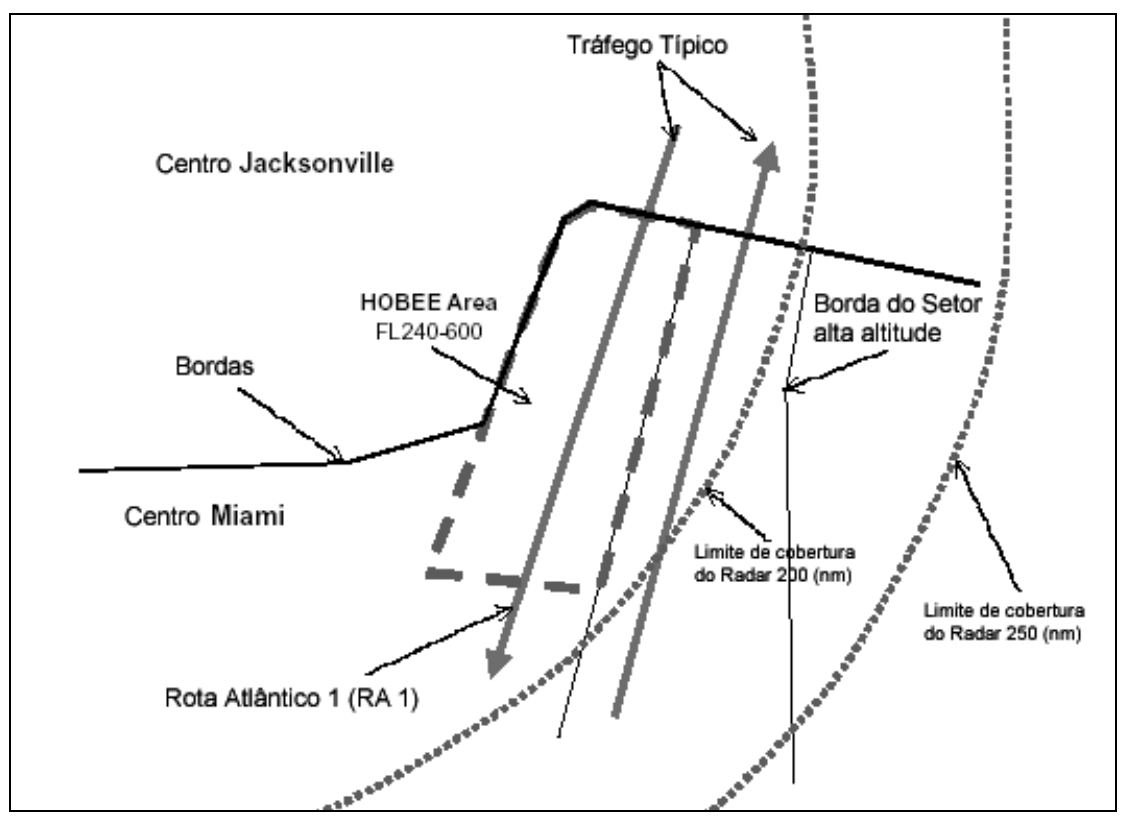

Figura 19 - Centro de Jacksonville com cobertura de radar para a área HOBEE (TABER, WOODWARD, SMALL, 2000). 
Neste caso, existem procedimentos e regras para o chaveamento dessas configurações. Os mapas são previamente definidos para acomodar estrategicamente a falha nesses radares e conhecidos antecipadamente pelos dois centros. Quando o Centro de Miami delega a área HOBEE para o Centro de Jacksonville, o Centro de Jacksonville chaveia para o mapa com a configuração onde a área HOBEE fica sobre sua responsabilidade. Em contrapartida, o Centro Miami muda sua configuração do espaço para o mapa em que a área HOBEE fica pintada, destacando que o controle dessa área está sobre a responsabilidade do Centro de Jacksonville.

Uma outra vantagem desta abordagem é que esse procedimento com a área HOBEE também pode ser usado durante a manutenção preventiva dos radares, sem comprometer o controle de tráfego aéreo dessa região.

\subsubsection{Mudanças Climáticas}

O tempo afeta diretamente o tráfego aéreo e, muitas vezes, as aeronaves precisam alterar suas rotas para não se depararem com um mau tempo, ou adaptá-las para melhor aproveitar o sentido do vento. Isso ocorre, por exemplo, em situações em que as aeronaves requisitam mudança de altitude para desviar de uma turbulência ou tempestade. Todas essas mudanças afetam o fluxo de tráfego aéreo nos setores envolvidos, e uma mudança adaptativa nas bordas destes setores poderia acarretar uma melhor acomodação do fluxo de aeronaves, proporcionando um equilíbrio na carga de trabalho dos controladores de tráfego aéreo. Neste tópico é abordado como a RDL pode ajudar a equilibrar a carga de trabalho dos controladores de tráfego aéreo em condições climáticas adversas.

\subsubsection{Mau tempo}

Um mau tempo, sem muitas instabilidades, em geral pode ser atravessado pelas aeronaves sem por em risco a segurança do vôo. Contudo, para outras situações de mau tempo intenso, em que a travessia aumentaria o risco de um acidente, a rota de uma aeronave é modificada, evitando-se cruzar tais regiões. Essa modificação pode fazer com que o fluxo de aeronaves em um determinado setor aumente, o que significa que a reestruturação na rota é feita de tal modo 
ela passe a pertencer a um determinado setor que não a continha antes da mudança. Esse aumento emergencial na densidade de aeronaves dentro de um setor pode ocasionar um aumento da carga de trabalho do controlador de tráfego aéreo do setor afetado.

Usar uma estratégica de adaptação no gerenciamento dos setores afetados pelo tempo pode resolver esse problema, utilizando a cooperação entre setores adjacentes. A Figura 20 mostra um exemplo genérico de partida e chegada de aeronaves em um determinado aeroporto.

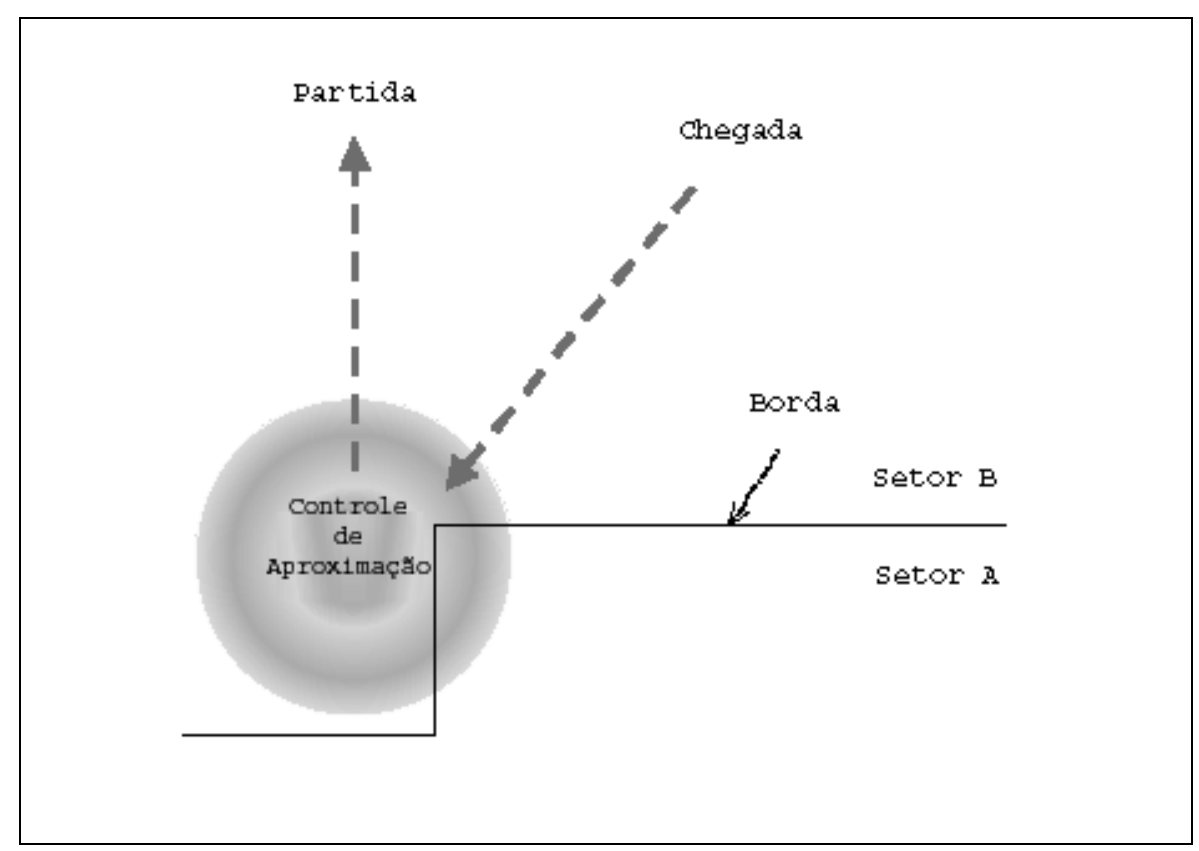

Figura 20 - Configuração genérica de dois setores com tempo bom (TABER, WOODWARD, SMALL, 2000).

Quando uma tempestade (mau tempo) se dirige para a zona de aproximação, mostrada na Figura 21, as rotas de chegada e partida são então re-configuradas para desviar desse mau tempo. A rota de chegada é então direcionada para dentro do Setor A, provocando um aumento de aeronaves nesse setor, o que pode gerar um crescimento da carga de trabalho dos controladores do setor A. Contudo, uma negociação entre os setores A e B pode criar uma zona justamente onde foi redirecionado a rota de chegada devido ao mau tempo. Essa zona passaria a ser controlada pelo setor $\mathrm{B}$, acomodando as mudanças devido ao mau tempo e mantendo o fluxo de aeronaves do setor B, sem influenciar no fluxo de aeronaves do setor A, conforme ilustrado na Figura 21. 


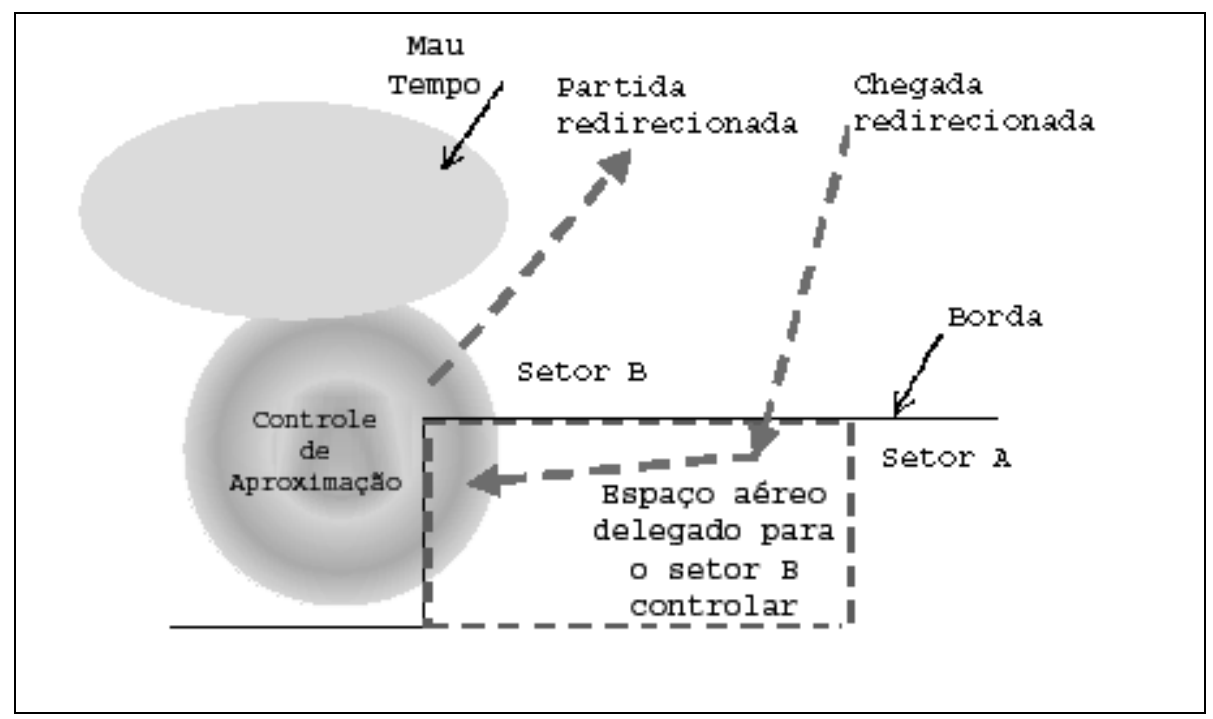

Figura 21 - Configuração genérica de dois setores com mau tempo (TABER, WOODWARD, SMALL, 2000).

Um outro exemplo é ilustrado na Figura 22. A Figura 22(a) representa um espaço aéreo hipotético com dois setores e as rotas das aeronaves sobre este espaço. Supondo que um mau tempo se instale sobre este espaço, as rotas das aeronaves podem ser desviadas segundo o apresentado na Figura 22(b). Neste caso, a zona de mau tempo situou bem na borda entre dois setores, ocasionado um afunilamento das rotas nesta borda.

Os controladores de tráfego aéreo responsáveis pelo setor 1 e 2 terão que ter maior atenção na transmissão das aeronaves de um setor para o outro devido ao cruzamento de rotas e a uma diminuição das distâncias entre elas exatamente na borda que separa os dois setores. Em outras palavras, o mau tempo trouxe um aumento na carga de trabalho dos controladores.

Uma forma de diminuir a carga de trabalho desses controladores é reestruturar as bordas dos setores segundo a Figura 22(c). Neste caso, houve uma diminuição do tamanho do setor 1 de tal forma que o afunilamento e o cruzamento de rotas deixam de ocorrer exatamente em cima da borda que divide os dois setores. Com isso, um único controlador de tráfego aéreo pode controlar as aeronaves nessa parte delicada do espaço aéreo, sem haver a necessidade de se preocupar com a tarefa de transmissão de aeronaves de um setor para o outro. 


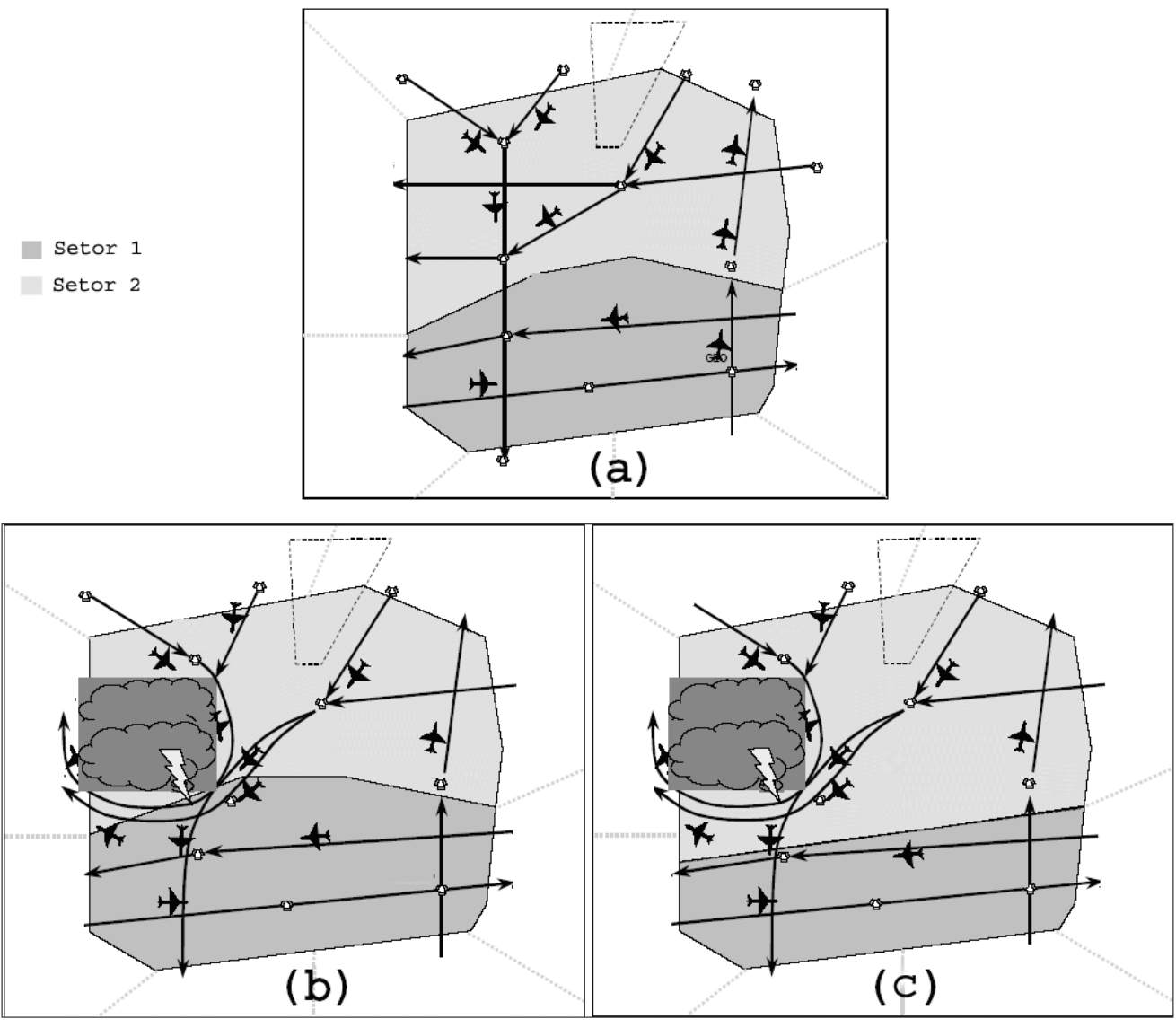

Figura 22 - Exemplo de re-setorização devido ao mau tempo (HADLEY et al., 2000).

A Figura 23 apresenta o espaço aéreo de Orlando em situação de tempo bom. Quando um mau tempo passa pelo norte de Orlando, as rotas de partida e de chegada são re-configuradas em direção ao leste.

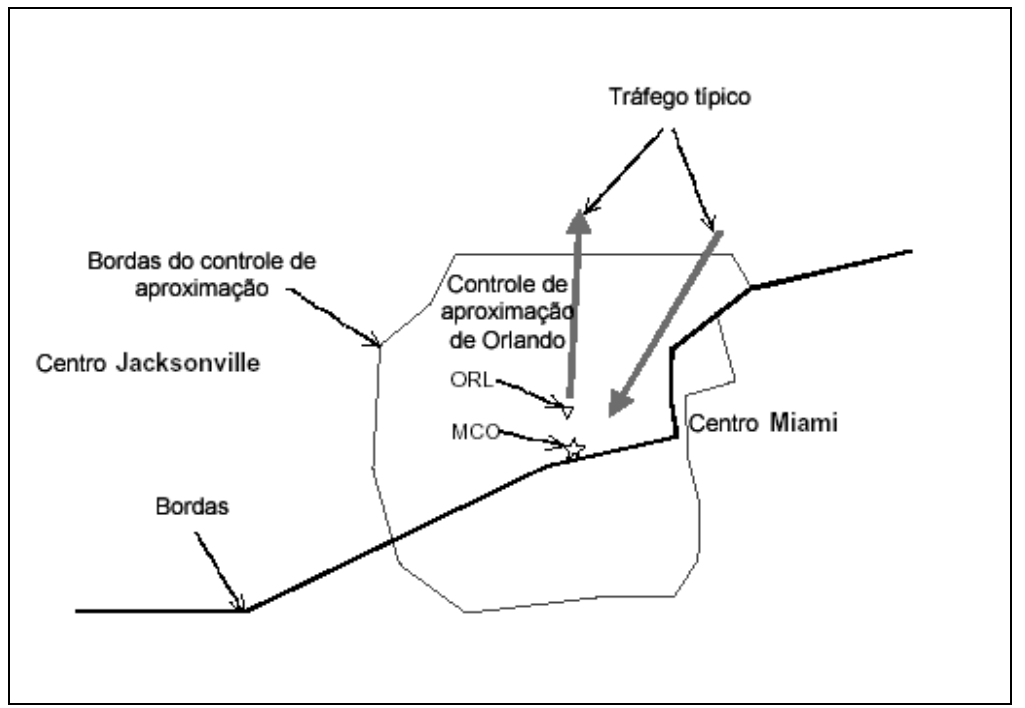

Figura 23 - Espaço aéreo de Orlando com tempo bom (TABER, WOODWARD, SMALL, 2000). 
Para acomodar essa re-configuração, o Centro de Miami e o Centro de Jacksonville criaram uma área chamada MALET, mostrada na Figura 24. Quando o mau tempo se aproxima do norte de Orlando, o Centro de Miami e o Centro de Jacksonvinlle negociam o chaveamento da área MALET representada no mapa. O Centro de Miami delega o controle da área MALET para o Centro de Jacksonvile, que ficará responsável por controlar as aeronaves na área MALET. O Centro de Miami, neste caso, ainda é responsável por controlar as aeronaves no seu setor, mas fora da área MALET.

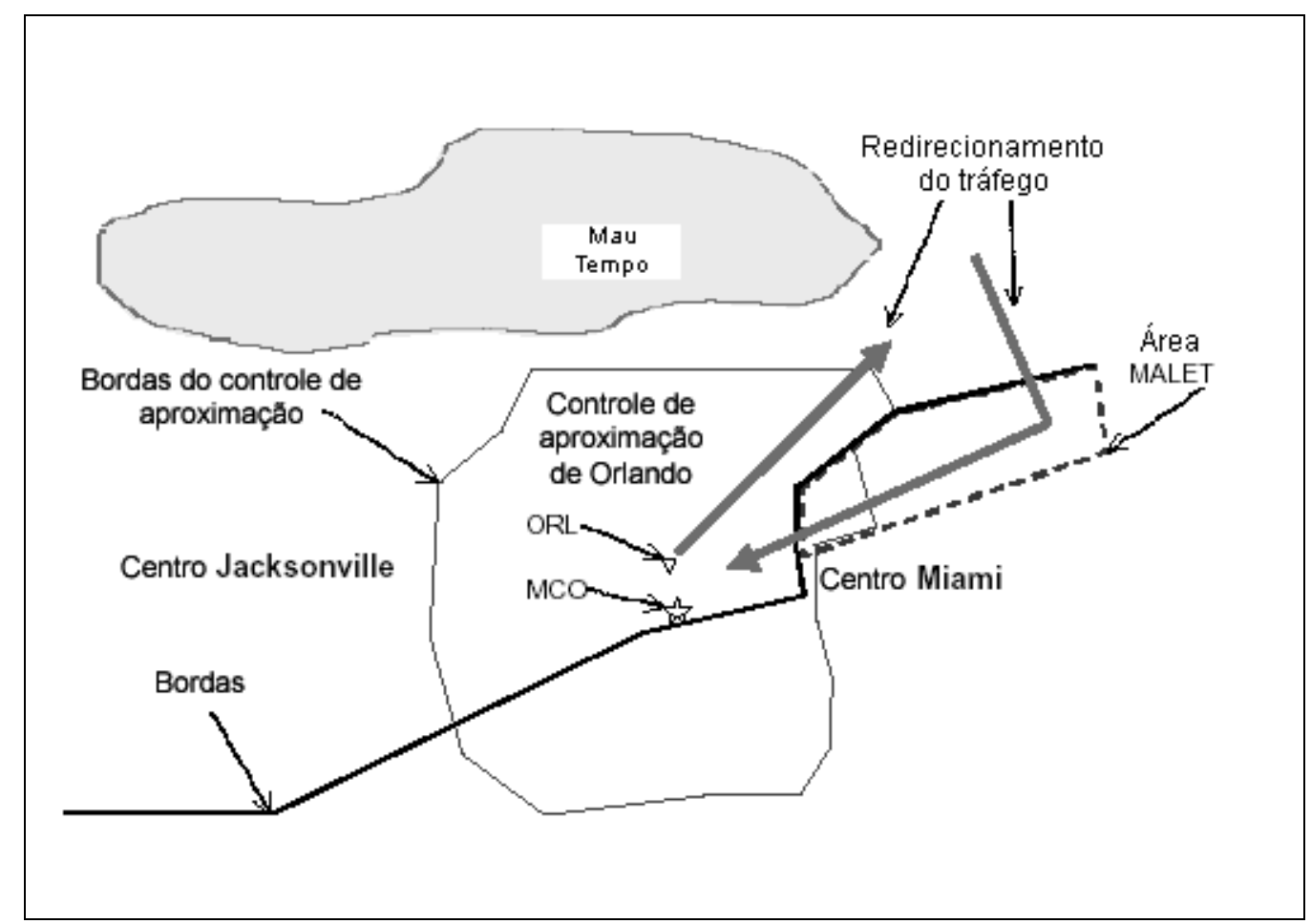

Figura 24 - Espaço aéreo de Orlando, com a área MALET, usada em casos de mau tempo (TABER, WOODWARD, SMALL, 2000).

Um detalhe importante é que os vôos que chegam pelo leste para Orlando são redirecionados mais para o sul para dentro do Centro de Miami, pelo Controle de Aproximação de Orlando, atingindo a área MALET. Apesar desses vôos passarem fisicamente pelo espaço aéreo que era controlado pelo centro de Miami, com a ativação da área MALET esses vôos serão controlados pelo centro de Jacksonville. Com isso, a criação da área MALET e a passagem do seu controle para Jacksonville conseguem manter constante o mesmo fluxo de aeronaves em ambos os setores, antes e depois da re-configuração. 


\subsubsection{Mudança na Configuração dos Aeroportos}

Em alguns aeroportos, as suas configurações mudam devido a variações freqüentes na direção do vento. Redefinir os setores das áreas terminais devido a essas mudanças pode melhor acomodar o tráfego e diminuir a carga de trabalho dos controladores de tráfego aéreo.

A Figura 25 e a Figura 26 mostram a configuração de uma área terminal genérica usada em duas possíveis configurações do aeroporto. Uma configuração, chamada de configuração Leste (Figura 25), ocorre quando um avião tem que decolar no sentido leste, mas sua rota de partida apresenta decolagem no sentido oeste. A outra configuração, chamada de configuração Oeste (Figura 26), ocorre quando o avião tem que decolar no sentido oeste, mas sua rota de partida fica a leste. Essas duas configurações podem ser chaveadas estrategicamente de acordo com a operação do aeroporto.

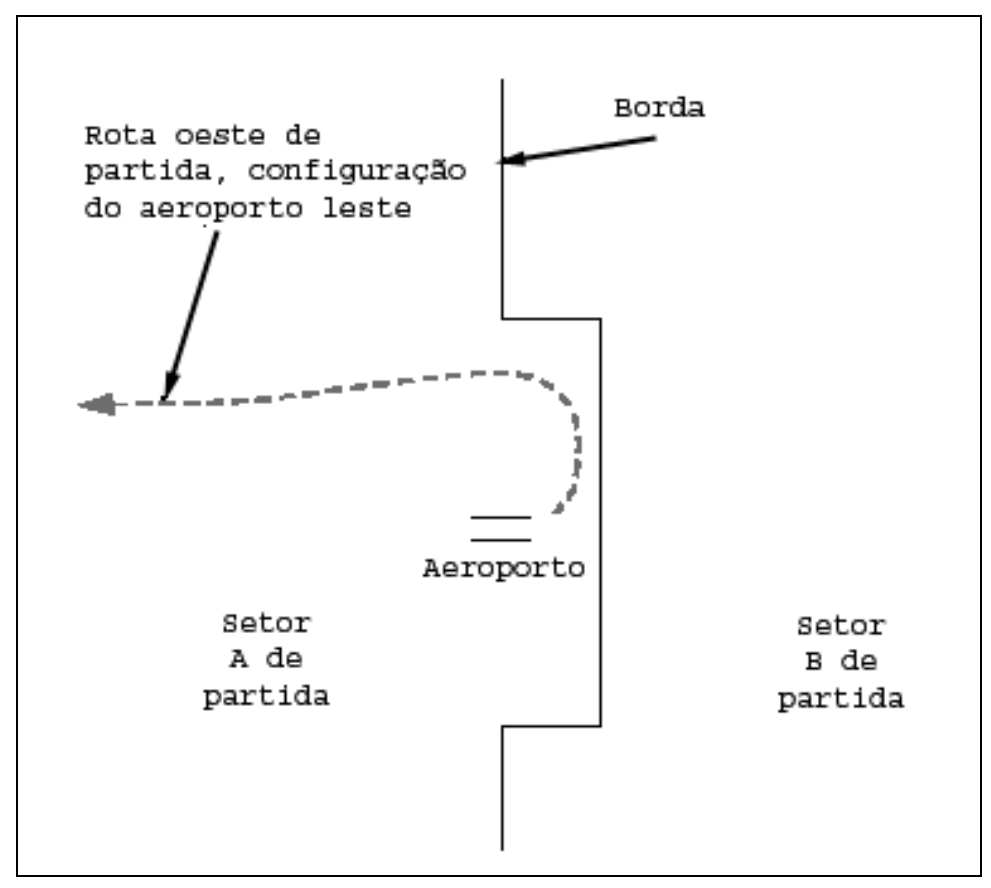

Figura 25 - Configuração genérica para operação Leste (TABER, WOODWARD, SMALL, 2000). 


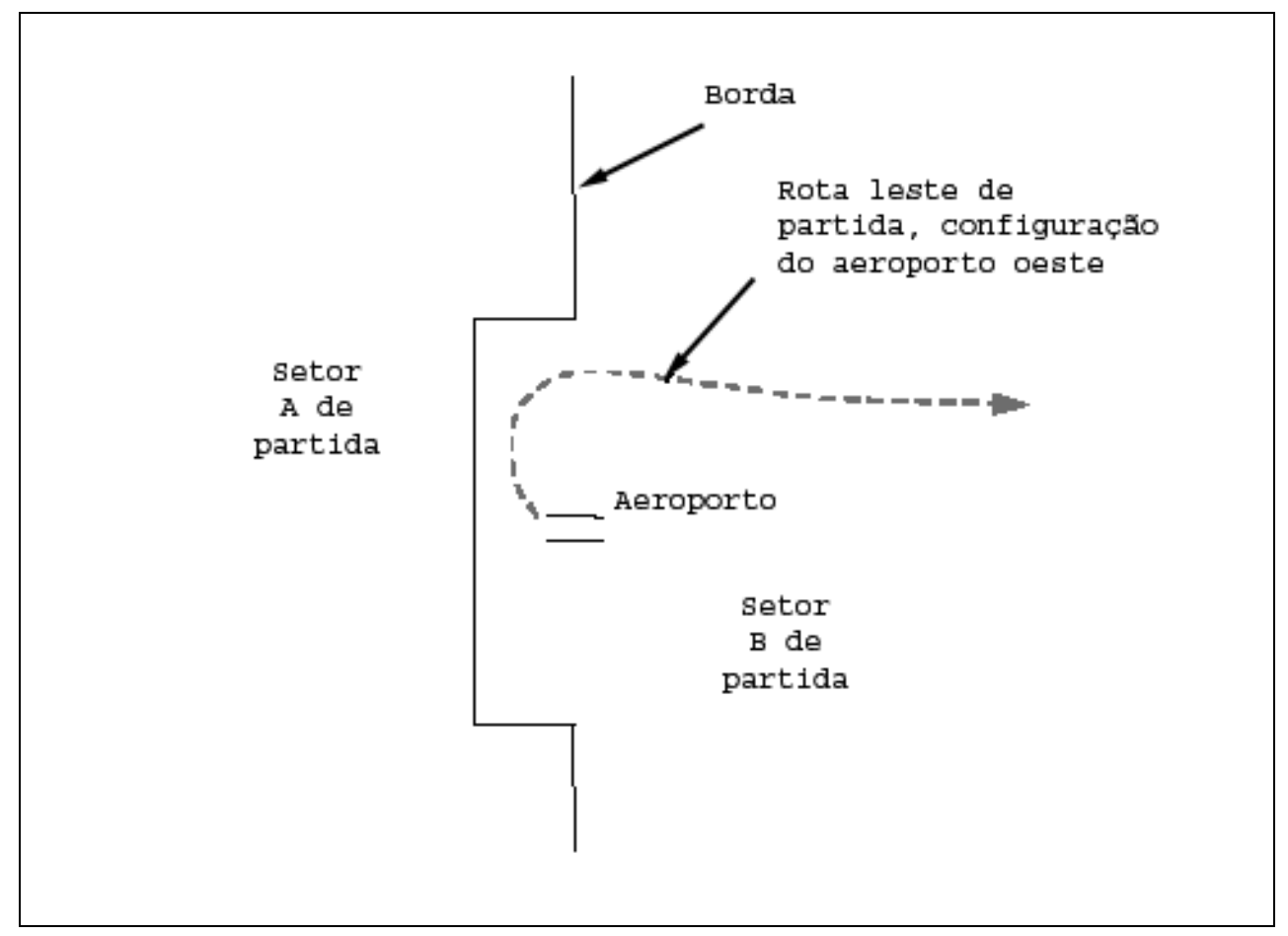

Figura 26 - Configuração genérica para operação Oeste (TABER, WOODWARD, SMALL, 2000).

Caso não existisse esse chaveamento entre essas configurações, uma possível forma de funcionamento para o aeroporto seria o apresentado na Figura 27, em que a borda que divide os setores A e B fica bem no meio da pista de decolagem. Assim, um avião que tivesse que decolar no sentido oposto a sua rota de partida iniciaria a decolagem em um setor e, depois de fazer o retorno para seguir a rota de partida, passaria para outro setor. O tempo para o avião decolar, fazer o retorno e seguir a sua rota de partida é relativamente muito curto. Com isso, o processo de coordenar a mudança do controle da aeronave entre setores, em um espaço de tempo curto, requer uma maior carga de trabalho dos controladores de tráfego aéreo, pois inicialmente o controlador nem bem assumiu o controle da aeronave e logo a seguir já tem que passá-la para o setor seguinte. Para tempos muito curtos essa tarefa não é recomendável.

O chaveamento entre as configurações Leste e Oeste, segundo o sentido de decolagem do avião, proporciona uma melhor gerência do controle de tráfego aéreo, equilibrando a carga de trabalho dos controladores de tráfego aéreo envolvidos. 


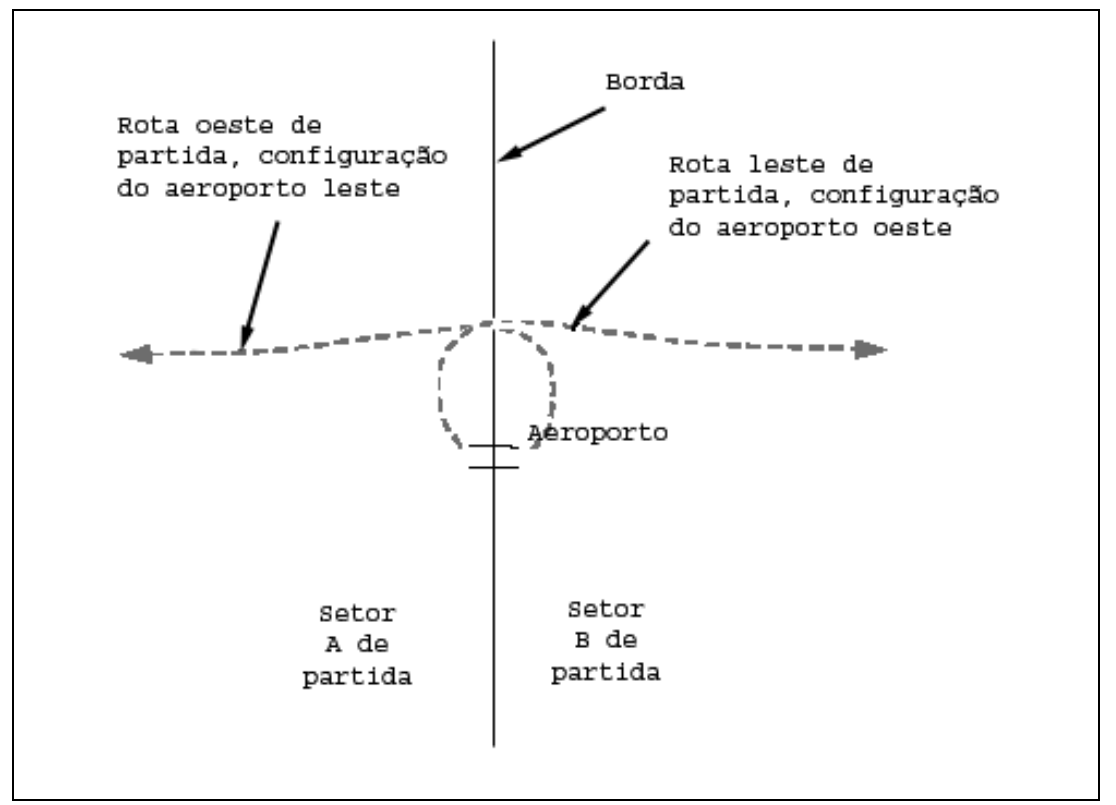

Figura 27 - Configuração genérica para operação Leste-Oeste (TABER, WOODWARD, SMALL, 2000).

A Figura 28 mostra a configuração dos setores na área terminal do aeroporto de Atlanta. A borda que separa os setores 16 e 04 fica bem no meio do aeroporto. Quando os ventos sopram do oeste, o aeroporto é configurado para as aeronaves decolarem no sentido oeste (essa é a configuração Oeste do aeroporto). O mesmo ocorre quando os ventos sopram do leste, gerando a configuração Leste do aeroporto.

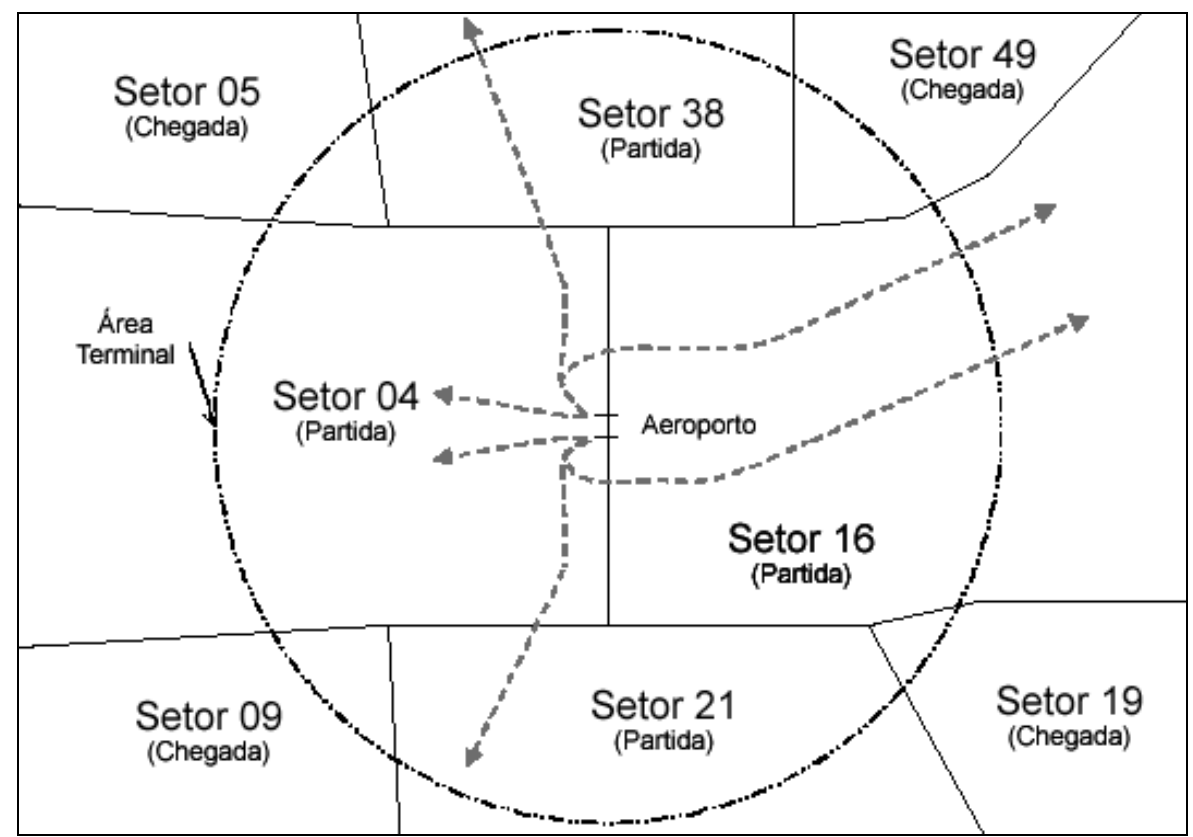

Figura 28 - TMA-Atlanta e Aeroporto de Atlanta (TABER, WOODWARD, SMALL, 2000). 
Na configuração Oeste do aeroporto, os aviões com rota para leste têm que decolar no sentido oeste e dar a volta para pegar a rota de sentido leste. Se não existir restrição de altura durante a subida, a aeronave entra em um setor do APP de Atlanta antes de terminar a volta e já passa para outro setor quanto acabar, pegando a rota de partida leste. Isso não acontece com os aviões que têm a rota de decolagem no sentido oeste, pois estes já decolam no mesmo setor que contém sua rota de partida.

Para diminuir a tarefa de coordenação entre os controladores para a transferência de aeronaves, as aeronaves que decolam no sentido oeste e fazem o retorno para pegar a rota de decolagem leste têm suas altitudes limitadas abaixo do controle do APP Atlanta, até que termine o retorno. Com isso estas aeronaves só entram no APP Atlanta quando estiverem em sua rota leste de partida. Com essa restrição, as aeronaves terão que manter certa altitude mais baixa por um tempo maior, levando mais tempo para atingir a altitude de cruzeiro. Como conseqüência, consumirão mais combustível e os tempos de vôo serão maiores.

Para melhor acomodar este problema, o APP Atlanta criou dois mapas que são chaveados segundo a configuração de operação do aeroporto. A Figura 29 mostra o mapa que é usado pelo APP Atlanta quando o aeroporto opera na configuração Oeste. As aeronaves que decolam no sentido oeste e fazem a volta para pegar sua rota no sentido leste realizam todas essas operações no mesmo setor. As demais aeronaves já decolaram no sentido correto, não precisando fazer o retorno, e vão ser controladas diretamente pelo setor do lado oeste.

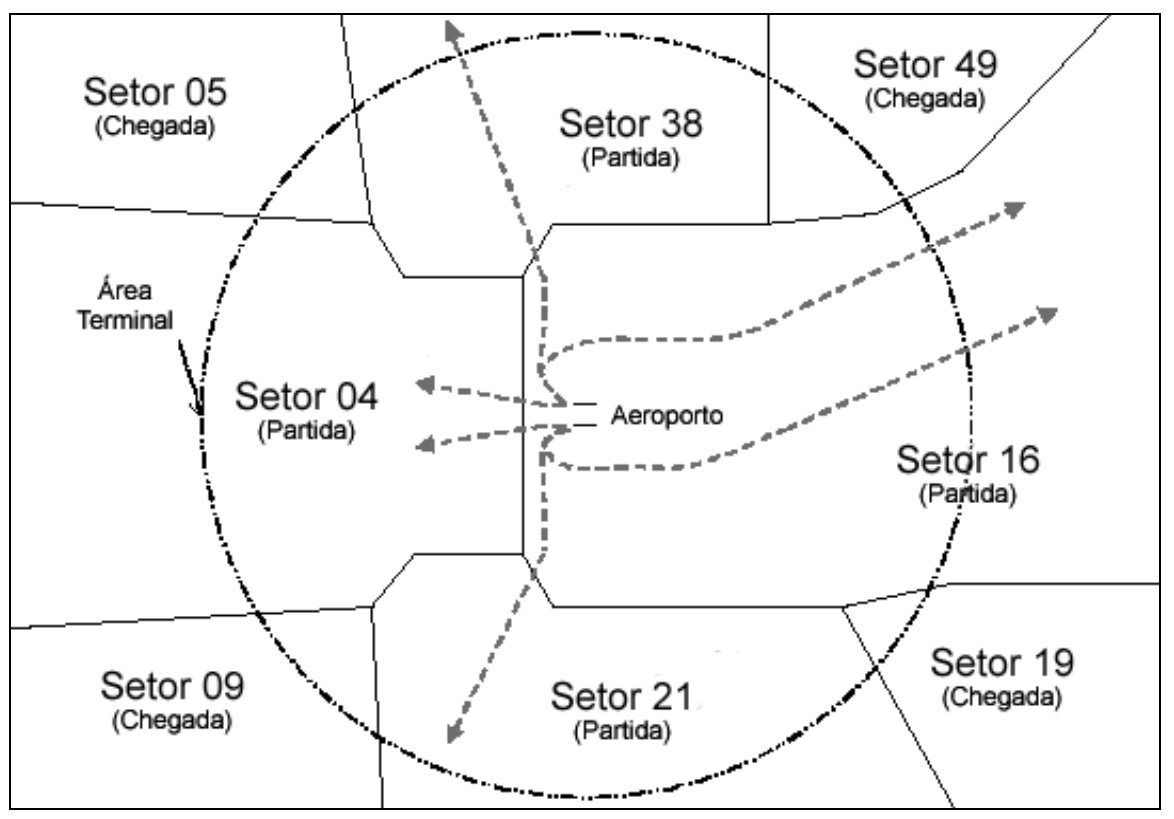

Figura 29 - Aeroporto de Atlanta na Operação Oeste (TABER, WOODWARD, SMALL, 2000). 
Na configuração de operação Leste do aeroporto, representada na Figura 30, o mesmo acontece como na configuração de operação Oeste. As aeronaves decolam e fazem todos os procedimentos em um único setor, tendo ou não que realizar o retorno para pegar a rota de partida.

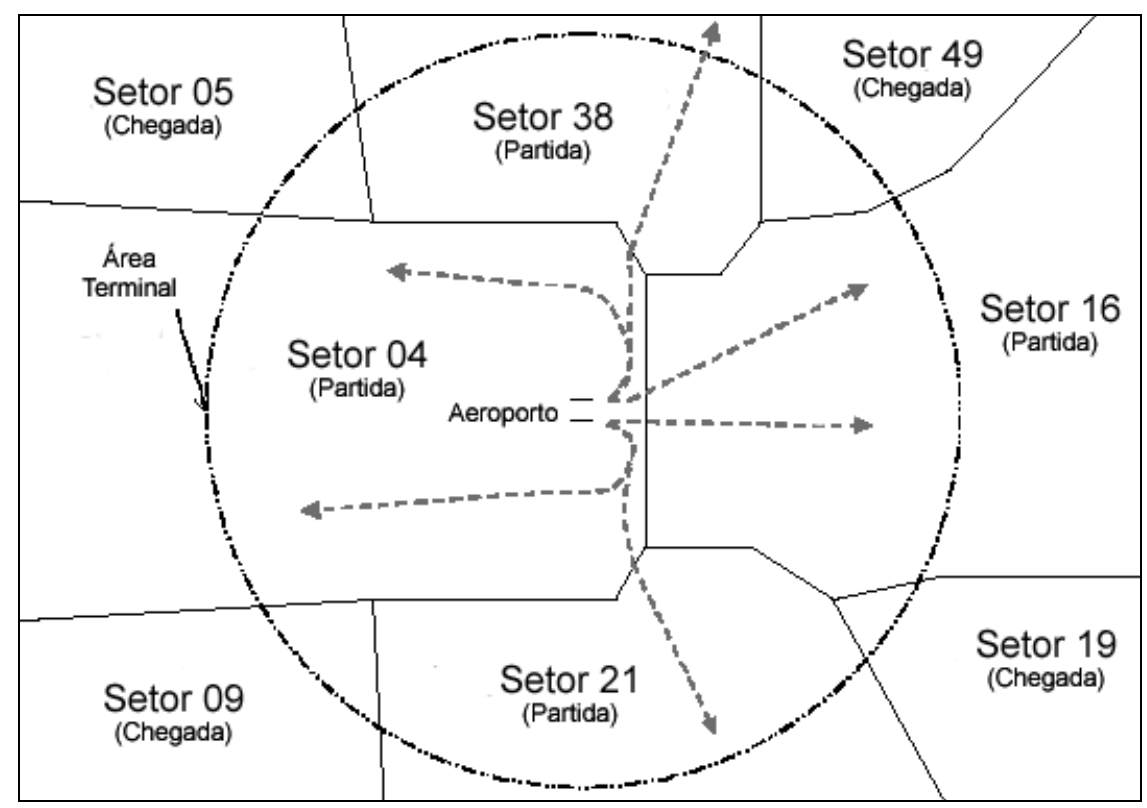

Figura 30 - Aeroporto de Atlanta na operação Leste (TABER, WOODWARD, SMALL, 2000).

Com a utilização da RDL por meio do chaveamento destes mapas, segundo a configuração de operação do aeroporto, as aeronaves não precisam obedecer a restrições mais severas e desnecessárias de altitude na decolagem, o que implicaria em maior gasto de combustível e maior tempo de vôo. Com esses procedimentos, não ocorre um acréscimo na carga de trabalho dos controladores de tráfego aéreo, pois não será mais necessária a coordenação de aeronaves que decolam em um setor e logo a seguir precisam ser transferidas para outro setor em um pequeno intervalo de tempo.

\subsubsection{Mudanças nas Rotas Oceânicas}

Os ventos e as rotas de aeronaves no oceano estão intimamente correlacionados. Uma mudança na trajetória dos ventos implica em uma re-configuração na direção norte-sul das rotas das aeronaves para melhor aproveitar o fluxo dos ventos. Dependendo da forma como é 
feita essa re-configuração, pode acarretar um aumento na carga de trabalho dos controladores de tráfego aéreo dos setores envolvidos. Para evitar esse acréscimo e manter a relação entre rotas e setores, visando evitar que uma rota fique mudando de setores diversas vezes, é necessário ajustar as bordas desses setores segundo a re-configuração das rotas. Com essa estratégia é possível reduzir o esforço de coordenação entre os controladores de tráfego aéreo de setores adjacentes e, conseqüentemente, as suas cargas de trabalho.

A Figura 31 mostra uma configuração genérica de rotas marítimas. Uma aeronave tem sua rota sempre contida em um único setor. Com a mudança dos ventos, essas rotas são retraçadas, o que pode fazer com que uma aeronave fique mudando constantemente de setor, e até mesmo retornando para um setor por onde ela já passou.

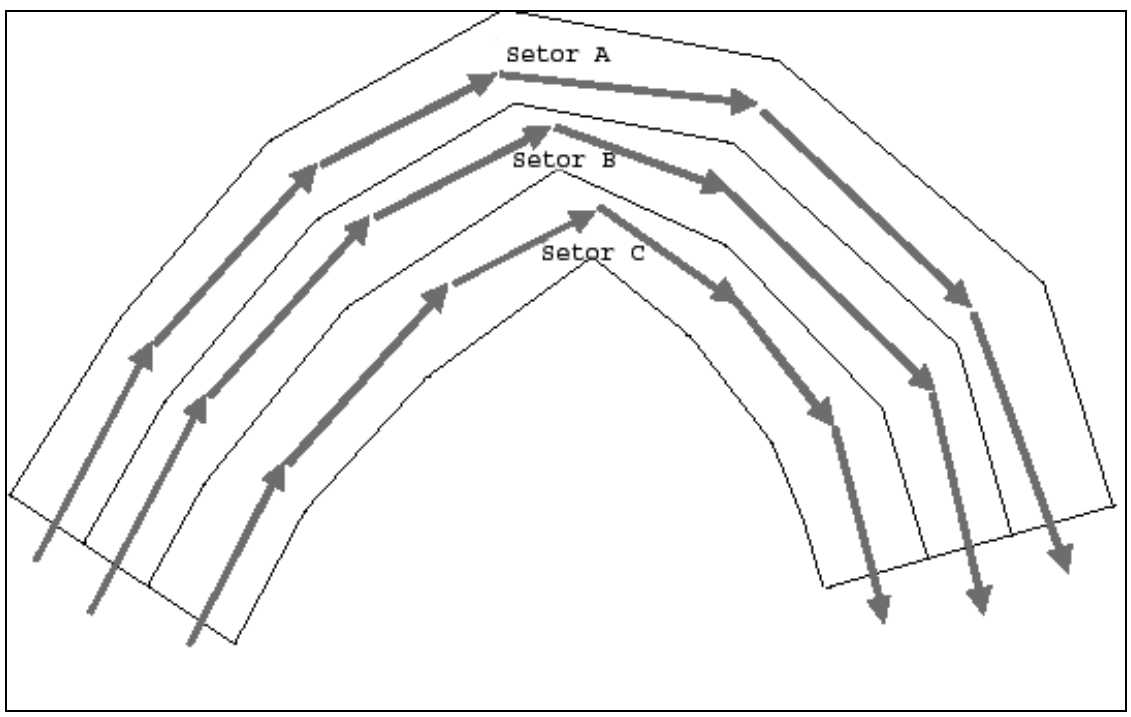

Figura 31 - Rotas oceânicas genéricas, nas configurações iniciais (TABER, WOODWARD, SMALL, 2000).

Uma forma de resolver esse problema é fazer com que as bordas dos setores acompanhem à re-configuração das rotas, com o objetivo de fazer com que uma rota fique sempre contida no mesmo setor, mesmo quando ela é re-configurada. A Figura 32 ilustra uma re-configuração das rotas (tracejado grosso) em que as bordas dos setores A, B e C são adaptadas a esta mudança (tracejado fino), gerando os novos setores A', B' e C'. 


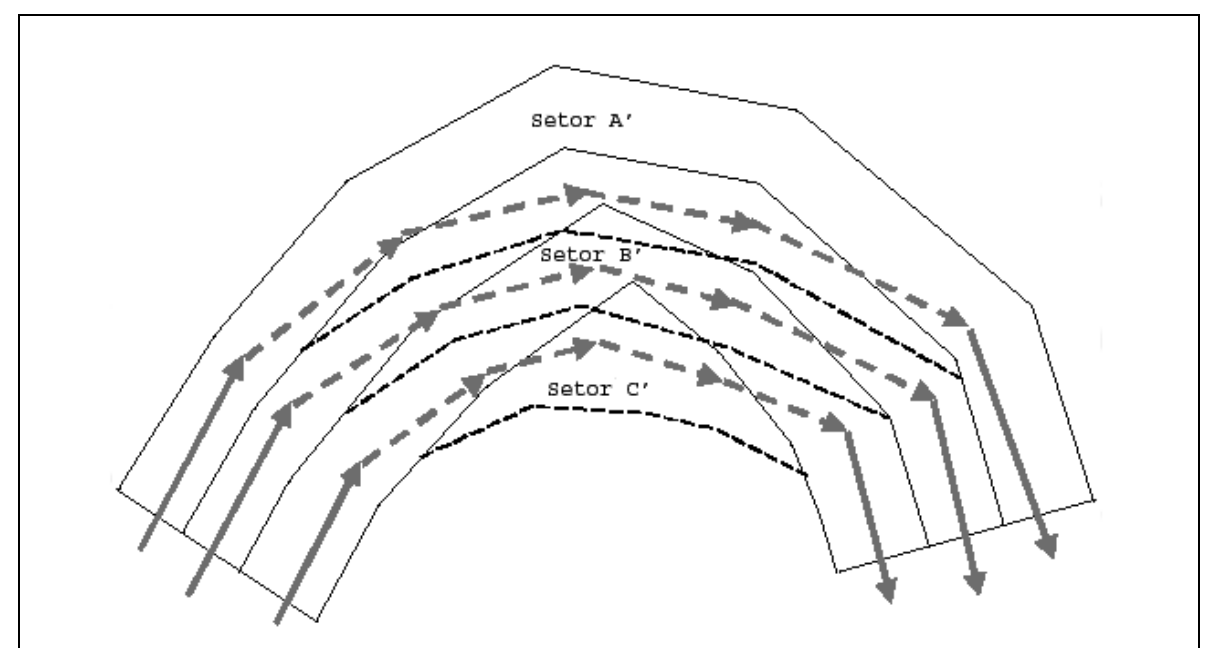

Figura 32 - Rotas oceânicas genéricas, nas configurações revisadas (TABER, WOODWARD, SMALL, 2000).

Um outro exemplo para acomodar as possíveis mudanças das rotas nos oceanos é mostrado na Figura 33. Ela ilustra duas rotas definidas no Centro de Oakland sobre o Oceano Pacífico. Com esta configuração, em que os setores são orientadas na direção norte-sul, as rotas I e F poderiam se mover no direção norte-sul, segundo as mudanças dos ventos, sem correr o risco de passar para um setor e depois retornar para o setor por onde já passou anteriormente. Contudo, essa configuração implica que um vôo sobre o oceano (direção leste-oeste) atravesse diversos setores durante o seu cruzeiro, requerendo, freqüentemente, maior coordenação entre controladores para cada vôo, aumentando a carga de trabalho dos controladores de tráfego aéreo envolvidos.

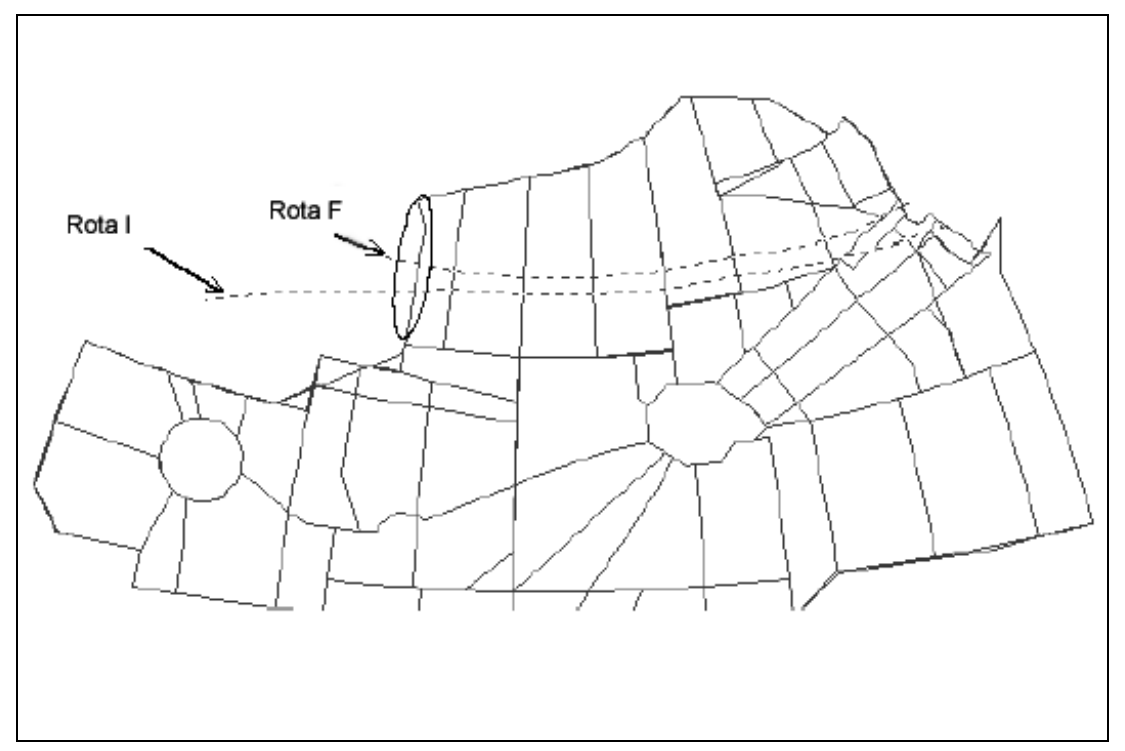

Figura 33 - Configuração de rotas oceânicas do centro de Oakland (TABER, WOODWARD, SMALL, 2000). 
Para melhor acomodar esse tráfego, o Centro de Oakland desenvolveu uma estratégia adaptativa dos setores, segundo a mudança das rotas. Os setores oceânicos, chamados de dynamic work areas, são configurados segundo a configuração das rotas. Com isso, uma mudança na direção dos ventos provoca uma re-configuração das rotas que cruzam em determinado ponto os antigos setores na direção norte-sul. A dynamic work area é definida a partir desses pontos de cruzamento em sentido longitudinal da rota. Assim, cada dynamic work area controla uma ou mais rotas durante toda a travessia do Oceano. Essa estratégia adaptativa proporciona uma redução na coordenação entre os controladores de tráfego aéreo e, conseqüentemente, uma diminuição da carga de trabalho durante o cruzeiro das aeronaves, pois uma aeronave não cruza vários setores durante o seu percurso oceânico.

\subsubsection{Uso Especial do Espaço Aéreo}

O uso especial do espaço aéreo para uma Área de Exclusão de Aeronaves e para uma Área de Operação Militar provocaria a reconfiguração de rotas, gerando um provável congestionamento aéreo e atrasos. Criar um novo setor como uma espécie de túnel através dessas áreas pode acomodar o congestionamento e reduzir a carga de trabalho dos controladores de tráfego aéreo envolvidos.

A Figura 34 e a Figura 35 mostram a criação de um "setor túnel" através da área de Uso Especial do Espaço Aéreo (SUA - Special Use Airspace) quando, por exemplo, os militares bloqueiam essa área para teste de lançamento de foguetes. Esse corredor é criado em negociação com os militares, possibilitando às aeronaves passarem por dentro da área de exclusão aérea sem causar maiores mudanças em suas rotas.

O espaço aéreo sobre o Oceano Atlântico, na costa leste do Centro de Jacksonville e Miami, tem uma área de exclusão aérea. Essa área é controlada pelo FACSFACJAX (Fleet Area Control and Surveillance Facility, Jacksonville Naval Air Station). Quando essa área é delegada para o Kennedy Space Center, as rotas no sudeste da Flórida são fechadas. As aeronaves são então forçadas a contornar essa área por terra, o que causa um congestionamento de aeronaves e um aumento na carga de trabalho dos controladores de tráfego aéreo da região. 


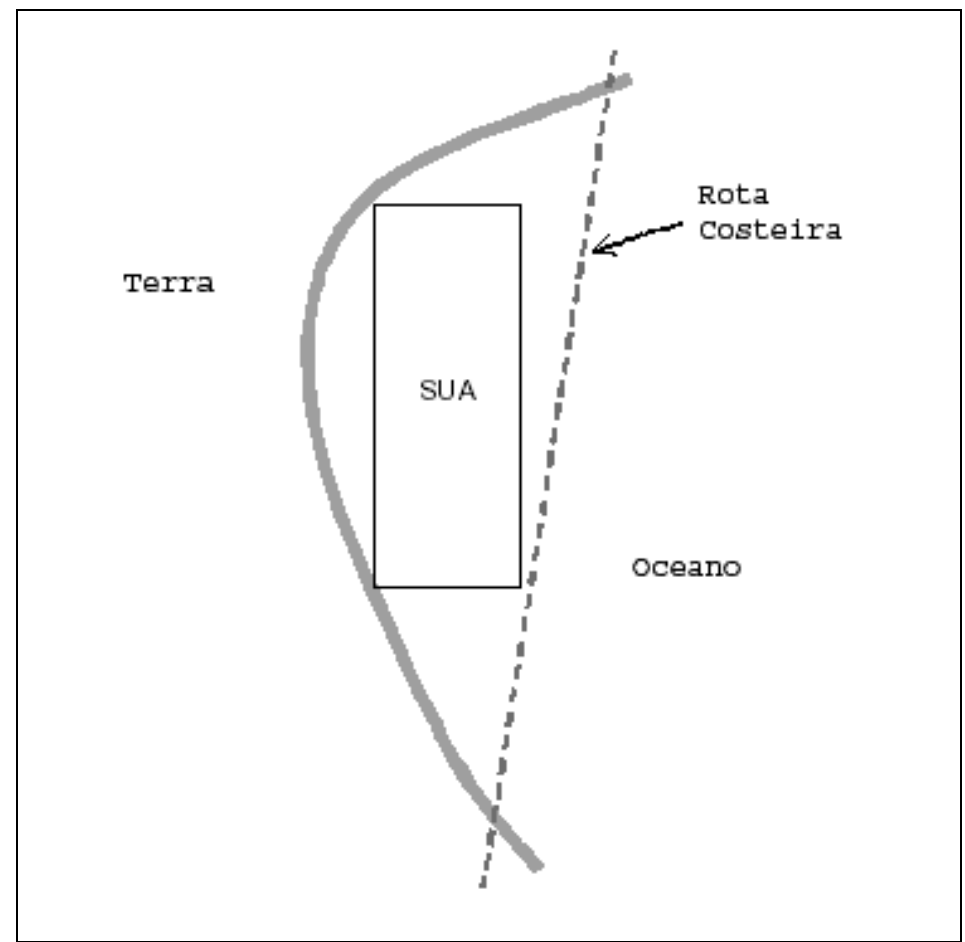

Figura 34 - Rota genérica passando ao lado de um espaço aéreo de uso especial (TABER, WOODWARD, SMALL, 2000).

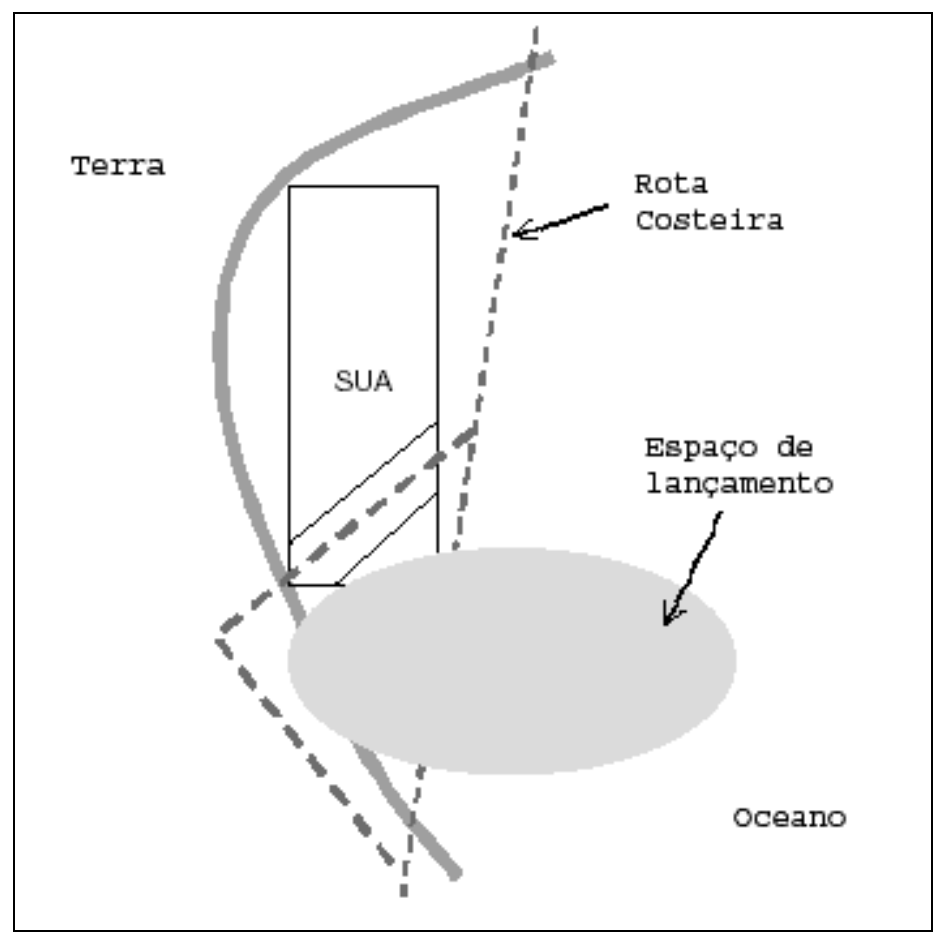

Figura 35 - Corredor genérico passando através de um espaço aéreo de uso especial (TABER, WOODWARD, SMALL, 2000). 
Para acomodar melhor esse tráfego, o Centro de Jacksonville negocia com FACSFACJAX e o Centro de Miami um corredor através da área de exclusão aérea quando as rotas dessa área são fechadas. A TORRY - Ormond Beach Corridor é o nome dado a esse corredor que fica sobre a coordenação do Centro de Jacksonville. Uma parte desse corredor que atravessa o Centro de Miami é então controlado pelo Centro de Jacksonville e fica restrito a esse Centro, quando essa área de exclusão for solicitada (vide Figura 36).

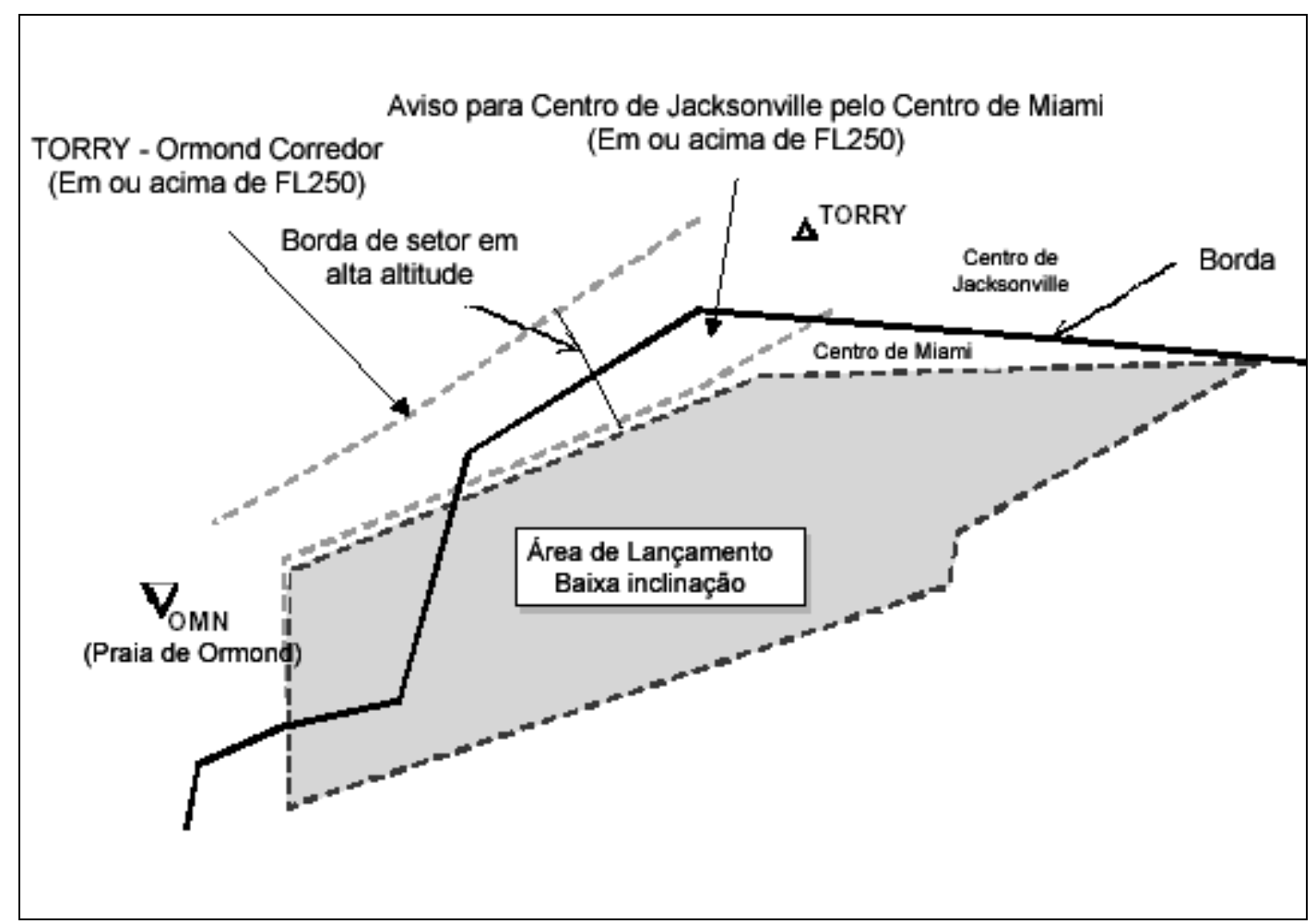

Figura 36 - Corredor da praia de Ormond - TORRY (TABER, WOODWARD, SMALL, 2000).

Para proporcionar a automação do uso do corredor TORRY, o Centro de Miami e Centro de Jacksonville desenvolveram novos mapas de seus setores, incluindo a área TORRY. Quando é negociada uma área de lançamento entre o Centro de Jacksonville e o FACSFACJAX, os mapas que mostram a área TORRY são chaveados no Centro de Miami e no Centro de Jacksonville, que assume então o controle do corredor TORRY. 


\subsubsection{Volume de Tráfego}

Nesta seção é explorado o uso da RDL de acordo com o volume de tráfego em um espaço aéreo. Um grande fluxo de aeronave sobre um setor pode ultrapassar a capacidade previamente definida de aviões suportada por este setor. Esse excesso provoca um aumento na carga de trabalho dos controladores de tráfego aéreo e atrasos devido ao congestionamento. Em contrapartida, uma baixa densidade de aeronaves em um setor, como por exemplo durante o período da madrugada, pouco aproveita a capacidade dos setores e, consequientemente, dos controladores do espaço aéreo.

E é exatamente neste ponto que a RDL pode ser útil. Dado uma configuração genérica de um setor, como a ilustrada na Figura 37, é possível acomodar um crescimento no fluxo de aeronaves no setor, dividindo-o em dois setores. Essa divisão faz com que não exista uma sobrecarga de trabalho do controlador, pois essa crescente demanda será gerenciada não mais por um único setor e um único controlador, mas sim por dois setores e dois controladores de tráfego aéreo.

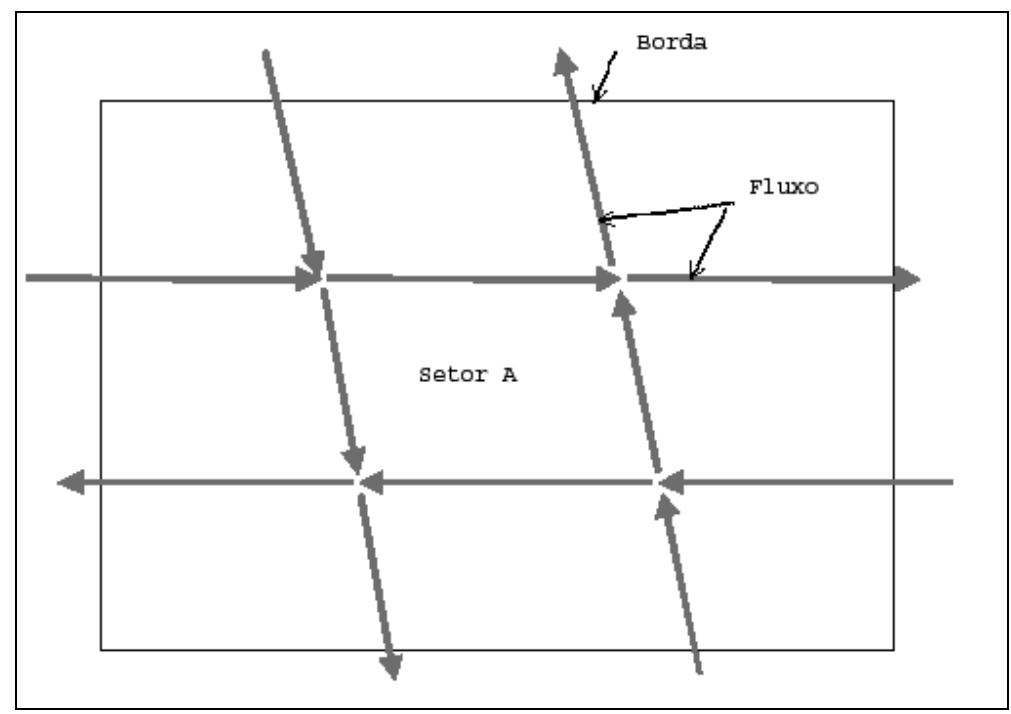

Figura 37 - Tráfego normal sobre uma configuração de um setor genérico (TABER, WOODWARD, SMALL, 2000).

A Figura 38 e a Figura 39 mostram a divisão do setor no sentido horizontal e vertical, de acordo com o crescimento do fluxo de aeronaves nessas direções, buscando manter as cargas de trabalho dos controladores de tráfego aéreo balanceadas. 


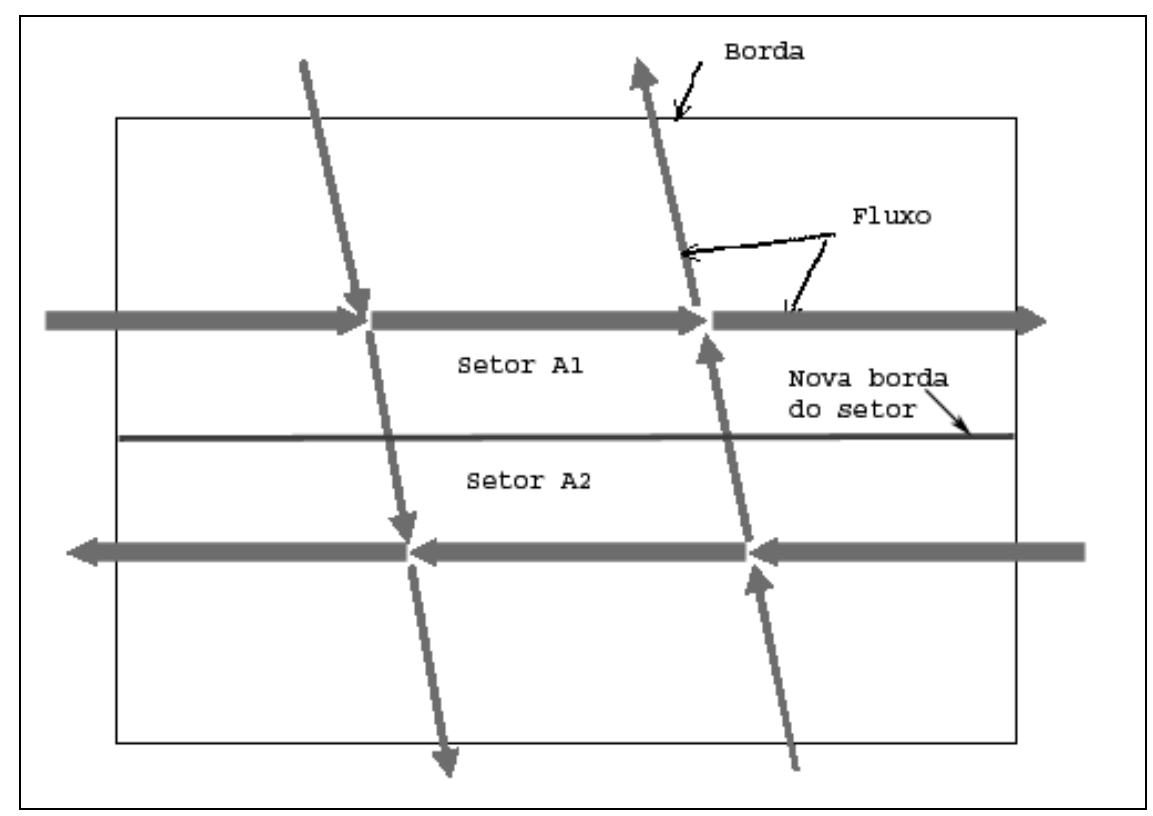

Figura 38 - Aumento do tráfego leste-oeste sobre uma configuração de um setor genérico (TABER, WOODWARD, SMALL, 2000).

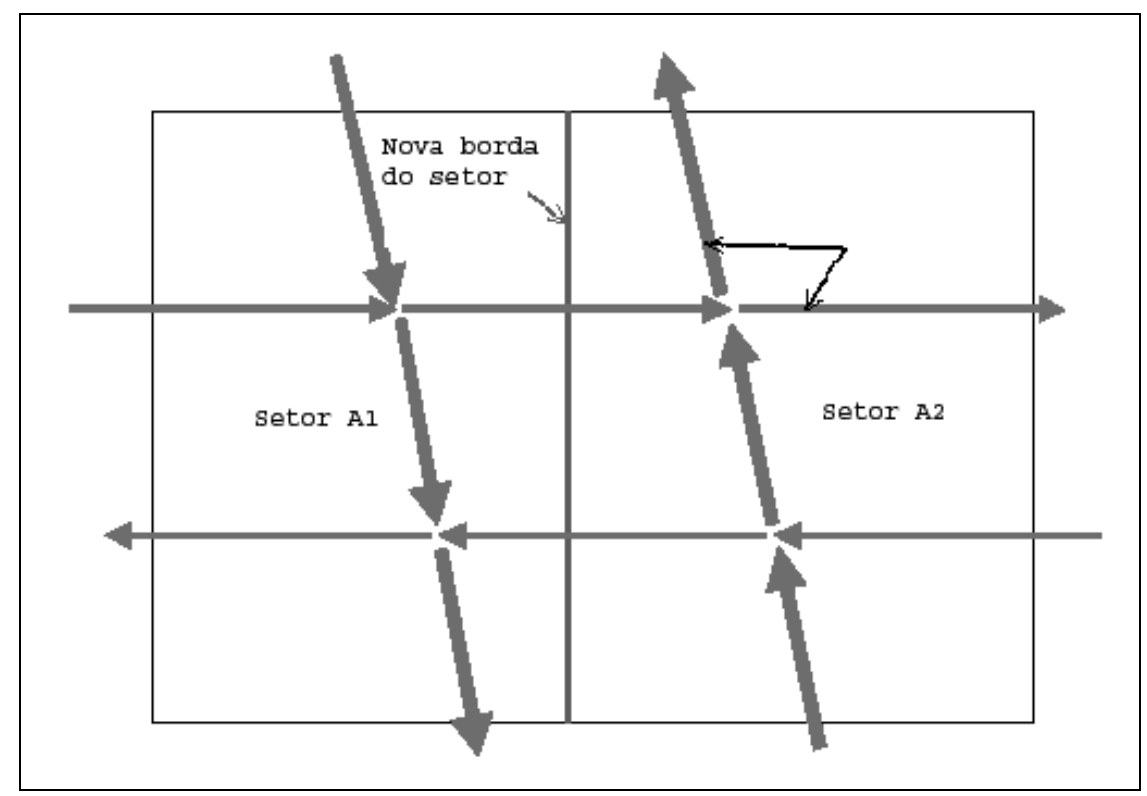

Figura 39 - Aumento do tráfego norte-sul sobre uma configuração de um setor genérico (TABER, WOODWARD, SMALL, 2000).

O Centro de Minneapolis tem uma configuração com setores grandes e largos. Constantemente este centro recebe um fluxo de aeronaves maior que o projetado para os seus setores. Uma forma que este Centro encontrou para não sobrecarregar seus controladores, devido a um maior fluxo de aeronaves nos setores, foi a utilização da RDL. 
A Figura 40 representa três grandes setores do Centro de Minneapolis (01, 02 e 03). Na figura, os dois primeiros números representam o setor e os dois últimos as FPAs (Fix Posting Areas). Exemplificando, 0305 e 0307 são as FPAs 05 e 07 do setor 03. O conceito de FPA é aplicado ao espaço aéreo dos Estados Unidos da América onde os setores são formados por blocos indivisíveis que recebem o nome de FPA. Estes blocos são agrupados em uma forma de "quebra-cabeça" para formar os setores.

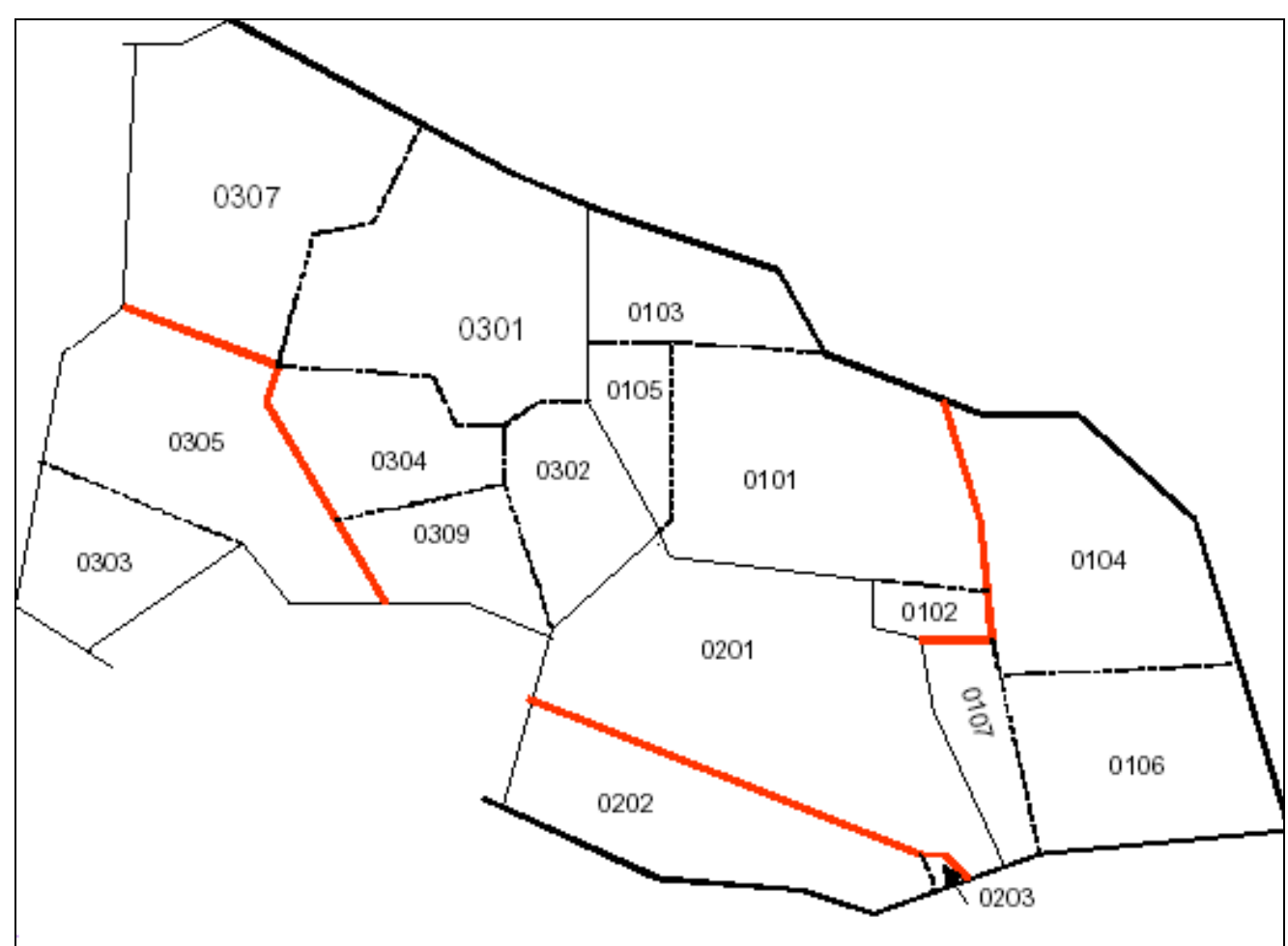

Figura 40 - Configuração dos setores 01, 02 e 03 do Centro de Minneapolis e suas FPAs (TABER, WOODWARD, SMALL, 2000).

As linhas vermelhas da Figura 40 representam bordas de divisão de setores quando existe uma alta densidade de aeronaves neste espaço. Assim, as FPAs 0305 e 0303 são agrupadas para formar um novo setor e as FPAs 0301, 0302, 0304, 0307 e 0309 passam a formar outro novo setor. Assim, o setor 03 ficou divido em dois novos setores. O mesmo acontece para os setores 01 e 02 , também divididos em dois novos setores cada um.

Seguindo esses procedimentos, o Centro de Minneapolis consegue acomodar uma demanda maior de aeronaves em seu espaço aéreo sem sobrecarregar a carga de trabalho de cada um dos seus controladores de tráfego aéreo e sem causar atrasos no sistema. 


\subsection{Considerações a Respeito da Re-setorização Dinâmica}

Durante a investigação deste trabalho de pesquisa foi possível perceber que os Estados Unidos vêm tratando com muita atenção a RD, ao contrário da Europa. A NASA (National Aeronautics and Space Administration), a FAA (Federal Aviation Administration) e o MIT (Massachusetts Institute of Technology) apresentam algumas pesquisas e referências sobre este tema, enquanto poucas existem provenientes do EUROCONTROL (European Organisation for the Safety of Air Navigation). Conforme mostrado neste capítulo, a RD já vem sendo usada nos Estados Unidos.

Um ponto importante que facilita o uso da RD no espaço aéreo dos Estados Unidos é que este espaço foi estruturado e concebido com o conceito de "células atômicas indivisíveis" que se combinam para formar os setores. Estas células, no espaço aéreo dos Estados Unidos, são chamadas de FPAs (Fix Posting Areas). Como ilustrado na Figura 40, o uso do FPA facilita a re-configuração dos setores em um espaço. Elas funcionam como peças de um "quebracabeça" que vão se encaixando para forma a configuração dos setores. Para mudar a configuração dos setores, basta re-arranjar as FPAs.

Uma visão importante sobre a RD é a sua relação com o fator humano dos controladores de tráfego aéreo. Em outras palavras, a questão de como a RD afeta o desempenho dos controladores de tráfego aéreo e qual a sua relação com carga de trabalho desses controladores. Handley (2000) e Stein, Rocco e Sollenberger (2005) chegaram a conclusão que o uso da RD não interfere na performance dos controladores e diminui a sua carga de trabalho em comparação com um cenário sem a RD.

Contudo, Wilhelmsen (1999a e 1999b) e Pawlak (1997) consideram cinco pontos que devem ser explorados no uso da RD:

a) O primeiro ponto é que os procedimentos para chaveamento das configurações dos setores precisam ser bem planejados a fim de proporcionar uma transição tranqüila entre configurações de setores. Ainda, todos os chaveamentos entre configurações têm que seguir um planejamento, gerando notificação claras para todos os envolvidos nesse processo;

b) O segundo ponto, de suma importância, diz respeito à freqüência de chaveamento entre as configurações dos setores no espaço aéreo e ao momento de se efetuar os chaveamentos de uma configuração para outra. Segundo Pawlak (1997), a 
freqüência com que a configuração do espaço aéreo é chaveada precisa ser analisada juntamente com a complexidade do tráfego aéreo. Quanto mais complexo for o tráfego aéreo, menor deve ser a freqüência de mudanças na configuração do espaço aéreo. Realizar mudança freqüentes na configuração do espaço aéreo com um tráfego complexo influencia negativamente a carga de trabalho do controlador de tráfego aéreo. Já o momento em que deve ocorrer o chaveamento depende muito da aplicação da RD. Para cada caso de indisponibilidade de equipamentos, mudanças climáticas, uso especial do espaço ou volume de tráfego deve existir um procedimento para se chegar ao momento de chaveamento;

c) O terceiro ponto abordado é que as novas configurações dos setores de um espaço aéreo precisam ser pré-definidas com antecedência, possibilitando um adequado reconhecimento e treinamento dos controladores de tráfego aéreo com esses novos cenários. Isso faz com que os controladores tenham maior familiaridade com as possíveis configurações dos setores que eles vão controlar;

d) $\mathrm{O}$ quarto ponto estabelece que o número de configurações possíveis para cada espaço aéreo é limitado pelo número de radiofrequiências disponíveis para comunicação entre pilotos e controladores. Para cada setor do espaço deve se ter uma freqüência disponível para comunicação entre piloto e controlador. Contudo, esse número de freqüências é limitado; e

e) Por fim, o quinto ponto de alerta é que deve ser empregado o uso de automação para acomodar as mudanças de cenários de controle do espaço aéreo, minimizando a necessidade de procedimentos de coordenação entre controladores.

\subsection{Considerações Finais do Capítulo}

Esse capítulo é a base teórica da Re-setorização Dinâmica (RD) deste trabalho de investigação científica. Nele foram apresentados os conceitos da RD, da RD Limitada (RDL), da RD Irrestrita (RDI) e as principais diferenças entre a RDL e a RDI. Foram exemplificados, ainda, seis casos de uso da RDL, que já é uma realidade no controle de tráfego aéreo nos Estados Unidos. O capítulo foi finalizado com uma análise mais crítica sobre a RD e algumas considerações a respeito da sua aplicabilidade. 


\section{Estudo de Caso}

Este capítulo tem como objetivo apresentar os estudos de caso que são investigados neste trabalho de pesquisa. No Capítulo 3 são apresentadas algumas situações em que é recomendado o uso da RDL. $\mathrm{O}$ foco deste trabalho é investigar, por meio de simulações computacionais, o uso da RDL devido a variações do volume de tráfego aéreo. Apesar da RDL ser aplicável ao espaço aéreo controlado pelos três centros de controle de tráfego aéreo, ACC, APP e TWR, este trabalho especificamente aborda a aplicação da RDL na TMA sobre o controle do APP.

\subsection{Os Processos Envolvidos na Re-setorização Dinâmica}

O diagrama da Figura 41 ilustra os macros processos da RD (WILHELMSEN et al., 1999a). A caixa (1) representa o processo que monitora o sistema de tráfego aéreo e prediz possíveis crescimentos da carga de trabalho. As variáveis analisadas são baseadas na expectativa de crescimento da demanda do tráfego aéreo, nas alterações climáticas e em outros fatores.

Quando essa predição indica uma variação considerável na carga de trabalho (A), novas configurações dos setores que melhor atendam a essa situação são selecionadas/desenhadas, buscando-se um equilíbrio na carga de trabalho do controlador de tráfego aéreo (2).

Após se determinar as novas configurações dos novos setores, os mesmos são validados para que seja garantida que a sobrecarga de trabalho dos controladores de tráfego aéreo, prevista em (1), tenha sido sanada (B). O instante de ativação desses novos setores são então calculados e ajustados. Notificações e instruções para o chaveamento da nova configuração são geradas e repassadas para todos os envolvidos no processo (3). Alcançado o instante para a ativação dos novos setores, e após o cumprimento de todas as instruções determinadas em (C), são ativados os planos de chaveamento dos novos setores e executadas as atividades de transição (4). Terminados todos os procedimentos descritos, o ciclo se repete, retornando ao processo (1). 
(D) Continuar normalmente a operação com os novos setores configurados.

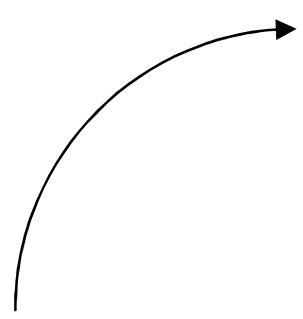

\section{Operação normal} do Sistema: monitoração das aeronaves; predição de variação considerável do tráfego, de mudanças climáticas e da carga de trabalho do controlador.
(A) Detecção de sobrecarga ou subcarga de aeronaves nos setores e variação considerável da carga de trabalho dos controladores.
Ativar os plano

de chaveamento para

novos setores e executar

as atividades de transição.
Determinar e avaliar as novas bordas dos setores.

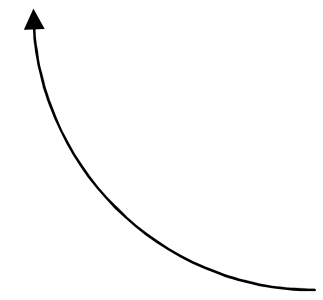

(C) Instruções completadas e tempo de ativação alcançado.
Sincronizar o tempo de ativação, gerar notificações, instruções dos procedimentos de préativação.

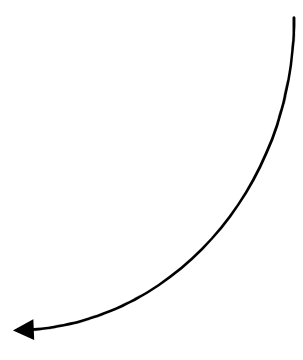

(B) Novos setores determinados e avaliados.

Figura 41 - Diagrama com estados e processos da re-setorização dinâmica (WILHELMSEN et al., 1999a). 
Esse é o ciclo geral da RD que pode ser usado tanto na RDL como na RDI. O ponto inicial do processo da RDL é definir o espaço aéreo e os setores que serão foco da análise. Dado esse espaço, o histórico do fluxo de aeronaves nos seus setores e levando-se em consideração o conhecimento e a experiência das pessoas envolvidas no Controle de Tráfego Aéreo, é possível, por meio de simulações computacionais, estimar a carga de trabalho de cada controlador de tráfego aéreo por período de tempo. Esse fluxo representa a fase (1) e a transição (A) da Figura 41.

Sempre que existir um desbalanceamento significativo de carga de trabalho entre setores do espaço aéreo, na forma de uma subcarga ou de uma sobrecarga de trabalho relativas entre os setores desse espaço aéreo, pode-se efetuar rearranjos nos setores que busquem equilibrar novamente a carga de trabalho dos controladores.

Determinadas as novas configurações do espaço aéreo, é preciso validar se essa nova configuração equilibra a carga de trabalho dos controladores. Uma forma de se fazer essa validação é submeter esses novos cenários a um software de simulação e comparar a sua resposta para as cargas de trabalho dos controladores, antes e depois da re-setorização. É importante que seja mantido sempre o mesmo fluxo de aeronaves para todas as simulações. Essa etapa representa a fase (2) e a transição (B) da Figura 41.

O processo de chaveamento dos mapas com as configurações dos setores descrito na fase (3) é muito importante. Saber o momento certo de chaveamento e a frequiência com que ocorre o chaveamento não é uma tarefa tão simples. O excesso de chaveamento de setores aumenta a carga de trabalho dos controladores, pois além destes terem que lidar com o trafego aéreo, terão que lidar com um cenário de constante mudança. Outro ponto importante para não causar estresse exagerado nos controladores de tráfego aéreo é um conhecimento prévio de todos os cenários possíveis de re-setorização. Quanto maior a familiaridade dos controladores com os possíveis arranjos dos setores, maior será a facilidade de chaveamento entre setores (WILHELMSEN et al., 1999b; HADLEY et al., 2000; STEIN, ROCCO, SOLLENBERGER, 2005).

Neste trabalho de pesquisa, por intermédio de simulações computacionais, é apresentado um estudo relacionado com as fases (1), (2) e (3), incluindo as transições (A) e (B), tendo como base o conceito da RDL: a) são definidos o espaço aéreo e os setores que fazem parte da análise e são calculadas as cargas de trabalho dos controladores de tráfego aéreo, sem o uso da RDL, referentes a (1) e (A); b) são propostas novas configurações do espaço aéreo e os seus 
momentos de chaveamento, baseadas na RDL, referentes a (B), (2) e (3); c) é analisado o impacto do uso da RDL no espaço aéreo investigado.

\subsection{Um Breve Panorama da Re-setorização Dinâmica}

O objetivo da Re-setorização Dinâmica (RD) é criar algumas configurações constituídas de um conjunto de setores, usando como base o estudo do tráfego aéreo nestes setores e levando em consideração o conhecimento e a experiência das pessoas envolvidas no Controle de Tráfego Aéreo. Dado um conjunto de setores e o fluxo de aeronaves, é possível, por meio de ferramentas computacionais, propor a união, a quebra ou a redefinição destes setores, devido a uma alta variação da densidade de aeronaves nesses setores.

A Figura 42 mostra um espaço aéreo hipotético com uma configuração estática de quatro setores (A, B, C e D). Uma sobrecarga de aeronaves em um determinado setor pode ocasionar um aumento na carga de trabalho dos controladores envolvidos. Uma forma de diminuir a carga de trabalho é fazer uma RD deste espaço aéreo, gerando novas configurações das fronteiras dos setores. Essa RD pode ser elaborada conforme os exemplos a seguir.

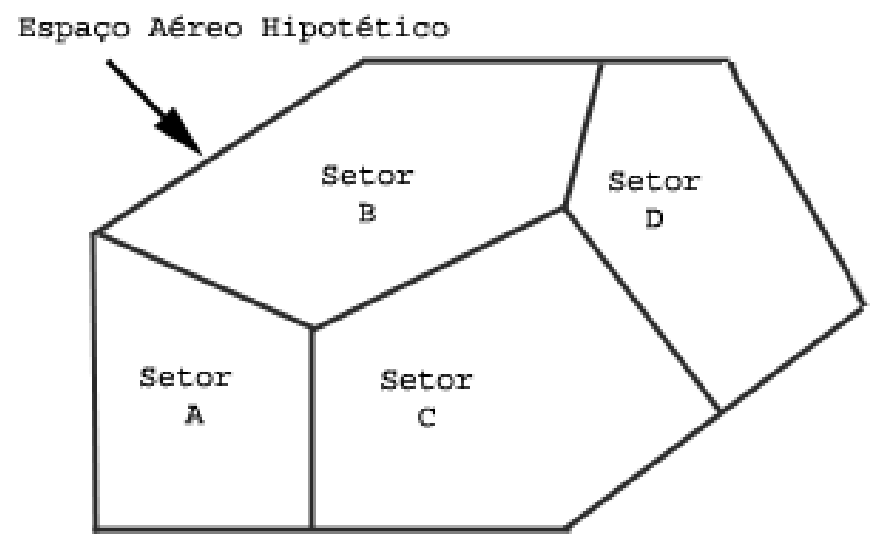

Figura 42 - Espaço aéreo hipotético setorizado.

A Figura 43 ilustra uma possível re-setorização do espaço aéreo, que apenas redefine as bordas dos setores do espaço aéreo mostrado na Figura 42. Nesta RD são feitos alguns ajustes 
nas bordas dos setores para melhor distribuir as rotas de aeronaves dentro destes novos setores e melhor balancear a densidade de aeronaves neles presentes.

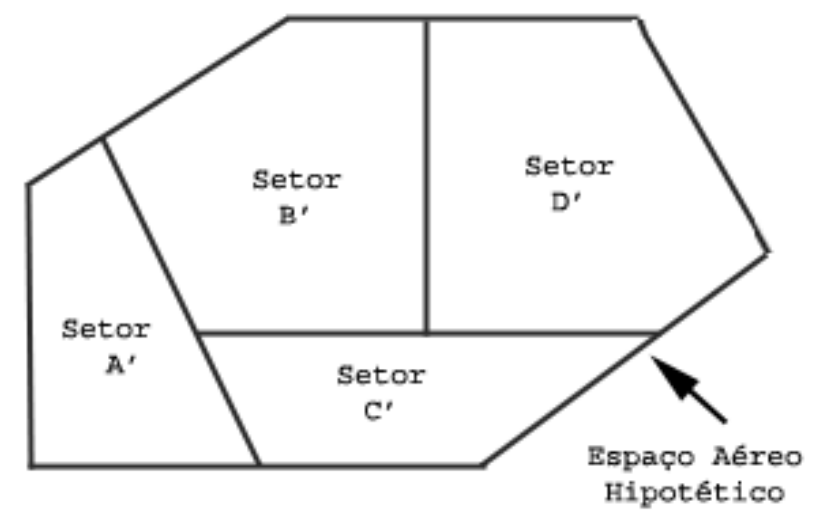

Figura 43 - Re-setorização apenas redefinindo as bordas dos setores existentes.

Outro possível caso de re-setorização é obtido mantendo-se a configuração das bordas entre os setores adjacentes, mas dividindo internamente determinados setores. Isso pode ocorrer, por exemplo, devido a um aumento da densidade de aeronaves em um determinado setor, o que pode acarretar um aumento da carga de trabalho do controlador daquele setor. A Figura 44 ilustra uma possível re-setorização devido a um aumento da carga de trabalho dos controladores dos setores B e C, cujas configurações originais foram mostradas na Figura 42. Nesse caso, o setor B deu origem a dois novos setores, B1 e B2, enquanto o setor C deu origem aos novos setores $\mathrm{C} 1$ e $\mathrm{C} 2$. 


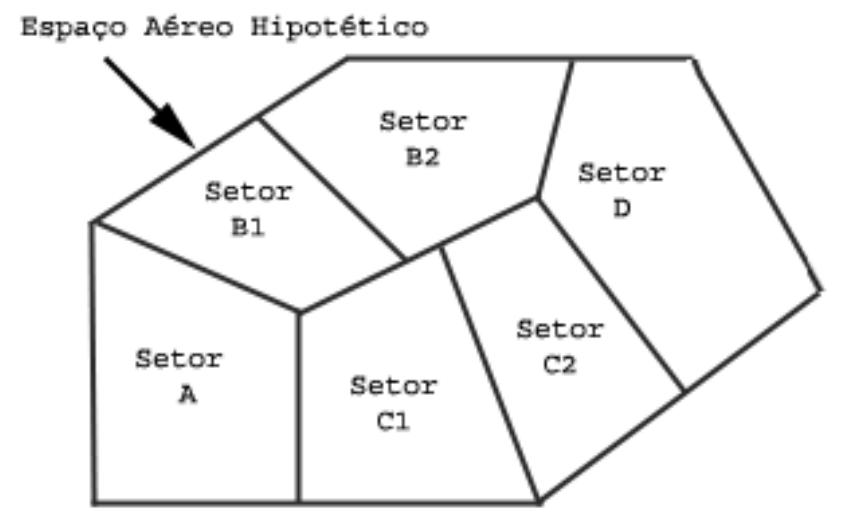

Figura 44 - Re-setorização com a divisão de alguns setores.

Caso exista uma baixa carga de trabalho em dois setores adjacentes, estes setores podem ser agrupados, formando um único setor. Essa re-setorização pelo agrupamento de setores é ilustrada pela Figura 45, onde os setores originais B e C mostrados na Figura 42 foram agrupados em um novo setor B, enquanto o setor D foi renomeado para setor C.

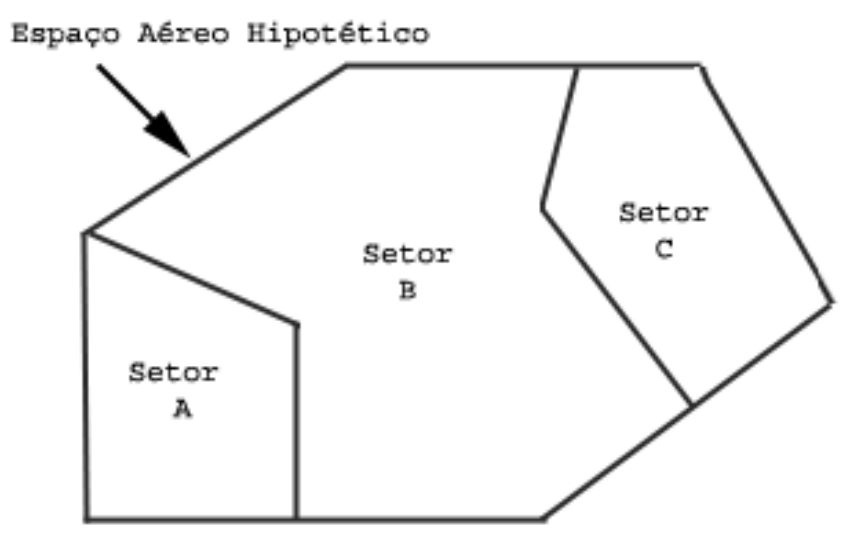

Figura 45 - Re-setorização com o agrupamento de alguns setores. 
Todos esses exemplos apresentados foram ilustrados separadamente para uma melhor compreensão das diversas técnicas de re-setorização possíveis, mas que, eventualmente, podem ser combinados em uma única RD do espaço aéreo.

\subsection{O Software Utilizado para Simulação}

O software de simulação de tráfego aéreo utilizando nesta pesquisa foi o RAMS Plus (RAMS - Reorganized ATC Mathematical Simulator) (RAMS, 2005). Este software foi desenvolvido pela ISA Software com o objetivo de promover, por meio de simulações, estudos e análises da infra-estrutura utilizada nos aeroportos e nos sistemas de Controle do Tráfego Aéreo (ATC), incluindo todos os seus órgãos (ACC, APP e TWR).

Com ele é possível modelar uma infra-estrutura aeronáutica com aeroportos de partida e de chegada, com seus respectivos horários dos vôos, tipos de aeronaves utilizadas, rotas seguidas, nível de cruzeiro de vôo, velocidade desenvolvida pela aeronave, número de controladores responsáveis pelo controle de cada setor, dentre outras variáveis.

As ferramentas disponíveis nesse software de simulação são:

a) Setorização 4D (três dimensões espacial mais o tempo): a ferramenta permite desenhar um espaço aéreo tridimensional e dividi-lo em setores. É possível, também, definir vários tipos de configurações do espaço aéreo com seus setores, bem como chavear essas configurações no tempo, ou seja, utilizar a RDL;

b) Geração de tráfego estocástico: além de permitir a inclusão e configuração de tráfego específico para ser usado durante as simulações sobre o cenário desenhado, a ferramenta também permite gerar um tráfego aleatório de aeronaves e utilizar este tráfego sobre um dado cenário;

c) Detecção de conflitos espaciais: a detecção de conflitos é aplicada aos vôos considerando a separação mínima definida para o espaço aéreo. A ferramenta monitora os vôos durante a simulação e verifica se existiu uma violação da separação mínima pré-estabelecida; 
d) Resolução de conflitos utilizando técnicas de inteligência artificial: quando é detectado um conflito entre duas aeronaves durante a simulação, a ferramenta busca, por meio de regras já definidas, a resolução deste conflito. Existe a possibilidade de se modificar essas regras e até utilizar um módulo de resolução de conflitos manual (o usuário, neste caso, interage com o sistema quando um conflito é detectado). Durante as simulações realizadas nesta investigação foi desativado o módulo de resolução de conflito do RAMS Plus. Quando este módulo era ativado, a simulação "travava" e o software parecia que entrava em um laço (loop) infinito. Isso pode ter ocorrido devido ao grande volume de aeronaves utilizado nas simulações;

e) Cálculo de carga de trabalho: com este software é possível associar aos eventos relativos ao controle de tráfego aéreo as tarefas realizadas por um controlador de tráfego. Cada uma dessas tarefas recebe um peso que pode ser associado ou não ao tempo médio que o controlador demora para cumprir a tarefa. Antes da simulação são planejadas as tarefas que devem ser realizadas pelos controladores de tráfego aéreo. Por exemplo, antes de um avião decolar, o piloto deve pedir permissão para um controlador da torre de controle. Durante a simulação são armazenadas todas as tarefas realizadas pelos controladores, quem realizou a tarefa e o peso definido para cada tipo de tarefa definida. Com esses dados é possível calcular qual a carga de trabalho total dos controladores de tráfego aéreo envolvidos na simulação;

f) Modelagem de TWR, APP, ACC e suas aerovias: com essa ferramenta é possível criar diversos cenários modelando os órgãos do Controle de Tráfego Aéreo, criando aerovias, definindo SIDs (Standard Instrument Departures) e STARs (Standard Arrival Routes), configurando rotas e pontos fixos. Esses cenários podem ser usados em simulações com qualquer tipo de tráfego; e

g) Movimentação na TMA e em seus aeroportos, incluindo alocação de gates e gerenciamento de operações de taxiamento: o RAMS Plus permite não só realizar simulações aéreas, como também estudar como o fluxo de aeronaves influencia na infra-estrutura aeronáutica de um aeroporto e qual a melhor configuração para esse aeroporto em relação ao seu tráfego de aeronaves. Com essa ferramenta é possível modelar os mais diversos tipos de aeroportos, definindo suas pistas e alocação de gates para as aeronaves, bem como gerenciar as operações de taxiamento relacionadas às operações de pousos e decolagens e aeronaves. 
Todas essas ferramentas contam com o auxílio de gráficos e animações visuais para os cenários simulados. A Figura 46 ilustra a tela do software RAMS Plus para uma simulação da TMA-SP.

Na Figura 46 pode-se observar o software RAMS Plus que disponibiliza uma interface gráfica para a construção dos cenários utilizados nas simulações. Neste caso, encontra-se ilustrado um cenário da TMA-SP utilizado nas simulações desta investigação científica.

Essas simulações possibilitam detectar possíveis conflitos, aplicar conceitos atuais e futuros de controle de tráfego aéreo e mensurar qual a carga de trabalho de um controlador de tráfego aéreo, considerando um determinado tráfego e uma determinada infra-estrutura previamente estabelecida.

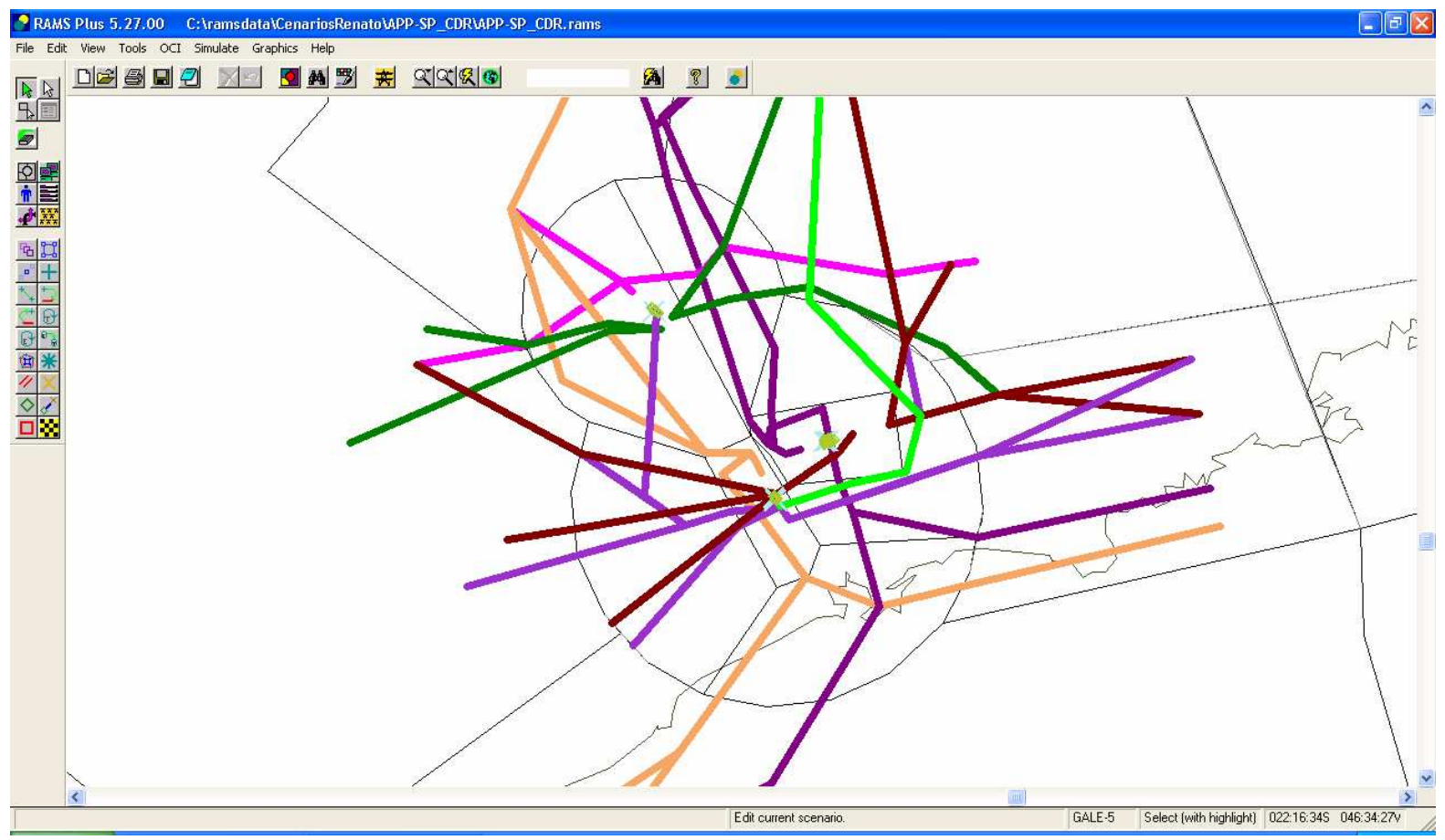

Figura 46 - Tela do software RAMS Plus.

Neste trabalho são utilizadas as seguintes ferramentas do RAMs Plus:

- Setorização 4D;

- Detecção de conflitos espaciais;

- Cálculo da carga de trabalho; 
- Modelagem de TWR, APP, ACC e suas aerovias; e

- Movimentação na TMA e em seus aeroportos, incluindo alocação de gates e gerenciamento de operações de taxiamento.

Com base nestas ferramentas, foram elaborados cenários para os estudos de caso apresentados neste trabalho de pesquisa. No contexto do tráfego aéreo, cada aeronave deve respeitar uma distância de separação mínima a fim de evitar risco de colisão com as demais aeronaves. O distanciamento mínimo entre as aeronaves deve ser aplicado pelos controladores de tráfego aéreo e é tecnicamente chamado de separação. Para aplicar a separação, um volume virtual, chamado de volume de proteção, é concebido ao redor de cada aeronave, conforme ilustrado na Figura 47.

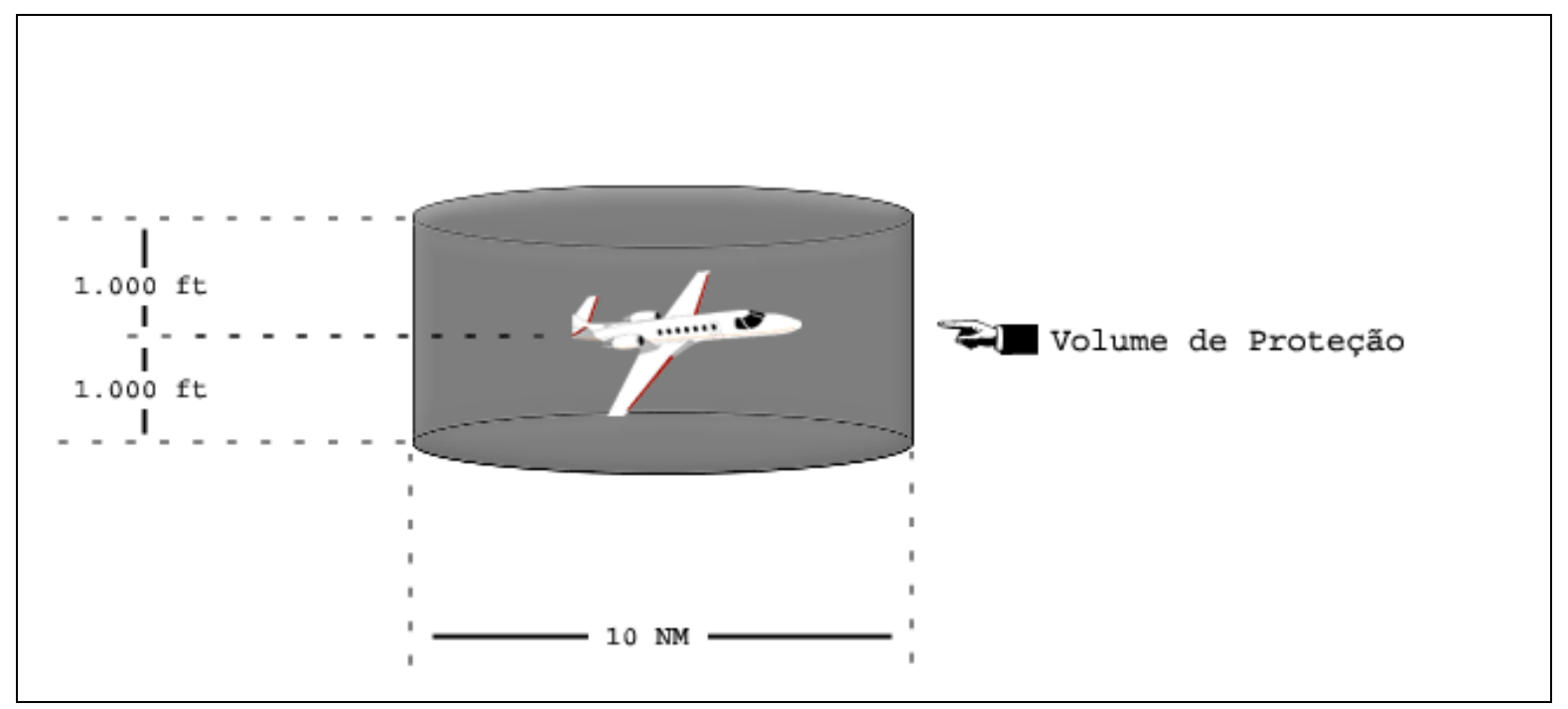

Figura 47 - Volume de proteção de uma aeronave.

As distâncias de separação são indicadas pelos órgãos regulamentadores do controle de tráfego aéreo, como a ICAO (International Civil Aviation Organization), e ajustadas para o ambiente específico de cada região. No caso da separação vertical mínima (RVSM - Reduced Vertical Separation Minimum), a ICAO recomenda que seja adotado 1.000 pés (ICAO, 2004 e ICAO, 1996). Já no caso da separação longitudinal (frente e parte de trás da aeronave) e lateral (lados direito e esquerdo da aeronave), estas são ajustadas de acordo com as particularidades de cada região. No espaço aéreo brasileiro, os parâmetros de separação podem ser encontrados no documento (IMA 100-12, 1999). De forma geral, as distâncias estabelecidas para o espaço aéreo estudado, que estão sob cobertura radar, variam de 5 a 10 milhas náuticas (IMA 100-12, 1999). 
Um conflito ocorre quando uma aeronave penetra o volume de proteção de uma segunda aeronave. Neste instante, o controlador de tráfego aéreo, em coordenação com os pilotos das aeronaves, tem que agir rapidamente a fim de evitar uma possível colisão.

O software utilizado para as simulações computacionais presentes neste trabalho de pesquisa, o RAMS Plus, implementa o conceito de volume de proteção. No RAMS Plus, quando ocorre um conflito, este é contabilizado e o software pode ou não iniciar a função de resolução de conflito nele presente (função que pode ou não ser habilitada pelo usuário) e que será responsável por solucionar o conflito detectado. Em todas as simulações foram utilizadas as distâncias de separação vertical de 1.000 pés e de 10 milhas náuticas para as separações longitudinal e lateral.

Uma importante análise para o estudo da carga de trabalho dos controladores de tráfego aéreo é o cálculo da complexidade dos setores de um espaço aéreo. Este cálculo é baseado na função complexidade desenvolvida pela NASA e que tem vários fatores como entradas, chamados de fatores de complexidade. Este fatores são combinados em uma fórmula que expressa a complexidade de um setor. A seguir é apresentada uma breve explicação a respeito dos fatores de complexidade que compõem a função de complexidade descrita pela NASA. Mais detalhes estão disponíveis em (RAMS, 2005) e (NASA, 1996). Os fatores de complexidades são os seguintes:

a) Número de Aeronaves (ACT - Aircraft Count): representa o número de aeronaves contidas em um instante de tempo em um dado setor;

b) Densidade de Aeronaves (DNS - Aircraft Density): a densidade de aeronaves é o número de aeronaves em um instante de tempo (ACT), em um dado setor, dividido pelo volume do setor;

c) Estrutura do Espaço (STR - Airspace Structure): este fator mede a conformidade do fluxo de aeronaves com a geometria do setor. Entende-se como conformidade a adequação das aerovias e o sentido das pistas nos aeroportos com a geometria e disposição das bordas dos setores;

d) Subida ou Descida ( $\mathrm{CoD}$ - Climbing or Descending): representa o número de aeronaves que estão em operação de subida ou em operação de descida, em um dado instante de tempo, no setor;

e) Ponto de Aproximação (CPA - Closest Points Approach): este fator de complexidade representa a evolução da separação das aeronaves, umas das outras, a 
partir de uma separação inicial em um dado instante de tempo, em um dado setor. Com o passar do tempo, caso a separação entre as aeronaves diminua em relação à separação inicial, os controladores terão que ter uma maior atenção no controle do tráfego a fim de evitar futuros conflitos;

f) Aeronaves Próximas a Borda de Setores (PRX - Aircraft Proximity to Sector Boundary): representa o número de aeronaves que estão próximos das bordas de um setor em um dado instante de tempo;

g) Variação nas Direções dos Vôos (VDF - Variance in Directions of Flight): representa a variação da direção de todas as aeronaves, em um setor, em um dado instante de tempo;

h) Ângulo de Convergência (ANG - Convergence Angle): este fator da complexidade é uma medida da severidade de cada situação de conflito, baseada na geometria do conflito;

i) Conflitos Próximos a Borda de Setores (PRC - Conflict Near Sector Boundary): representa o número de conflitos preditos que podem ocorrer próximos às bordas de um determinado setor;

j) Aeronaves Próximas ao Conflito (NBR - Aircraft Neighboring Conflict): representa o número de aeronaves que estão próximas às aéreas de conflito; e

k) Conhecimento da Evolução do Plano de Vôo (INT - Intent Knowledge): representa o nível de conhecimento por parte dos controladores sobre a evolução do plano de vôo das aeronaves. Este fator é relevante em situações em que não existe um plano de vôo para as aeronaves.

Estes fatores de complexidades são combinados, segundo (NASA, 1996), e representados pela seguinte fórmula:

Fator de Complexidade do Setor $=$

$\begin{array}{llll}0,0172 & \mathrm{x} & \operatorname{MAX}[\operatorname{ACT}(\mathrm{t}), \ldots, \operatorname{ACT}(\mathrm{t}+\Delta \mathrm{t})] & + \\ 0,3280 & \mathrm{x} & \operatorname{MAX}[\operatorname{DNS}(\mathrm{t}), \ldots, \operatorname{DNS}(\mathrm{t}+\Delta \mathrm{t})] & + \\ 0,0676 & \mathrm{x} & \operatorname{MAX}[\operatorname{STR}(\mathrm{t}), \ldots, \operatorname{STR}(\mathrm{t}+\Delta \mathrm{t})] & + \\ 0,1134 & \mathrm{x} & \operatorname{SUM}[\operatorname{CoD}(\mathrm{t}), \ldots, \operatorname{CoD}(\mathrm{t}+\Delta \mathrm{t})] & + \\ 0,0498 & \mathrm{x} & \operatorname{SUM}[\operatorname{CPA}(\mathrm{t}), \ldots, \operatorname{CPA}(\mathrm{t}+\Delta \mathrm{t})] & + \\ 0,2000 & \mathrm{x} & \operatorname{SUM}[\operatorname{PRX}(\mathrm{t}), \ldots, \operatorname{PRX}(\mathrm{t}+\Delta \mathrm{t})] & +\end{array}$




$\begin{array}{llll}0,0709 & x & \operatorname{MAX}[\operatorname{VDF}(\mathrm{t}), \ldots, \operatorname{VDF}(\mathrm{t}+\Delta \mathrm{t})] & + \\ 0,1070 & \mathrm{x} & \operatorname{SUM}[\operatorname{ANG}(\mathrm{t}), \ldots, \operatorname{ANG}(\mathrm{t}+\Delta \mathrm{t})] & + \\ 0,0754 & \mathrm{x} & \operatorname{SUM}[\operatorname{PRC}(\mathrm{t}), \ldots, \operatorname{PRC}(\mathrm{t}+\Delta \mathrm{t})] & + \\ 0,0426 & \mathrm{x} & \operatorname{SUM}[\operatorname{NBR}(\mathrm{t}), \ldots, \operatorname{NBR}(\mathrm{t}+\Delta \mathrm{t})] & + \\ 0,2564 & \mathrm{x} & \operatorname{MAX}[\operatorname{INT}(\mathrm{t}), \ldots, \operatorname{INT}(\mathrm{t}+\Delta \mathrm{t})] & \end{array}$

O resultado da função complexidade expressa a soma ponderada das contribuições individuais de cada fator de complexidade. Cada fator de complexidade contribui para o cálculo da função complexidade por meio de uma função máximo (MAX) ou função soma (SUM). Para os fatores que modelam as características do cenário de um tráfego aéreo, tendo uma continuidade com o passar do tempo (por exemplo, o fator ACT, que representa o número de aeronaves no espaço aéreo considerado), é utilizado o pior caso, com o uso da função MAX, pois esses fatores têm um impacto durante todo o tráfego de aeronaves no espaço aéreo. Já para os fatores que pontualmente contribuíram para a complexidade do espaço aéreo (por exemplo, o fator PRX, que representa a proximidade de aeronaves junto à borda de um setor) é utilizada a função SUM para compor a função complexidade.

O RAMS Plus permite utilizar este conceito, implementando a fórmula da função complexidade descrita anteriormente. As análises efetuadas com base nos resultados fornecidos pelas simulações computacionais realizadas para este trabalho exploraram esta função.

\subsection{O Espaço Aéreo Escolhido}

O espaço aéreo escolhido para o estudo de caso, que compõe o cenário de simulação deste trabalho de pesquisa, foi a TMA-SP, controlada pelo Controle de Aproximação de São Paulo (APP-SP), que é formado por seis setores (numerados de 1 a 6), conforme mostra a Figura 48. Dois destes setores (os setores 4 e 5) englobam dois dos aeroportos de maior movimentação no Brasil, respectivamente, Aeroporto de Guarulhos - Aeroporto Internacional de São Paulo Guarulhos (SBGR), e o Aeroporto de Congonhas - Aeroporto Internacional de São Paulo Congonhas (SBSP) (HUPALO, 2003).

Cada um destes setores representados na Figura 48 e também na Figura 49 tem, como responsável pelo controle do seu tráfego aéreo, um controlador e um assistente. O setor 6 é 
chamado de "Tubulão", sendo dedicado exclusivamente para o tráfego aéreo da ponte aérea Rio-São Paulo.

A Figura 49 representa mais detalhadamente a TMA-SP com as rotas de chegada e saída da aeronaves, seus pontos fixos, suas STAR (Standard Arrival Routes), aeroportos e borda de divisão dos setores da TMA-SP. Essa figura foi fornecida pelo Centro de Gerenciamento de Navegação Aérea - CGNA. Mais detalhes sobre estas rotas são apresentados no Capítulo 5.

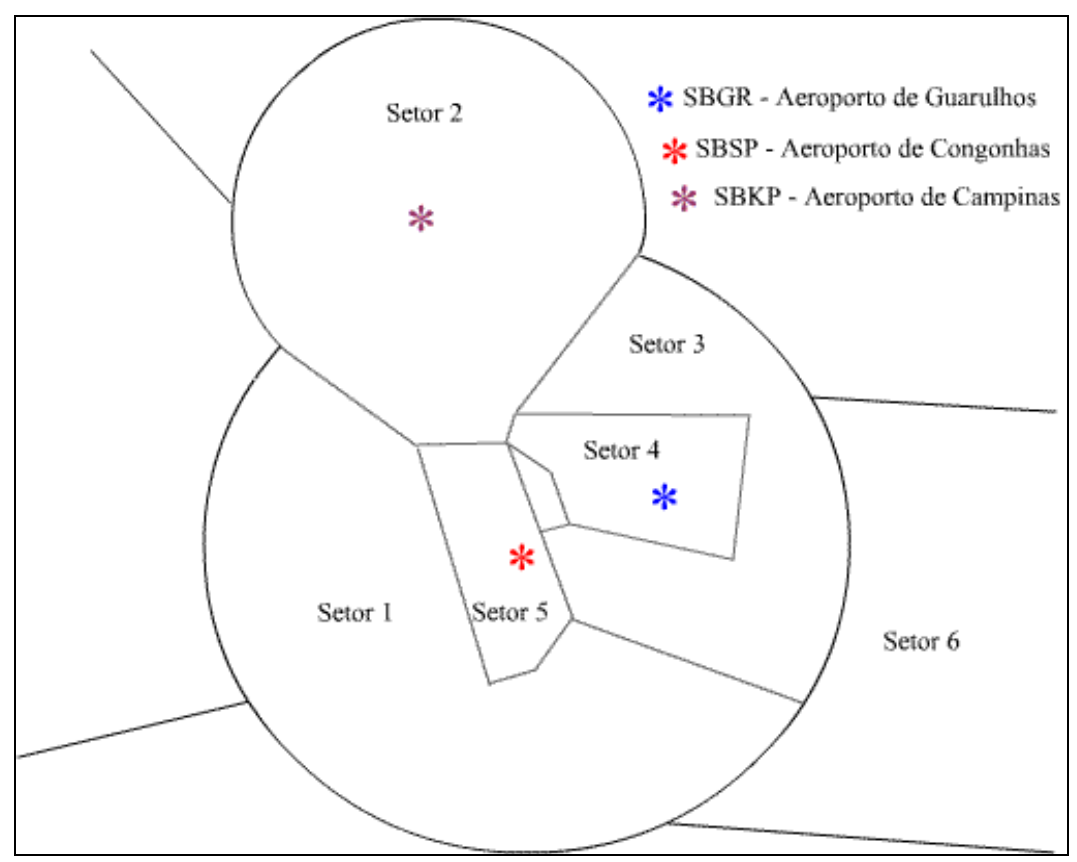

Figura 48 - TMA-SP com seus setores (NCAG 2, 2005). 


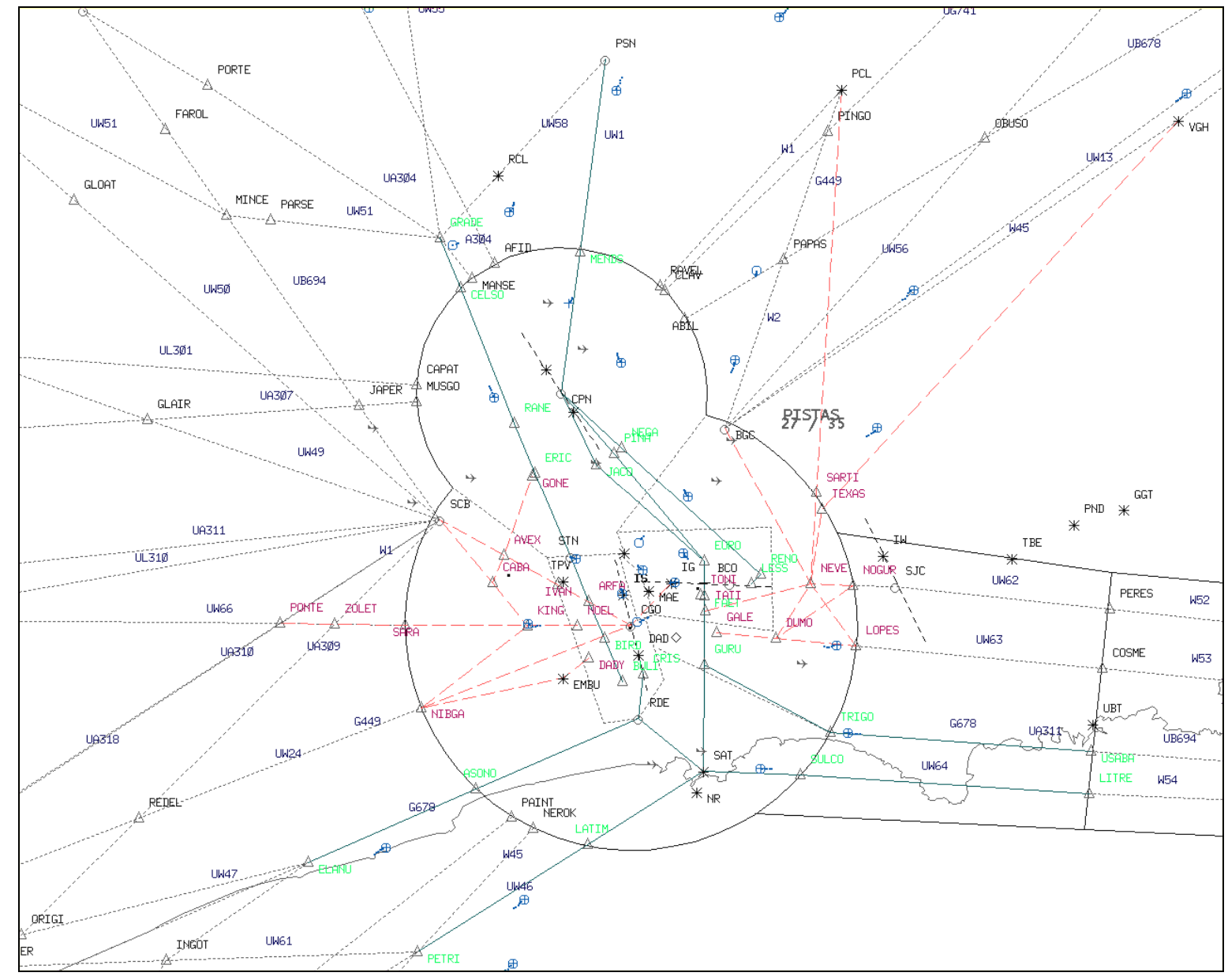

Figura 49 - TMA-SP detalhada (CGNA, 2006).

A capacidade suportada por setor da TMA-SP é mostrada na Tabela 2. Segundo (CGNA, 2006), entende-se por capacidade de um órgão do ATC ou de um setor " $a$ medida de habilidade do órgão ATC ou de suas posições operacionais em prover serviço, em condições normais, para as aeronaves. Essa capacidade é expressa como o número de aeronaves entrando em determinada porção de espaço aéreo, em um dado período de tempo, levando em conta as condições meteorológicas, a configuração do órgão ATC, o pessoal e os equipamentos disponíveis, bem como quaisquer outros fatores que possam afetar a carga de trabalho do controlador de tráfego aéreo responsável pelo espaço aéreo. Também poderá ser expressa como o número máximo de aeronaves simultâneas sob jurisdição de uma posição de controle de um órgão ATC, suportado pela infra-estrutura aeronáutica instalada".

Devido a exclusividade de tráfego, as condições de trabalho e infra-estrutura dedicada, o "Tubulão" é o setor que tem a maior capacidade na TMA-SP. 
Tabela 2 - Capacidade da TMA-SP em movimento de aeronaves por hora.

\begin{tabular}{|c|c|}
\hline Setor da TMA-SP & Número de Movimentos por Hora \\
\hline Setor 1 & 55 \\
\hline Setor 2 & 50 \\
\hline Setor 3 & 40 \\
\hline Setor 4 & 46 \\
\hline Setor 5 & 43 \\
\hline Setor 6 & 79 \\
\hline Total & $\mathbf{3 1 3}$ \\
\hline
\end{tabular}

Nos casos de vôos visuais VFR sobre a TMA São Paulo, foi alocado um volume de espaço aéreo com limite verticais com altitudes variando entre 3500 e 5000 pés, referentes respectivamente aos níveis de vôo (FL) 035 e 050, e limites horizontais variando de 2 a 3 NM, de forma a não interferir no controle e no tráfego dos vôos IFR dos aeródromos de Guarulhos, Congonhas e Viracopos. Para esses casos, foram também construídos corredores com limites de altura e percurso bem definidos cujo controle de tráfego fica sobre a responsabilidade de um setor especifico, o setor 7 (não considerado neste trabalho, devido ao controle deste setor estar dedicado a um controlador de tráfego aéreo específico, não influenciando o controle dos demais setores do espaço aéreo da TMA-SP). Estes corredores estão definidos na Figura 50 (AIC 12/06, 2006) e na Figura 51. 


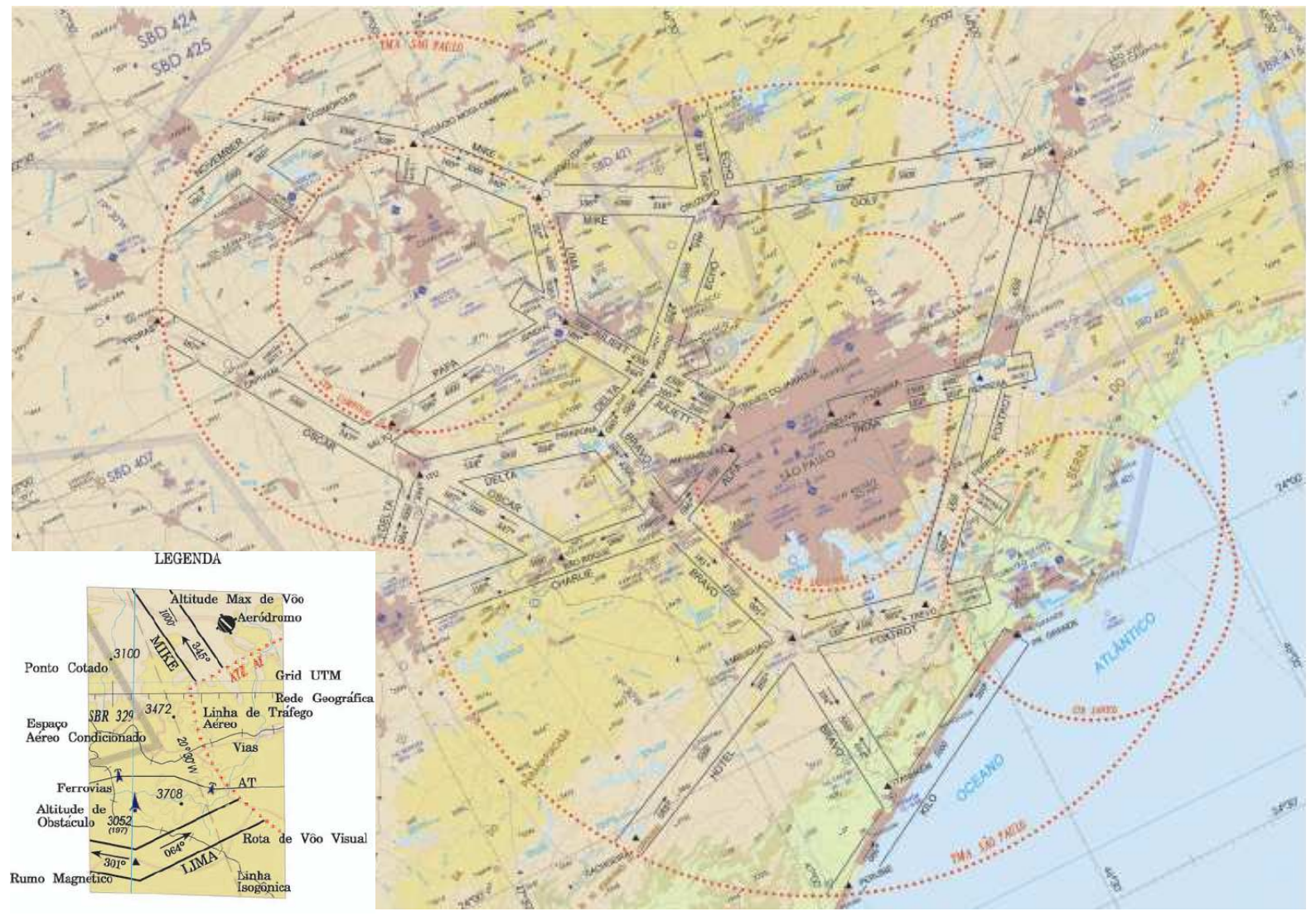

Figura 50 - Rotas especiais para vôo VFR sobre a TMA-SP (AIC 12/06, 2006).

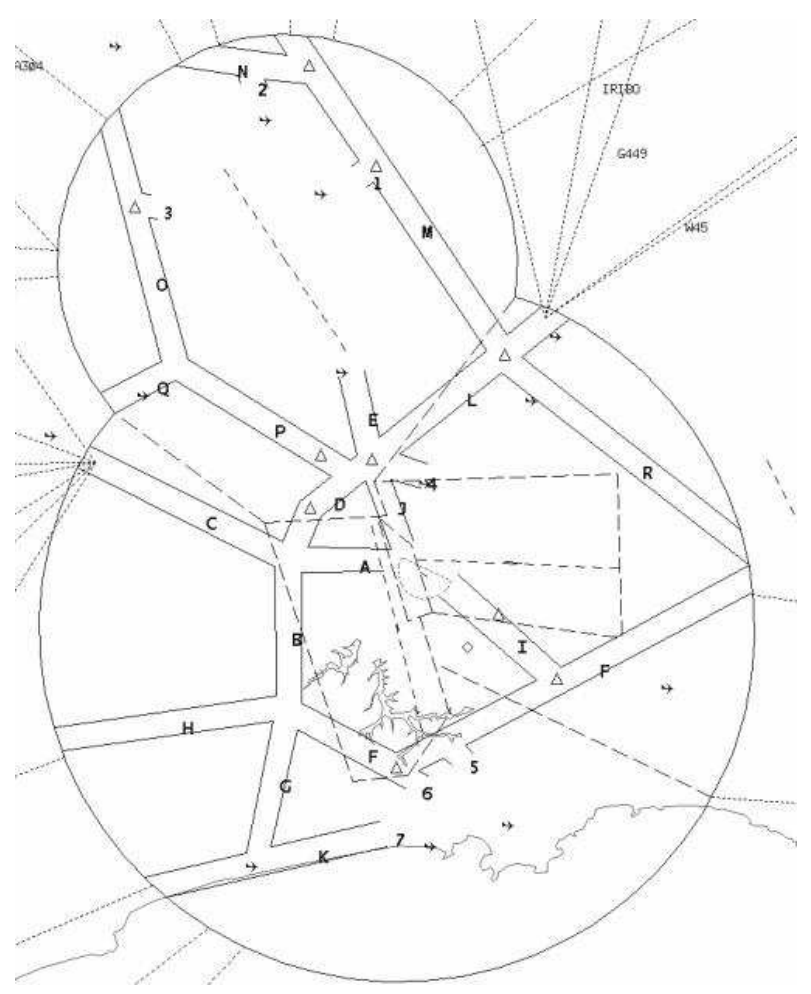

Figura 51- Rotas especiais para vôo VFR sobre a TMA-SP (DECEA, 2007). 
Com o estabelecimento das Rotas Especiais de Aviões sobre a TMA-SP, é possível isolar os vôos VFR e os IFR, separando a carga de trabalho dos controladores envolvidos com estes vôos. Em outras palavras, a carga de trabalho dos controladores responsáveis por controlar e prestar serviço aos vôos IFR não interfere na carga de trabalho dos controladores que atuam sobre os vôos VFR, e vice-versa.

\subsection{Cenários Propostos}

Nos estudos de caso elaborados para este trabalho de investigação científica foi escolhido o espaço aéreo controlado pelo APP-SP. De posse dos dados reais do tráfego aéreo na TMA-SP, fornecidos por este órgão, foram construídos dois cenários utilizados nas simulações computacionais.

O primeiro consiste no tráfego da TMA-SP em um dia com grande volume de aeronaves neste espaço. Já o segundo utiliza um dia com volume de aeronaves típico na TMA-SP e extrapola este volume para valores esperados para o ano de 2015. Submetendo estes dois cenários de tráfego aéreo da TMA-SP, utilizando a configuração atual e aquela baseada na re-setorização dinâmica, foram construídos os estudos de casos descritos a seguir.

Estudo de Caso 1: um motivo proposto para utilizar a RD é devido a uma alta demanda de aeronaves em um espaço aéreo, de forma não balanceada, nos diversos períodos de tempo de um dia, e nos diversos setores do espaço aéreo. O cenário escolhido para este estudo de caso foi um dia de tráfego aéreo com alto volume de aeronaves na TMA-SP, considerando o padrão de tráfego do ano de 2006. Para este caso foram feitas duas simulações, uma com a configuração atualmente existente na TMA-SP, e outra com o mesmo tráfego (com alto volume de aeronaves), mas utilizando a RDL na TMA-SP. Para ambas as simulações foram medidas as cargas de trabalho dos controladores de tráfego aéreo, entre outras informações; e

Estudo de Caso 2: neste outro estudo de caso foi extrapolado o tráfego aéreo atualmente integrante da TMA-SP para o esperado no ano de 2015, segundo previsão determinada pelo Instituto da Aviação Civil - IAC. O motivo da elaboração deste estudo de caso é analisar como se comporta a atual configuração da TMA-SP, considerado o crescimento esperado para 2015. Utilizando as mesmas configurações do espaço aéreo empregadas no Estudo de Caso 1, foram efetuadas simulações para análise da utilização da RDL. Nessas simulações também 
foram estimadas as cargas de trabalho dos controladores de tráfego aéreo, dentre outras informações.

\subsection{Considerações Finais do Capítulo}

Esse capítulo contextualizou a teoria sobre a Re-setorização Dinâmica Limitada (RDL) com a prática. Mostrou também os estudos de caso propostos e o cenário utilizado, no caso, a TMASP, para aplicação das simulações computacionais, utilizando o software de simulação RAMS Plus. A partir da teoria descrita nos capítulo 2 e 3, os resultados e análises dos resultados dos estudos de casos são apresentados no capítulo 5 deste trabalho. 


\title{
5 Modelagem e Análise dos Resultados das Simulações
}

\begin{abstract}
Este capítulo tem como finalidade apresentar os resultados do estudo de caso investigado neste trabalho de pesquisa. Inicialmente é abordada a modelagem do cenário de setores a ser utilizado e a forma do tratamento dos dados utilizados nas simulações computacionais. Em seguida, são apresentados os resultados e as análises dos estudos de caso simulados.
\end{abstract}

O cenário escolhido para realização das simulações neste trabalho corresponde ao espaço aéreo da TMA-SP, composto de seus seis setores e três aeroportos principais: SBGR, Aeroporto Internacional de São Paulo - Guarulhos; SBSP, Aeroporto Internacional de São Paulo - Congonhas; e SBKP, Aeroporto Internacional de Viracopos, em Campinas. Com base nas visitas feitas ao APP-SP, nas diversas entrevistas realizadas com os controladores de tráfego aéreo e nas pesquisas realizadas, modelou-se o espaço aéreo da TMA-SP na ferramenta de simulação RAMS Plus, aplicando-o nos dois estudos de caso propostos no Capítulo 4. A descrição deste modelo, bem como a análise e os resultados dos estudos de casos são apresentados a seguir.

\subsection{Modelagem do Cenário e Tratamento dos Dados Utilizados nas Simulações}

O ponto inicial na modelagem do cenário para os estudos de caso, referente ao espaço aéreo da TMA-SP, foi a análise das Cartas Aéreas ${ }^{5}$ e da AIP Brasil ${ }^{6}$. Definiram-se, primeiramente, a geometria dos setores, as coordenadas dos aeroportos SBGR, SBKP e SBSP, e os pontos fixos do espaço aéreo desta TMA (DECEA, 2004; AIP BRASIL, 2004). Definidos esses pontos, foi

\footnotetext{
${ }^{5}$ Cartas de Áreas, além de conterem informações que facilitam as transições entre o vôo em rota e a aproximação para um aeródromo, ilustram a configuração dos setores pertencentes ao espaço aéreo de forma detalhada (SALLES, 2006).

${ }^{6}$ AIP Brasil - Publicação de Informações Aeronáuticas do Brasil, sendo um documento que contém informações aeronáuticas publicadas no Brasil, de caráter essenciais à navegação aérea (SALLES, 2006).
} 
possível construir a TMA-SP e seus setores adjacentes no software de simulação RAMS Plus, conforme ilustra a Figura 52.

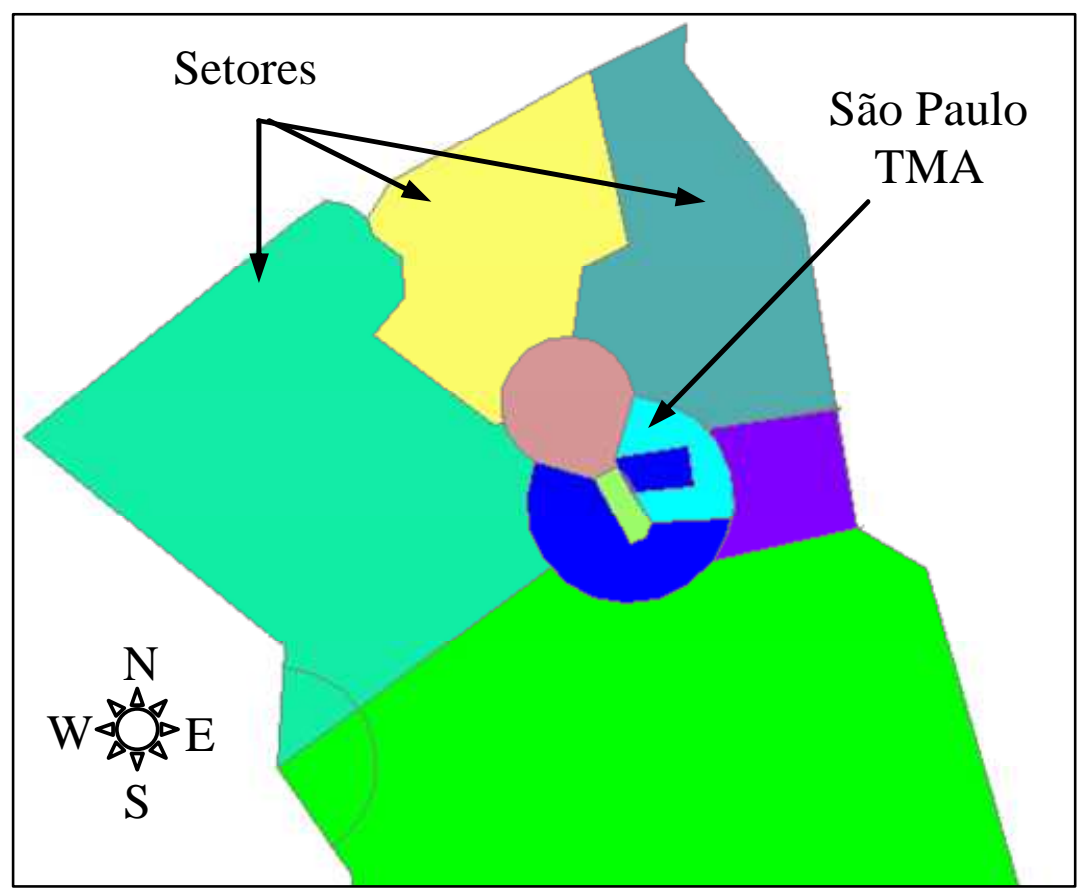

Figura 52 - TMA-SP e seus setores adjacentes.

Tendo os setores e os aeroportos construídos, além dos pontos fixos definidos, o próximo passo é traçar as rotas SIDs (Saída Padrão por Instrumento) e STARs (Chegada Padrão por Instrumentos), dos pontos fixos até seus respectivos aeroportos. O traçado destas rotas foi baseado nas Cartas de Área sobre a TMA-SP (vide Figura 53).

Cada SID tem início em seu respectivo aeroporto da TMA-SP. Em contrapartida, cada aeroporto da TMA-SP é o final de uma STAR. Os pontos pretos representam os fixos finais de cada SID ou iniciais de cada STAR. Existem outros pontos fixos que determinam o caminho intermediário de cada SID/STAR até o aeroporto, representados na Figura 53.

Após a construção de cada cenário para a simulação, foi necessário fazer um tratamento nos dados a serem utilizados na simulação. Estes dados são reais e foram fornecidos pelo controle de tráfego aéreo de São Paulo (APP-SP). Esses dados refletem dois dias de operação do controle de tráfego aéreo: um dia com grande volume de aeronaves e um dia com tráfego aéreo típico na TMA-SP, ambos referentes ao ano de 2006. 


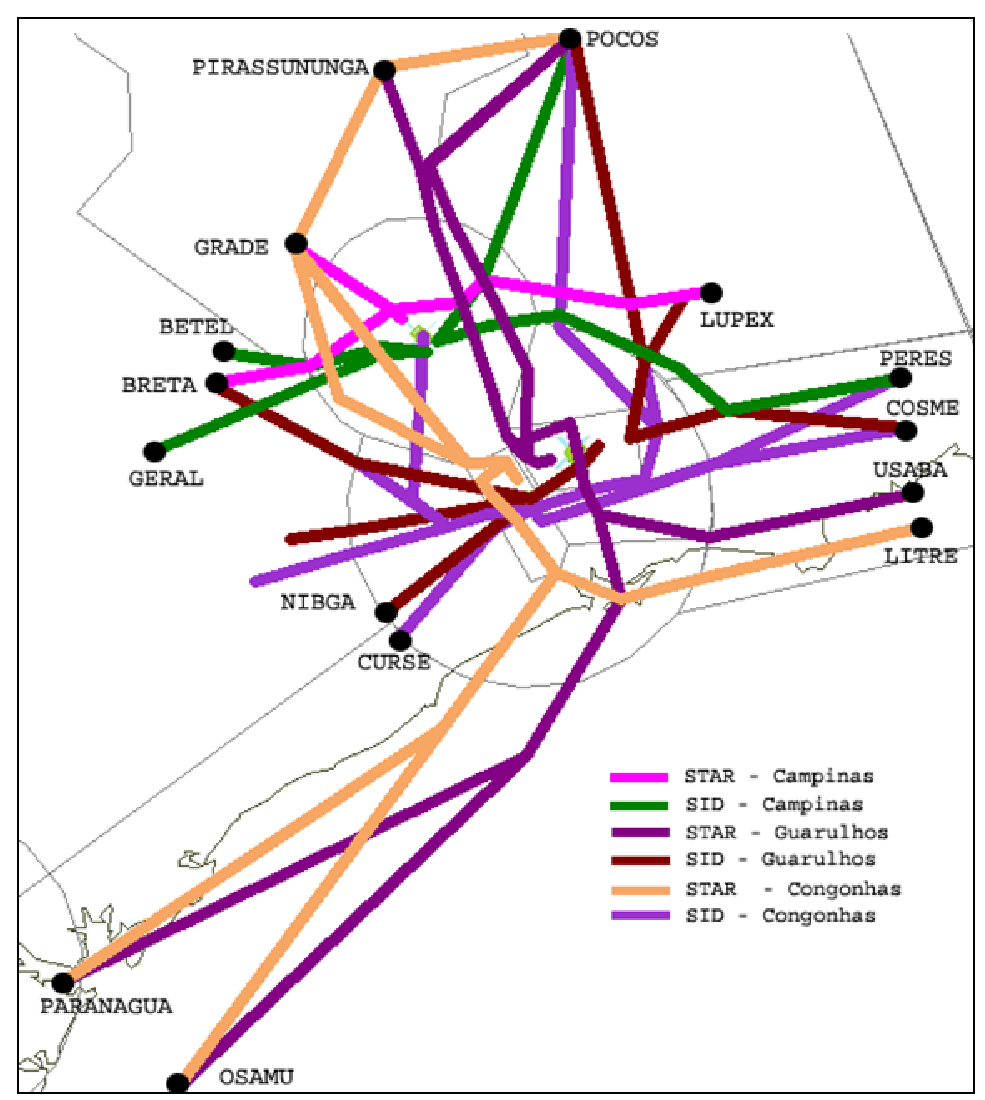

Figura 53 - Rotas SIDs e STARs da TMA-SP.

Os dias repassados foram: 30/08/2006 (dia com alto tráfego de aeronaves), com 806 vôos de partida e 790 vôos de chegada, totalizando 1596 vôos; e 04/09/2006 (dia de tráfego de aeronaves típico), com 709 vôos de partida e 695 vôos de chegada, totalizando 1404 vôos. Nestes dados estão contidos vôos IFR, vôos VFR e tráfego de helicópteros, conforme ilustram a Figura 54 e a Figura 55, contendo o número de movimentos (pouso e decolagem), além da porcentagem destes números por aeroporto da TMA-SP. Informações detalhadas desses vôos podem ser encontradas no Anexo I deste trabalho.

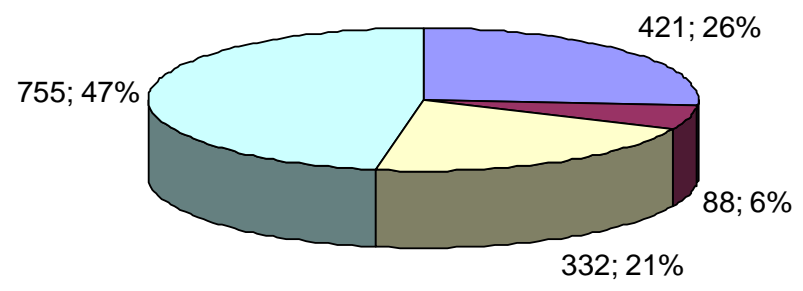

$\square$ SBGR $\square$ SBKP $\square$ SBMT $\square$ SBSP

Figura 54 - Número de aeronaves e porcentagem de aeronaves na TMA-SP, por aeroporto, em 30/08/2006. 


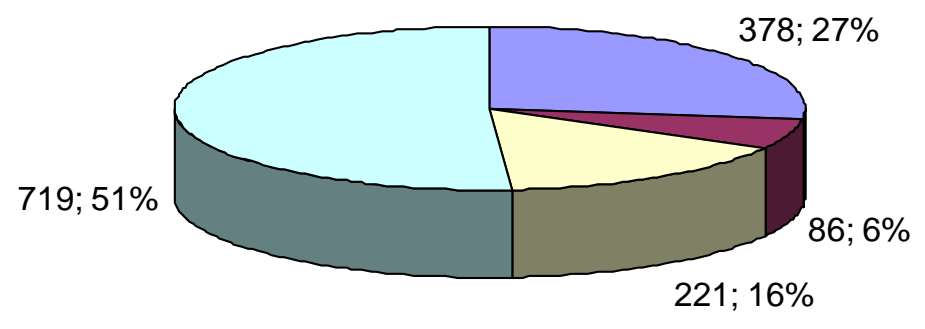

\section{SBGR $\square$ SBKP $\square$ SBMT $\square$ SBSP}

Figura 55 - Número de aeronaves e porcentagem de aeronaves na TMA-SP, por aeroporto, em 04/09/2006.

Um dos focos deste trabalho é estudar de forma comparativa a carga de trabalho dos controladores de tráfego aéreo, considerando diversos cenários de setorização do espaço aéreo. Para isto é preciso entender como o tráfego de aeronaves influencia a carga de trabalho desses controladores. Os serviços prestados pelo controle de tráfego aéreo para os vôos VFR e de helicópteros é só de monitoração, só existindo uma intervenção do controlador em situações de risco. Outro ponto em comum nestes dois tráfegos na TMA-SP é que eles não influenciam no controle dos vôos IFR, pois existem controladores próprios para cada um desses tráfegos (maiores detalhes a respeito podem ser encontrados no item 4.4). Portanto, foi feito um filtro sobre os dados originais fornecidos, retirando-se todo o tráfego de vôos VFR e de helicópteros, isolando-se somente os vôos IFR para efeitos de simulação computacional.

Outro ponto considerado no tratamento dos dados foi o tráfego sobre o Aeroporto Campo de Marte. No Aeroporto Campo de Marte, o volume de vôos IFR sobre este aeródromo, presentes nos dados colhidos após a retirada dos vôos VFR e dos helicópteros, representaram menos de $1 \%$ do volume total sobre a TMA-SP. Logo, os vôos de partida e chegada no Aeroporto Campo de Marte não foram considerados nas simulações efetuadas neste trabalho.

Após a aplicação desses filtros, o número de vôos efetivamente considerado para a simulação de cada um dos dias analisados são os seguintes: 1087 vôos em 30/08/2006 (de um total de 1596), e 1052 vôos em 04/09/2006 (de um total de 1404), conforme ilustram a Figura 56 e a Figura 57. 


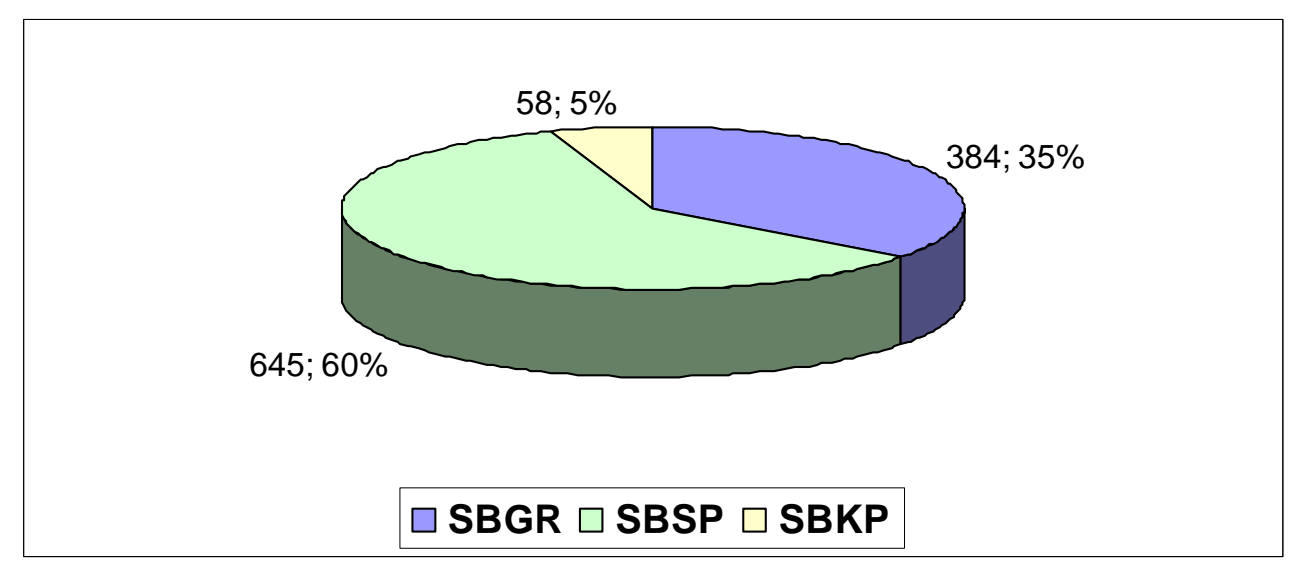

Figura 56 - Número efetivo de aeronaves e porcentagem de aeronaves na TMA-SP, por aeroporto, em 30/08/2006.

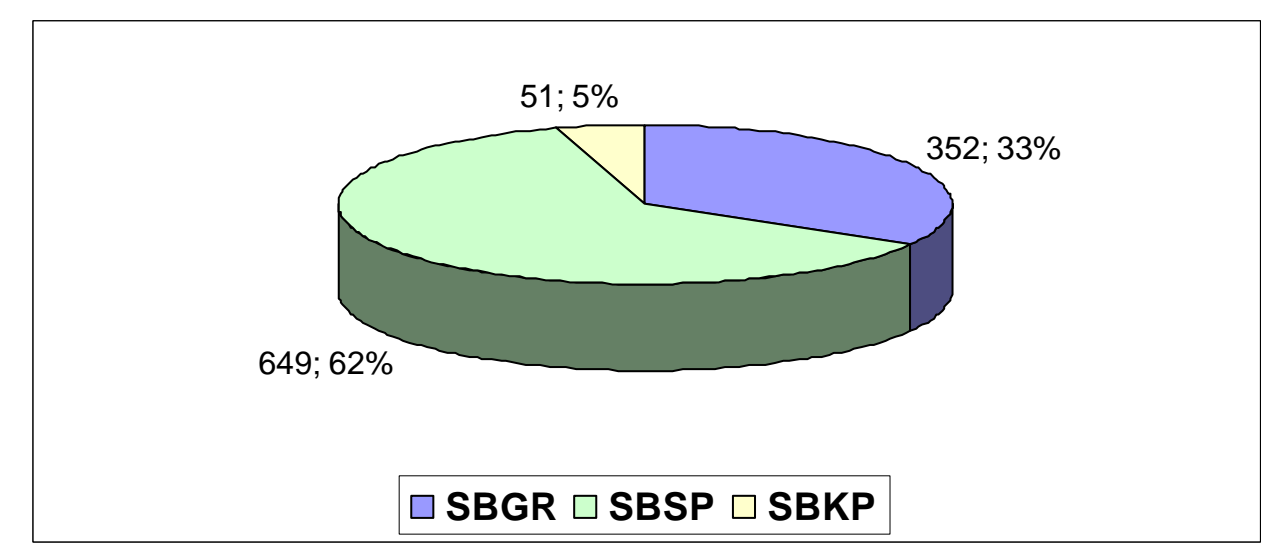

Figura 57 - Número efetivo de aeronaves e porcentagem de aeronaves na TMA-SP, por aeroporto, em 04/09/2006.

Algumas companhias têm várias versões para uma mesma família de aeronave. Assim, o Boeing 777, por exemplo, tem duas versões: o B777-200 e o B777-300. Nos dados fornecidos, estas versões apresentam-se de forma abreviada (por exemplo, o Boeing 737-600 aparece descrito como Boeing 736). Para a normalização dos modelos das aeronaves foi utilizada a Tabela 3, considerando-se nas simulações apenas as famílias das aeronaves sem suas particulares versões. Ainda para exemplificar, nas simulações é utilizado o Boeing B777 tanto para os vôos que utilizaram o Boeing B777-200 como para os vôos que utilizam Boeing B777-300. 
Tabela 3 - Famílias e versões de aeronaves comerciais.

\begin{tabular}{|c|c|c|}
\hline Família & Abreviação & Modelo \\
\hline Boeing 727 & B722 & B727-200 \\
\hline \multirow{6}{*}{ Boeing 737} & B732 & B737-200 \\
\hline & B735 & B737-500 \\
\hline & B736 & B737-600 \\
\hline & B737 & B737-700 \\
\hline & B738 & B737-800 \\
\hline & B739 & B737-900 \\
\hline Boeing 747 & B744 & B747-400 \\
\hline \multirow{2}{*}{ Boeing 767} & B762 & B767-200 \\
\hline & B763 & B767-300 \\
\hline \multirow{2}{*}{ Boeing 777} & B772 & B777-200 \\
\hline & B773 & B777-300 \\
\hline \multirow{3}{*}{ AirBus 320} & A318 & A318 \\
\hline & A319 & A319 \\
\hline & A321 & A321 \\
\hline \multirow{2}{*}{ AirBus 330} & A332 & A330-200 \\
\hline & A333 & A330-300 \\
\hline \multirow{4}{*}{ AirBus 340} & A342 & A $340-200$ \\
\hline & A343 & A $340-300$ \\
\hline & A345 & A $340-500$ \\
\hline & A346 & A340-600 \\
\hline
\end{tabular}

Um outro aspecto a ser considerado é que nos dados fornecidos aparecem, para cada vôo, apenas os aeroportos de origem e destino, o nome do vôo com seus respectivos horários, o tipo de aeronave e a indicação se o vôo e o aeródromo operavam de forma visual (VFR) ou por instrumento (IFR). Portanto, um segundo passo após realizar os filtros e as normalizações dos dados foi alocar os vôos em sua respectiva SID e STAR ao redor da TMA-SP (informação esta não disponível explicitamente nos dados disponíveis). Para tanto, a TMA-SP foi dividida em 4 quadrantes, Q1, Q2, Q3, e Q4, detalhados na Figura 58 (separados por linhas pretas). 


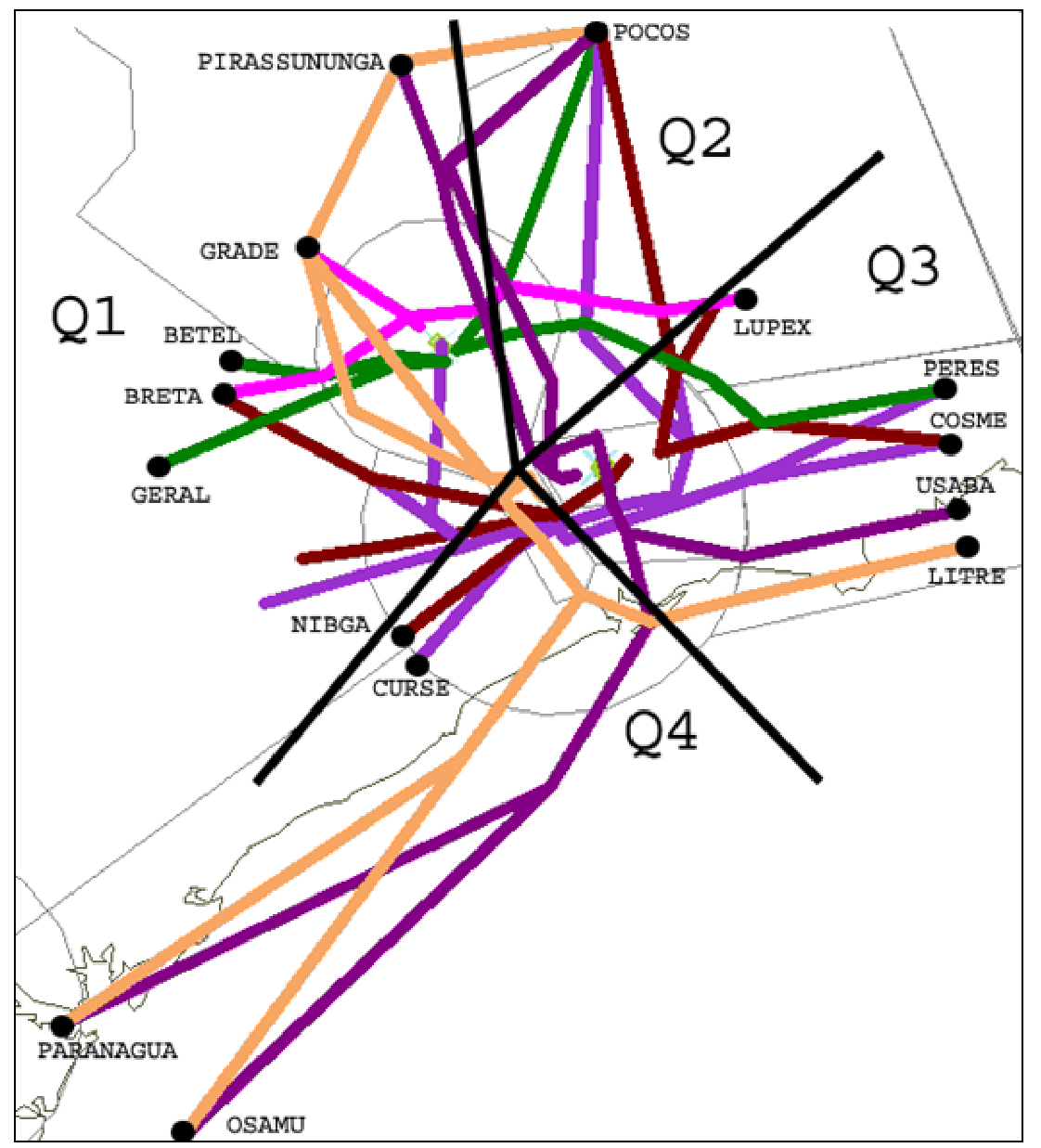

Figura 58 - Quadrantes com suas respectivas SIDs e STARs.

Nas informações fornecidas, os vôos não estavam explicitamente alocados a uma rota SID ou STAR. Para efetuar essa alocação, foi necessário realizar entrevistas com controladores de tráfego aéreo e pilotos de aeronaves, que auxiliaram na alocação dos vôos em cada uma das SIDs ou STARs.

Assim, os vôos com destino ou procedência da região norte e centro-oeste do país, dos EUA, do norte da América do Sul, da América Central e do interior de São Paulo, são alocados no quadrante Q1. Os vôos com destino ou procedência da Europa, da África, da Ásia, da região Nordeste e de Belo Horizonte são alocados no quadrante Q2. O quadrante Q3 fica restrito a ponte aérea Rio-São Paulo. Já os vôos com destino e procedência da região sul do país e do sul da América do Sul são alocados no quadrante Q4. Uma exceção nessa divisão foram os vôos que decolam de Congonhas e que só saem pelo quadrante Q1 ou Q4, independentemente 
do destino. Ainda no caso de Congonhas, os vôos com destino situados nas regiões sul do país saem pelo quadrante Q4, enquanto que o restante dos vôos sai pelo quadrante Q1.

A Figura 59 ilustra uma síntese dos procedimentos descritos na modelagem e tratamento dos dados apresentados anteriormente.

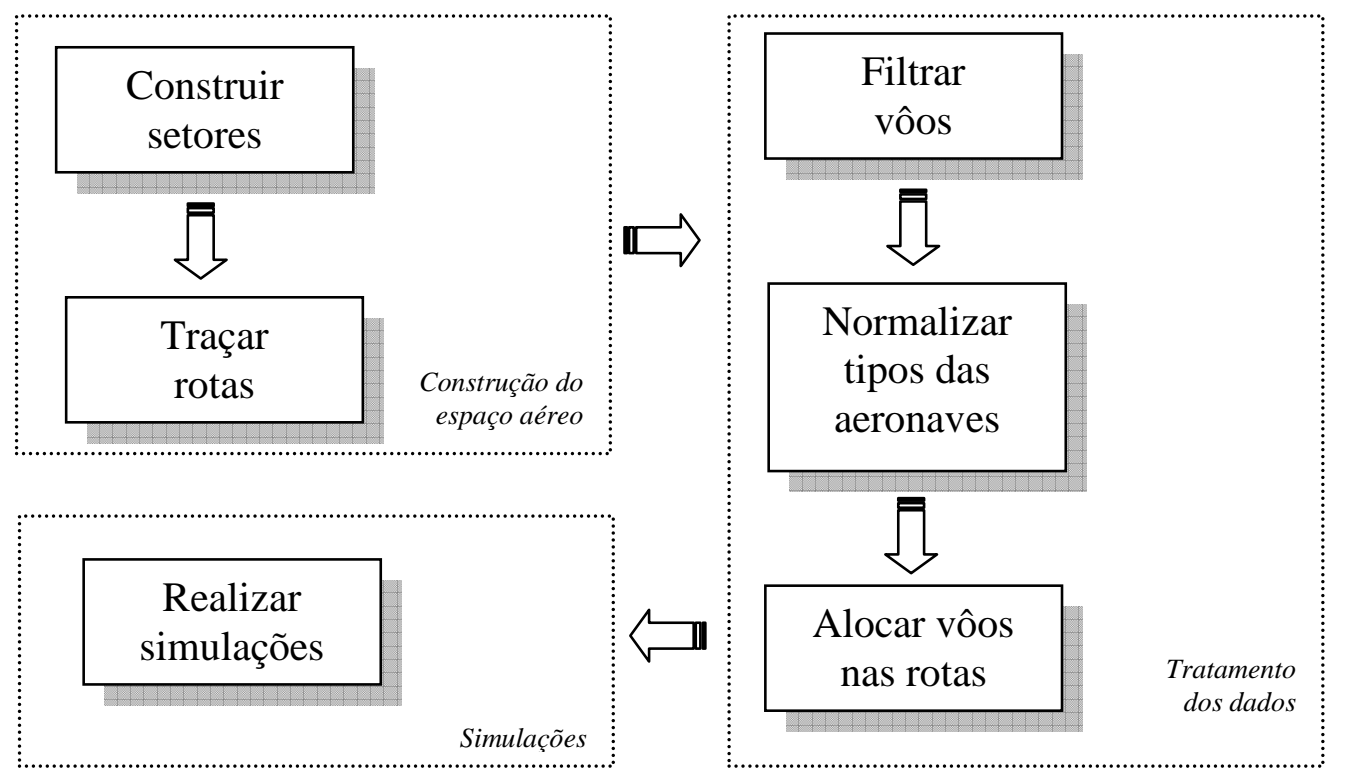

Figura 59 - Fluxo da modelagem do cenário de simulação e de tratamento dos dados.

Os procedimentos de pré-simulação são agrupados em dois grandes grupos a saber: Construção do espaço aéreo e Tratamento dos dados. A Construção do espaço aéreo é composta por duas tarefas: a primeira, Construir setores, baseada nas definições físicas e geográficas de tamanho, posição, altitude, longitude e latitude dos setores; a segunda, denominada Traçar rotas, faz o traçado de rotas a partir dos seus pontos fixos. Já o procedimento de Tratamento dos dados é divido em três tarefas: a primeira, Filtrar vôos, extrai somente os vôos pertinente à investigação, no caso os vôos IFR; a segunda, Normalizar tipos das aeronaves, é a atividade realizada mediante o uso da Tabela 3; e a terceira, Alocar vôos nas rotas, efetua a alocação das rotas com base na origem e destino dos vôos. Após realizar estas tarefas, os dados e o cenário estão prontos para serem utilizados nas simulações computacionais, que são descritas a seguir. 


\subsubsection{Definição das Configurações da TMA-SP e das Tarefas dos Controladores de Tráfego Aéreo Utilizadas nas Simulações}

Nas simulações, além da configuração atual da TMA-SP, conforme mostra a Figura 60, com seus 6 setores, foram criadas mais duas configurações de setores, sendo uma para o período de baixa densidade de aeronaves como, por exemplo, durante a madrugada, e outra para o período de alta densidade de aeronaves. Todas estas novas configurações respeitaram os princípios descritos no item 2.4, onde são apresentados os pontos de atenção que devem ser levados em consideração durante o processo de setorização do espaço aéreo.

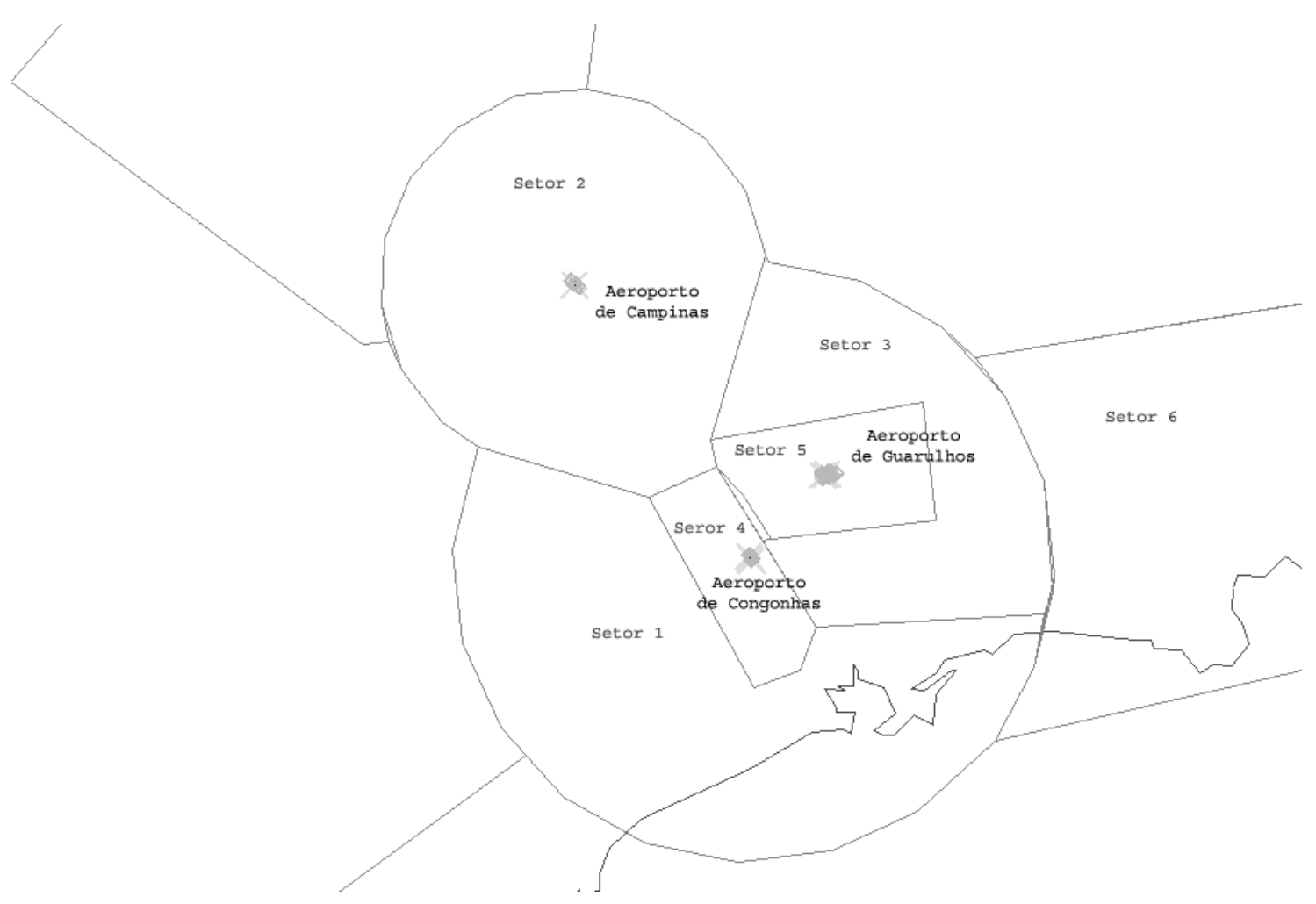

Figura 60 - Configuração atual da TMA-SP.

A Figura 61 representa a configuração da TMA-SP para baixa densidade de aeronaves em seu espaço aéreo. Foi criado para esta configuração o setor 0 , proveniente da união dos setores 1 , 2, e 3. Atualmente, para o período da madrugada, já existe um agrupamento lógico dos setores, em que o mapa dos setores não sofre alterações físicas, ou seja, é delegado para um 
controlador o controle de mais de um setor sem que seja efetuada qualquer mudança na configuração dos setores.

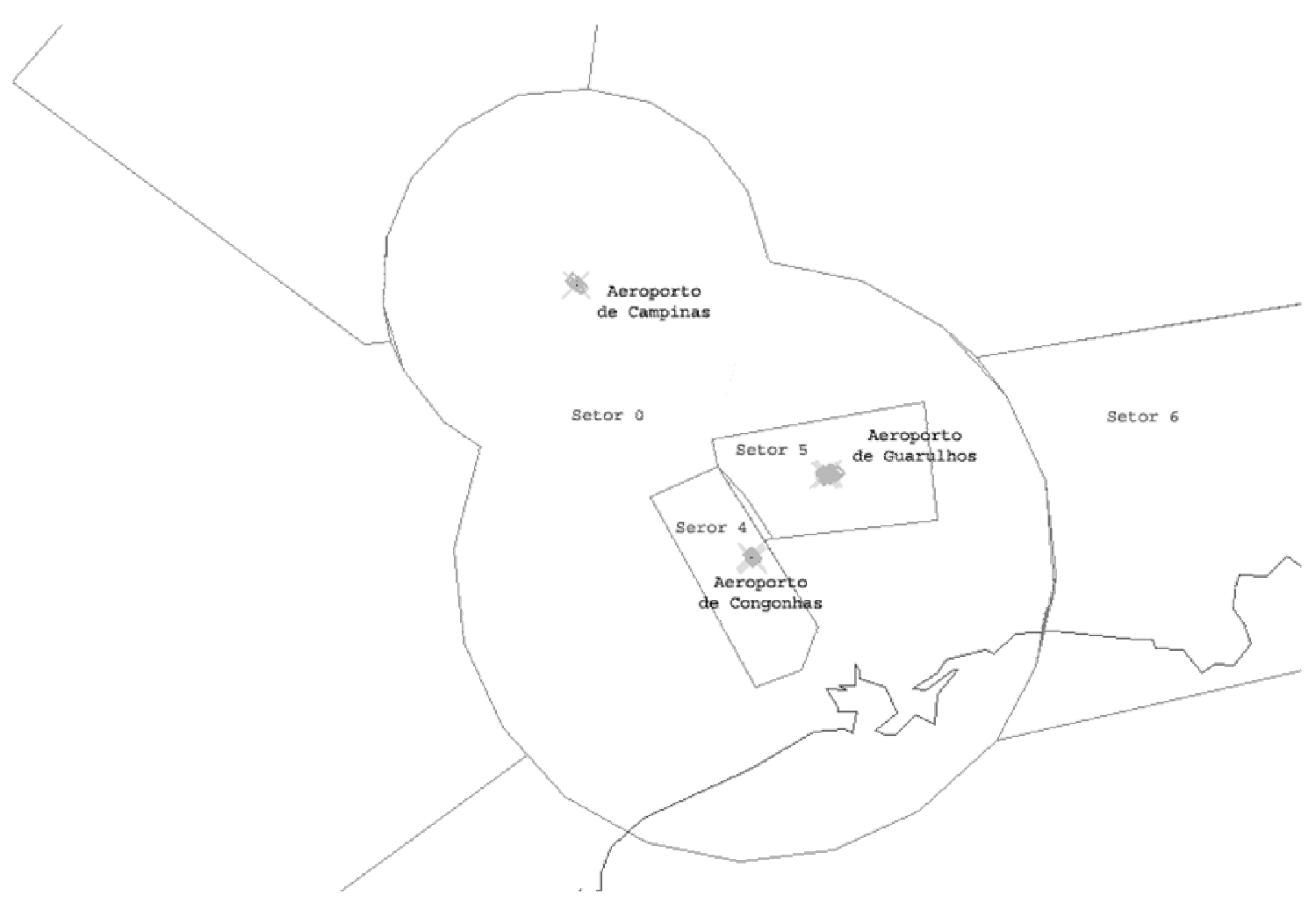

Figura 61 - Configuração da TMA-SP com agrupamento de setores.

A outra configuração criada foi para o período de alta densidade de aeronaves. Esta configuração foi efetuada a partir da divisão do setor 1 nos setores 1a e 1b, e do setor 2 nos setores $2 \mathrm{a}$ e $2 \mathrm{~b}$. Ela foi sugerida dentro do escopo das visitas realizadas ao APP-SP, durante a realização deste trabalho, e por meio de entrevistas junto a alguns controladores de tráfego aéreo. Os objetivos desta nova configuração é criar: a) uma separação do tráfego de pouso em Congonhas e Guarulhos, no setor 2; e b) isolar o tráfego de decolagem e pouso em Congonhas, no setor 1 .

Na configuração atual, o controlador de tráfego aéreo responsável pelo setor 2 controla os pousos que entram por este setor, tanto para o aeroporto de Congonhas como para o aeroporto de Guarulhos. Já o controlador de tráfego aéreo responsável pelo setor 1, controla tanto as decolagens como os pousos em Congonhas que saem ou entram pelo setor 1. Com esta nova configuração, o setor 2 é dividido em dois novos setores: o setor $2 \mathrm{a}$, responsável por controlar 
os pousos que entravam pelo setor 2 para Congonhas, e o setor $2 \mathrm{~b}$, responsável por controlar os pousos que entravam pelo setor 2 para Guarulhos. No caso do setor 1, ele também foi dividido isolando-se o fluxo de decolagem que era controlado pelo setor 1 , proveniente de Congonhas, no setor 1a, e de pouso que era controlado pelo setor 1 para Congonhas, no setor $1 b$, conforme ilustra a Figura 62.

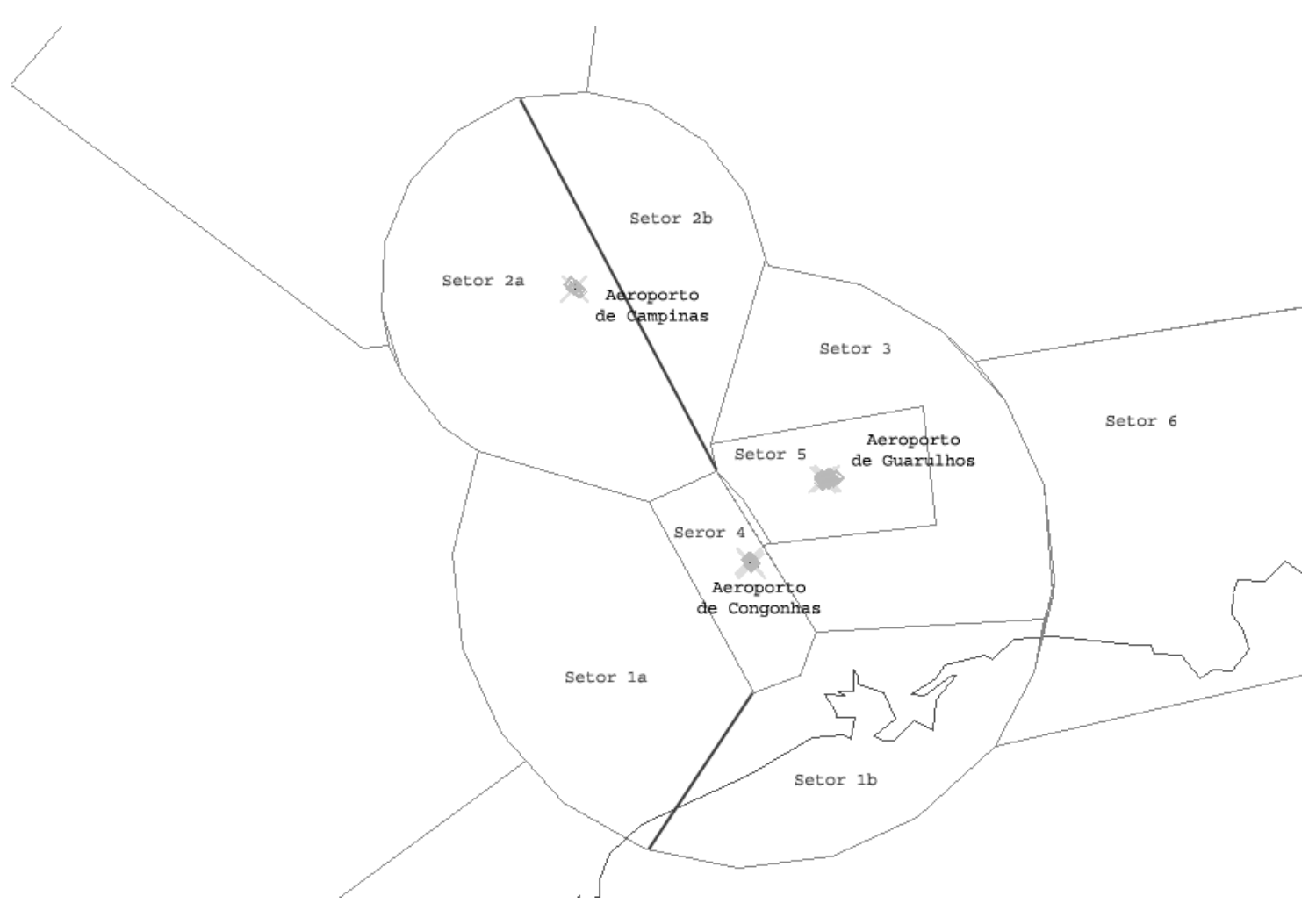

Figura 62 - Configuração da TMA-SP com divisão de setores.

Depois de definidas as possíveis configurações do espaço aéreo da TMA-SP e o tráfego a ser utilizados para as simulações, a próxima etapa consiste em se definir os momentos nos quais esses setores devem ser chaveados entre si. Para isso foi analisado o horário de funcionamento dos aeroportos envolvidos (SBGR, SBSP e SBKP) e qual o número de aeronaves por hora previstas nestes aeroportos, levando-se em conta os horários de pouso e decolagem. Vale ressaltar que todo o horário utilizado na simulação está baseado na Hora de Greenwich (três horas adiantado em relação ao horário de Brasília), pois ele é um horário universalmente aceito e a conversão dele é direta para o horário local.

No caso dos aeroportos SBSP e SBKP, seus horários de funcionamento vão das 09:00 as 02:00 (06:00 as 23:00 no horário de Brasília). Já o aeroporto de Guarulhos funciona 24 horas, 
ininterruptamente, porém com baixa densidade de aeronaves durante o período da madrugada. Assim, um ótimo momento para usar a configuração de baixa demanda é no período das 02:00 as 08:59 (23:00 as 5:59, do dia seguinte, referentes ao horário de Brasília). Essa configuração, de baixa demanda, será chamada de Configuração1. A Figura 61 ilustra essa configuração (configuração do espaço aéreo da TMA-SP, com agrupamento de setores).

Já a configuração para alta demanda foi utilizada nos momentos de pico das 00:00 às 01:59, das 11:00 as 14:59 e das 19:00 as 23:59. Essa configuração é detalhada na Figura 62 (configuração do espaço aéreo da TMA-SP, com divisão de setores) e será chamada de

\section{Configuração2.}

Os períodos restantes, das 09:00 as 10:59 e das 15:00 as 18:59, permaneceram com a configuração atual dos setores. Essa configuração é ilustrada na Figura 60 (configuração atual do espaço aéreo da TMA-SP) e será chamada de Configuração3.

Pode-se observar que os intervalos entre 19:00 as 23:59 de um dia e 00:00 as 01:59 do dia seguinte correspondem a um único intervalo. A Figura 63 ilustra o período do dia em que cada uma das três configurações ficará ativa para os estudos de caso utilizando a RDL.

\begin{tabular}{|c|c|c|c|c|c|}
\hline 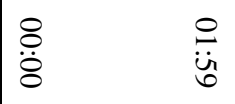 & $\begin{array}{l}\stackrel{P}{0} \\
\ddot{8}\end{array}$ & $\begin{array}{l}8 \\
\dot{8}\end{array}$ & $\overrightarrow{\stackrel{\overrightarrow{f i}}{\text { it }}}$ & $\begin{array}{l}\vec{\infty} \\
\dot{i}\end{array}$ & $\begin{array}{l}\text { ठ̊ } \\
\ddot{8}\end{array}$ \\
\hline Configuração2 & Configuração1 & Configuração3 & Configuração2 & Configuração3 & Configuração2 \\
\hline
\end{tabular}

Figura 63 - Alocação das configurações de setores ao espaço aéreo durante um dia, usando a RDL.

Para as simulações foram selecionas 7 das principais tarefas (vide Tabela 4) realizadas pelo controlador de tráfego aéreo, a saber:

- Recebendo a Primeira Chamada na Freqüência (Rx1CF);

- Recebendo Confirmação de Nível de Vôo Alcançado (RxCFL);

- Recebendo Handoff (RxHoff);

- Transmitindo Handoff (TxHoff);

- Transmitindo um Novo Nível de Vôo (TxNFL);

- Transmitindo uma Mudança de Freqüência (TxMF); e

- Removendo Vôos da Lista do Controlador (RemovVLC). 
Essas sete tarefas são realizas freqüentemente pelos controladores de tráfego aéreo. Existem outras tarefas, como comandos de vetoração, comandos de espera em vôo e mudanças de velocidades que são raramente empregadas em um espaço aéreo com as características utilizadas nesta investigação. Por este motivo foram considerados somente as sete principais tarefas realizadas pelo controlador de tráfego aéreo, descritas anteriormente.

Cada uma dessas tarefas foram programadas no RAMs Plus e são usadas nos estudos de caso apresentados neste capítulo. Para cada uma das tarefas foi associado um peso com a finalidade de medir o esforço do controlador para realizá-la. Os pesos descritos na Tabela 4 correspondem aos valores "default" disponibilizados pela ferramenta RAMs Plus e foram validados como "coerentes" nas entrevistas com os controladores de tráfego aéreo da APP-SP.

Tabela 4 - Tarefas realizadas pelo controlador nas simulações.

\begin{tabular}{|c|c|c|c|}
\hline Tarefa & Descrição & Abreviatura & Peso \\
\hline $\begin{array}{l}\text { Recebendo a Primeira } \\
\text { Chamada na Freqüência }\end{array}$ & $\begin{array}{l}\text { Isso ocorre quando o piloto entra pela primeira } \\
\text { vez em contato com o controlador do setor. }\end{array}$ & $\mathrm{Rx} 1 \mathrm{CF}$ & 8 \\
\hline $\begin{array}{l}\text { Recebendo Confirmação } \\
\text { de Nível de Vôo } \\
\text { Alcançado }\end{array}$ & $\begin{array}{l}\text { Isso ocorre quando o piloto informa ao } \\
\text { controlador quando um nível de vôo foi } \\
\text { alcançado. }\end{array}$ & $\mathrm{RxCFL}$ & 5 \\
\hline Recebendo Handoff & $\begin{array}{l}\text { Para o controlador, isso consiste em receber a } \\
\text { transferência de tráfego de um setor para outro } \\
\text { adjacente. Existem duas formas de receber } \\
\text { Handoff: uma automática, quando o controlador } \\
\text { em sua tela clica sobre a aeronave que está } \\
\text { chegando ao setor, informando que está pronto } \\
\text { e ciente para receber esta aeronave, e outra } \\
\text { quando o controlador recebe uma chamada de } \\
\text { outro controlador de um centro de controle } \\
\text { adjacente, informando que está sendo passado o } \\
\text { tráfego. }\end{array}$ & RxHoff & 5 \\
\hline Transmitindo Handoff & $\begin{array}{l}\text { Consiste em transmitir a transferência de } \\
\text { tráfego de um setor para outro adjacente. }\end{array}$ & TxHoff & 8 \\
\hline $\begin{array}{l}\text { Transmitindo um Novo } \\
\text { Nível de Vôo }\end{array}$ & $\begin{array}{l}\text { Isso ocorre quando o controlador pede para o } \\
\text { piloto mudar para outro nível de vôo. }\end{array}$ & TxNFL & 10 \\
\hline $\begin{array}{l}\text { Transmitindo uma } \\
\text { Mudança de Freqüência }\end{array}$ & $\begin{array}{l}\text { Isso ocorre quando o controlador pede para o } \\
\text { piloto mudar para outra freqüência de } \\
\text { comunicação ou quando ele transfere o tráfego } \\
\text { e informa ao piloto para contatar o controlador } \\
\text { do setor adjacente em uma dada freqüência. }\end{array}$ & TxMF & 5 \\
\hline $\begin{array}{l}\text { Removendo Vôos da Lista } \\
\text { do Controlador }\end{array}$ & $\begin{array}{l}\text { Esta tarefa do controlador consiste em remover } \\
\text { as fichas de progressão de vôo. Este } \\
\text { procedimento acontece quando é finalizada a } \\
\text { transferência do tráfego para outro adjacente. }\end{array}$ & RemovVLC & 3 \\
\hline
\end{tabular}


Vale ressaltar que, caso seja necessário aplicar outros pesos às tarefas contabilizadas na carga de trabalho dos controladores de tráfego aéreo apresentados nesta investigação, não é necessário realizar novamente a simulação, mas basta dividir o resultado de cada tarefa pelo peso utilizado e multiplicar pelo novo peso que se deseja utilizar.

\subsection{Estudo de Caso 1: Tráfego Atual com Alta Densidade de Aeronaves}

O primeiro caso a ser estudado é o uso da re-setorização dinâmica para um tráfego real com alta densidade de aeronaves. Segundo os responsáveis pelo controle de tráfego aéreo do APPSP, o dia no ano de 2006 que caracterizou o cenário com alta demanda de aeronaves na TMASP foi 30 de Agosto de 2006.

A Figura 64 ilustra a distribuição do número de pouso e decolagem por hora nos aeroportos da TMA-SP após realizar os tratamentos dos dados descritos no início deste capítulo. É possível observar também nessa figura o momento em que cada uma das configurações estão ativas na RDL durante o dia e comparar o tipo de configuração usada com o volume de aeronaves. A configuração 1 (Config1), configuração desenhada para o período de baixa demanda de aeronaves, teve uma demanda de aeronaves variando de 8 a 18 aeronaves. A demanda de aeronaves na configuração 2 (Config2), configuração desenhada para o período de alta demanda de aeronave, variou de 54 a 73 aeronaves. Já a configuração 3 (Config3), configuração atual da TMA-SP, teve a demanda de aeronaves variando de 43 a 61 aeronaves.

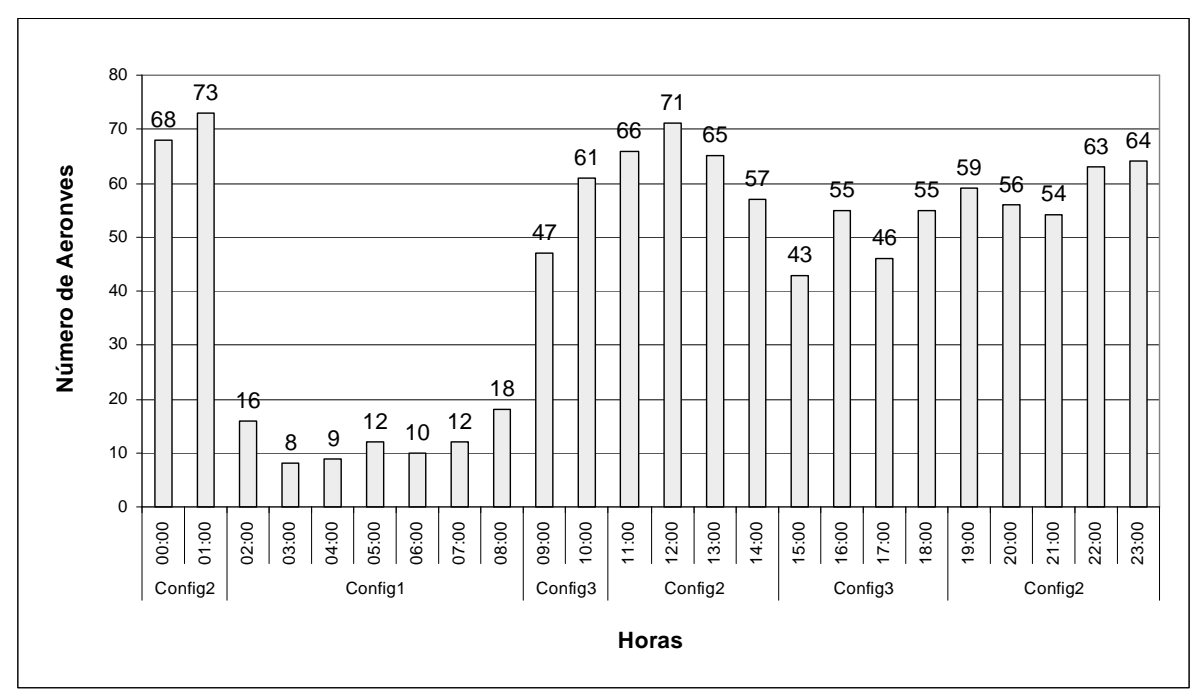

Figura 64 - Movimento de aeronaves (vôos IFR) na TMA-SP, em 30/08/2006. 
O RAMS Plus não disponibiliza relatórios gráficos como resultado das simulações, mas vários arquivos de texto formatados com os registros gerados durante a simulação. Estes arquivos precisam ser tratados por ferramentas computacionais a fim de se construir qualquer tipo de relatório.

A apresentação e análise dos resultados deste estudo de caso é dividida em quatro partes, a saber:

- Análise da Carga de Trabalho do Controlador de Tráfego Aéreo;

- Análise do Número de Conflitos em Potencial;

- Análise da Função Complexidade; e

- Análise do Número de Aeronaves Controladas Simultaneamente pelo Controlador de Tráfego Aéreo.

\subsubsection{Análise da Carga de Trabalho do Controlador de Tráfego Aéreo}

Na TMA-SP, os setores 4 e 5 controlam apenas as aeronaves que estão pousando em seus respectivos aeroportos: SBSP (Congonhas) e SBGR (Guarulhos). Contudo, quando uma aeronave decola do aeroporto SBSP ou SBGR, ao invés de chamar o controlador do setor 4 ou 5 , pois estes setores estão sobre a região do espaço destes aeroportos, ela chama o controlador do setor 1 ou 3, adjacentes a estes setores. Não foi possível criar diretamente este cenário com setores sobrepostos utilizando a ferramenta RAMS Plus empregada nas simulações computacionais, pois as aeronaves que partiram de SBSP e SBGR foram controladas primeiramente pelos setores 4 e 5 , respectivamente, e depois transferidas para os setores 1 e 3 . Na configuração real da TMA-SP os setores 4 e 5 não devem receber essas aeronaves.

Analisando os resultados após simulação, constatou-se que as tarefas associadas aos controladores dos setores 4 e 5, considerando apenas os vôos que decolaram de SBSP ou SBGR, eram em sua totalidade referentes às funções de "receber" e "transmitir" tráfego. De forma mais detalhada, os controladores dos setores 4 e 5, nas simulações, em relação à decolagem de SBSP e SBGR, realizaram as seguintes tarefas: Recebendo Handoff (da TWR) e Recebendo a Primeira Chamada na Freqüência (da aeronave), tarefas estas relacionadas com o "recebimento" de tráfego aéreo, e Transmitindo uma Mudança de Freqüência (para 
a aeronave), Transmitindo Handoff (para outro setor do APP-SP) e Removendo Vôos da Lista do Controlador, tarefas estas relacionadas com a "transmissão" de tráfego.

Outro ponto a ser destacado é que esses vôos de partida foram controlados primeiramente pelos setores 4 ou 5 e, depois, transferidos para os setores 1 ou 3, respectivamente. Para normalizar a carga de trabalho dos controladores de cada setor, as cargas de trabalho dos controladores, referentes aos vôos que decolaram dos aeroportos SBSP e SBGR, e contabilizadas indevidamente para os setores 4 e 5, foram subtraídas das cargas de trabalho total destes controladores, obtidas por meio das simulações computacionais. Não foi necessário acrescentar alguma carga ao controle dos setores 1 ou 3, pois na simulação já estava incluso nestes setores a carga de trabalho que seus controladores sofreram ao receber as aeronaves dos setores 4 ou 5. Com este artifício, tornou-se possível reproduzir indiretamente o cenário real da TMA-SP em que as aeronaves que decolam de SBSP e SBGR chamam diretamente o controle dos setores 1 ou 3. A Figura 65 e a Figura 66 ilustram o comportamento da carga de trabalho dos controladores de tráfego aéreo, respectivamente, para os cenários sem e com o uso da RDL.

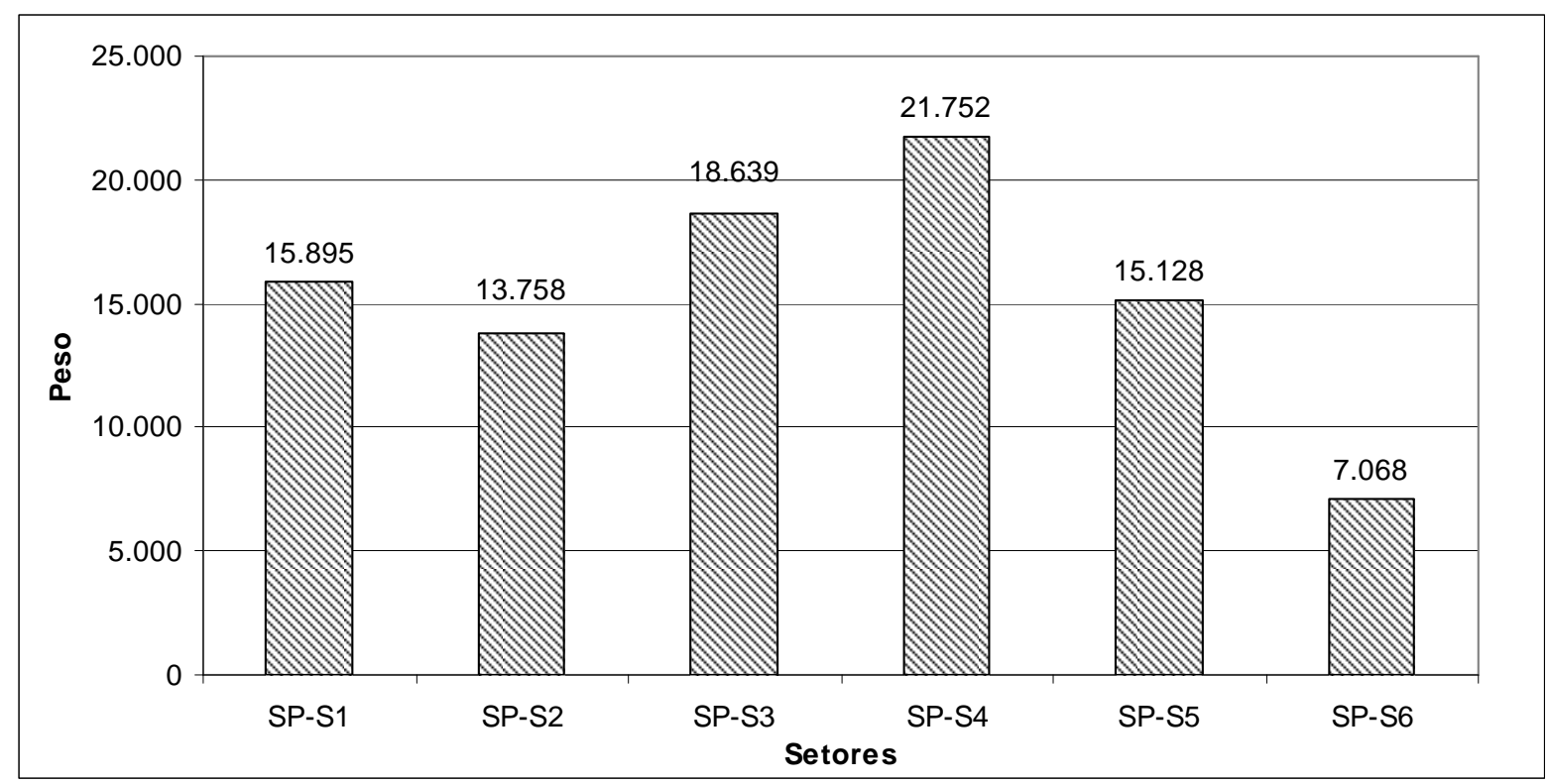

Figura 65 - Soma dos pesos das tarefas realizadas pelos controladores de tráfego aéreo, por setor, sem o uso da RDL, durante o dia 30/08/2006. 


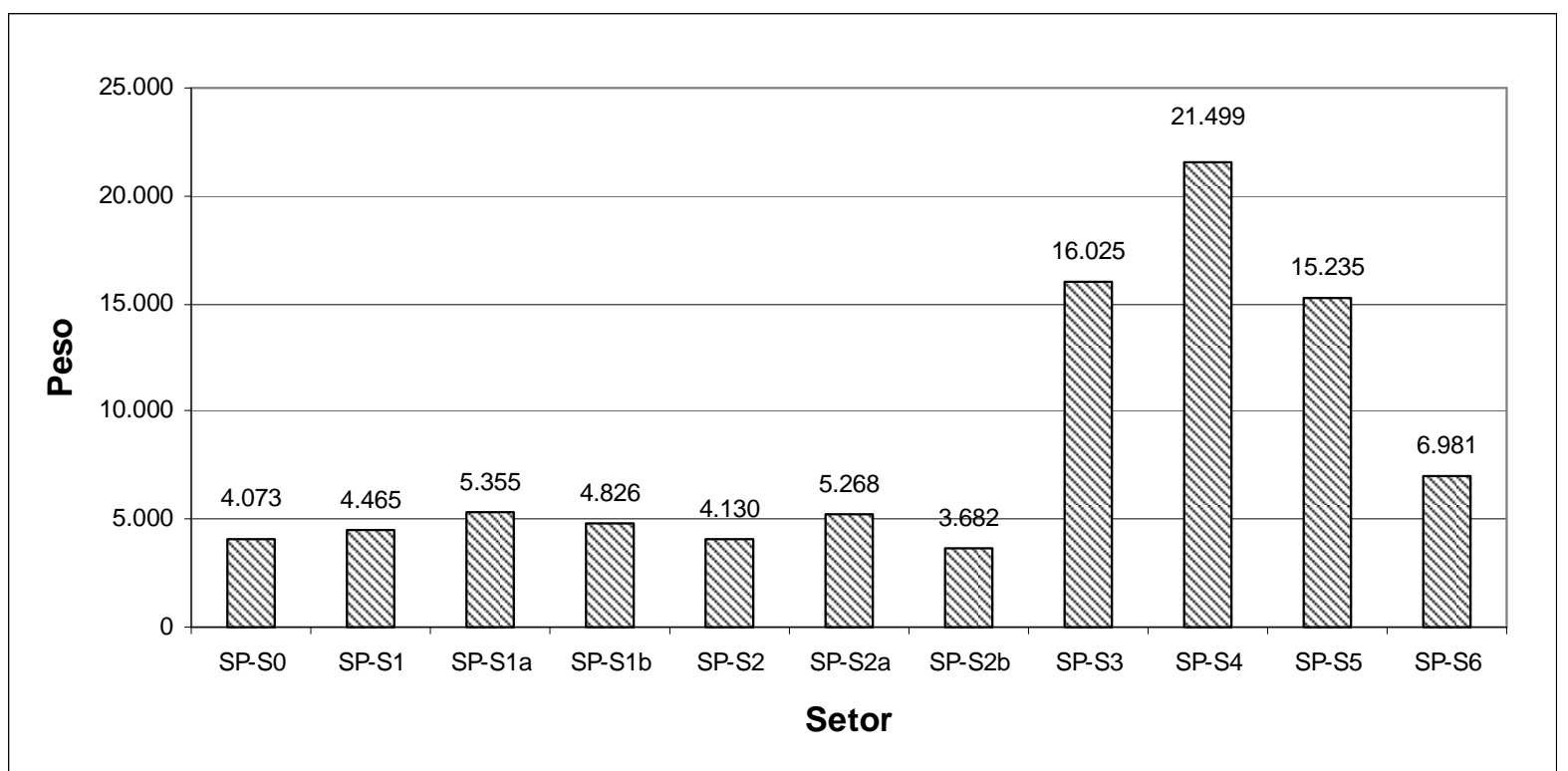

Figura 66 - Soma dos pesos das tarefas realizadas pelos controladores de tráfego aéreo, por setor, com o uso da RDL, durante o dia 30/08/2006.

Os resultados destes gráficos expressam qual a somatória dos pesos de todas as tarefas realizadas pelos controladores de tráfego aéreo de cada um dos setores durante a simulação computacional. No decorrer do vôo de uma aeronave, durante a simulação, são gerados eventos. Esses eventos são associados às tarefas que são desempenhadas por um controlador de tráfego aéreo e estão descritas na Tabela 4. Para cada evento gerado, a ferramenta grava: a tarefa associada ao evento, qual controlador executou a tarefa e qual o peso referente a tarefa. Os gráficos ilustrados na Figura 65 e na Figura 66 representam a somatória dos pesos associados a cada tarefa, por setor, contabilizada durante a simulação.

Como ilustra a Figura 66, houve uma distribuição da carga de trabalho com o uso da RDL entre os setores 1 e 2, setores que sofreram re-configuração durante a simulação. Com a divisão dos setores 1 e 2 (criando 4 novos setores), a carga de trabalho por setor durante o momento de pico, que antes chegava até a 15.895 pontos no setor 1 e 13.758 no setor 2 , sem o uso da RDL (Figura 65), não passou de 5.355 com o uso da RDL (Figura 66) nos novos setores frutos da divisão dos setores 1 e 2 originais (valor máximo no setor 1a).

Outro ponto a ser destacado é que mesmos os setores que não sofreram quaisquer tipos de mudança em suas configurações, com exceção do setor 5, apresentaram uma ligeira diminuição na somatória da carga de trabalho com o uso da RDL. 
A Figura 67 ilustra com mais detalhe a carga de trabalho do controlador de tráfego aéreo no setor 1, com e sem o uso da RDL. Para cada hora do dia foi somada a carga de trabalho do setor 1, sem o uso da RDL, e dos setores 1, 1a, 1b, com o uso da RDL.

Na simulação com o uso da RDL os setores $1 \mathrm{a}$ e $1 \mathrm{~b}$ não coexistem com o setor 1 . Já na simulação sem o uso da RDL, o setor 1 prevalece durante todas as horas do dia. Durante período das 02:00 às 08:59 só existe o setor 0, que será estudado separadamente.

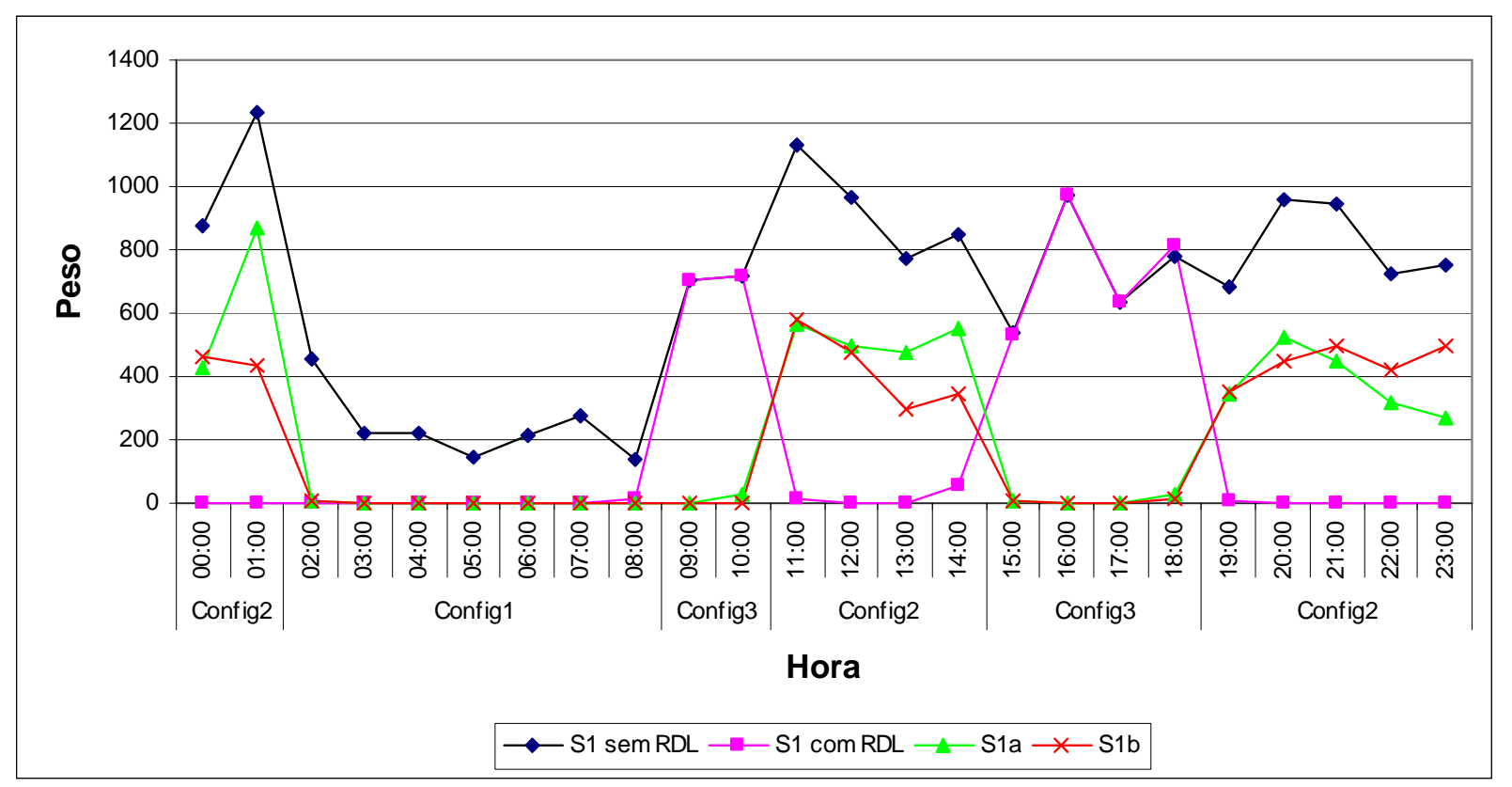

Figura 67 - Soma, por hora, dos pesos das tarefas realizadas pelos controladores nos setores 1, 1a e 1b,

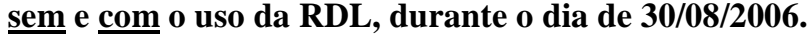

Da mesma forma, a Figura 68 ilustra a carga de trabalho do controlador de tráfego aéreo no setor 2, com e sem o uso da RDL. Para cada hora do dia foi somada a carga de trabalho no setor 2, sem o uso da RDL, e nos setores 2, 2 a e 2b, com o uso da RDL. Na simulação com o uso da RDL os setores $2 \mathrm{a}$ e $2 \mathrm{~b}$ não coexistem com o setor 2. Durante período das 02:00 as 08:59 só existe o setor 0, que será estudado separadamente. 


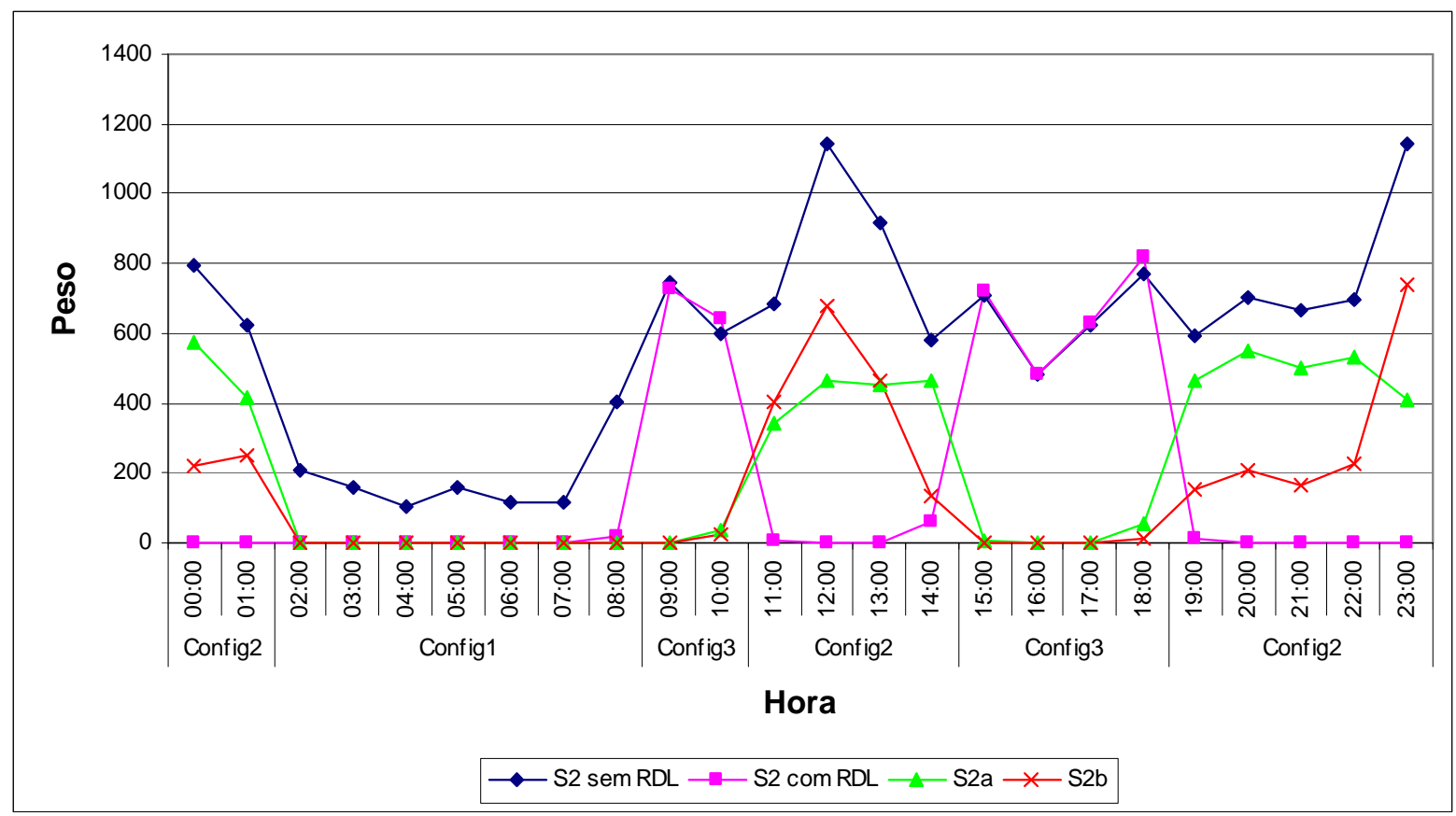

Figura 68 - Soma, por hora, dos pesos das tarefas realizadas pelo controlador nos setores 2, 2a e 2b, sem e com o uso da RDL, durante o dia de 30/08/2006.

Segundo os gráficos ilustrados na Figura 67 e na Figura 68, o uso da RDL conseguiu reduzir a carga de trabalho do controlador de tráfego aéreo durante os momentos de pico nos períodos das 11:00 as 14:59 e das 22:00 as 23:59, e também para os outros períodos em que os setores $1 \mathrm{a}, 1 \mathrm{~b}, 2 \mathrm{a}$ e $2 \mathrm{~b}$ estiveram ativos.

Comparando a carga de trabalho dos controladores durante o período em que a configuração atual do espaço aéreo esteve ativa, das 09:00 as 10:59 e das 15:00 as 18:59, o uso da RDL não provocou um aumento na carga de trabalho dos controladores nesses períodos.

Na simulação com o uso da RDL, durante o período das 02:00 as 08:59, os setores 1, 2 e 3 foram agrupados no setor 0 . A análise dos dados do setor 0 após a simulação teve que sofrer uma adequação a fim de representar a situação real de tráfego aéreo. Ou seja, não foi possível cria o setor 0 sem que os setores 4 e 5 estivessem contidos nesse setor, pois o software RAMS Plus não possibilita criar um setor contido em outro setor sem que uma borda do setor interno tenha ligação com o setor externo, como no caso da configuração proposta para os setores 0,4 e 5, ilustrada na Figura 61. O software assumiu que a região do espaço controlada pelo controlador do setor 4 e pelo controlador do setor 5 também era controlada pelo controlador do setor 0 . Essa incongruência resultou que o controlador do setor 0 acabou por absolver parte da carga de trabalho dos controladores do setor 4 e 5 . 
Para ajustar os resultados da carga de trabalho obtidos na simulação com o uso da RDL, foi analisada hora a hora como a carga de trabalho dos controladores dos setores 4 e 5 se comportavam, com e sem o uso da RDL. Os resultados mostraram que nos horários em que não houve chaveamento de configuração com o uso da RDL, a carga de trabalho dos controladores dos setores 4 e 5 se manteve constante, com exceção do período das 02:00 as 08:59. Nesse período, das 02:00 as 08:59, a carga de trabalho dos controladores dos setores 4 e 5 ficou bem mais baixa na simulação com o uso da RDL, se comparada com a carga de trabalho dos controladores dos setores 4 e 5 sem o uso da RDL. Com isso foi possível concluir que o controlador do setor 0 estava absorvendo, no período das 02:00 as 08:59, parte da carga de trabalho dos controladores dos setores 4 e 5 .

Como solução de contorno, para o período das 02:00 as 08:59, foi subtraída da carga de trabalho do controlador do setor 0 justamente o que faltava na carga de trabalho dos controladores dos setores 4 e 5 com o uso da RDL, se comparado com a carga de trabalho atribuída aos controladores dos setores 4 e 5 sem o uso da RDL. Após esse ajuste necessário, chegou-se o gráfico ilustrado na Figura 69.

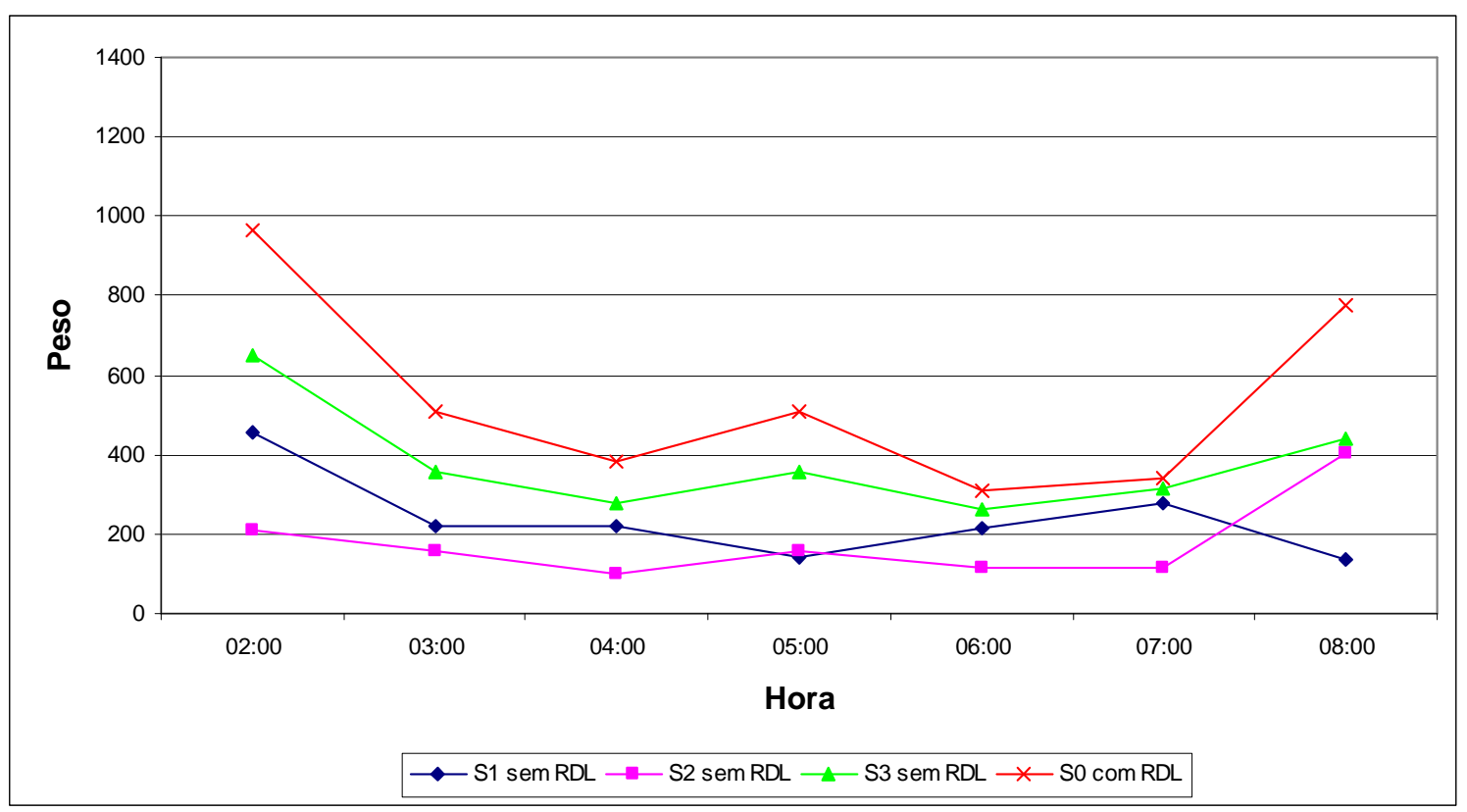

Figura 69 - Soma, por hora, dos pesos das tarefas realizadas pelo controlador de tráfego aéreo nos setores 0, 1, 2 e 3, sem e com o uso da RDL, durante a madrugada do dia de 30/08/2006.

O gráfico ilustrado na Figura 69 representa a carga de trabalho, por hora, atribuída ao controlador do setor 0 , formado pela união dos setores 1,2 e 3 na simulação com o uso da 
RDL, e dos controladores dos setores 1, 2 e 3, sem o uso da RDL, no período das 02:00 as 08:59.

O objetivo de se agrupar os setores 1, 2 e 3 no setor 0 é otimizar o controle do tráfego durante o período de baixa demanda de aeronaves. Comparando-se o gráfico da Figura 69 com os gráficos das Figura 67 e Figura 68, a carga de trabalho atribuída ao setor 0 no maior período do tempo, das 03:00 as 07:59, ficou abaixo dos picos das cargas de trabalho atribuídas aos controladores dos setores 1, 1a, 1b, 2, 2a e 2b, com o uso da RDL, e do controladores dos setores 1 e 2, sem o uso da RDL. O período das 02:00 as 02:59 e das 08:00 as 08:59 horas foi onde a carga de trabalho do controlador do setor 0 teve maior valor. Contudo, durante esse período, a carga de trabalho total do controlador do setor 0 não ultrapassou o pico da carga de trabalho atribuída aos controladores dos setores 1 na simulação com o uso da RDL ilustrada na Figura 67.

Como conclusão, durante as simulações computacionais, a união dos setores 1,2 e 3 em um único setor (setor 0) proporcionou que um único controlador de tráfego aéreo ficasse responsável pelo tráfego corrente dos setores 1, 2 e 3, sem que a carga de trabalho atribuída a este controlador de tráfego aéreo fosse maior que o pico da carga atribuída individualmente aos outros controladores com o uso da RDL.

Outro ponto relevante que auxilia o controle do setor 0 é o seu tamanho. Com uma região maior do espaço com menor demanda de tráfego aéreo, se comparado com a demanda do período em que os aeroportos SBSP e SBKP estão abertos, a gestão do tráfego tende a ficar mais facilitada, pois com um menor número de aeronaves sobre um espaço mais amplo, o controlador de tráfego aéreo consegue manter com maior facilidade as aeronaves distantes uma das outras, o que vai a favor da segurança.

Subtraindo o resultado da soma de todas as tarefas realizadas por hora, nas simulações computacionais realizadas na TMA-SP, sem o uso da RDL, do resultado da soma dos pesos de todas as tarefas realizadas por hora, com o uso da RDL, foi possível construir o gráfico ilustrado pela Figura 70. Os resultados positivos deste gráfico representam que a carga de trabalho atribuída a TMA-SP sem o uso da RDL é maior que com o uso da RDL. No período, das 02:00 as 08:59, quando esteve ativo o setor 0, o uso da RDL proporcionou uma menor carga de trabalho global na TMA-SP. Justamente nos períodos em que existe o chaveamento das configurações dos setores, das 01:00 as 01:59, das 08:00 as 08:59, das 10:00 as 10:59, das 14:00 as 14:59 e das 18:00 as 18:59, existe um aumento na carga de trabalho dos controladores com o uso da RDL. Isso ocorre porque com o uso da RDL existe a divisão ou 
agrupamento de setores e, no período que ocorre a mudança de configuração, o controle das aeronaves precisa ser transmitido e recebido pelos controladores de tráfego aéreo responsáveis pelos novos setores.

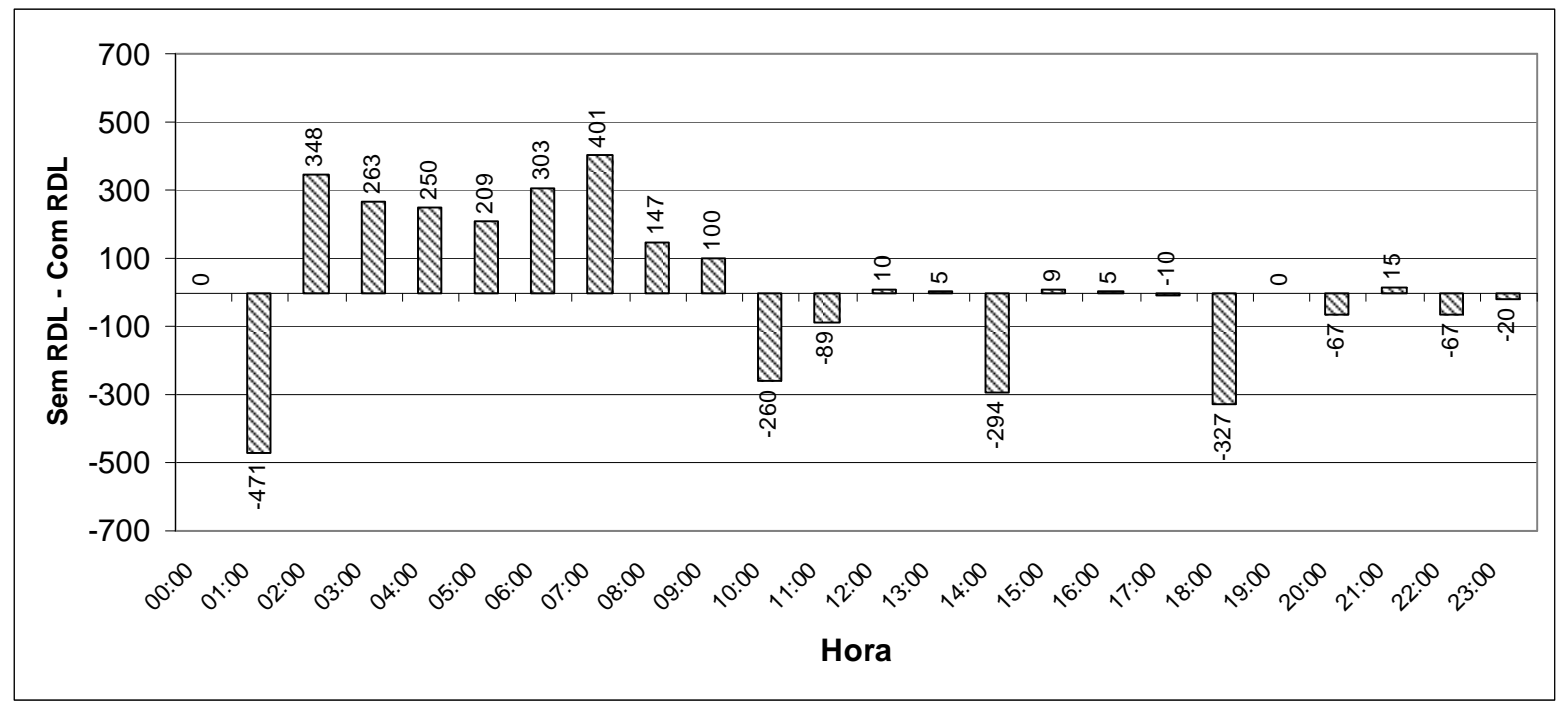

Figura 70 - Diferença entre os pesos das tarefas realizadas pelo controlador de tráfego aéreo, $\underline{\text { sem e com o }}$ o uso da RDL, por hora, durante o dia 30/08/2006.

O gráfico apresentado na Figura 71 representa a somatória de todos os pesos, por tarefas cumpridas pelos controladores de tráfego aéreo, durante as simulações computacionais. Comparando o valor total por tarefas realizadas pelos controladores durante a simulação, com e sem o uso da RDL, não existe uma variação significativa entre eles. Segundo este gráfico, para as configurações propostas, não houve um aumento na carga de trabalho global dos controladores de tráfego aéreo do APP-SP devido ao uso da RDL. Dois fatores contribuíram para esse resultado. Primeiro, a divisão feitas nos setores 1 e 2 foram sempre longitudinalmente às rotas dos setores e, como conseqüência, a re-setorização não provocou um aumento na transferência de aeronaves entre os setores. Segundo, houve uma diminuição na transferência de aeronaves entre os setores devido ao agrupamento dos setores 1,2 e 3 durante a madrugada. 


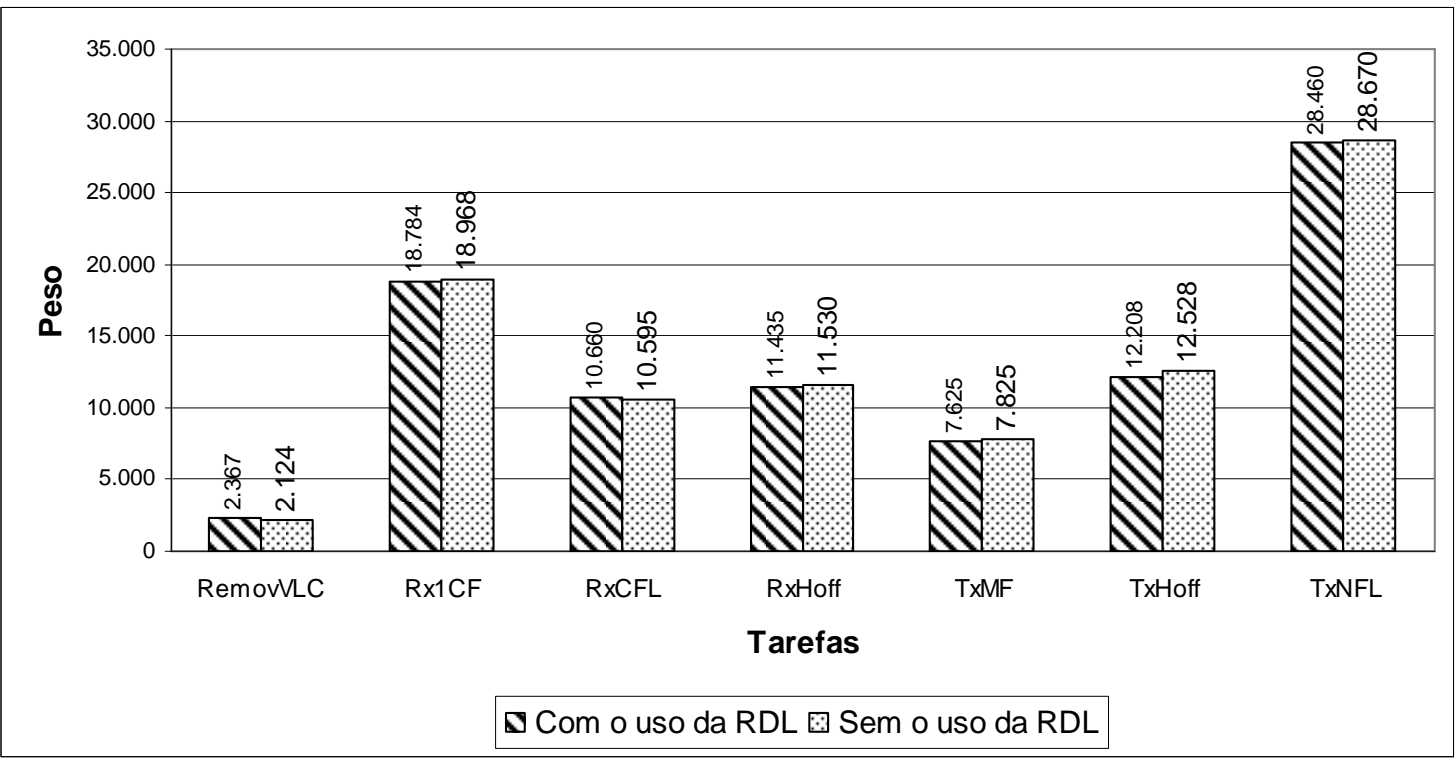

Figura 71 - Soma dos pesos das tarefas realizadas pelo controlador, com e sem o uso da RDL, durante 0 dia 30/08/2006.

Analisando o gráfico ilustrado pela Figura 71 surge o seguinte questionamento: o resultado da divisão dos valores referente a cada tarefa, expressos nessa figura, pelo peso adotado para cada tarefa, corresponde ao número de ocorrências dessas tarefas nas simulações. Então, por exemplo, por quê o número de ocorrências das tarefas Recebendo Handoff - RxHoff, de peso 5 (2287 com o uso da RDL e 2306 sem o uso da RDL) e Transmitindo Handoff - TxHoff, de peso 8 (1526 com o uso da RDL e 1566 sem o uso da RDL), não têm o mesmo valor, assim como Recebendo Confirmação de Nível de Vôo Alcançado - RxCFL, de peso 5 (2132 com o uso da RDL e 2119 sem o uso da RDL) e Transmitindo um Novo Nível de Vôo - TxNFL, de peso 10 (2846 com o uso da RDL e 2867 sem o uso da RDL), já que são tarefas complementares?

Para responder essa pergunta, primeiro é necessário mencionar que as simulações realizadas neste trabalho de investigação científica abordaram somente a área da TMA-SP. Nenhum vôo realiza o seu ciclo completo, tendo um aeroporto de partida e um aeroporto de chegada no percurso acompanhado, ou vice-versa. O destino é sempre um aeroporto da TMA-SP ou um ponto fixo, enquanto a origem é um aeroporto da TMA-SP ou um ponto fixo. Este contexto pode ser observado na Figura 53. Logo, como nas simulações os vôos não realizavam seu ciclo completo, o número de ocorrência para as tarefas complementares não foram os mesmos.

Como conclusão desta análise, em relação a carga de trabalho do controlador de tráfego aéreo, são apresentados dois pontos: a) o uso da RDL proporcionou uma otimização da carga de 
trabalho do controlador de tráfego aéreo, se comparado com a simulação sem o uso da RDL; b) comparando os valores globais das tarefas realizadas pelos controladores de tráfego aéreo na TMA-SP, o uso da RDL não provocou um aumento nesse volume global, se comparado com a simulação sem o uso da RDL.

\subsubsection{Análise do Número de Conflitos em Potencial}

Nos resultados apresentados a seguir são levados em conta apenas os setores 1, 2, 3 e 6, para as simulações sem o uso da RDL, e os setores 1, 1a, 1b, 2, 2a, 2b, 3 e 6, para as simulações com o uso da RDL. Os dados referentes aos setores 0,4 e 5 não são apresentados, pois não puderam ser implementadas no RAMS Plus, conforme já descrito anteriormente.

Um ponto crítico na segurança do tráfego aéreo que impacta diretamente a carga de trabalho dos controladores de tráfego aéreo é a quantidade conflitos entre aeronaves existentes em um espaço aéreo. A Figura 72 e a Figura 73 ilustram a quantidade de conflitos detectados durante as simulações computacionais realizadas, com e sem o uso da RDL, respectivamente. Os resultados desses gráficos mostram que uma maior distribuição da carga de trabalho dos controladores, com o uso da RDL, proporcionou uma melhor gestão do tráfego e, por conseqüência, uma diminuição do número de conflitos em potencial na TMA-SP, se comparado com a simulação sem o uso da RDL.

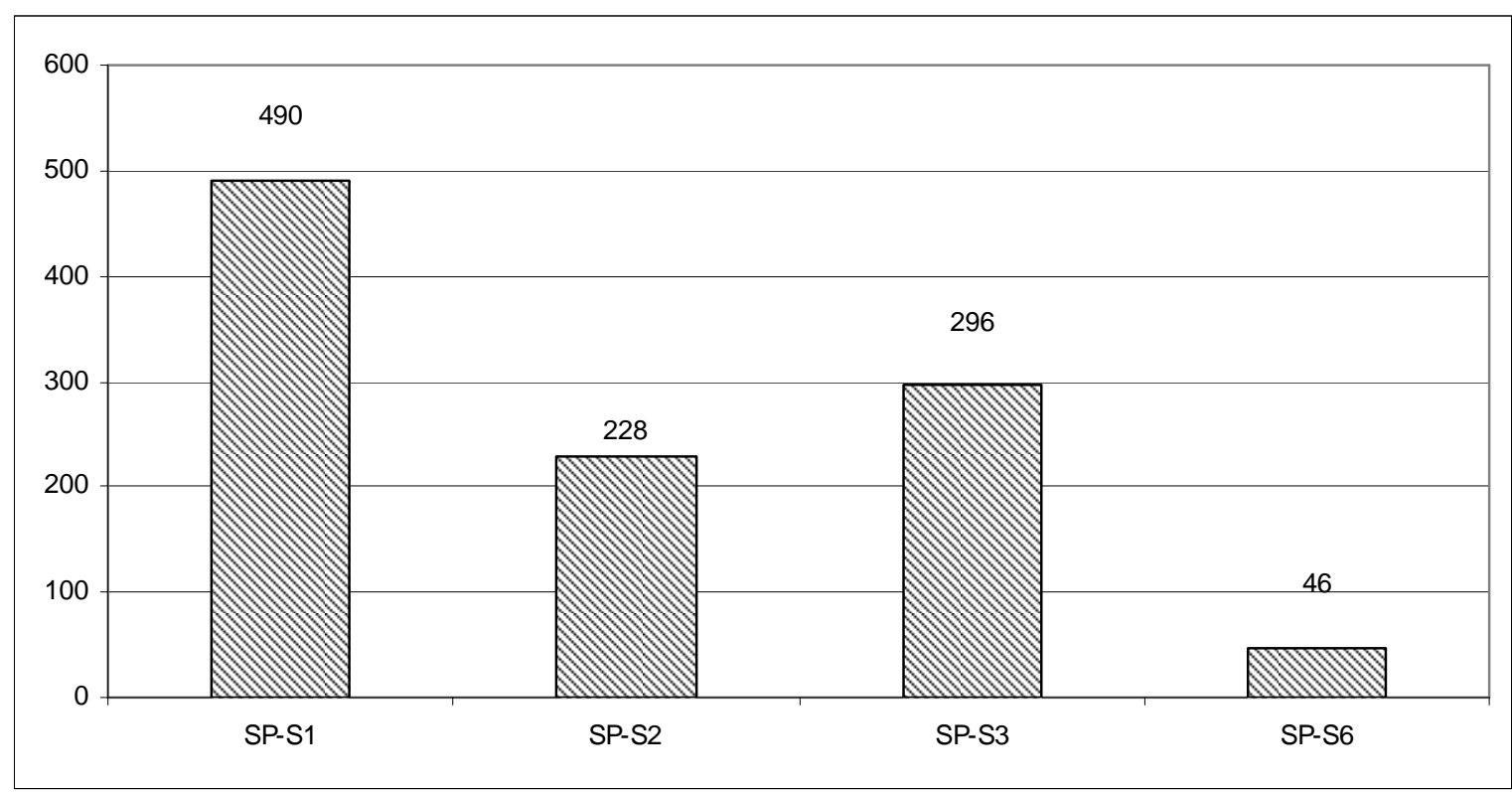

Figura 72 - Quantidade de conflitos detectados na TMA-SP, sem o uso da RDL, por setor, em 30/08/2006. 


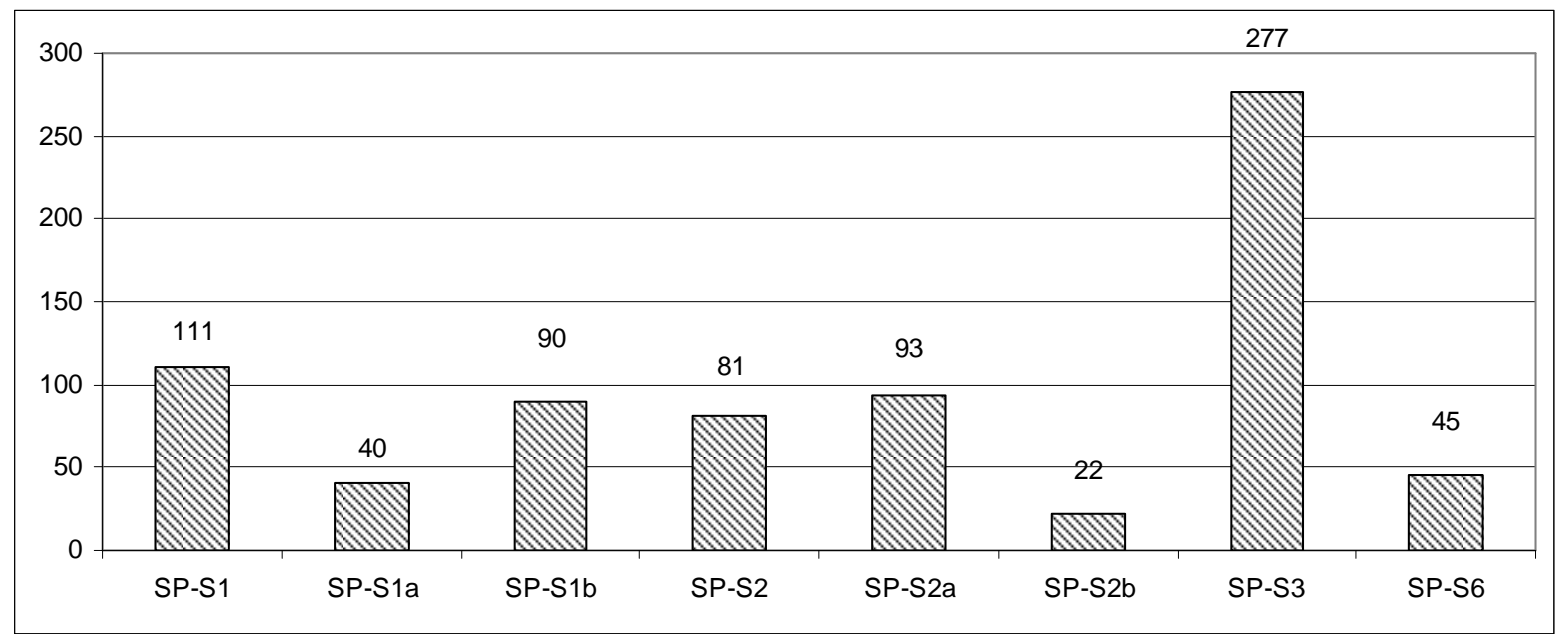

Figura 73 - Quantidade de conflitos detectados na TMA-SP, com o uso da RDL, por setor, em 30/08/2006.

Os 490 e 228 conflitos detectados, respectivamente, nos setores 1 e 2, que incidem diretamente na carga de trabalho de dois controladores por turno de trabalho, foram dissolvidos entre os novos setores criados com o uso da RDL, não ultrapassando 111 conflitos para o setor 1 e 93 para o setor 2a. Mesmos os setores que não sofreram re-configuração tiveram menos conflitos detectados.

Considerando a soma de todos conflitos de todos os setores da TMA-SP, houve uma redução de 44,1 conflitos detectados por hora na simulação sem uso da RDL, para 33,6 conflitos detectados por hora com o uso da RDL. Isso representa uma redução de aproximadamente 10,5 conflitos detectados a menos por hora com o uso da RDL, o que representa uma redução de $31 \%$. Isso se deve ao fato da RDL proporcionar uma melhor gestão do tráfego de aeronaves, não só para os setores que sofreram re-configuração, mas para toda TMA.

Como conclusão, o uso da RDL proporcionou uma redução do número de conflitos em potencial detectado na TMA-SP, se comparado com a simulação sem o uso da RDL.

\subsubsection{Análise da Função Complexidade}

Um ponto importante para investigar no uso da RDL consiste na comparação da variação da complexidade dos setores, nos cenários com e sem o uso da RDL. O uso da RDL por meio da re-setorização do espaço aéreo pode provocar uma variação no resultado produzido pela função complexidade dos setores. O RAMS Plus implementa o conceito do cálculo de 
complexidade elaborando pela NASA (NASA, 1996), conforme apresentado anteriormente no item 4.3. Durante a simulação, em cada período de tempo, o RAMS Plus calcula o fator de complexidade de cada setor. Os gráficos ilustrados na Figura 74 e na Figura 75 representam a média ponderada do resultado da função complexidade na TMA-SP, no dia considerado, com e sem o uso da RDL.

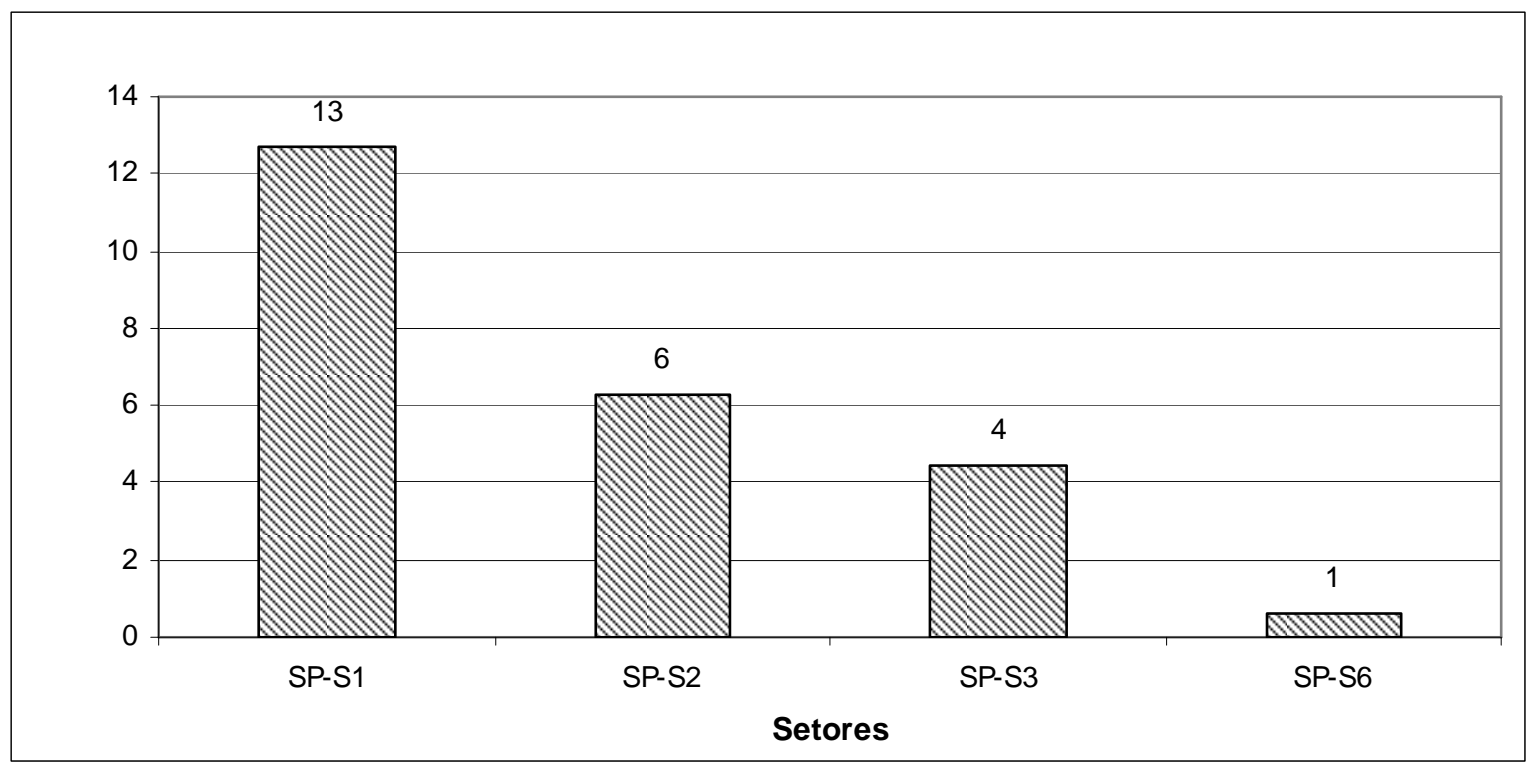

Figura 74 - Média ponderada do resultado da função de complexidade para a TMA-SP, $\underline{\text { sem }}$ o uso da DRL, por setor, para o dia 30/08/2006.

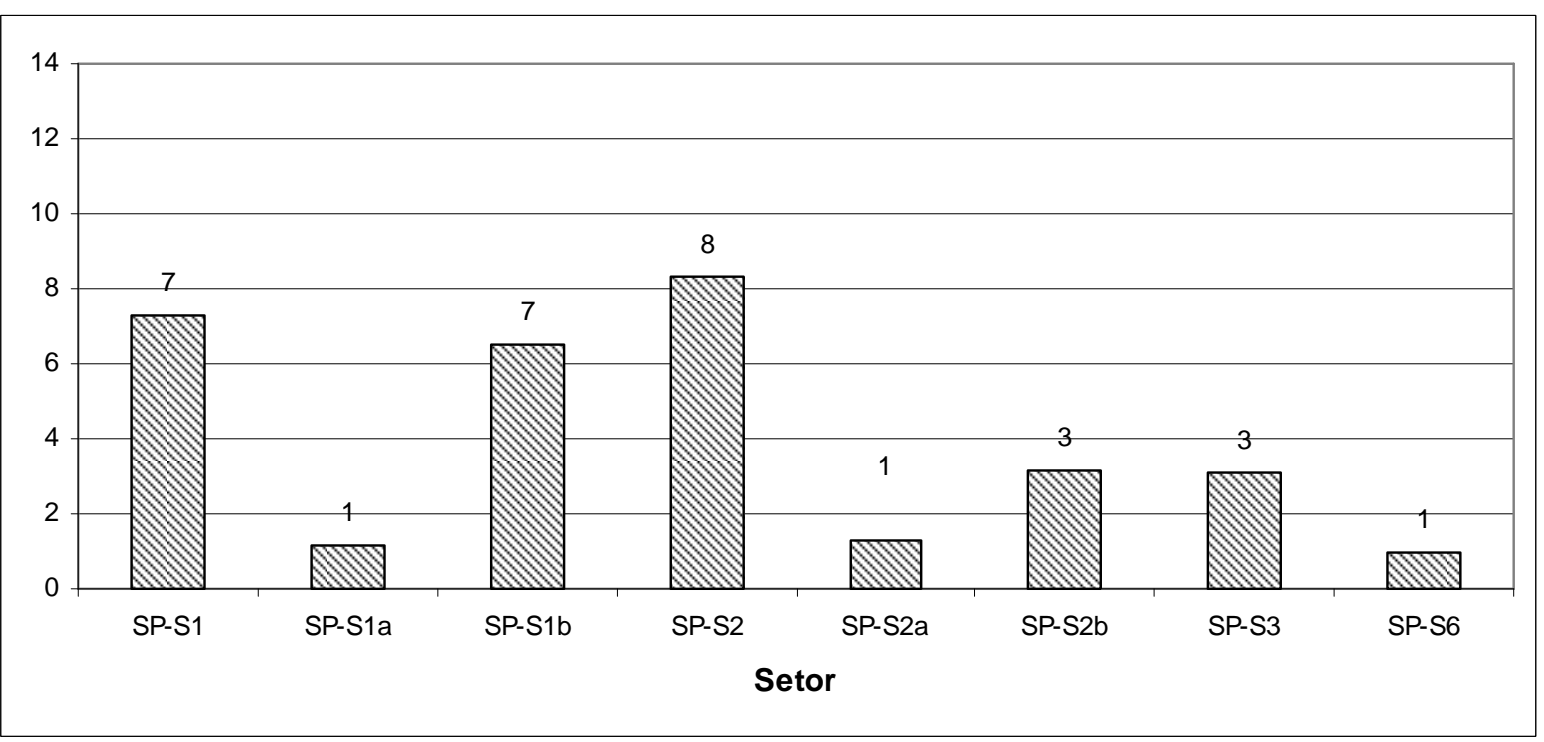

Figura 75 - Média ponderada do resultado da função de complexidade para a TMA-SP, com o uso da DRL, por setor, para o dia 30/08/2006. 
A divisão do setor 1 em 1a e 1b, e do setor 2 em $2 \mathrm{a}$ e $2 \mathrm{~b}$, com o uso da RDL, proporcionou uma menor complexidade destes setores, se comparado com a simulação sem o uso da RDL. Houve um aumento de $30 \%$ na média ponderada do resultado produzido pela função complexidade do setor 2 com o uso da RDL, se comparado com a média obtida para o setor 2 sem o uso da RDL. Para o setor 3, que não sofreu re-configuração, houve uma redução no resultado da média da função complexidade com o uso da RDL. No caso do setor 6, a média da função complexidade se manteve constante, com e sem o uso da RDL. Segundo as simulações, com exceção do setor 2 , o uso da RDL não proporcionou um aumento na média da função complexidade dos setores. A análise da função complexidade não foi realizada para os setores 0,4 e 5 pelos mesmos motivos descritos no item 5.2.1.

\subsubsection{Análise do Número de Aeronaves Controladas Simultaneamente pelo Controlador de Tráfego Aéreo}

A Figura 76 e a Figura 77 ilustram o número de aeronaves controladas simultaneamente por setor da TMA-SP, sem e com o uso da RDL. Segundo (DECEA, 2007), o número máximo de aeronaves suportadas simultaneamente nos setores 1,2 e 3 é de 8 aeronaves.

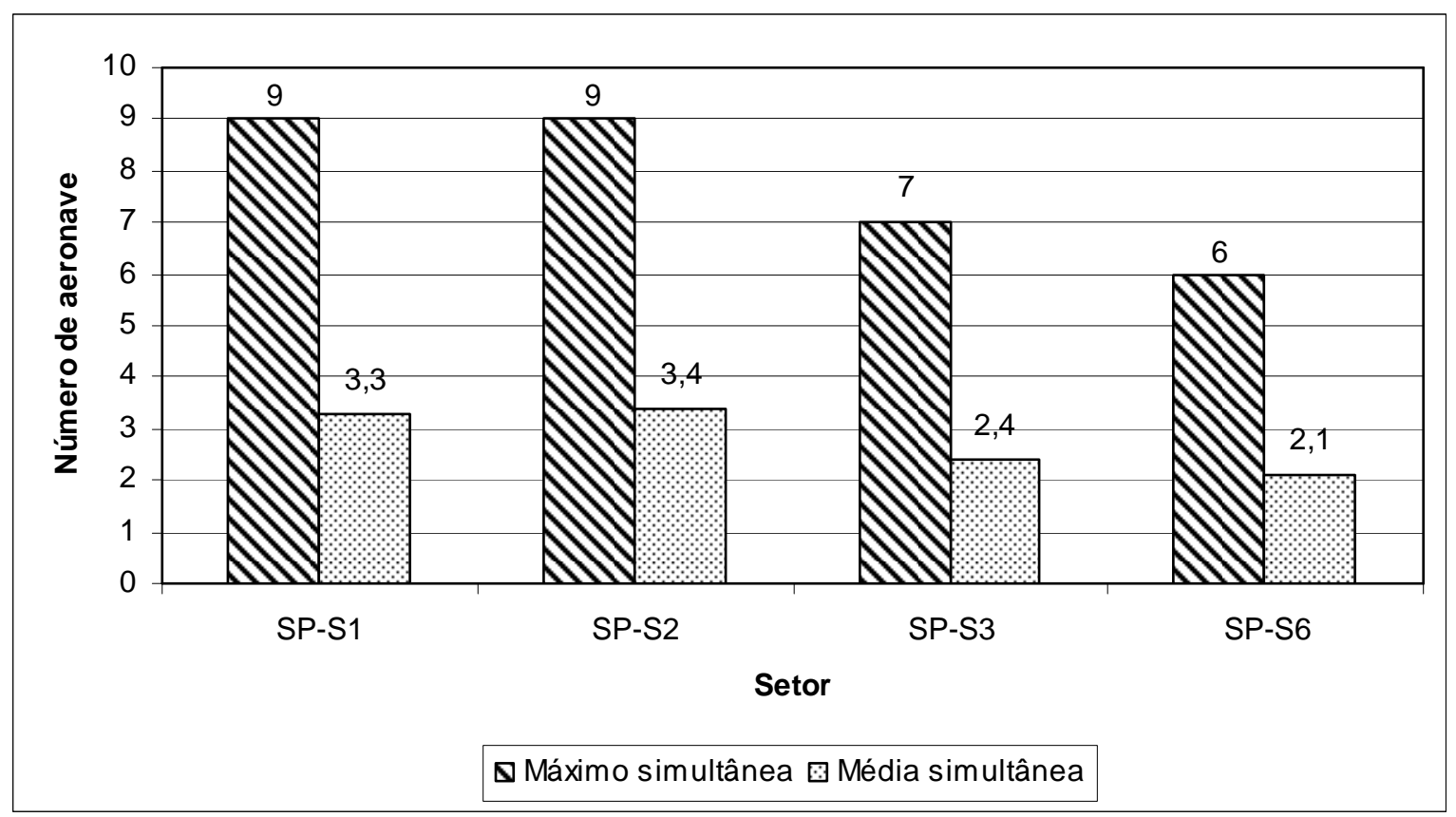

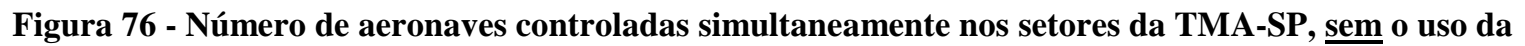
RDL, em 30/08/2006. 


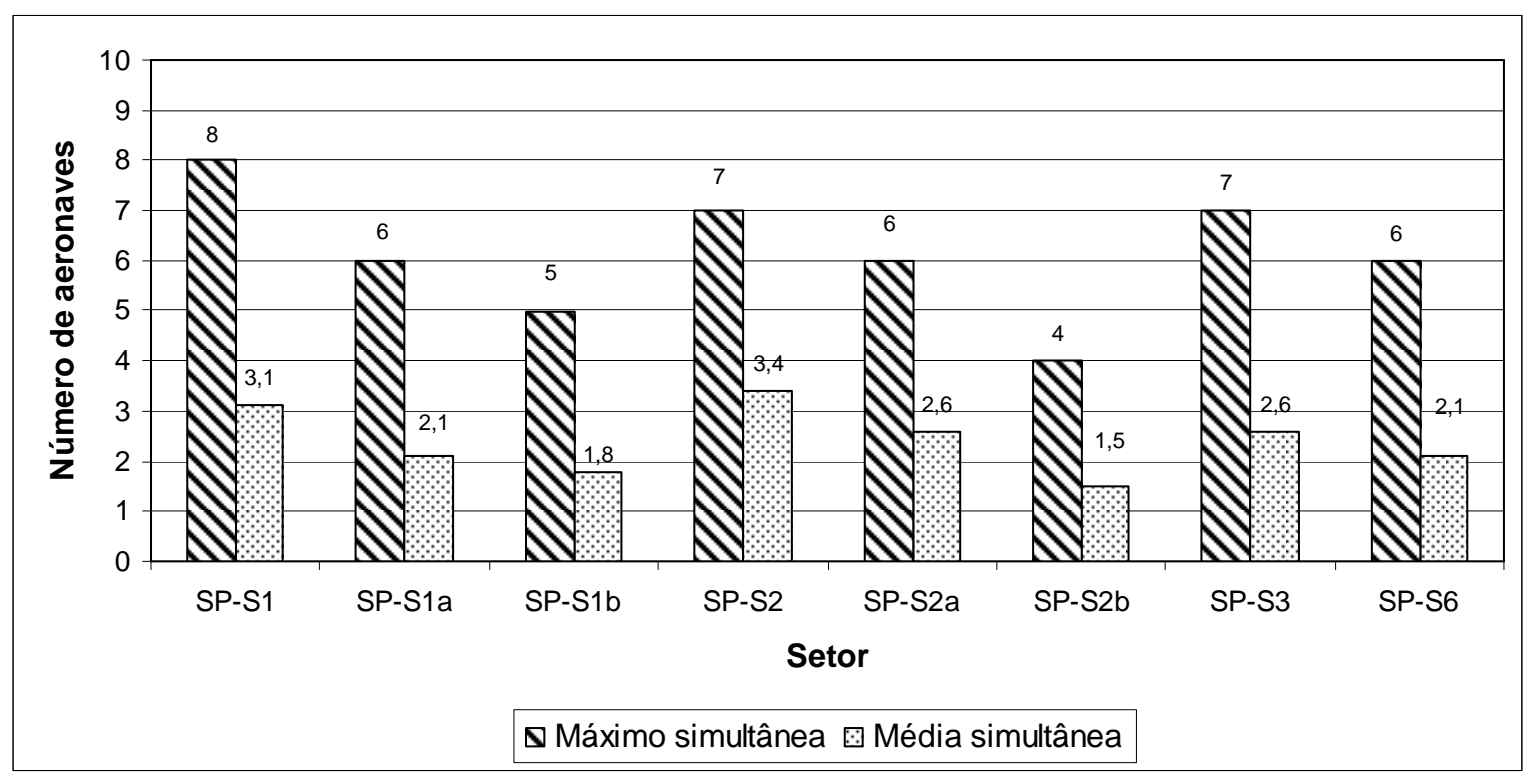

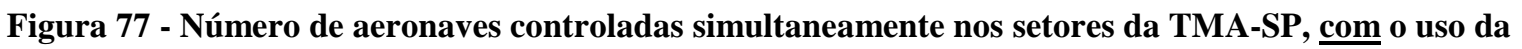
RDL, em 30/08/2006.

Para os setores que não sofreram a re-configuração devido a RDL (setores 3 e 6), a média e o número máximo de aeronaves controladas simultaneamente quase não tiveram variação. Os setores 1 e 2 tiveram 9 aeronaves controladas simultaneamente cada um na simulação sem o uso da RDL. Este valor ficou acima do valor nominal previsto segundo (DECEA, 2007). Na simulação com o uso da RDL, passaram a ter no máximo 8 e 7 aeronaves controladas simultaneamente, respectivamente, valor que está dentro do previsto em (DECEA, 2007). A análise do número de aeronaves controladas simultaneamente não foi realizada para os setores 0, 4 e 5 pelos mesmos motivos descritos no item 5.2.2.

\subsection{Estudo de Caso 2: Tráfego Futuro com Crescimento no Número de Movimentações de Aeronaves}

Este estudo de caso pretende investigar como a carga de trabalho dos controladores de tráfego aéreo se comporta, considerando o crescimento esperado para o número de movimentos (pouso e decolagem), na TMA-SP, para o ano de 2015. Para tanto, foi solicitado aos responsáveis pelo APP-SP um dia com o fluxo de aeronaves típico na TMA-SP. O dia concedido por este órgão foi 04/09/2006. Como no estudo de caso 1 , foi aplicado o processo de pré-simulação, que inclui a filtragem de vôos, a normalização de tipos de aeronaves e a alocação de vôos nas rotas. A Figura 78 ilustra o número de vôos, por hora, contabilizados depois do tratamento dos dados. 


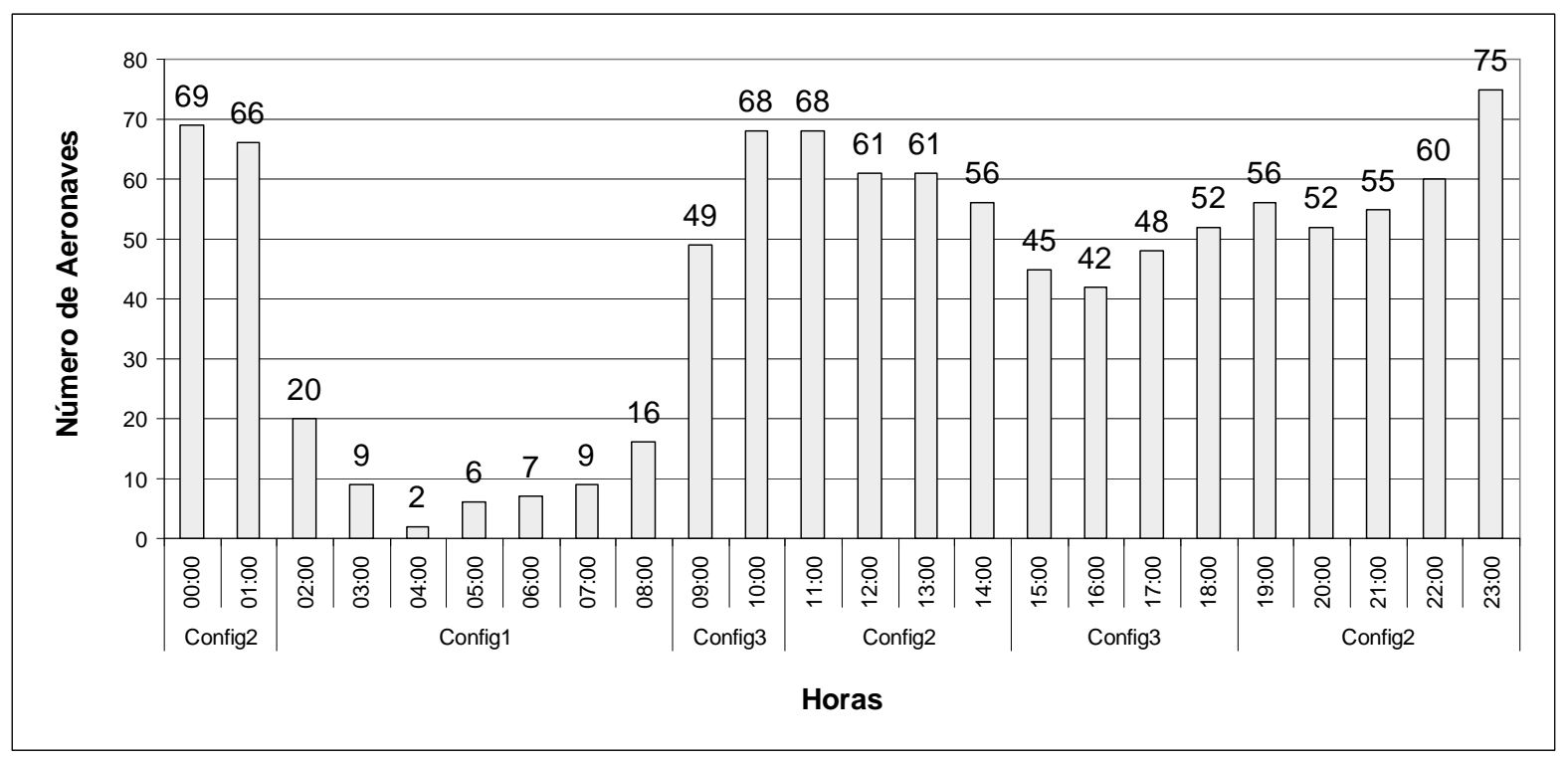

Figura 78 - Movimento de aeronaves (vôos IFR) na TMA-SP, em 04/09/2006.

Como este estudo de caso busca projetar o número de pouso e decolagem na TMA-SP para uma data futura, é necessário ter uma taxa de crescimento esperado para a TMA-SP. Segundo o IAC (2005b) o crescimento esperado entre 2004 e 2025 para o número de pouso e decolagem na aviação nacional, considerando o mercado regular, é expresso na Tabela 5.

Tabela 5 - Aeronaves de passageiros: taxas médias de crescimento anual (\%) para o mercado regular (IAC, 2005b).

\begin{tabular}{|c|c|c|c|c|c|c|c|c|}
\hline & \multicolumn{4}{|c|}{ Doméstico } & \multicolumn{4}{|c|}{ Internacional } \\
\hline Região & $\begin{array}{l}2004- \\
2010\end{array}$ & $\begin{array}{l}2010- \\
2015\end{array}$ & $\begin{array}{l}2015- \\
2025\end{array}$ & $\begin{array}{l}2004- \\
2025\end{array}$ & $\begin{array}{l}2004- \\
2010\end{array}$ & $\begin{array}{l}2010- \\
2015\end{array}$ & $\begin{array}{l}2015- \\
2025\end{array}$ & $\begin{array}{l}2004- \\
2025\end{array}$ \\
\hline Norte & 8,11 & 4,17 & 5,23 & 5,79 & 6,80 & 3,74 & 2,96 & 4,23 \\
\hline Nordeste & 6,54 & 5,46 & 6,02 & 6,03 & 7,26 & 4,07 & 3,89 & 4,89 \\
\hline Sudeste & 8,40 & 4,94 & 5,78 & 6,32 & 7,17 & 4,41 & 4,14 & 5,06 \\
\hline Sul & 8,70 & 5,40 & 6,13 & 6,68 & 5,59 & 4,03 & 3,96 & 4,44 \\
\hline Centro-Oeste & 10,13 & 5,22 & 6,03 & 6,99 & 6,19 & 4,04 & 2,12 & 3,72 \\
\hline Brasil & 8,33 & 5,06 & 5,86 & 6,37 & 7,00 & 4,33 & 4,04 & 4,95 \\
\hline
\end{tabular}

Segundo a Tabela 5, o mercado regular de aviação brasileira, para os vôos nacionais e internacionais, crescerá a uma taxa de 6,37\% e 4,95\% ao ano, repetitivamente, no período de 2004 a 2025. No caso específico da região Sudeste do Brasil, em relação ao mercado regular 
da aviação brasileira, o número de pousos e decolagens no período de 2004 a 2025 será de $6,32 \%$ e $5,06 \%$ ao ano, para os vôos nacional e internacional, respectivamente.

Em IAC (2005a) é detalhada a tendência de crescimento, tanto do número de movimento, pouso e decolagem, quanto do número de passageiros esperado até 2025 para cada aeroporto brasileiro. Consolidado os aeroportos da TMA-SP (SBKP, SBGR, SBSP e SBMT) foi estimado o crescimento esperado até 2025, específico para a TMA-SP. Maiores detalhes são apresentados na Tabela 6.

Tabela 6 - Crescimento esperado até 2025 do número de pouso e decolagem nos aeroportos da TMA-SP (IAC, 2005a).

\begin{tabular}{|c|c|}
\hline \multicolumn{2}{|c|}{ Número de Movimentos na TMA-SP em 2004} \\
\hline SBSP & 217.782 \\
\hline SBGR & 149.497 \\
\hline SBKP & 24.576 \\
\hline SBMT & 81.110 \\
\hline Total & $\mathbf{4 7 2 . 9 6 5}$ \\
\hline
\end{tabular}

\begin{tabular}{|c|c|c|c|}
\hline \multicolumn{4}{|c|}{ Projeção de crescimento em SBKP } \\
\hline & Pessimista & Médio & Otimista \\
\hline 2010 & 34.635 & 43.165 & 53.091 \\
\hline 2015 & 43.276 & 54.433 & 67.810 \\
\hline 2025 & 70.733 & 90.085 & 114.566 \\
\hline
\end{tabular}

\begin{tabular}{|c|c|c|c|}
\hline \multicolumn{4}{|c|}{ Projeção de crescimento em SBSP } \\
\hline & Pessimista & Médio & Otimista \\
\hline 2010 & 270.781 & 333.237 & 408.636 \\
\hline 2015 & 343.237 & 425.618 & 527.932 \\
\hline 2025 & 583.754 & 726.983 & 918.231 \\
\hline
\end{tabular}

\begin{tabular}{|c|c|c|c|}
\hline \multicolumn{4}{|c|}{ Projeção de crescimento em SBMT } \\
\hline & Pessimista & Médio & Otimista \\
\hline 2010 & 88.618 & 125.759 & 177.681 \\
\hline 2015 & 98.425 & 146.764 & 217.912 \\
\hline 2025 & 139.422 & 233.067 & 390.122 \\
\hline
\end{tabular}

\begin{tabular}{|c|c|c|c|}
\hline \multicolumn{4}{|c|}{ Projeção de crescimento em SBGR } \\
\hline & Pessimista & Médio & Otimista \\
\hline 2010 & 203.788 & 245.616 & 293.402 \\
\hline 2015 & 258.351 & 313.207 & 376.863 \\
\hline 2025 & 421.940 & 516.689 & 631.442 \\
\hline
\end{tabular}

\begin{tabular}{|c|c|c|c|}
\hline \multicolumn{4}{|c|}{ Projeção de crescimento na TMA-SP } \\
\hline & Pessimista & Médio & Otimista \\
\hline 2010 & 597.822 & 747.777 & 932.810 \\
\hline 2015 & 743.289 & 940.022 & 1.190 .517 \\
\hline 2025 & 1.215 .849 & 1.566 .824 & 2.054 .361 \\
\hline
\end{tabular}

Segundo a Tabela 6, o número de movimentos nos aeroporto da TMA-SP foi de 472.965 pousos e decolagens no ano de 2004. Para cada um dos quadro aeroportos da TMA-SP existe um crescimento otimista, pessimista e médio para o número de pousos e decolagem previsto 
até 2025. Somando, respectivamente, os crescimentos otimista, pessimista e médio esperado até 2025 para os aeroportos SBKP, SBGR, SBSP e SBMT, chega-se aos crescimentos otimista, pessimista e médio esperados para TMA-SP até 2025, como ilustrado na Tabela 6. De posse desses dados, elaborou-se o gráfico ilustrado da Figura 79 que apresenta a projeção da evolução do número de movimentos (pouso e decolagem) na TMA-SP, de 2004 a 2025.

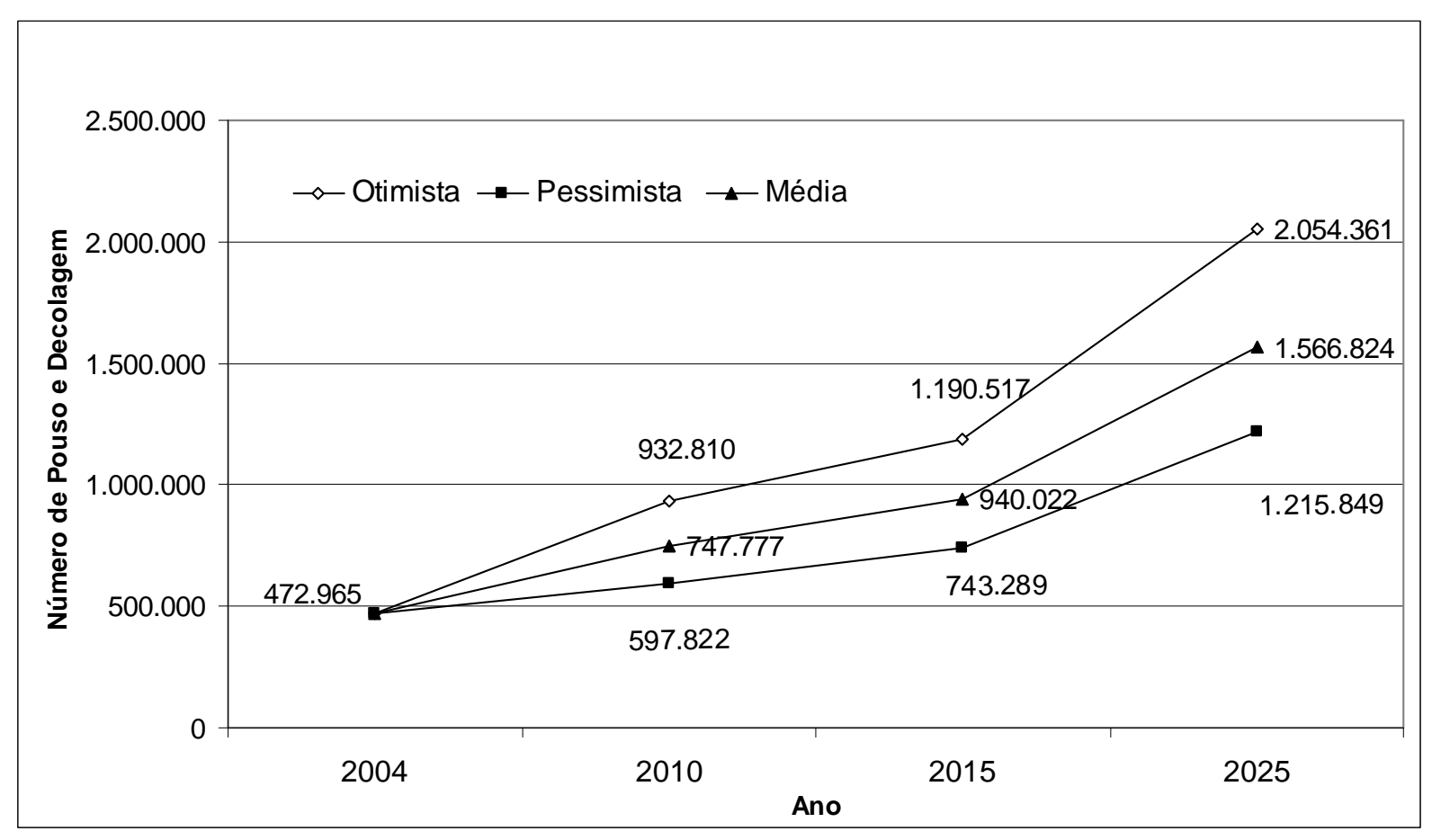

Figura 79 - Projeção da evolução do número de movimentos (pouso e decolagem) em SBKP, SBGR, SBSP e SBMT, de 2004 a 2025.

Conforme ilustrado no gráfico da Figura 79, o número de pousos e decolagens na TMA-SP será em média, até 2025, três vezes maior que em 2004. No caso da análise mais otimista, este número de movimentos será em torno de quatro vezes maior em 2025, se comparado com 2004. Olhando a análise mais pessimista, este número reduz-se para menos que três vezes o número de pouso e decolagem na TMA-SP, se comparado ao número de 2004.

A partir da consolidação do crescimento esperado até 2025, referentes aos números de pousos e decolagens expressos na Tabela 6, construiu-se a taxa de crescimento anual esperado para a TMA-SP até 2025, considerando os crescimentos otimista, médio e pessimista, o que é ilustrado na Tabela 7. 
Tabela 7 - Taxa média de crescimento anual na TMA-SP (\%).

\begin{tabular}{|c|c|c|c|}
\hline \multicolumn{4}{|c|}{ Crescimento Médio por ano na TMA-SP } \\
\hline & Pessimista & Médio & Otimista \\
\hline $2004-2010$ & 3,98 & 7,93 & 11,98 \\
\hline $2004-2015$ & 4,20 & 6,44 & 8,75 \\
\hline $2004-2025$ & 4,60 & 5,87 & 7,24 \\
\hline
\end{tabular}

A taxa de crescimento esperado para o sudeste brasileiro, de 2004 a 2025, é de 6,32\% ao ano, segundo a Tabela 5, e a taxa média calculada especificamente para a TMA-SP, segundo a Tabela 7, é de 5,87\% ao ano. O número de movimentos na TMA-SP em média crescerá a uma taxa menor que o esperado para toda a região Sudeste do Brasil. Contudo, levando em consideração a previsão otimista (de maior crescimento), o crescimento na TMA-SP seria maior que o da previsão específica da região Sudeste.

Considerado a taxa média de crescimento na TMA-SP entre os anos de 2004 e 2025, o número de movimentos neste espaço aéreo será multiplicado por 2,95, quase o triplo do atual. Os 1052 vôos de 04/09/2006 passarão para 3103, em média, em 2025. Isso representa, em média, aproximadamente 3 vôos por minuto na TMA-SP, ou um vôo por minuto em cada um dos aeroportos (considerando o funcionamento dos aeroportos da 06:00 as 23:00 para SBGR, SBSP e SBKP). Se for considerado o cenário otimista, essa taxa sobe para aproximadamente 4 vôos por minuto na TMA-SP.

Buscando um estudo não tão voltado para um tempo distante, como no caso 2025 , e sem considerar um número de pousos e decolagens muito superior ao atual, neste estudo de caso decidiu-se considerar o crescimento médio esperado entre 2004 e 2015 de 6,44\% ao ano para a TMA-SP (vide Tabela 7). Este crescimento de 6,44\% representa um aumento de 75,36\% no tráfego aéreo na TMA-SP entre 2006 e 2015.

Com o crescimento médio de 6,44\% ao ano, os 1052 vôos em 04/09/2006 passarão para 1845 vôos em 2015. A Figura 80 ilustra o volume de aeronaves, por hora, em 04/09/2006, e o volume esperado para 2015. 


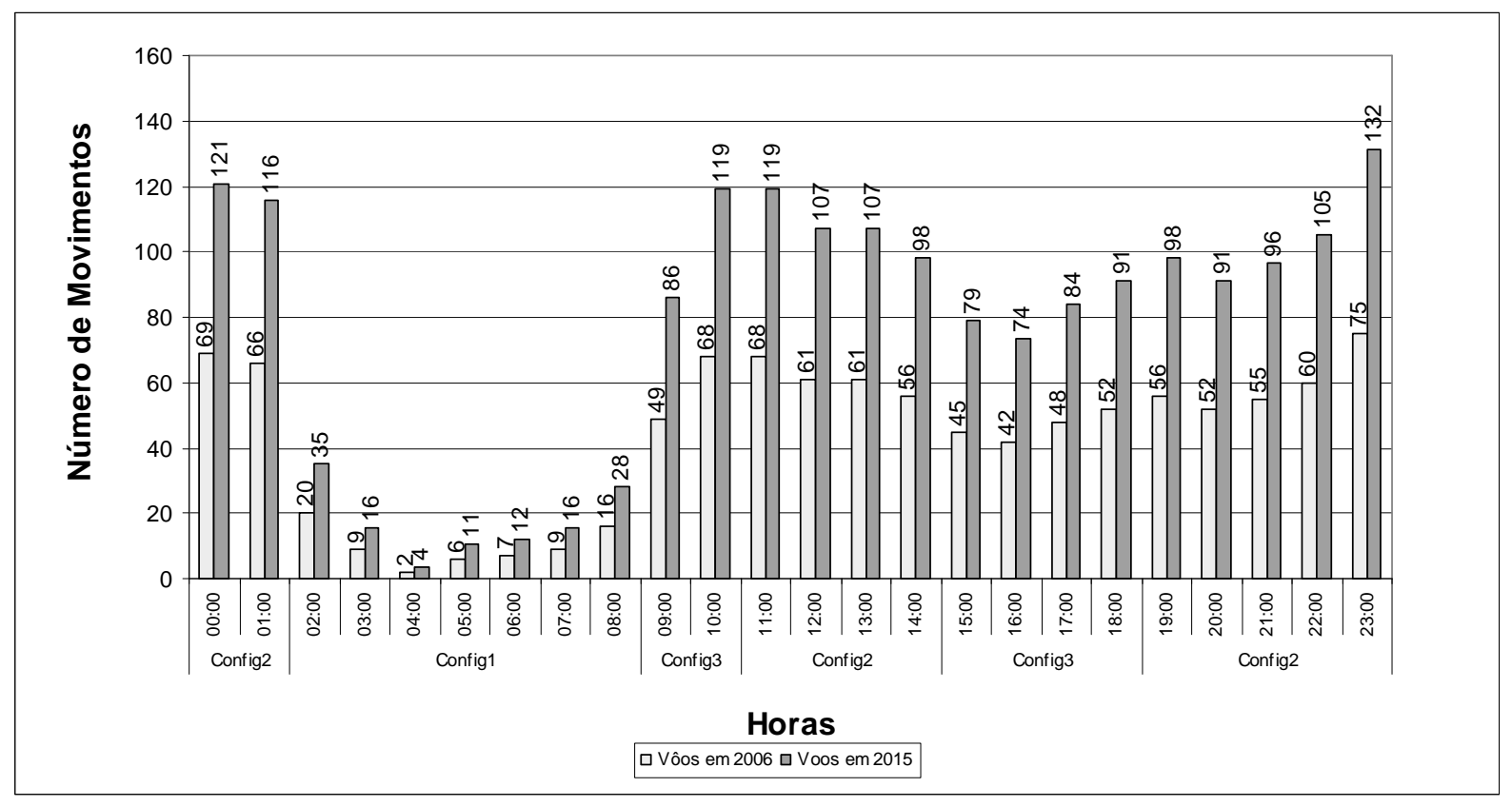

Figura 80 - Movimentos de aeronaves na TMA-SP, em 04/09/2006, e a projeção para 2015.

Uma premissa para criar um cenário com crescimento de $75,36 \%$ foi não fazer um aumento linear dos vôos durante o dia, mas um aumento considerando a porcentagem do tráfego por hora, pois com um aumento linear não existe a acentuação dos momentos de baixa e alta demanda de aeronaves. A Tabela 8 ilustra o número de vôos, pouso e decolagem, por hora, e qual a porcentagem deste número no volume total do dia. Para cada hora foi multiplicado o resultado dessa porcentagem (terceira coluna da tabela) pela quantidade de movimentos esperado em 2015 (1845 movimentos). O resultado é apresentado na última coluna da Tabela 8 e representa o número de movimentos esperado, por hora, em 2015, considerando o aumento de $75,36 \%$.

Na montagem do tráfego de 2015, inicialmente todos os 1052 vôos tiveram sua origem, destino e horário duplicados. Isso foi adotado porque, segundo a estatística apresentada em 2015, o tráfego aéreo "quase dobra" em relação a 2006. Neste modelo foi levada em conta também a simplicidade para atingir o crescimento esperado para 2015.

Posteriormente, para cada hora, foi retirado aleatoriamente vôos até que o número de vôos por hora fosse igual ao esperado, segundo a Tabela 8. Por exemplo, das 15:00 as 16:00, tem-se 45 vôos em 04/09/2006. Todos estes vôos foram duplicados, passando para 90 vôos. Foram retirados, aleatoriamente, vôos deste horário até que o número de vôos chegasse a 79. 
Tabela 8 - Projeção do número de movimentos na TMA-SP para 2015.

\begin{tabular}{|c|c|c|c|}
\hline Hora & Vôos em 2006 & Porcentagem & Vôos em 2015 \\
\hline 00:00 & 69 & $6,56 \%$ & 121 \\
\hline 01:00 & 66 & $6,27 \%$ & 116 \\
\hline 02:00 & 20 & $1,90 \%$ & 35 \\
\hline 03:00 & 9 & $0,86 \%$ & 16 \\
\hline 04:00 & 2 & $0,19 \%$ & 4 \\
\hline 05:00 & 6 & $0,57 \%$ & 11 \\
\hline 06:00 & 7 & $0,67 \%$ & 12 \\
\hline 07:00 & 9 & $0,86 \%$ & 16 \\
\hline 08:00 & 16 & $1,52 \%$ & 28 \\
\hline 09:00 & 49 & $4,66 \%$ & 86 \\
\hline $10: 00$ & 68 & $6,46 \%$ & 119 \\
\hline $11: 00$ & 68 & $6,46 \%$ & 119 \\
\hline $12: 00$ & 61 & $5,80 \%$ & 107 \\
\hline 13:00 & 61 & $5,80 \%$ & 107 \\
\hline $14: 00$ & 56 & $5,32 \%$ & 98 \\
\hline $15: 00$ & 45 & $4,28 \%$ & 79 \\
\hline $16: 00$ & 42 & $3,99 \%$ & 74 \\
\hline 17:00 & 48 & $4,56 \%$ & 84 \\
\hline 18:00 & 52 & $4,94 \%$ & 91 \\
\hline 19:00 & 56 & $5,32 \%$ & 98 \\
\hline 20:00 & 52 & $4,94 \%$ & 91 \\
\hline $21: 00$ & 55 & $5,23 \%$ & 96 \\
\hline 22:00 & 60 & $5,70 \%$ & 105 \\
\hline 23:00 & 75 & $7,13 \%$ & 132 \\
\hline Total & 1052 & $100,00 \%$ & 1845 \\
\hline
\end{tabular}

Como atualmente não existem decolagem e pouso simultâneos nos aeroportos da TMA-SP, os horários dos vôos duplicados foram corrigidos, buscando-se um maior espaçamento entre o horário do vôo original e o horário do vôo duplicado, de forma que esses horários ficassem sempre contidos no intervalo de uma hora estabelecido para os vôos.

O objetivo da busca do maior espaçamento entre o horário do vôo original e do vôo duplicado é ter um número de vôos espalhados durante cada intervalo de tempo de uma hora, evitandose ter uma concentração de aeronaves decolando ou pousando uma em seguida da outra. Outra regra observada no momento dos ajustes dos horários foi ter, no mínimo, dois minutos decorridos entre pousos ou entre decolagens consecutivas, como o proposto em (AIC 100-12, 2006). 
A análise dos resultados deste estudo de caso está dividida em duas partes. A primeira aborda o cenário atual e o proposto para 2015, sem o uso da RDL, e a segunda aborda o cenário futuro com e sem o uso da RDL, para o tráfego esperado para 2015. Todas as soluções de contorno descritas no Estudo de Caso 1, referentes à TMA-SP, e que não puderam ser implementadas no software de simulação RAMS Plus, foram adotadas nos dados que serão apresentados a seguir.

\subsubsection{Comparativo do Cenário Atual com o Cenário Esperado para 2015}

A Figura 81 representa o crescimento esperado para 2015 da soma dos pesos das tarefas realizadas pelos controladores de tráfego aéreo, organizado por setor. A soma dos pesos das tarefas cresceu praticamente na mesma taxa de crescimento do número de movimentos do tráfego dos aeroportos da TMA-SP, ou seja, aproximadamente 75\% na média. Gráficos detalhados desse crescimento encontram-se no Anexo II.

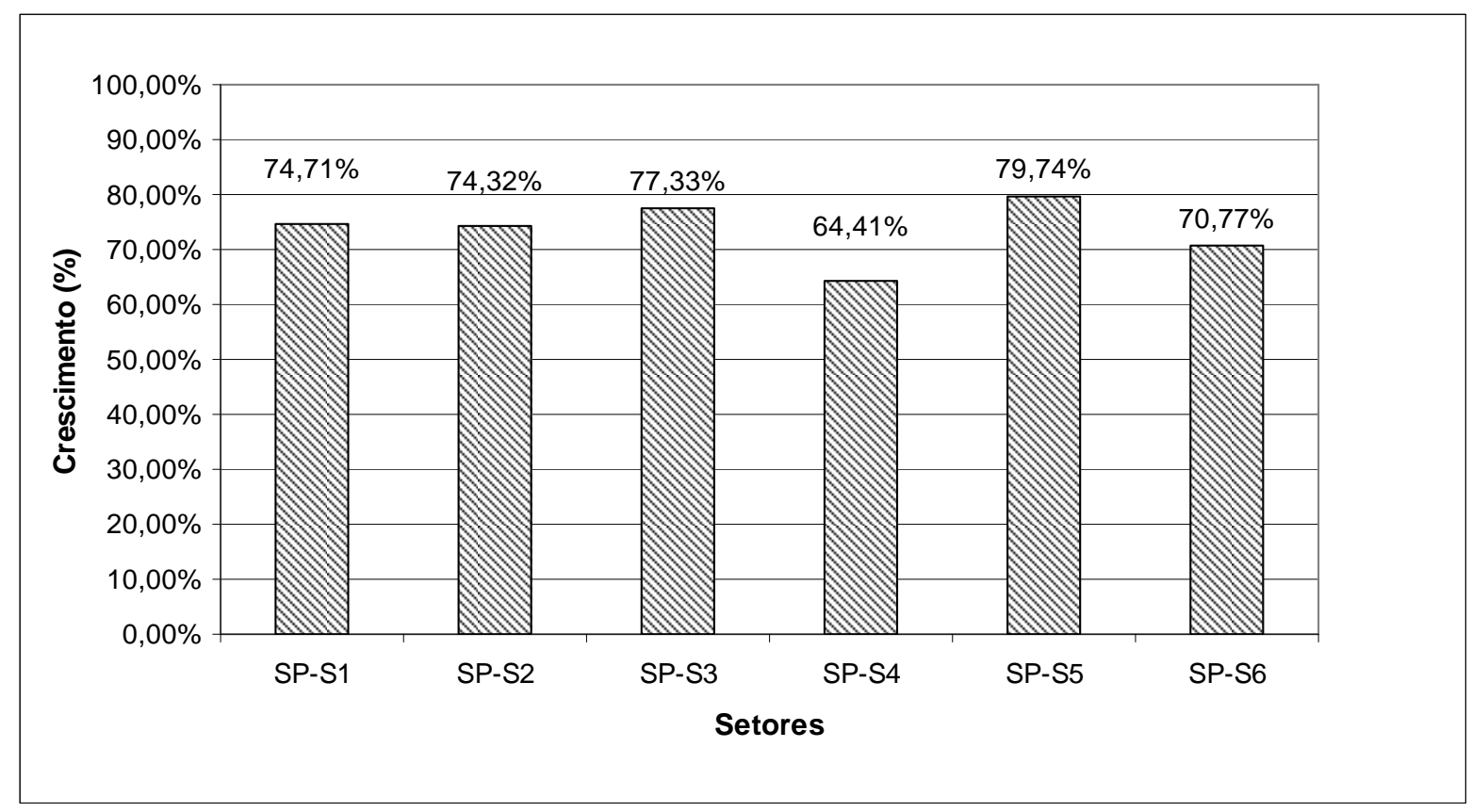

Figura 81 - Porcentagem de crescimento da soma dos pesos das tarefas realizadas pelo controlador de tráfego aéreo, por setor, sem o uso da RDL, esperado para 2015.

Em contrapartida, o crescimento esperado para 2015 do número de conflitos em potencial detectados por setores não apresentou a mesma taxa de crescimento da soma dos pesos das tarefas realizadas pelos controladores, como ilustrado na Figura 82. 


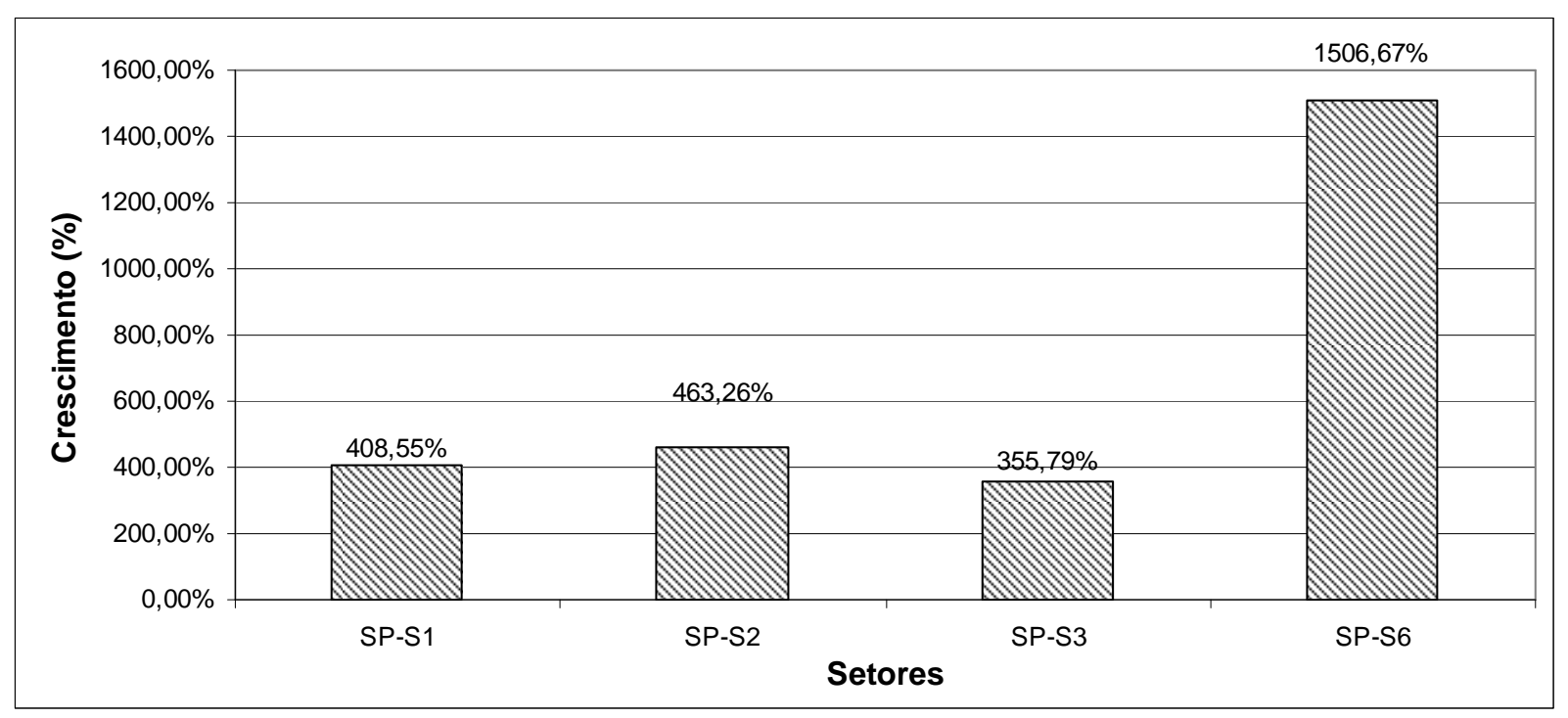

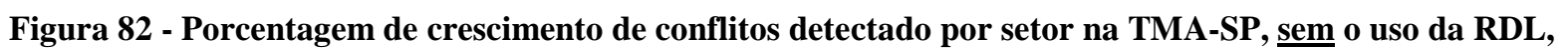
esperado para 2015.

O crescimento dos números de conflitos detectados apresentou uma taxa de crescimento entre $355 \%$ e $463 \%$ para os setores 1,2 e 3 , chegando a $1.506 \%$ no setor 6 , com relação ao período entre 2006 e 2015. No caso do setor 6, esse crescimento foi tão expressivo porque o número de conflitos em potencial detectado em 2006 (30 conflitos), foi muito baixo em relação ao detectado em 2015 (482 conflitos), gerando este crescimento elevado de $1.506 \%$ em relação aos setores 1, 2 e 3. Em relação aos valores absolutos, o número de conflitos em potencial detectado no setor 6 em 2006 e 2015 ficou menor em comparação com os números absolutos de conflitos em potencial detectados nos setores 1, 2 e 3. Maiores detalhes podem ser encontrados no Anexo II.

Analisando os gráficos apresentados na Figura 81 e na Figura 82, surge o seguinte questionamento: por quê a taxa de crescimento da soma dos pesos das tarefas, presente na Figura 81, não acompanhou a taxa de crescimento do número de conflitos em potencial, visualizada na Figura 82, já que os controladores de tráfego aéreo têm que realizar tarefas para resolver estes conflitos?

A resposta a essa pergunta encontra-se na seção 4.3 (item d - Resolução de conflitos utilizando técnicas de inteligência artificial). O software de simulação RAMS Plus disponibiliza um módulo de resolução automática de conflitos com a intervenção do controlador de tráfego aéreo. Contudo, durante as simulações realizadas nesta investigação científica, foi desativado o módulo de resolução de conflito do RAMS Plus. Quando este módulo era ativado, a simulação "travava", pois o software entrava em um laço (loop) 
infinito. Isso pode ter ocorrido devido ao grande volume de aeronaves utilizado nas simulações.

Outro ponto de análise é que o número de aeronaves controladas simultaneamente influencia diretamente na carga de trabalho dos controladores de tráfego aéreo. Quanto maior o número de aeronaves controladas simultaneamente, maior será a atenção necessária dos controladores de tráfego aéreo e, portanto, maior deverá ser a sua carga de trabalho.

Segundo DECEA (2007) o número máximo de aeronaves suportadas simultaneamente nos setores 1,2 e 3 é de 8 aeronaves. Na simulação sem o uso da RDL, para o tráfego de 04/09/2006, o número de aeronaves controladas simultaneamente pelos controladores de tráfego aéreo foi maior que o limite estipulado pelo DECEA (2007) para os setores 1 e 2 (a figura mostra 9 aeronaves), como ilustrado no gráfico da Figura 83. Este número ficou ainda maior na simulação utilizando o tráfego esperado para 2015, chegando a 22 aeronaves controladas simultaneamente no setor 2 .

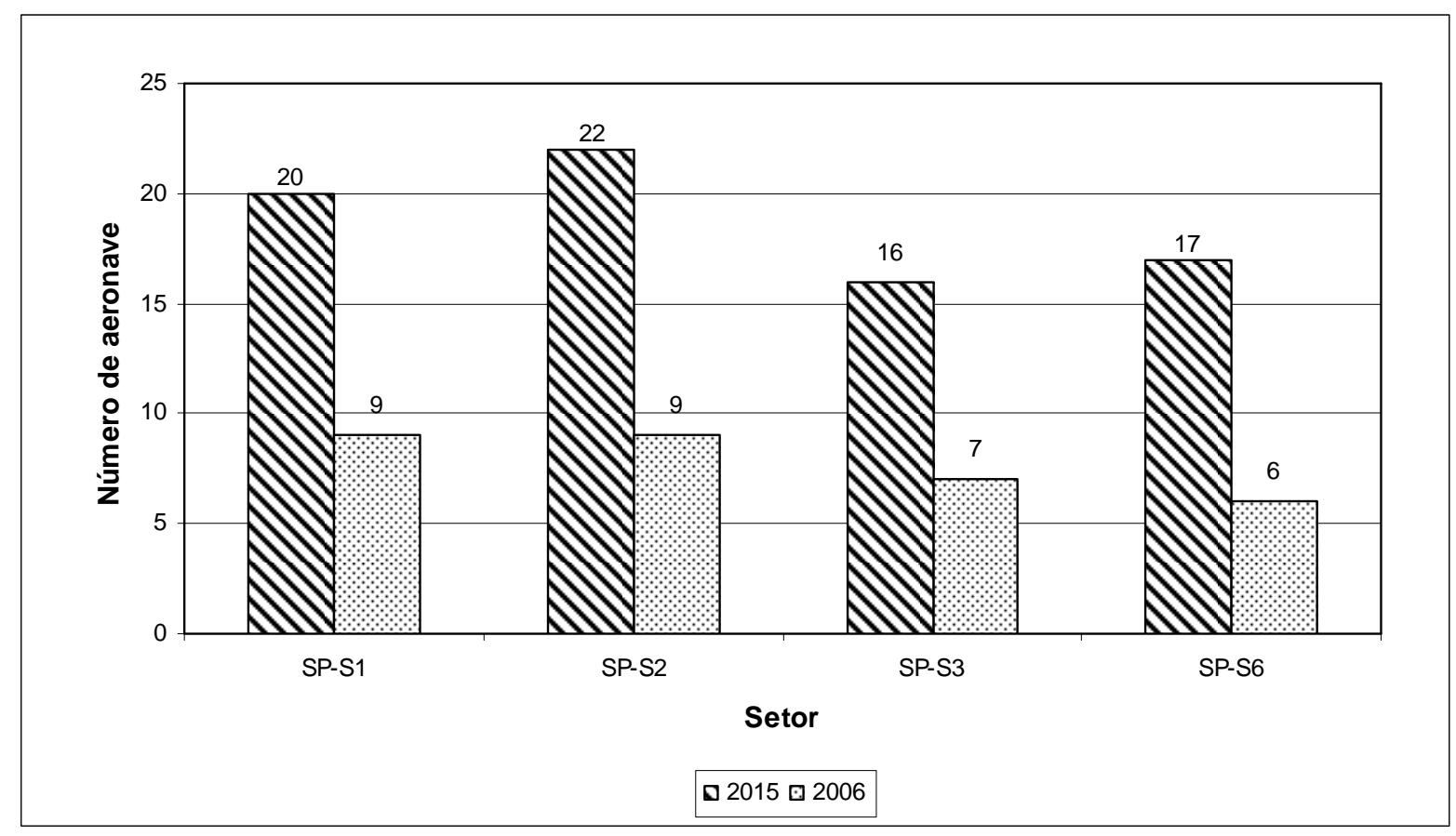

Figura 83 - Número de aeronaves controladas simultaneamente nos setores da TMA-SP, $\underline{\text { sem }}$ o uso da DRL, em 04/09/2006, e o número esperado para 2015.

Como conclusão, a soma dos pesos das tarefas realizadas pelos controladores de tráfego aéreo cresceu na mesma proporção que o crescimento dos números de pousos e decolagens na TMA-SP. Os números de conflitos, porém, apresentaram um aumento mais significativo em relação ao crescimento da carga de trabalho do controlador de tráfego aéreo. Já o número de 
aeronaves controladas simultaneamente quase que triplicou o limite estabelecido pelo DECEA (DECEA, 2007) na projeção para 2015.

\subsubsection{Análise do Cenário Esperado para 2015}

Esta segunda parte da análise deste Estudo de Caso consiste em apresentar os resultados das simulações feitas com e sem o uso da RDL, utilizando um tráfego esperado para 2015. Como no Estudo de Caso 1, a apresentação e análise dos resultados é dividida em quatro partes, a saber:

- Análise da Carga de Trabalho do Controlador de Tráfego Aéreo;

- Análise do Número de Conflitos em Potencial;

- Análise da Função Complexidade; e

- Análise do Número de Aeronaves Controladas Simultaneamente pelo Controlador de Tráfego Aéreo.

\subsubsection{Análise da Carga de Trabalho do Controlador de Tráfego Aéreo}

A Figura 84 e a Figura 85 ilustram os gráficos das somas dos pesos das tarefas realizadas pelos controladores de tráfego aéreo, organizadas por setor, com e sem o uso da RDL. Com o agrupamento e criação de novos setores utilizando a RDL, a carga de trabalho foi distribuída entre esses novos setores. Segundo a Figura 84 e a Figura 85, o uso da RDL para o tráfego esperado para 2015 proporciona uma carga de trabalho menor para os setores $0,1,2,1 \mathrm{a}, 1 \mathrm{~b}$, $2 \mathrm{a}$ e $2 \mathrm{~b}$ do que a carga de trabalho registrada nos setores 1 e 2 originais sem a RDL.

Como apresentado no Estudo de Caso 1, com exceção do setor 4, os setores que não sofreram re-setorização apresentaram um menor carga de trabalho com o uso da RDL, se comparado com a simulação sem o uso da RDL. 


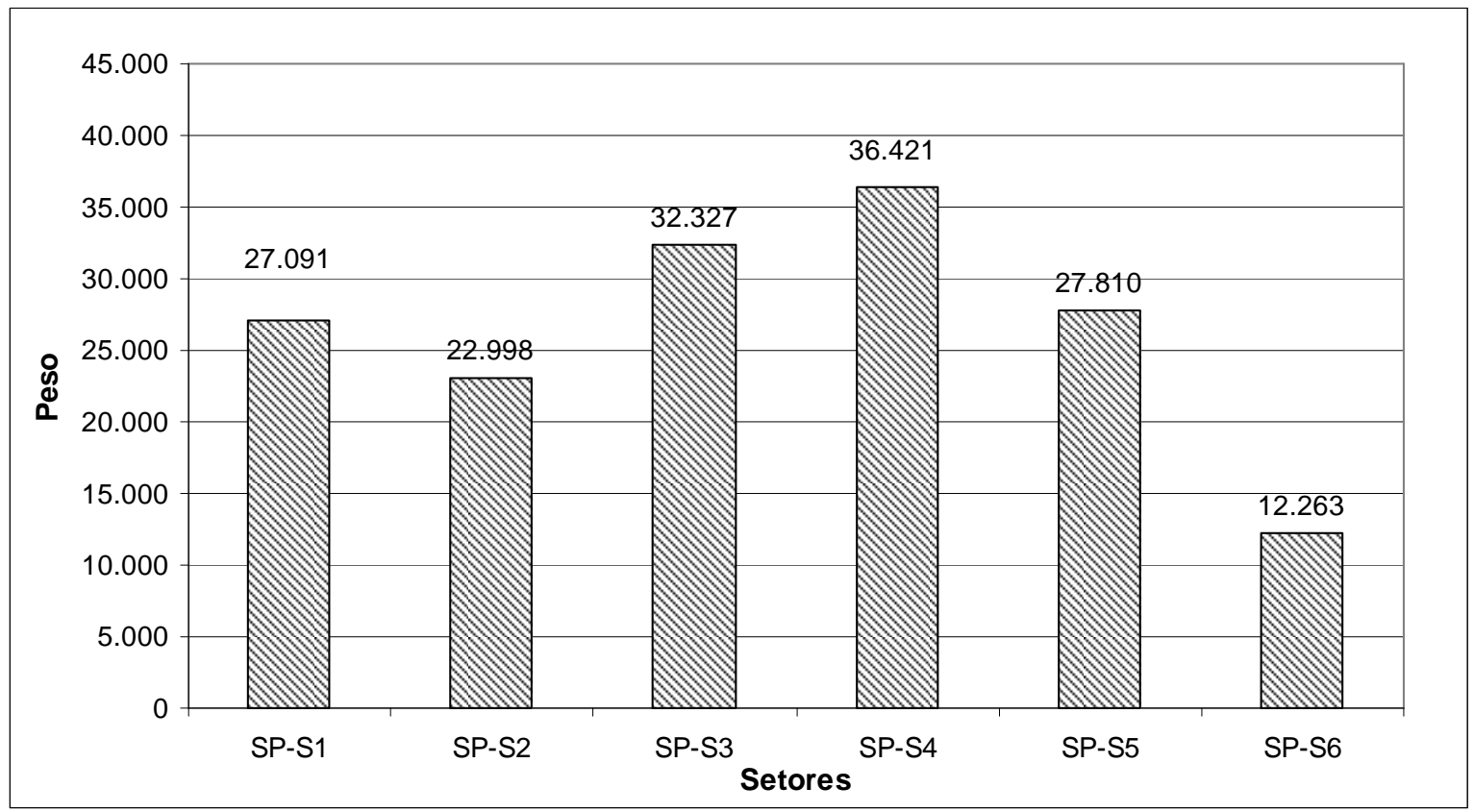

Figura 84 - Soma dos pesos das tarefas realizadas pelos controladores, por setor, $\underline{\text { sem }}$ o uso da RDL, esperado para 2015.

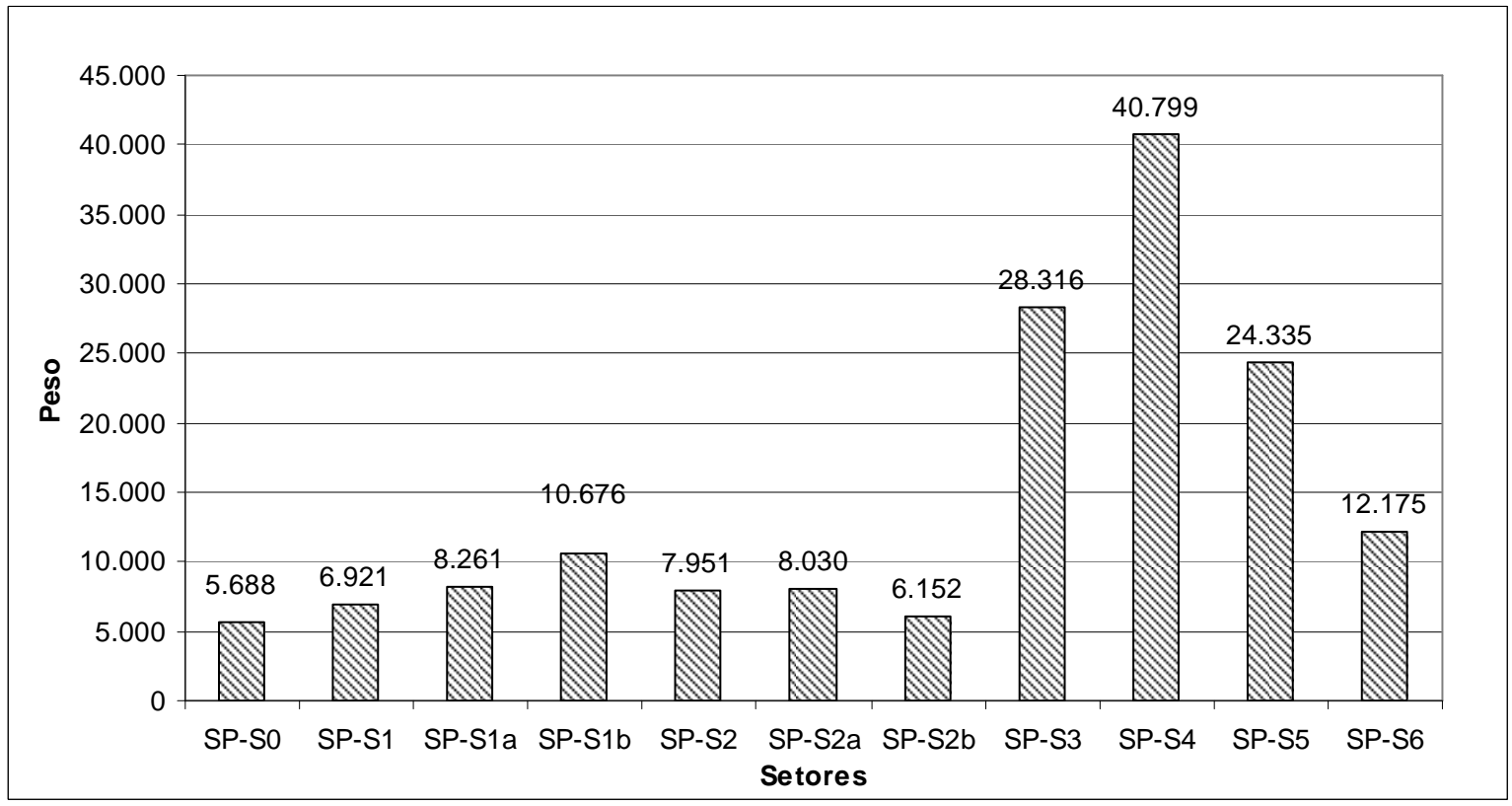

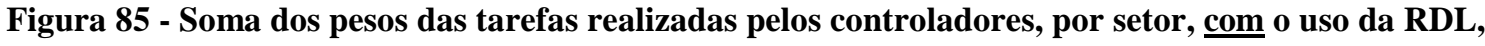
esperado para 2015.

A Figura 86 e a Figura 87 ilustram uma visão mais detalhada das tarefas realizadas pelos controladores de tráfego aéreo. Estes gráficos foram construídos a partir da somatória, por hora, dos pesos das tarefas realizadas pelos controladores dos setores 1 e 2, sem o uso da RDL, e nos setores 1, 1a, 1b e 2, 2a, 2b, com o uso da RDL, durante as simulações computacionais utilizando o tráfego aéreo esperado para 2015. 


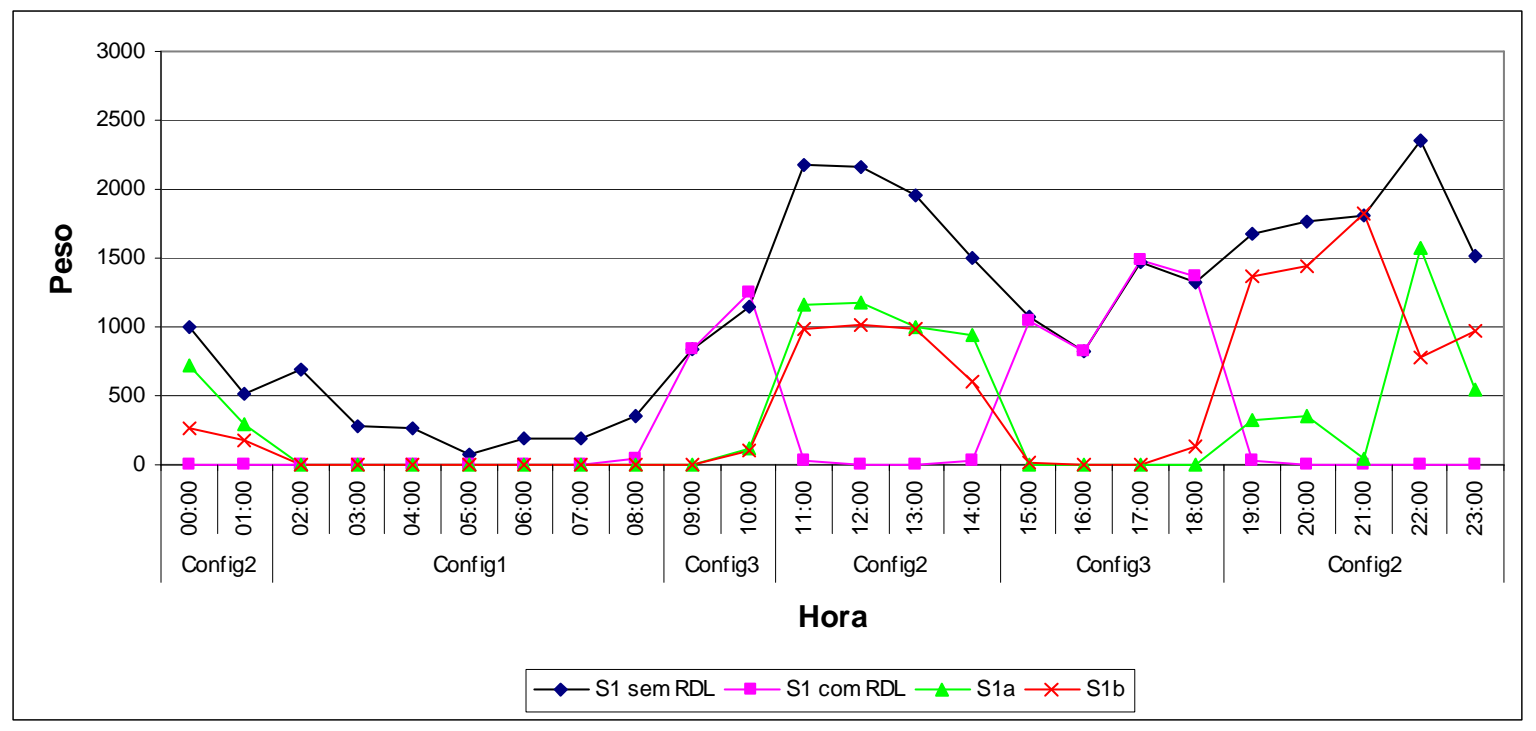

Figura 86 - Soma, por hora, dos pesos das tarefas realizadas pelos controladores nos setores 1, 1a e 1b,

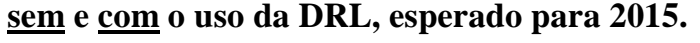

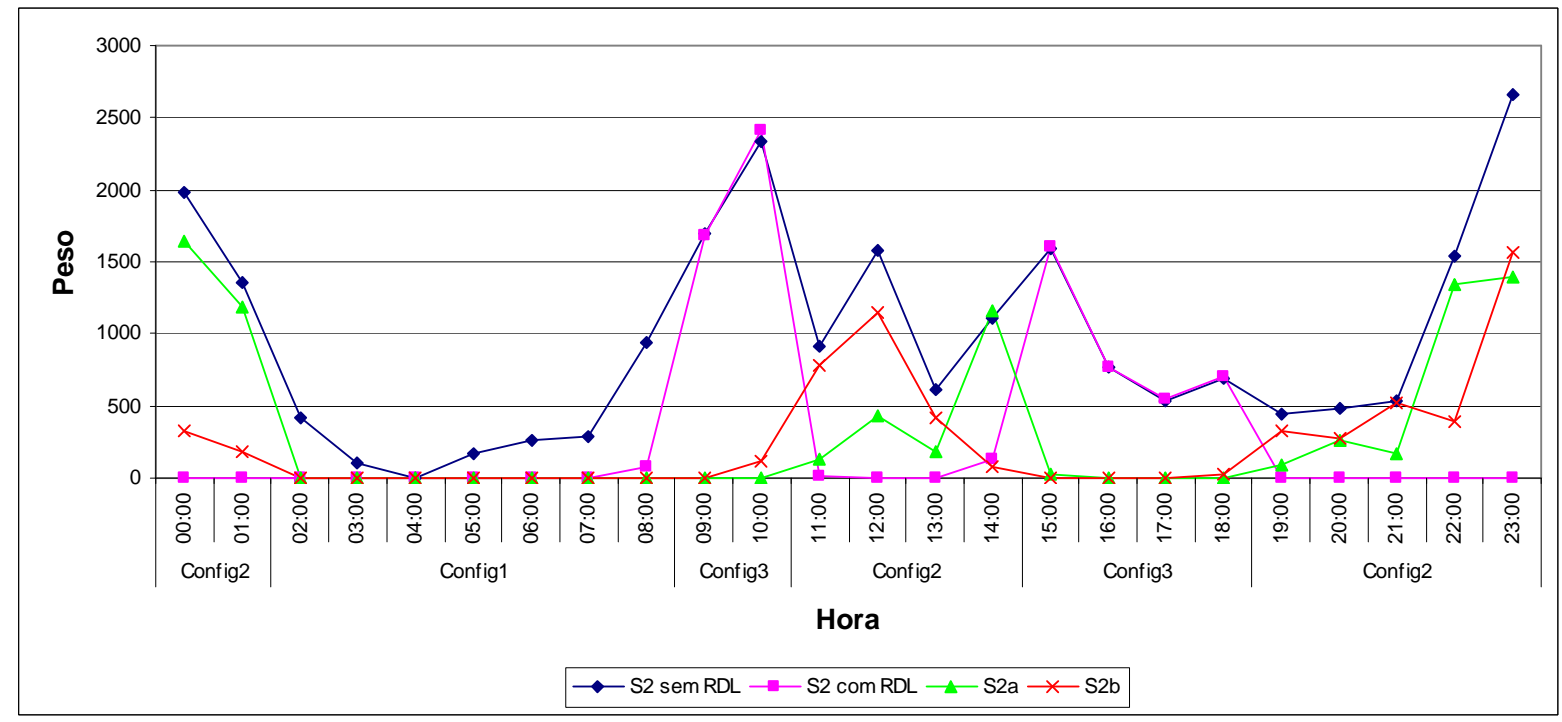

Figura 87 - Soma, por hora, dos pesos das tarefas realizadas pelos controladores nos setores 2, 2a e 2b,

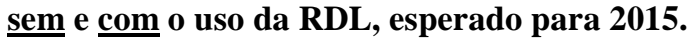

O gráfico ilustrado na Figura 86 representa o mesmo resultado apresentado no estudo de caso 1, com relação à Figura 67. O uso da RDL conseguiu reduzir a carga de trabalho do controlador de tráfego aéreo durante os momentos de pico nos períodos das 11:00 as 14:59 e das 22:00 as 23:59 (configuração 2). Para os períodos em que esteve ativa a configuração 3 (configuração atual da TMA-SP), a soma por hora dos pesos das tarefas (carga de trabalho) dos controladores de tráfego aéreo permaneceu praticamente a mesma, se comparada com a obtida para o mesmo período do setor 1, sem o uso da RDL. 
Na Figura 87, o momento de pico da carga de trabalho dos controladores de tráfego aéreo não coincidiu com o período em que a configuração 2 (divisão do setor 1 em 1a e 1b, e divisão do setor 2 em 2 a e 2 b) esteve ativa. A configuração 2 foi criada justamente para balancear a carga de trabalho dos controladores de tráfego aéreo nos momentos de pico. Dois aspectos podem ser considerados a respeito desse resultado:

a) Nem sempre as configurações construídas segundo uma demanda de aeronaves atende, para todos os tipos de tráfego aéreo, os requisitos para balancear a carga de trabalho dos controladores de tráfego aéreo. Nesta investigação, foram utilizados, para todas as simulações realizadas, o mesmo espaço aéreo, as mesmas configurações do espaço aéreo e os mesmos momentos de chaveamento entre cenários. No Estudo de Caso 1, mais especificamente de acordo com os gráficos ilustrados pelas Figura 67 e Figura 68, este cenário atendeu aos requisitos de balancear a carga de trabalho dos controladores de tráfego aéreo dos setores 1 e 2 . A configuração 2 foi ativada justamente no momento de pico da carga de trabalho dos controladores de tráfego aéreo. No Estudo de Caso 2, para o setor 1, segundo a Figura 86, a configuração 2 também foi ativada justamente no momento de pico da carga de trabalho dos controladores de tráfego aéreo responsáveis pelo setor 1. Contudo, segundo a Figura 87, não ocorreu o mesmo para o setor 2. Apesar de existirem momentos de picos da carga de trabalho no período da 11:00 as 14:59 horas, momento em que esteve vigente a configuração 2, eles também ocorreram nos períodos das 9:00 as 10:59 e das 15:00 as 16:59 horas, momento em que esteve vigente a configuração atual da TMA-SP (configuração 3); e

b) O chaveamento das configurações propostas no uso da RDL não precisa necessariamente ser ativado ao mesmo tempo e nem ter o mesmo tempo de vigência. No caso da Figura 86 e Figura 87, o chaveamento da configuração 3 para a configuração 2 , sob o ponto de vista do setor 2, não precisa ocorrer no mesmo instante de tempo do chaveamento da configuração 3 para a configuração 2 , sob o ponto de vista do setor 1. Além disso, os tempos de vigência de cada chaveamento não precisam ser os mesmos. Segundo o gráfico ilustrado na Figura 87, a configuração 2, em relação ao setor 2, deveria ser chaveada as 9:00 horas e permanecer até as 15:59, e não ser chaveada as 11:00 e ter permanecido até as 14:59, conforme o efetuado nas simulações deste trabalho. 
A Figura 88 representa um comparativo entre a carga de trabalho dos controladores de tráfego aéreo para os setores 1,2 e 3 , sem o uso da RDL, com a carga de trabalho do controlador de tráfego aéreo do setor 0 , com o uso da RDL.

Na Figura 88, como ilustrado no gráfico da Figura 69, no Estudo de Caso 1, o agrupamento dos setores 1, 2 e 3 no setor 0 proporcionou que um único controlador ficasse responsável pelo controle do espaço aéreo no lugar de 3 controladores. O controlador do setor 0 foi submetendo a uma carga de trabalho menor que os picos das cargas de trabalho dos controladores dos setores 1 e 2 ilustrados na Figura 86 e na Figura 87, respectivamente.

No gráfico da Figura 88, a carga de trabalho atribuída ao controlador de tráfego aéreo do setor 0 ficou abaixo da carga de trabalho atribuída ao controlador do setor 3 no período das 02:00 as 02:59.

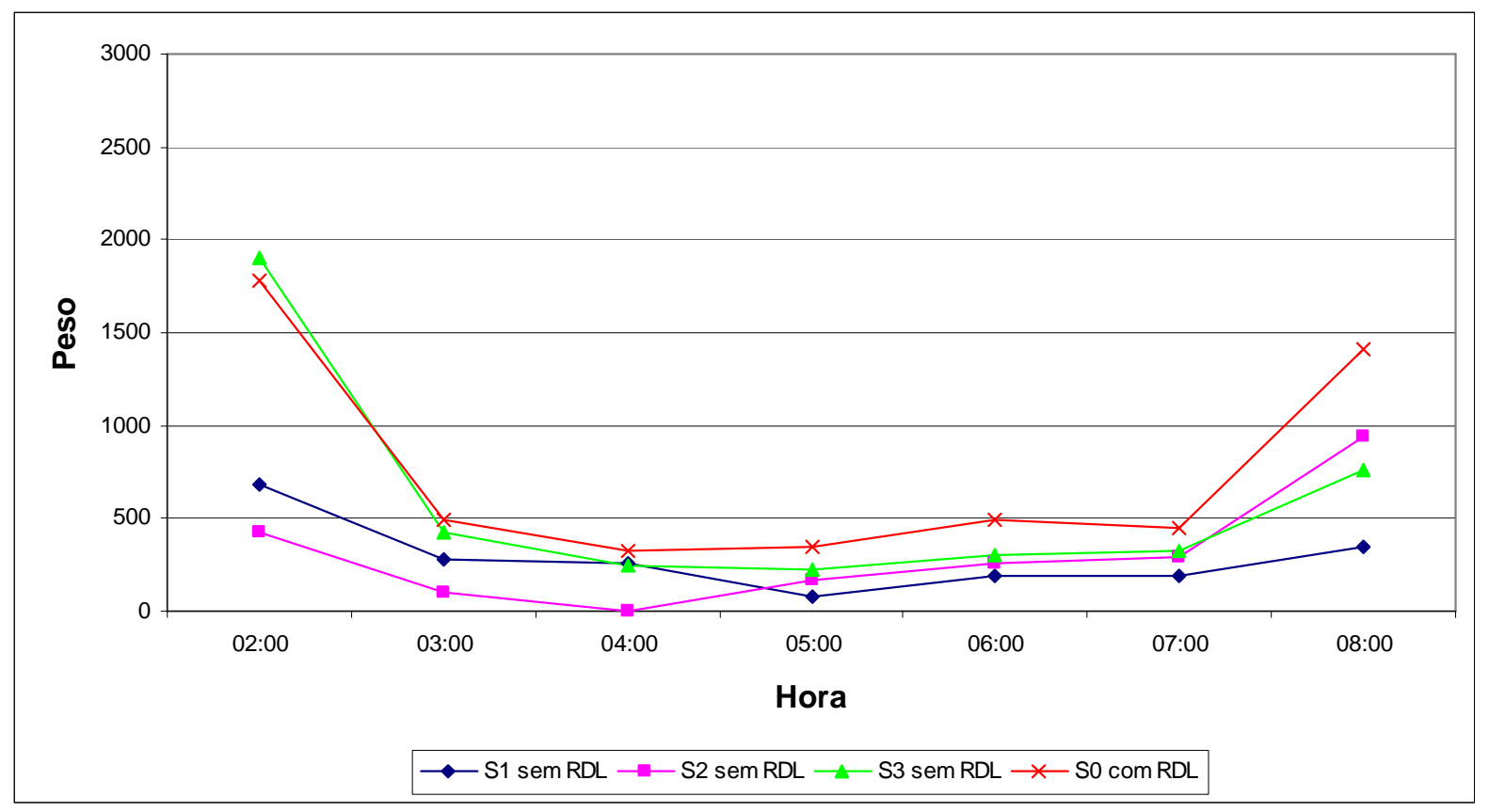

Figura 88 - Soma, por hora, dos pesos das tarefas realizadas pelos controladores nos setores $0,1,2$ e 3, sem e com o uso da RDL, esperado para 2015.

De acordo com a Figura 89, como na simulação efetuada para o tráfego do dia 30/08/2006, o uso da RDL para a configuração proposta não influenciou na somatória global da carga de trabalho dos controladores de tráfego aéreo. 


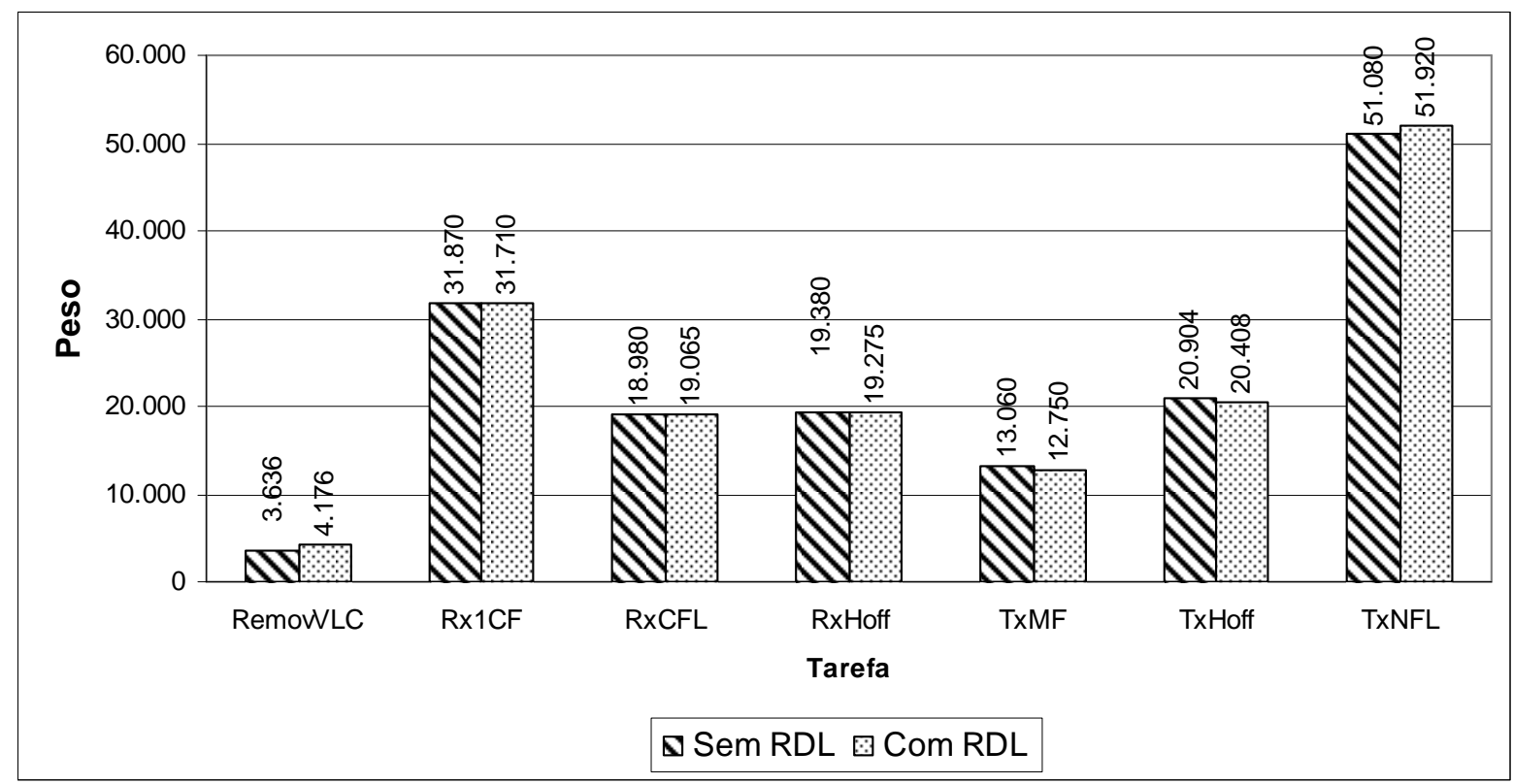

Figura 89 - Soma dos pesos das tarefas realizadas pelo controlador, sem e com o uso da RDL, esperado para 2015.

Pode-ser concluir que, como no Estudo de Caso 1, o uso da RDL proporcionou uma otimização da carga de trabalho do controlador de tráfego aéreo sem causar aumento na carga de trabalho global da TMA-SP.

\subsubsection{Análise do Número de Conflitos em Potencial}

No resultado das simulações realizadas utilizando o tráfego esperado para 2015, o crescimento do número de conflitos em potencial em relação ao tráfego de 04/09/2006, apresentou um aumento que não acompanhou a taxa de crescimento dos números de pouso e decolagem da TMA-SP. A Figura 90 e a Figura 91 apresentam a quantidade de conflitos detectados esperado para 2015, por setor, com e sem o uso da RDL na TMA-SP.

Segundo a Figura 90 e a Figura 91, o uso da RDL proporcionou uma redução nos números de conflitos detectados na TMA-SP, tanto para os setores que sofreram reconfiguração, como para os setores que não sofreram reconfiguração. Como no Estudo de Caso 1, pode-ser concluir, neste estudo de caso, que o uso da RDL proporcionou uma melhor gestão do tráfego aéreo devido a redução do número de conflitos em potencial, se comparado com o cenário sem o uso da RDL. 


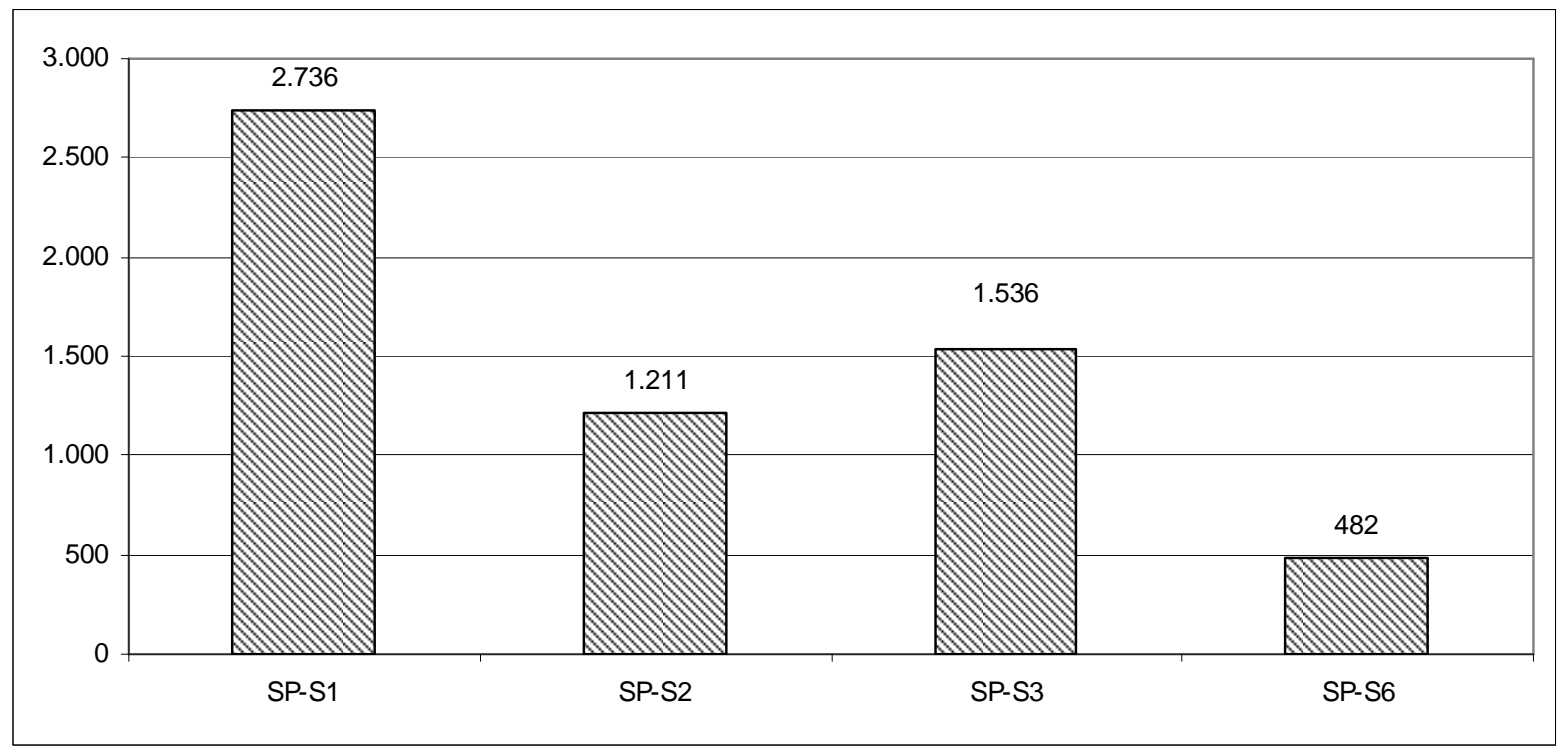

Figura 90 - Quantidade de conflitos detectados por setores na TMA-SP, sem o uso da RDL, esperado para 2015.

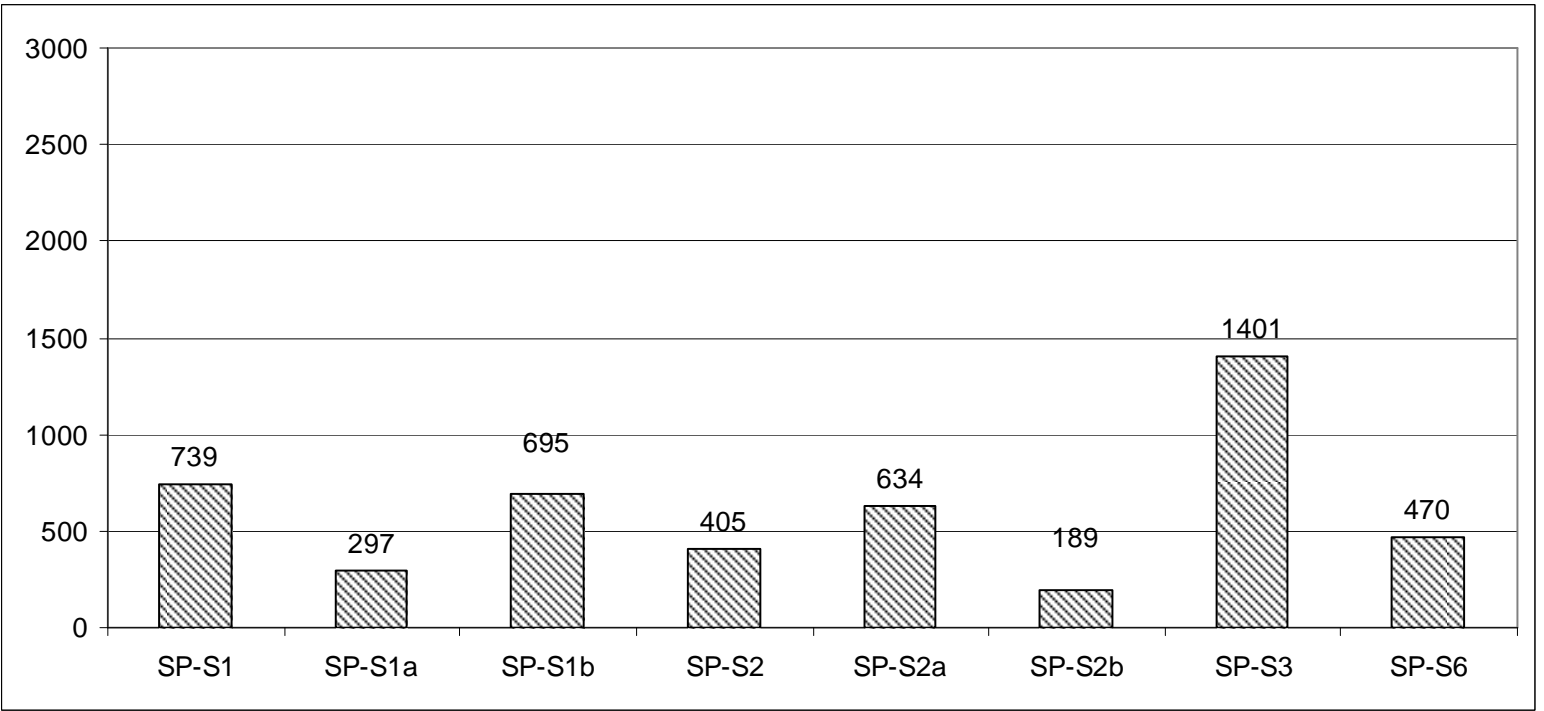

Figura 91 - Quantidade de conflitos detectados por setores na TMA-SP, com o uso da RDL, esperado para 2015.

\subsubsection{Análise da Função Complexidade}

Na simulação com o uso da RDL, o setor 1 foi dividido em dois setores (1a e 1b). Para estes setores, a média do valor da função complexidade resultou em 4 e 24, respectivamente, para os setores 1a e 1b. Já o setor 1 apresentou uma média da função complexidade de 30, na simulação com o uso da RDL. Esses resultados da função complexidade ficaram abaixo do 
resultado da função complexidade para o setor 1, obtida por simulações sem o uso da RDL (vide Figura 92 e Figura 93).

Com relação ao setor 2, como no Estudo de Caso 1, o uso da RDL proporcionou um aumento em sua complexidade. Sem o uso da RDL, o setor 2 teve média de 85 para a função complexidade. Com o uso da RDL, a média da função complexidade subiu para 109, o que representou um aumento de $22 \%$. O setor 3 , que não sofreu mudança em sua configuração com o uso da RDL, manteve a mesma média da função complexidade com e sem o uso da RDL. Maiores detalhes a respeito encontram-se na Figura 92 e a na Figura 93.

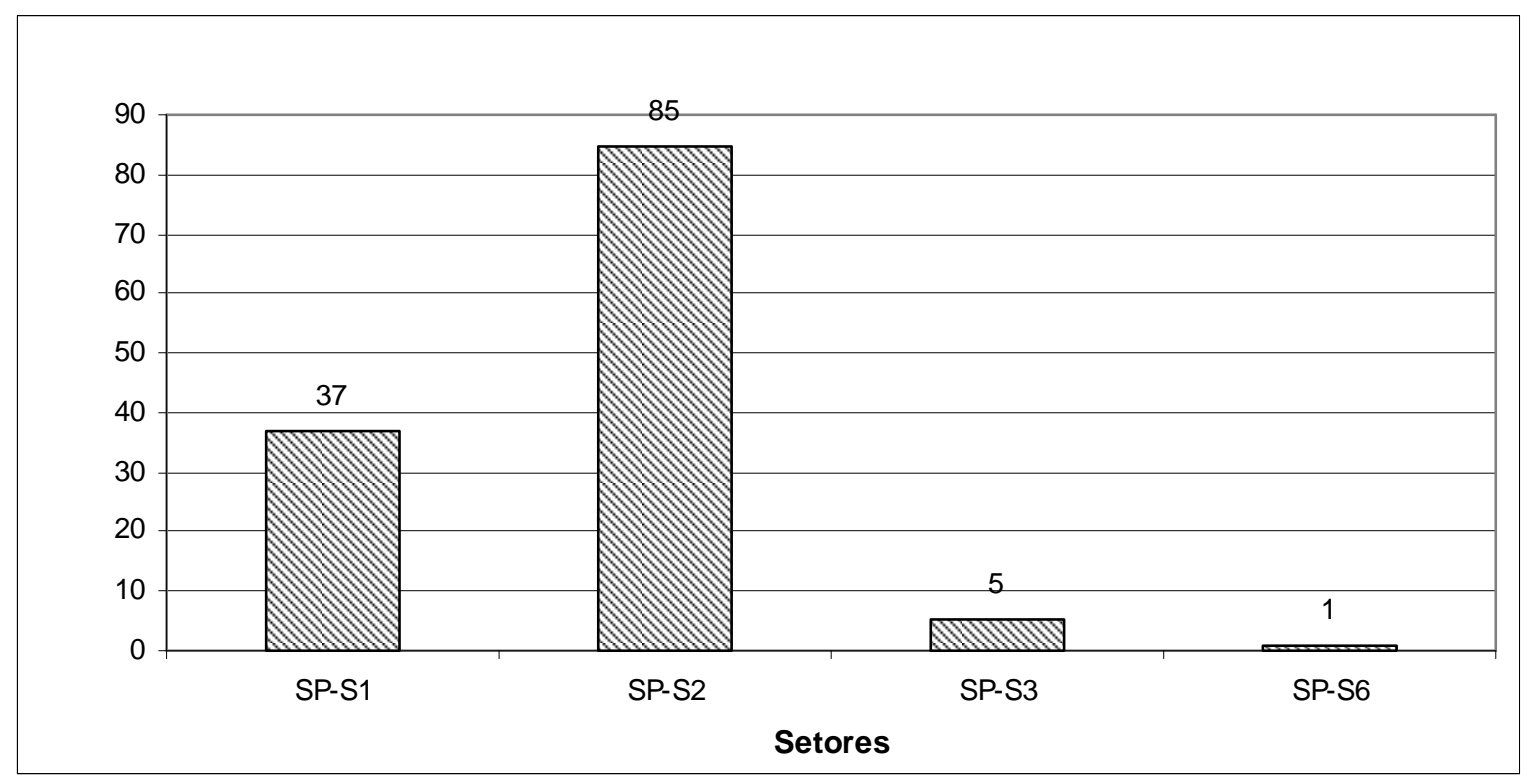

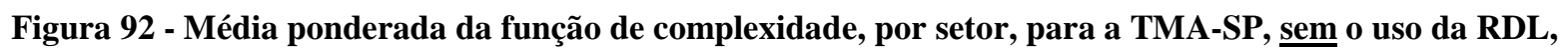
esperado para 2015.

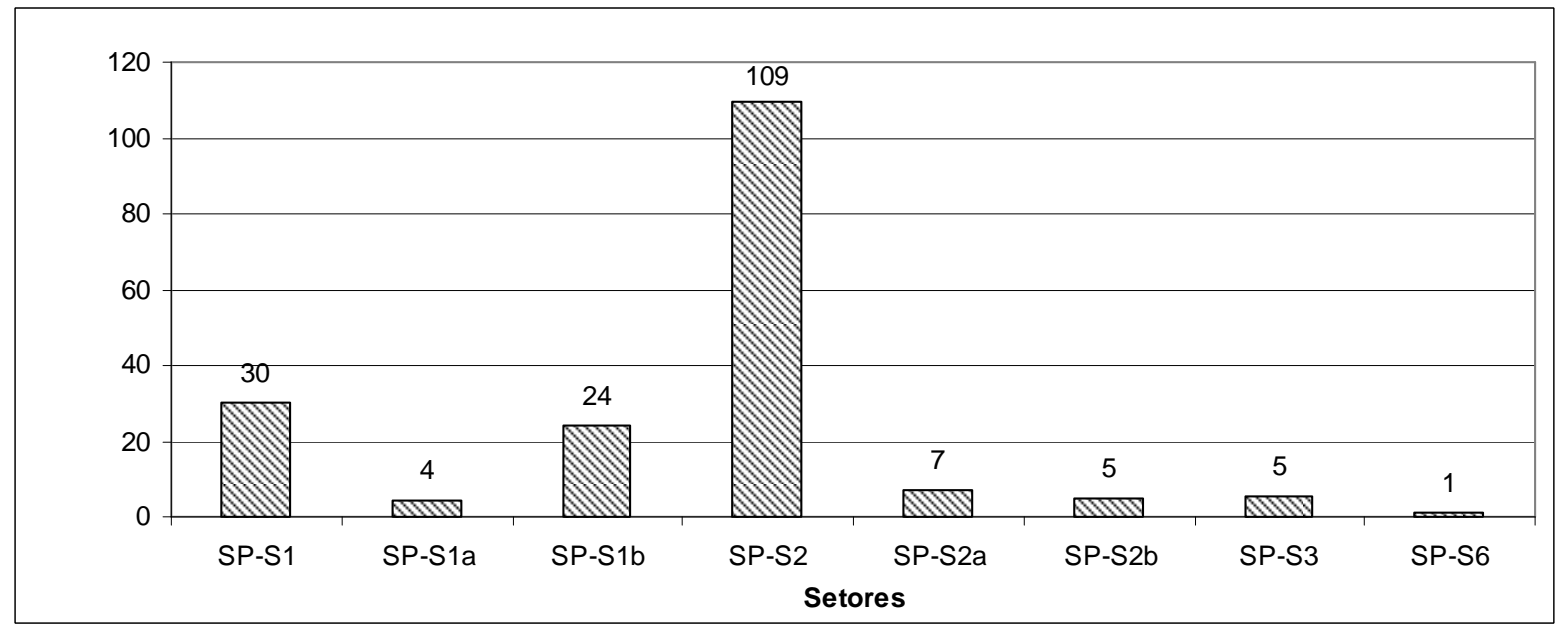

Figura 93 - Média ponderada da função de complexidade, por setor, para a TMA-SP, com o uSo da RDL, esperado para 2015. 
Como ilustra os gráficos na Figura 74, Figura 75, Figura 92 e Figura 93, mesmo com o aumento do volume de aeronaves previstos para 2015, a complexidade do setor 6 se manteve praticamente a mesma com e sem o uso da RDL, em relação ao tráfego esperado para 2015, e em relação a simulação feita no Estudo de Caso 1, considerando o tráfego de 30/08/2006. De forma geral, o uso da RDL não provocou um aumento na função complexidade se comprado com a simulação sem o uso da RDL.

\subsubsection{Análise do Número de Aeronaves Controladas Simultaneamente pelo Controlador de Tráfego Aéreo}

Um outro fator que teve um aumento nas simulações realizadas com o tráfego aéreo esperado para 2015 foi o número de aviões controlados simultaneamente por um controlador de tráfego aéreo. A Figura 94 e a Figura 95 apresentam o número de aeronaves controladas simultaneamente nos setores da TMA-SP, com e sem o uso da RDL.

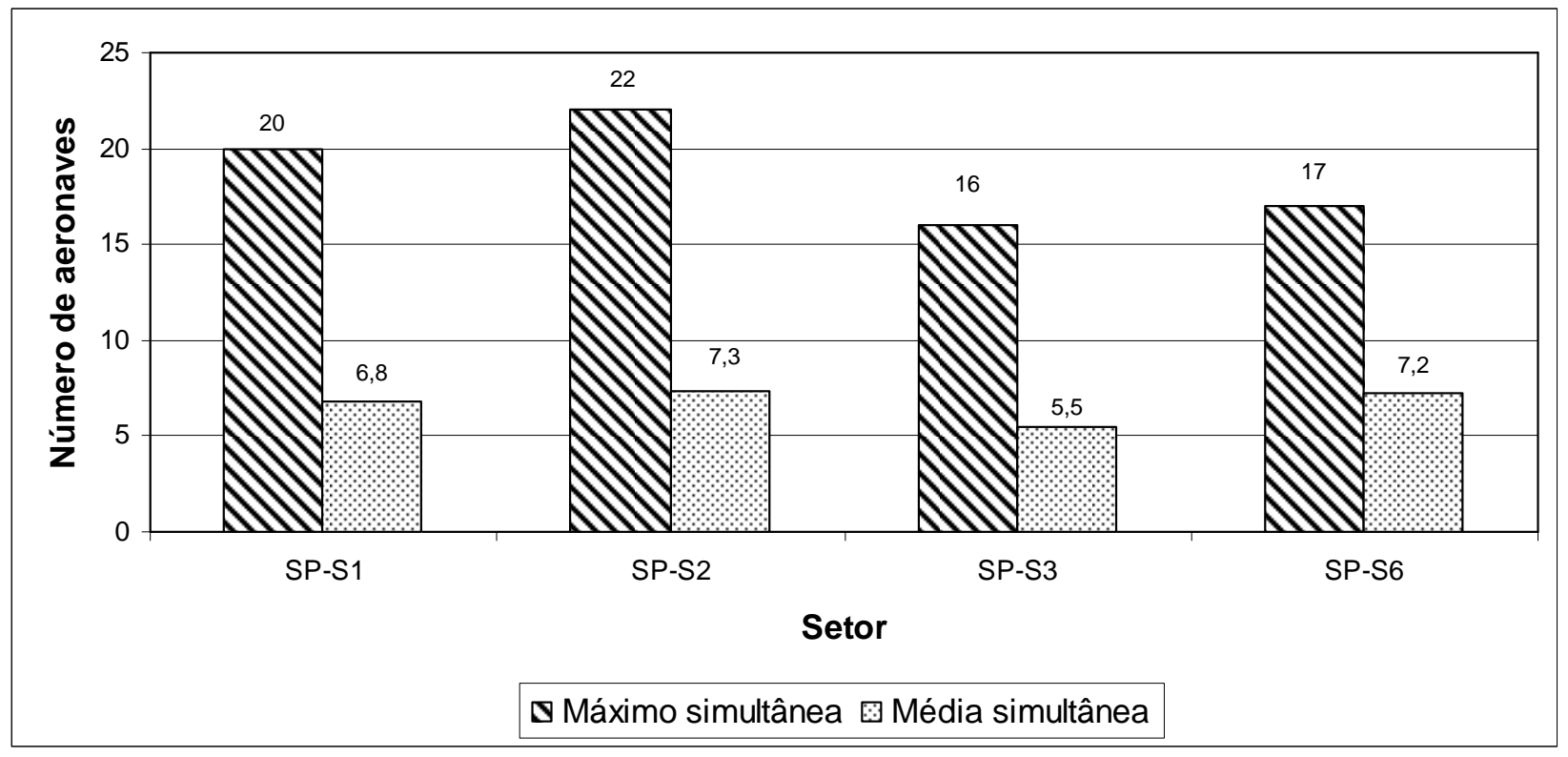

Figura 94 - Número de aeronaves controladas simultaneamente nos setores da TMA-SP, $\underline{\text { sem }}$ o uso da RDL, esperado para 2015. 


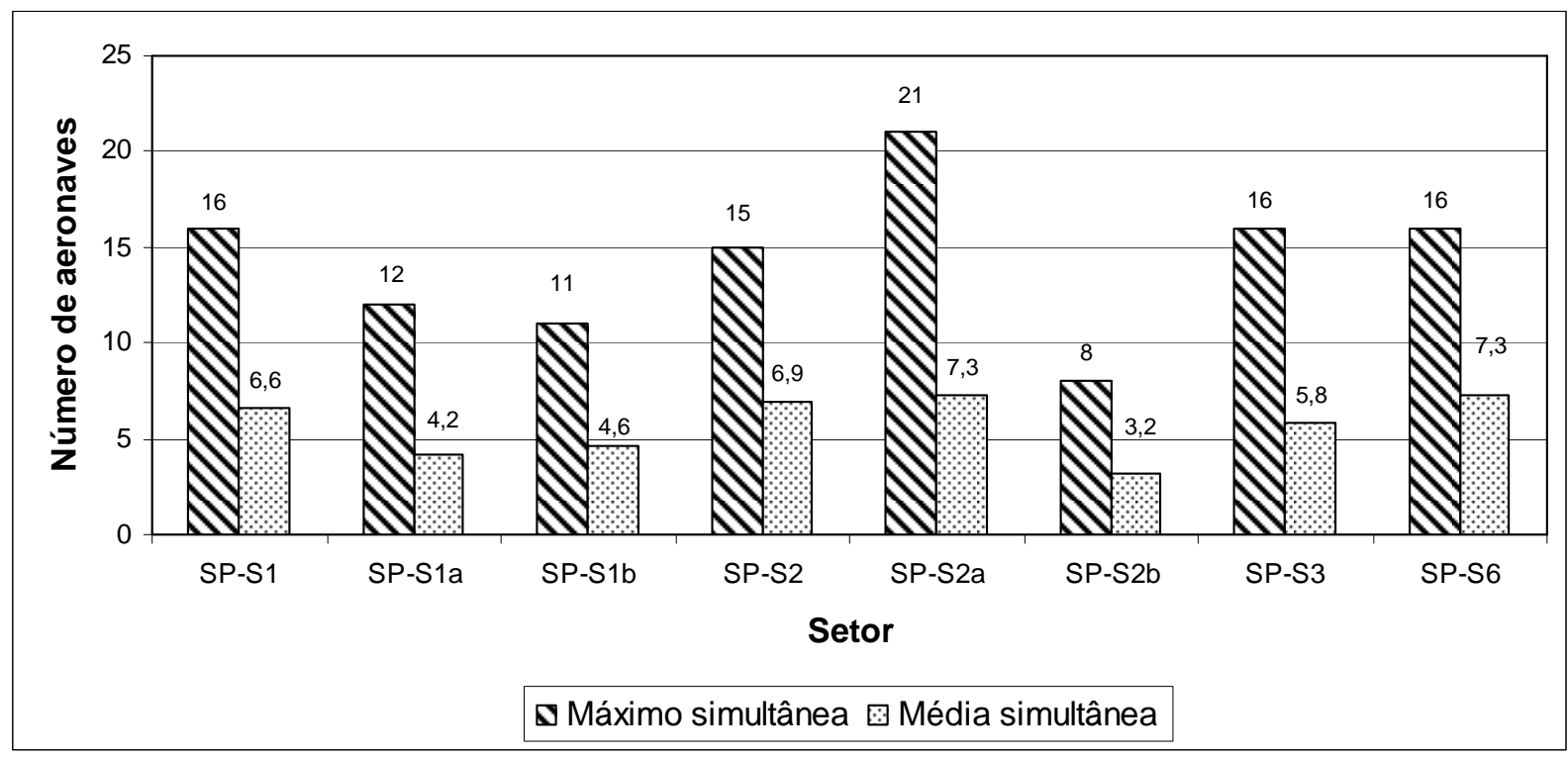

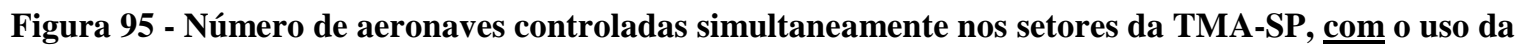
RDL, esperado para 2015.

Como no Estudo de Caso 1, o uso da RDL possibilitou uma redução no número de aeronaves controladas simultaneamente nos setores da TMA-SP que sofreram reconfiguração (setor 1, 1a, 1b, 2, 2a e 2b). O setor 3, que não sofreu reconfiguração, manteve o mesmo número de aeronaves controladas simultaneamente, com e sem o uso da RDL. Já o setor 6, que também não sofreu reconfiguração, teve reduzido o número de aeronaves controladas simultaneamente. Contudo, mesmo com o uso da RDL, com as configurações propostas, o número de aeronaves controladas simultaneamente ainda é maior em relação ao proposto pelo DECEA (DECEA, 2007), que é de no máximo 8 aeronaves controladas simultaneamente nos setores 1,2 e 3 , o que indica que outros mecanismos devem ser buscados para acomodar o aumento do tráfego aéreo esperado para os próximos anos.

\subsection{Considerações Finais do Capítulo}

Esse capítulo apresentou os resultados e análises das simulações realizadas utilizando o software RAMS Plus sobre cenários da TMA-SP. Foi investigado o uso da RDL em dois estudos de casos, o primeiro com base no tráfego com alta demanda de aeronaves, e o segundo, baseado no crescimento esperado para 2015 de um tráfego com demanda atual típica de aeronaves. As conclusões e recomendações a respeito são apresentadas no próximo capítulo. 


\section{Considerações Finais do Trabalho}

Este capítulo apresenta conclusões referentes a este trabalho de pesquisa, algumas recomendações para o uso da RDL e do software utilizado nas simulações computacionais, bem como propostas de trabalhos futuros que podem ser desenvolvidos.

\subsection{Comentários Finais sobre o Conteúdo Apresentado neste Trabalho de Pesquisa}

Neste trabalho de investigação científica, o impacto do uso da Re-setorização Dinâmica (RD), mais especificamente a Re-setorização Dinâmica Limitada (RDL), foi analisado utilizando-se dois estudos de caso que tiveram como cenário a Área de Controle Terminal de São Paulo (TMA-SP). O primeiro estudo de caso, utilizando o tráfego aéreo com alta demanda de aeronaves, e o segundo, baseado no tráfego aéreo esperado para 2015. Ambos os estudos de casos foram investigados sob quatro pontos de vista, a saber: análise da carga de trabalho do controlador de tráfego aéreo; análise do número de conflitos em potencial nos setores do espaço aéreo; análise da função complexidade dos setores do espaço aéreo; e análise do número de aeronaves controladas simultaneamente por cada controlador de tráfego aéreo.

Em todas as análises realizadas, o uso da RDL proporcionou um balanceamento da carga de trabalho do controlador de tráfego aéreo, acarretando uma diminuição no número de conflitos em potencial entre aeronaves, uma diminuição no número de aeronaves controladas simultaneamente por um controlador de tráfego aéreo, além de não interferir de forma global na função complexidade dos setores da TMA-SP. 


\subsection{Recomendações quanto ao Uso da RDL}

No caso do uso da RDL, devido a variação do tráfego, recomenda-se que sejam construídos cenários alternativos para o órgão de controle considerado (APP ou ACC), com algumas setorizações do espaço aéreo. A construção destas configurações deve ser baseada no histórico do tráfego de aeronaves vivenciado em anos anteriores e nos conhecimentos adquiridos pelos controladores de tráfego aéreo ao longo do tempo.

Todas as configurações de cenário devem ser validadas utilizando uma ferramenta de simulação computacional a fim de se verificar a efetividade no balanceamento da carga de trabalho dos controladores de tráfego aéreo. Antes de se implantar a RDL, todas as configurações do espaço aéreo devem ser muito bem conhecidas por todos os controladores de tráfego aéreo envolvidos no processo.

Para se determinar o momento de chaveamento entre as configurações, recomenda-se que seja implantado, no órgão de controle de tráfego aéreo, uma ferramenta capaz de prever o crescimento do tráfego em um instante futuro, determinando qual a melhor configuração que atende ao futuro tráfego, bem como os instantes no tempo que essa nova configuração deva ser ativada e desativada. Esta ferramenta poderia ser implantada em um ponto central do órgão de controle, como por exemplo, no local de trabalho do supervisor do controle de tráfego aéreo.

Uma vez determinada qual a configuração que será usada e em que momento ocorrerá a troca de configuração de cenários do espaço aéreo, todos os controladores devem ser avisados com antecedência do momento da troca e para qual configuração ocorrerá o chaveamento.

Com o uso da RDL, as bordas dos setores podem sofrer uma re-configuração, mantendo a mesma quantidade de setores de um espaço aéreo. Existe também a possibilidade do agrupamento ou divisão de setores. Criar ou agrupar setores envolve inicialmente dois fatores: o número efetivo de controladores de tráfego aéreo, alocados nos respectivos órgãos de controle; e na disponibilidade física de faixas de freqüência de comunicação.

Quanto ao primeiro fator, uma forma de acomodar esta questão é ter uma gestão mais dinâmica do efetivo dos controladores durante os turnos de trabalho. As trocas das configurações dos setores podem coincidir com a troca de turno dos controladores. E o número de controladores não necessariamente precisa ser o mesmo em todos os turnos. 
Já o segundo fator, limita a divisão do espaço aéreo envolvido, pois o número de radiofrequiências disponíveis para a comunicação por voz entre pilotos e controladores de tráfego aéreo atualmente é limitada. Até porque, como apresentado anteriormente neste trabalho, um excesso de divisão dos setores pode impactar negativamente na carga de trabalho do controlador de tráfego aéreo, o que não é desejável.

\subsection{Comentários a Respeito do Software Utilizado nas Simulações Computacionais}

Algumas condições de contorno tiveram que ser adotadas neste trabalho de pesquisa porque o software de simulação utilizado, o RAMS Plus, não conseguiu atender a algumas características da TMA-SP. Primeiro, os setores terminais 4 e 5 da TMA-SP controlam apenas as aeronaves que estão pousando em seus respectivos aeroportos. Quando uma aeronave decola de SBGR (Guarulhos) ou SBSP (São Paulo), elas são controlados diretamente pelos setores adjacentes aos setores terminais 4 e 5, no caso pelos setores alimentadores 1 e 3 . Segundo, não foi possível criar um setor contido em outro setor sem que uma borda do setor interno tenha ligação com o setor externo, como acontece no caso da configuração proposta para os setores 0,4 e 5, em que o setor 0 é composto pela união dos setores 1,2 e 3 .

Para ambos os casos, a ferramenta RAMS Plus não atende aos requisitos desejados. Como recomendação é interessante que:

- No software de simulação utilizado seja possível configurar os setores terminais do espaço aéreo de uma TMA de tal forma que eles controlem apenas os vôos que pousam em seus respectivos aeroportos. Além disso, quando um vôo decolar destes aeroportos, é desejável que eles sejam controlados diretamente pelos setores alimentadores adjacentes aos setores terminais que contêm o aeroporto; e

- Seja possível criar um setor contido em outro setor sem que uma borda do setor interno tenha ligação com o setor externo. 


\subsection{Propostas de Trabalhos Futuros}

A seguir são apresentadas algumas sugestões para trabalhos futuros relacionados com o assunto investigado neste trabalho de pesquisa:

i. Investigação da aplicação da RDL em outras situações: nos estudos de caso deste trabalho, foi abordado o uso da RDL devido à variação da quantidade de aeronaves no espaço aéreo. Contudo, existem outras situações descritas no Capítulo 3 em que a RDL pode ser aplicada, a saber:

- utilização da RDL devido a indisponibilidade de equipamentos, como o equipamento radar;

- utilização da RDL devido a mudanças climáticas; e

- utilização da RDL devido ao uso especial do espaço aéreo.

ii. Análise do comportamento da carga de trabalho do controlador de tráfego aéreo nos momentos de chaveamento de cenários e em função da quantidade de configurações de cenários existentes: um ponto importante no uso da RDL é o momento em que deve ser feito o chaveamento entre configurações de setores, além do número de configurações de setores existentes em um espaço aéreo. Estes aspectos podem afetar diretamente a carga de trabalho dos controladores de tráfego aéreo;

iii. Criação de um software de apoio a decisão, de predição da variação do tráfego aéreo, atrelado ao uso da RDL: um outro ponto que pode ser abordado em trabalhos futuros é a interação de um software de predição da variação futura do tráfego auxiliando no uso da RDL. Um software que consiga informar qual o volume futuro de tráfego em um espaço aéreo pode ser usado para sugerir a necessidade de redefinição da configuração dos setores do espaço aéreo;

iv. Construção de um software, pré-tático, que auxilie a análise de um espaço aéreo e proponha configurações de cenários para o uso da RDL: uma sugestão é usar a teoria de algoritmos genéticos para construção desse software, conforme sugerido em (DELAHAYE, ALLIOT, SCHOENAUER, 1993 e 1994); 
v. Investigação da possibilidade do uso da RDI: este trabalho de investigação científica leva a crer que o futuro provável da RDL (RD Limitada) é a RD Irrestrita (RDI). Uma outra possível linha de pesquisa é a exploração do uso da reconfiguração on-line dos setores do espaço aéreo, considerando possíveis algoritmos eficientes de tempo-real, a análise do impacto causado pelos setores com fronteiras variáveis na carga de trabalho dos controles de tráfego aéreo e a avaliação do uso da RDI versus o uso da RDL; e

\section{vi. Investigação do impacto do uso da RDL e/ou da RDI no tamanho das equipes de} controladores de tráfego aéreo: com o uso da RD, quer seja limitada quer seja irrestrita, o número de controladores de tráfego aéreo necessário em determinados instantes de tempo pode variar em função da necessidade de balanceamento da carga de trabalho envolvida no controle do tráfego aéreo. Pode-se fazer uma análise do custobenefício da utilização deste conceito sob o ponto de vista da variação do tamanho das equipes.

\subsection{Conclusão}

Este trabalho de pesquisa investigou o impacto do uso da Re-setorização Dinâmica (RD), em particular a Re-setorização Dinâmica Limitada (RDL), na carga de trabalho do controlador de tráfego aéreo, por meio de simulações computacionais utilizando um software de simulação de tráfego aéreo. Os resultados e as análises das simulações mostraram que o uso da RDL ajuda a balancear a carga de trabalho dos controladores de tráfego aéreo durante os momentos de baixa ou alta demanda de aeronaves, gerando um menor estresse aos controladores de tráfego aéreo envolvidos, o que pode implicar em uma maior eficiência e segurança no controle de tráfego aéreo.

Contudo, o uso da RDL não é uma condição exaustiva para acomodar o crescimento de transporte aéreo sem comprometer o nível de segurança. Outros investimentos e pesquisas devem ser feitos, como por exemplo, a ampliação da capacidade dos aeroportos, o desenvolvimento de aeronaves com maior capacidade de transporte de passageiros, o desenvolvimento de um sistema de comunicação entre piloto e controlador de tráfego aéreo mais confiável e seguro, entre outros. 


\section{Glossário}

Neste glossário são apresentados formalmente alguns termos ou conceitos úteis para uma consulta rápida, não sendo estritamente necessários para o entendimento deste trabalho de pesquisa, e foram construídos majoritariamente baseados nas referências (IAC 100-12, 2006; SALLES, 2006).

Aeródromos - São locais, no solo ou água, onde há partida, chegada e movimento de aeronaves.

Aeródromo Controlado - Aeródromo no qual se presta serviço de controle de tráfego aéreo para o tráfego do aeródromo.

Aeronave - Aparelho manobrável em vôo que pode sustentar-se e circular no espaço aéreo, mediante reações aerodinâmicas, apta a transportar pessoas ou coisas.

Aeroportos - São aeródromos que possuem instalações e facilidades para apoio de operações de aeronaves.

Aerovia - Área de Controle, ou parte dela, disposta em forma de corredor, e provida de auxílios à navegação.

Aproximação por Instrumento - Aproximação na qual todo o procedimento é executado com referência a instrumentos.

Aproximação Radar - Aproximação executada por uma aeronave sob orientação de um controlador radar.

Aproximação Visual - Aproximação em vôo IFR, quando parte ou a totalidade do procedimento de aproximação por instrumentos não se completa e se realiza com referência visual do solo.

Área de Controle - Espaço aéreo controlado que se estende para cima a partir de um limite especificado sobre o terreno.

Área de Controle Terminal - Área de controle situada geralmente na confluência de rotas ATS e nas imediações de um ou mais aeródromos.

Avião ou Aeroplano - é uma aeronave, mais pesada que o ar, propulsada mecanicamente, e que deve sua sustentação em vôo principalmente às reações aerodinâmicas exercidas sobre superfícies que permaneçam fixas.

Centro de Controle de Área - Órgão estabelecido para prestar serviço de controle de tráfego aéreo aos vôos controlados nas áreas de controle sob sua jurisdição.

Contato Radar - Situação que ocorre quando o eco radar ou símbolo de posição radar de determinada aeronave é visto e identificado numa tela radar.

Controle de Aproximação - Órgão estabelecido para prestar serviço de controle de tráfego aéreo aos vôos controlados que chegam ou saem de um ou mais aeródromos.

Controle Radar - Termo usado para indicar que na provisão do serviço de controle de tráfego aéreo estão sendo utilizadas, diretamente, informações oriundas do radar.

Identificação Radar - Processo de se relacionar um eco radar ou símbolo de posição radar com uma determinada aeronave. 
Informação de Tráfego Aéreo - Informação emitida por um órgão ATS para alertar um piloto sobre outro tráfego aéreo conhecido ou observado que possa estar nas imediações da posição ou rota desejada do vôo, e para auxiliá-lo a evitar uma colisão.

Nível de Cruzeiro - Nível que se mantém durante uma etapa considerável do vôo.

Número de coordenação - Número de interações entre controladores de tráfego aéreo de setores diferentes.

Órgão de Controle de Tráfego Aéreo - Expressão genérica que se aplica, segundo o caso, a um Centro de Controle de Área, Controle de Aproximação ou Torre de Controle de Aeródromo.

Órgãos dos Serviços de Tráfego Aéreo - Expressão genérica que se aplica, segundo o caso, a um órgão de controle de tráfego aéreo ou a um órgão de informação de vôo.

Plano de Vôo - Informações específicas, relacionadas com um vôo planejado ou com parte de um vôo de uma aeronave, fornecidas aos órgãos que prestam serviços de tráfego aéreo.

Procedimento de Aproximação por Instrumento - Série de manobras predeterminadas realizadas com o auxílio dos instrumentos de bordo, com proteção específica contra os obstáculos, desde o fixo de aproximação inicial ou, quando aplicável, desde o princípio de uma rota de chegada, até um ponto a partir do qual seja possível efetuar o pouso e, caso este não se realize, até uma posição na qual se apliquem os critérios de circuito de espera ou de margem livre de obstáculos em rota.

Radar - Equipamento de rádiodeteção que fornece informações de distância, azimute e/ou elevação de objetos.

Radar Primário - Sistema radar que utiliza sinais de rádio refletidos.

Radar Secundário - Sistema radar no qual um sinal de rádio emitido por uma estação radar provoca a transmissão de um sinal rádio de outra estação.

Rota - Projeção sobre a superfície terrestre da trajetória de uma aeronave cuja direção, em qualquer ponto, é expressa geralmente em graus a partir do Norte (verdadeiro ou magnético).

Separação - Distância que separa aeronaves, níveis ou rotas.

Separação não-Radar - Separação utilizada, quando a informação de posição da aeronave é obtida de fonte que não seja radar.

Separação Radar - Separação utilizada, quando a informação de posição da aeronave é obtida de fonte radar.

Serviços de Tráfego de Área - Expressão genérica que se aplica, segundo o caso, aos serviços de informação de vôo, alerta, assessoramento de tráfego aéreo, controle de tráfego aéreo (controle de área, controle de aproximação ou controle de aeródromo).

Subida em Cruzeiro - Técnica de cruzeiro de um avião que resulta em um aumento da altitude à medida que diminui o peso do avião.

Táxi - Movimento autopropulsado de uma aeronave sobre a superfície de um aeródromo, excluídos o pouso e a decolagem, mas, no caso de helicópteros, incluído o movimento sobre a superfície de um aeródromo, a baixa altura e a baixa velocidade.

Torre de Controle de Aeródromo - Órgão estabelecido para proporcionar serviço de controle de tráfego aéreo ao tráfego de aeródromo. 
Tráfego Aéreo - Todas as aeronaves em vôo ou operando na área de manobras de um aeródromo.

Transferência Radar - Ato pelo qual a identificação e a responsabilidade do controle radar sobre uma aeronave são transferidas de um controlador para outro, sem que haja interrupção da progressão geral das aeronaves identificadas.

Vetoração Radar - Provisão de orientação para navegação às aeronaves, em forma de rumos específicos, baseada na observação de uma apresentação radar.

Vigilância Radar - Emprego do radar para proporcionar às aeronaves informação e assessoramento sobre desvios significativos com respeito à trajetória nominal de vôo.

Vôo IFR - Vôo efetuado de acordo com as regras de vôo por instrumentos

Vôo VFR - Vôo efetuado de acordo com as regras de vôo visual.

Zona de Controle - Espaço aéreo controlado que se estende do solo até um limite superior especificado.

Zona de Tráfego de Aeródromo - Espaço aéreo de dimensões definidas estabelecido em torno de um aeródromo para proteção do tráfego do aeródromo. 


\section{Referências Bibliográficas}

AIC 12/06 - Rotas especias de aviões sob a TMA São Paulo. Departamento de Controle do Espaço Aéreo - DECEA, Divisão de informações aeronáuticas, 28 de Setembro de 2006.

ANAC - Agência Nacional de Aviação Civil. Home page. Disponível em: http://www.anac.gov.br. Acess em abril de 2007.

AIP Brasil. Publicação de informação aeronáutica do Brasil. Departamento de Controle do Espaço Aéreo - DECEA, 2004.

ASN - Aviation Safety Network. Home page. Disponível em: http://aviationsafety.net/database/record.php?id=19790726-1\&lang=en. Acesso em abril de 2007.

BOEING - Boeing Commercial Airplane Group. Air traffic management concept baseline definition. Nextor Report \# RR-97-3. October 31, 1997.

FAA - Federal Aviation Administration. Aeronautical Information Manual. Official Guide to Basic Flight Information and ATC Procedures. August 3, 2006.

DECEA - Departamento de Controle do Espaço Aéreo. Carta de Área Rio-São Paulo. DECEA, 2004.

------ Home page. Disponível em: http://www.decea.gov.br. Acesso em Julho de 2006. DECEA, 2006.

-----. Modelo operacional do controle de aproximação de São Paulo (App-Sp). DECEA, 2007.

DELAHAYE, D.; ALLIOT, J.; SCHOENAUER, M.; FARGES, J. Genetic algorithms for partitioning air space. In: IEEE CONFERENCE ON ARTIFICIAL INTELLIGENCE FOR APPLICATIONS. Proceedings CAIA'94. New York, 1994. P. 291-294.

Genetic algorithms for portioning regroupement of Air Traffic Control sector. In: PROCEEDINGS OF THE CONFERENCE ON EVOLUTIONARY PROGRAMMING, 1995.

CGNA - Centro de Gerenciamento de Navegação Aérea. Home page. Disponível em: http://www.cgna.gov.br. Acesso em outubro de 2006.

EUROCONTROL. Adaption of worckload model by optimisation algorithms and sector capacity assessment. EEC Note No. 07/05. Project COCA, 2005. 
ER-1: Match Airspace Design to Demands. Design and manage en route airspace to accommodate complexity and congestion, 2001.

FARIAS NETO, J. G. Choque de gestão: do Vôo 1907 ao apagão aéreo do Brasil. Rio de Janeiro: Ciência Moderna, 2007.

HADLEY, J.; SOLLENBERG, R.; D’ARCY, J.; BASSETT, P. Interfacility boundary adjustment. The Federal Aviation Administration William J. Hughes Technical Center. Atlantic City International Airport, New Jersey, 2000.

HADLEY, J.; SOLLENBERGER, R. Dynamic resectorization of airspace boundaries between adjacent air route traffic control centers. The Federal Aviation Administration William J. Hughes Technical Center. Atlantic City International Airport, New Jersey, 2001.

HUPALO, M. F. Analise da area de controle terminal São Paulo (TMA-SP) por meio de simulação (Fast Time Simulation). Tese (Mestrado). ITA - Instituto Tecnológico da Aeronautica, São José dos Campos, 2003.

IAC - Instituto de Aviação Cilvil. Demanda detalhada dos aeroportos Brasileiros, Vol 1. AIC, 2005a.

-----. Demanda detalhada dos aeroportos Brasileiros, Vol 2. AIC, 2005b.

ICA 100-11. Plano de Vôo. Comando da Aeronáutica, 2000.

ICA 100-12. Regras do ar e serviços de tráfego aéreo. Comando da Aeronáutica, 2006.

ICAO - International Civil Aviation Organization. Specimen air traffic control operations manual for implementation reduced vertical separation minimum. ICAO, 2004.

- Outlook for Air Transport to the Year 2010. ICAO, Circular 281, 2000.

-. Rules of The Air and Air Traffic Services. ICAO, Document 4444 RCA/501, 1996.

INFRAERO. Home page. Disponível em : http://www.infraero.gov.br. Acesso em Novembro 2006.

IMA 100-12. Regras do ar e serviços de tráfego aéreo. Departamento de Controle do Espaço Aéreo Divisão de Informações Aeronáuticas, 5ª Modificação (1999), 2002.

IMA 102-9. Características mínimas dos equipamentos Nav/Com a bordo de aeronaves. Comando da Aeronáutica, 1997. 
KOPARDEKAR, P. Measurement and prediction of dynamic density. Federal Aviation Administration, NASA Ames Research Center, Moffett Field, CA, USA. 2003.

MASAlONIS, A.; CALlAHAM, M.; WANKE, C. Dynamic density and complexity metrics for realtime traffic flow management. Center for Advanced viation System Development (CAASD), The MITRE Corporation, McLean, VA, USA. 2003.

MCA 53-1. Manual do especialista em informação aeronáutica. Comando da Aeronáutica, 2000.

MMA 100-30. Planejamento de pessoal ATC e horário de trabalho. Comando da Aeronáutica, 1990.

NASA - National Aeronautics and Space Administration. An evaluation of air traffic control complexity. Wyndemere Incorporated, NASA-ARC Contract \# NAS2-14284, October 1996.

NAVARRETE, M. C. Modelo de previsão de posição futura de aeronaves para uso em sistemas de vigilância do espaço aéreo. Tese (Mestrado). Escola Politécnica da Universidade de São Paulo, 2006.

NCAG 2 - Nova circulação aérea geral, fase 2. Comando da Aeronáutica, Departamento de Controle Tráfego Aéreo - DCEA. 10 de junho de 2004. Disponível em: http://www.decea.gov.br. Acesso em maio de 2005.

NLR - National Aerospace Laboratory. Review of air traffic management-related accidents worldwide: 1980 - 2001. NLR, TP-2003-376, 2003.

OCHIENG, W.Y et al. GPS integrity and potencial impact on aviation safety. The Journal of Navigation, 56, p.51-65, 2003.

PAWLAK, W. S.; BOWLES, A.; GOEL, V.; BRINTON, C. B. Initial evaluation of the dynamic resectorization and route coordination (DIRECT) system concept. NASA Final Report \#NAS2-97057. Boulder, CO: Wyndemere Incorporated, 1997.

RAMS-Plus - Reorganized ATC Mathematical Simulator - Plus. RAMS-plus data manual. ISA Software, Release 5.24, 2005.

RIZZI, J.; MULLER, C. Um modelo matemático de auxílio para o problema de controle do tráfego aéreo. ITA - Instituto Tecnológico da Aeronautica, São José dos Campos, 2003.

SALLES, C. R. Regulamento de tráfego aéreo. Disponível em: http://www.airandinas.com. Acesso em Junho de 2006. 
STEIN, E.; ROCCO, P.; SOLLENBERGER L. Dynamic resectorization in air traffic control: A human factors perspective. 2005.

STEIN, E. S. Air traffic controller workload: an examination of workload probe. 1985.

TABER, N.; WOODWARD, F.; SMALL, D. Limited dynamic resectorization casebook. Corporation Center for Advanced Aviation System Development. MITRE, 2000.

TRANDAC, H.; DUONG, V. Optimized sectorization of airspace with constraints. In: 5TH AIR TRAFFIC MANAGEMENT R\&D SEMINAR, Budapest, 2003.

VINK, A. EATCHIP medium term conflict detection. In: 1ST USA / EUROPE ATM R\&D SEMINAR, 1997

WILHELMSEN, H.; BROWN, W. L.; COCHRAN, K. D.; CRONE, C. W.; LIND, A. M. T.; PETRILLO, T. A.; WIKEN, R. T. Dynamic resectorization in en route air traffic control report 1: Program overview and DR concept (92PM-En Route Infrastructure0001). Lexington,MA: MIT Lincoln Laboratory, 1999a.

-----. Dynamic resectorization in en route air traffic control report 2: DR issues and scenarios (92PM-En Route Infrastructure-0002). Lexington, MA: MIT Lincoln Laboratory, 1999b.

-----. Dynamic resectorization in en route air traffic control report 3: Program overview and DR concept (92PM-En Route Infrastructure-0001). Lexington MA: MIT Lincoln Laboratory, 1999c.

Dynamic resectorization in en route air traffic control report 4: DR issues and scenarios (92PM-En Route Infrastructure-0002). Lexington, MA: MIT Lincoln Laboratory, 1999d.

Dynamic resectorization in en route air traffic control report 5: DR issues and scenarios (92PM-En Route Infrastructure-0002). Lexington, MA: MIT Lincoln Laboratory, 1999e.

Wyndemere. Dynamic resectorization: Accommodating increased flight flexibility. Technical report. Disponivel em: http://www.wynde.com/papers/atca97-2.pdf. Boulder, CO, 1997. 
ANEXO I - Movimento de Aeronaves por Hora na TMA SP e em seus Aeroportos

Movimento de aeronaves por hora na TMA-SP, dia 30/08/2006

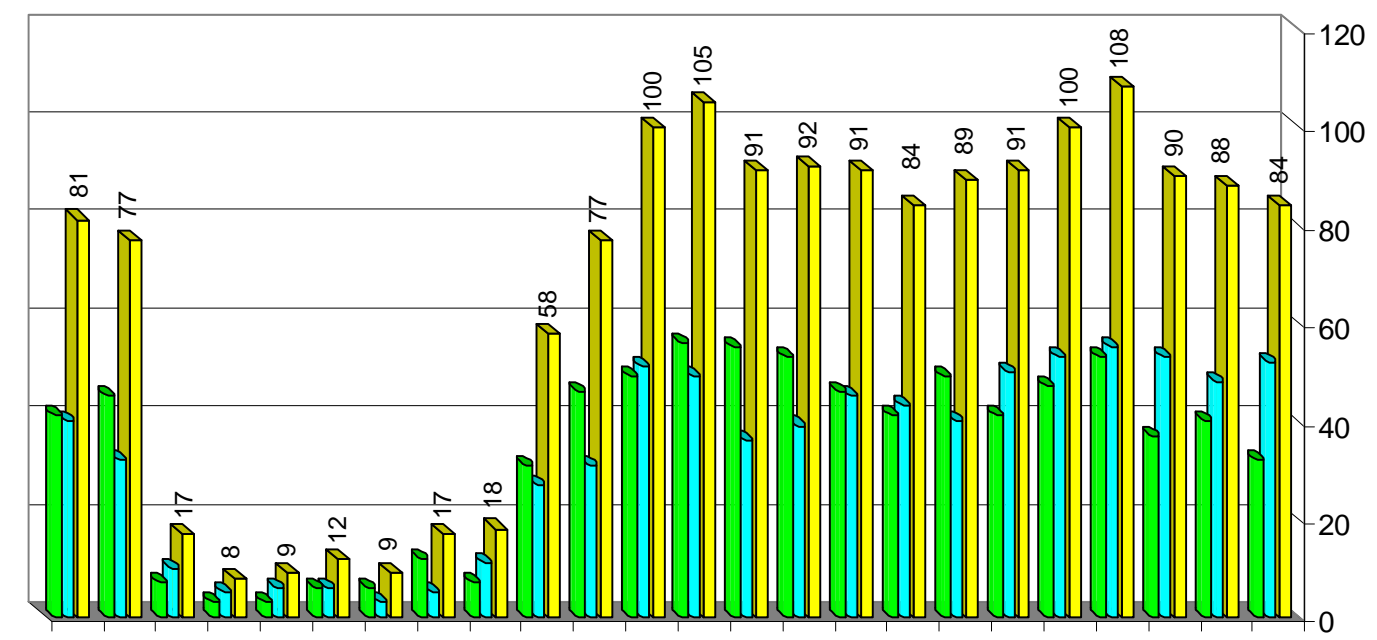

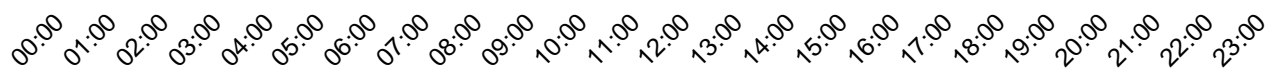

Partida $\square$ Chegada $\square$ Total

Movimento de aeronaves por hora no aeroporto de SBGR, dia 30/08/2006

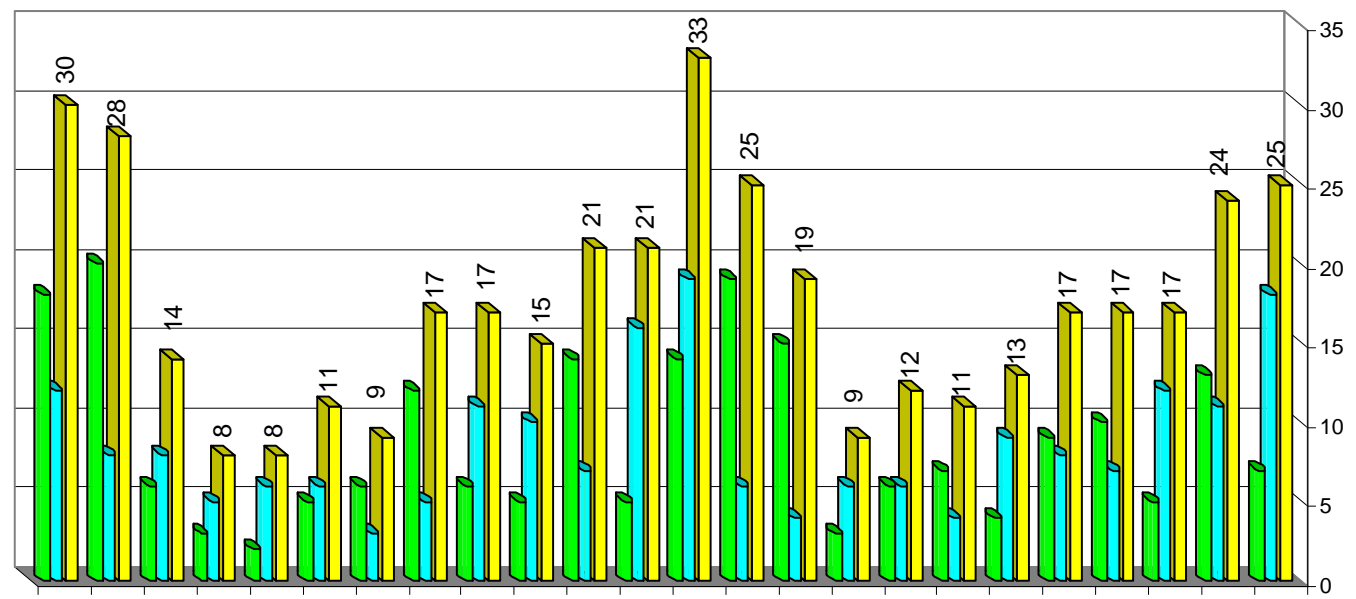

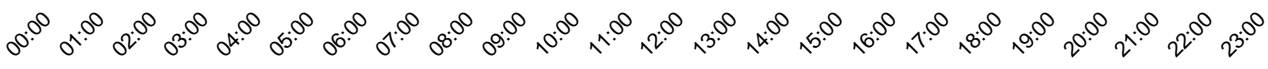
$\square$ Partida $\square$ Chegada $\square$ Total 
Movimento de aeronaves por hora no aeroporto de SBSP, dia $30 / 08 / 2006$

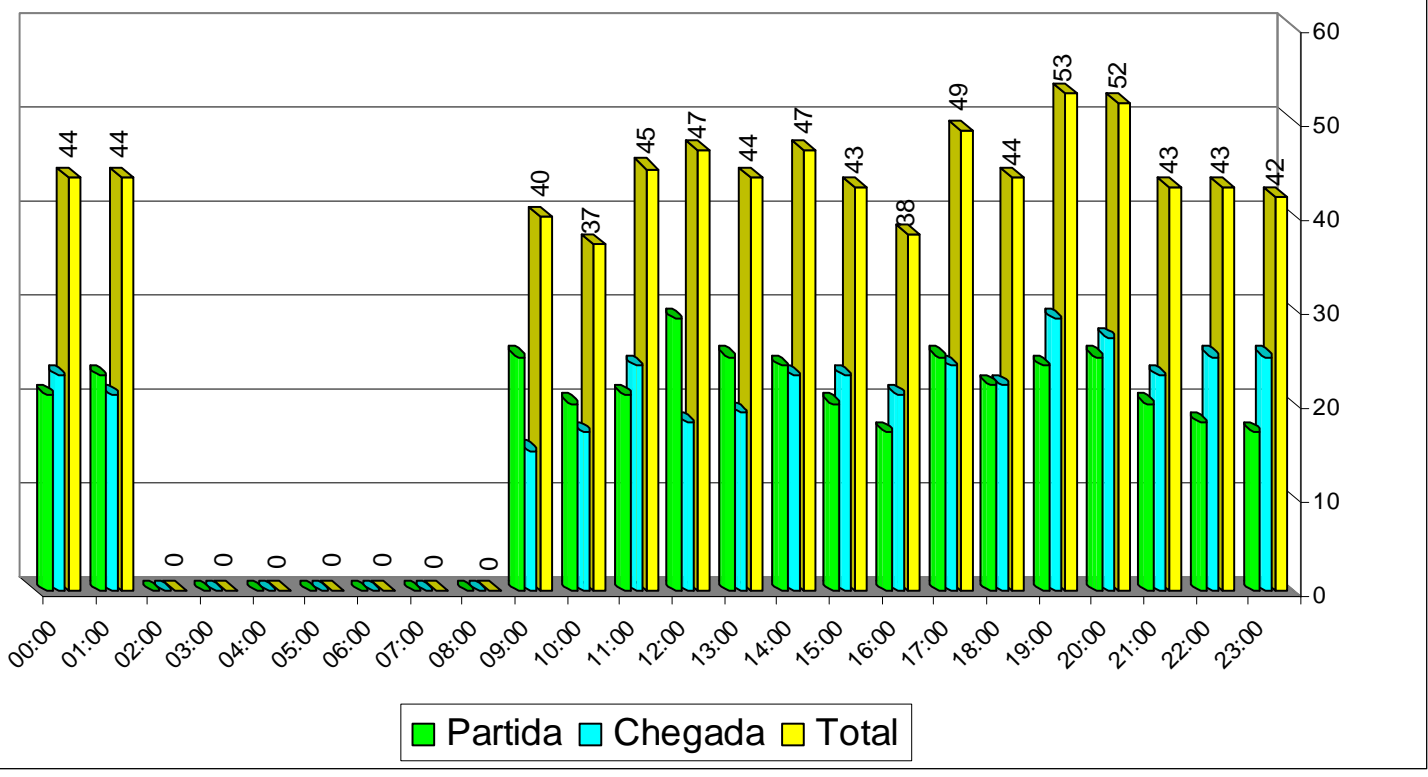

Movimento de aeronaves por hora no aeroporto SBMT, dia $30 / 08 / 2006$

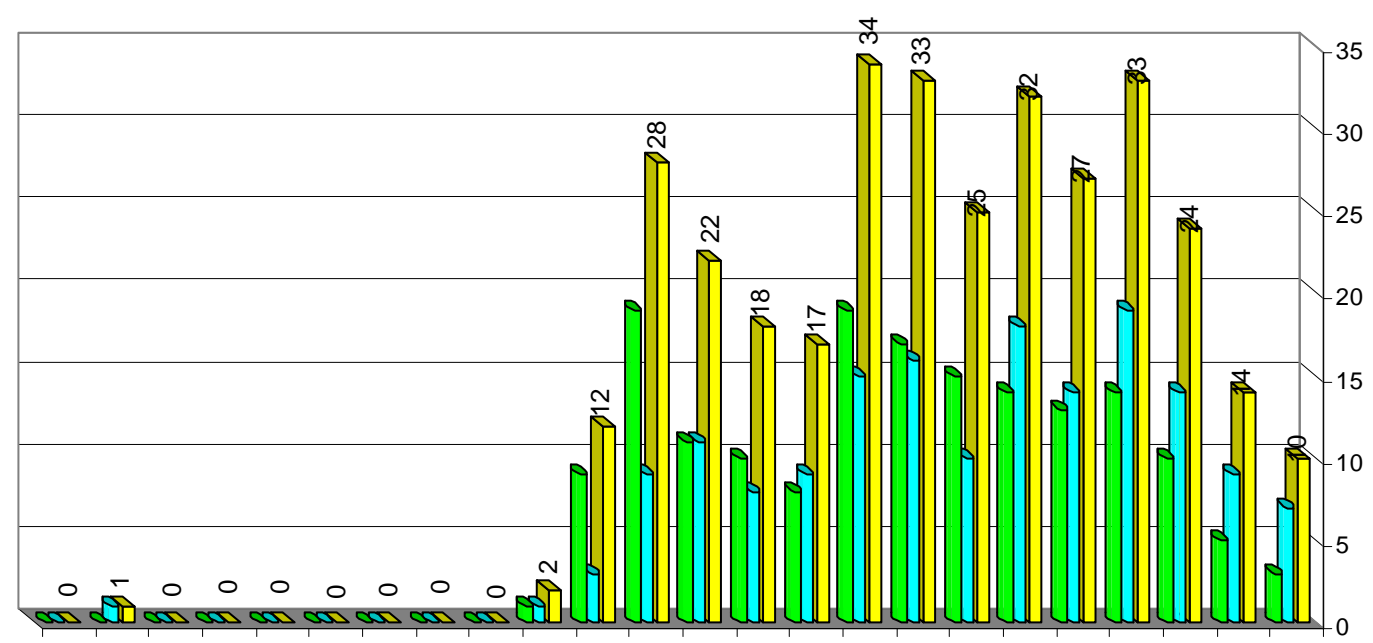

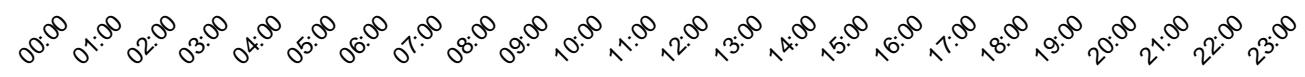


Movimento de aeronaves por hora no aeroporto de SBKP, dia 30/08/2006

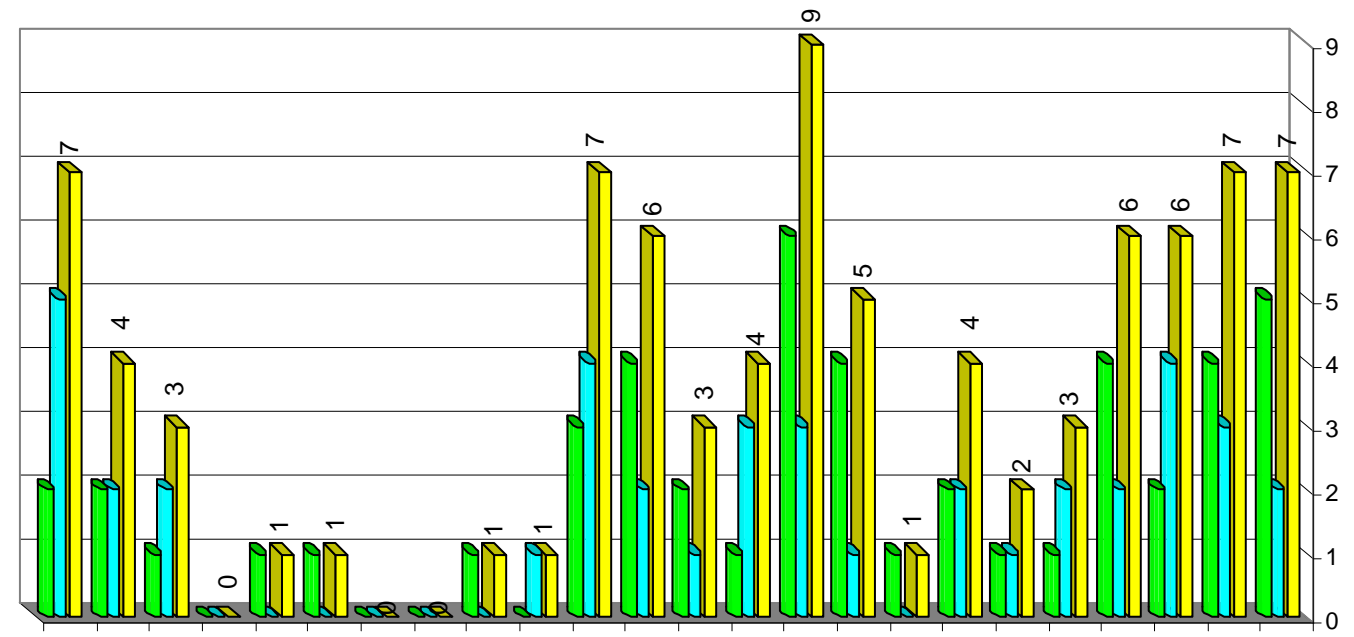

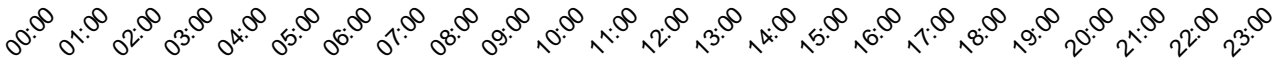

$\square$ Partida $\square$ Chegada $\square$ Total

Movimento de aeronaves por hora na TMA-SP, dia04/09/2006

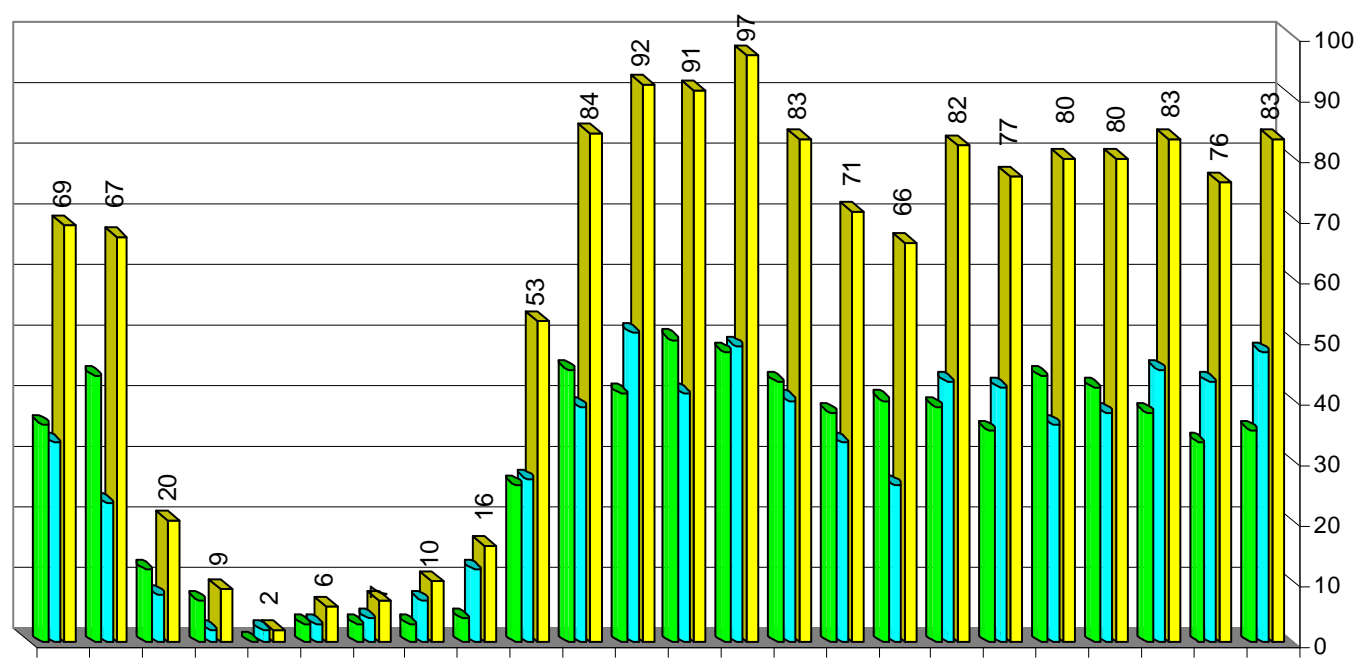

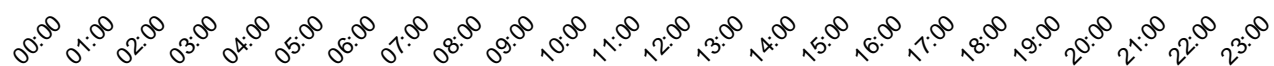




\section{Movimento de aeronaves por hora no aeroporto de SBGR, dia 04/09/2006}

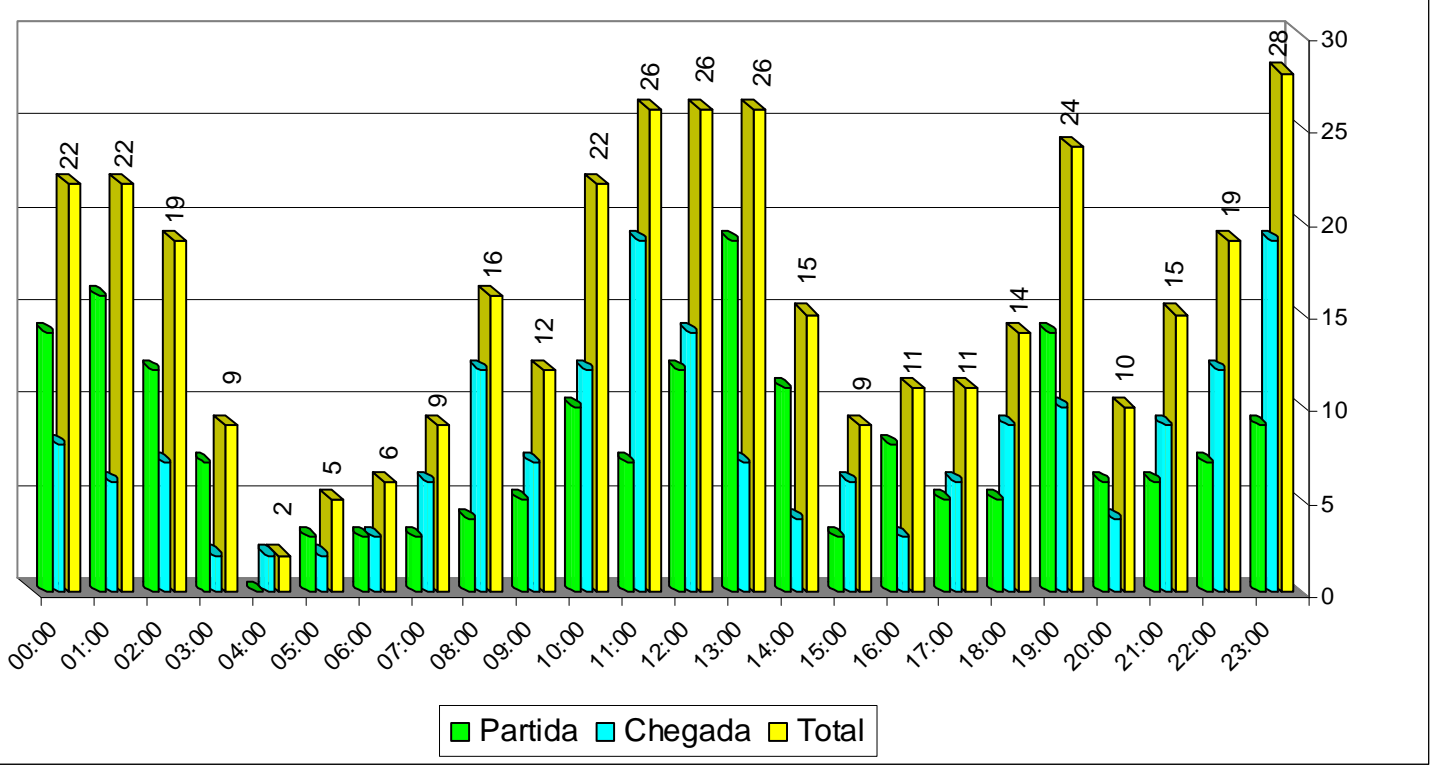

\section{Movimento de aeronaves por hora no aeroporto de SBSP, dia 04/09/2006}

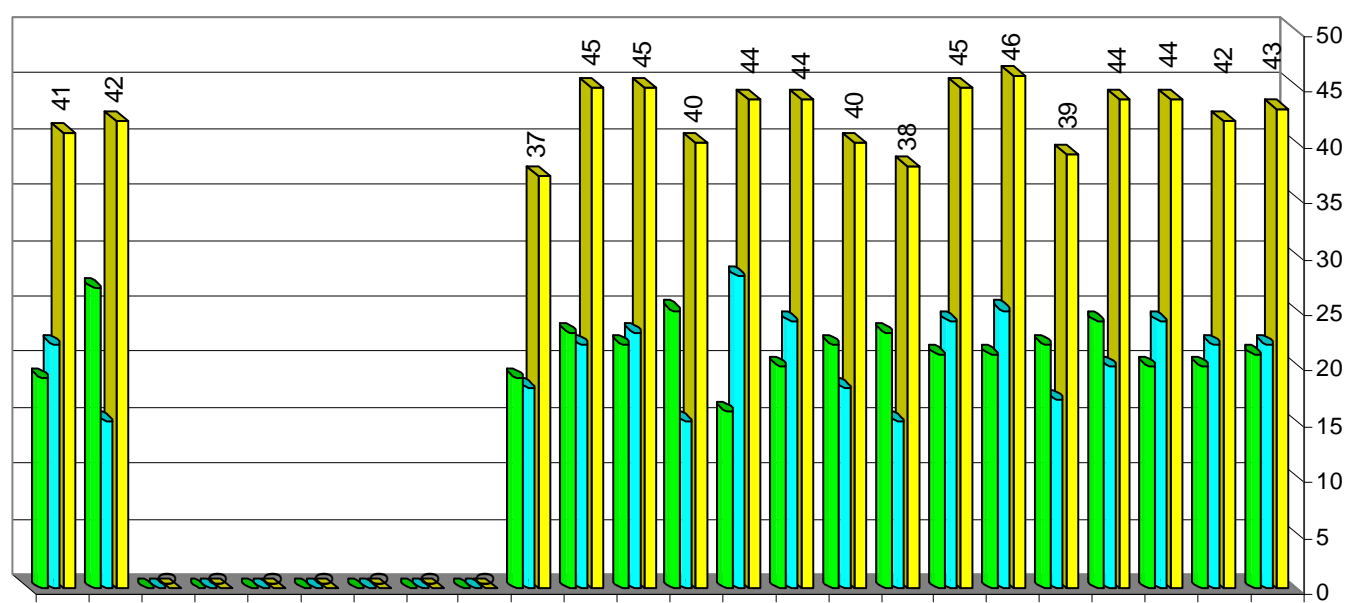

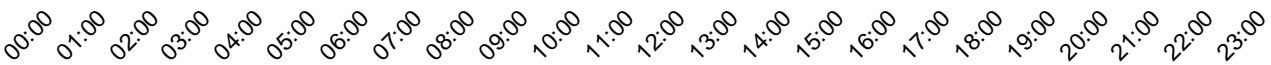




\section{Movimento de aeronaves por hora no} aeroporto SBMT, dia 04/09/2006

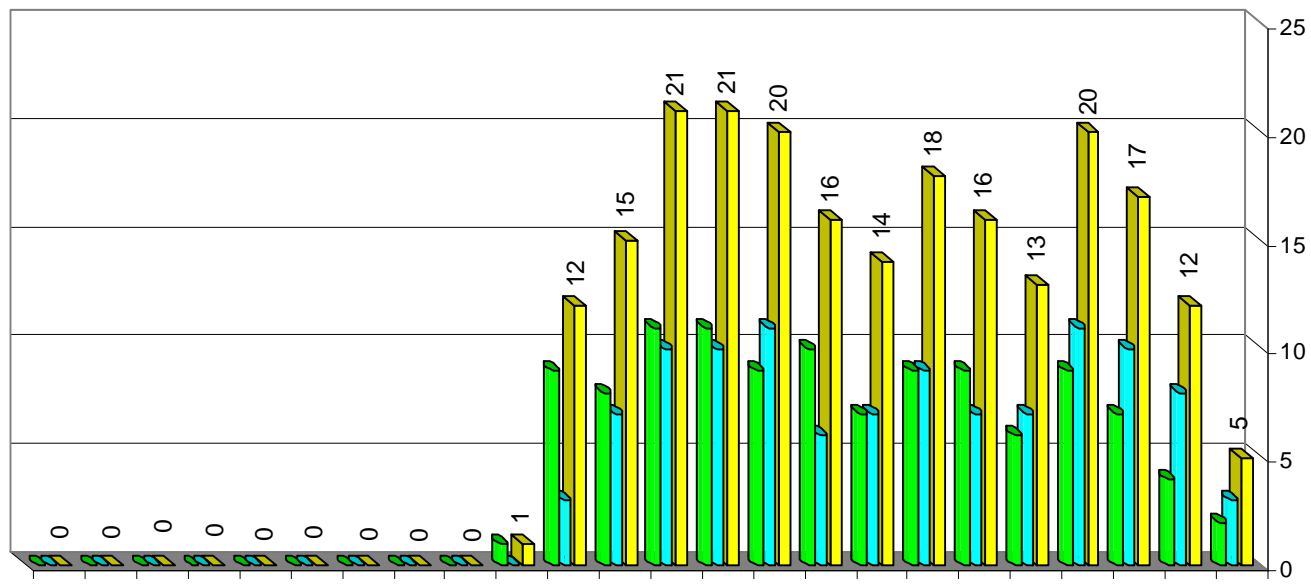

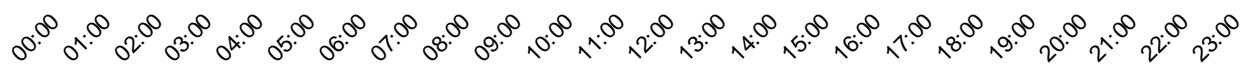

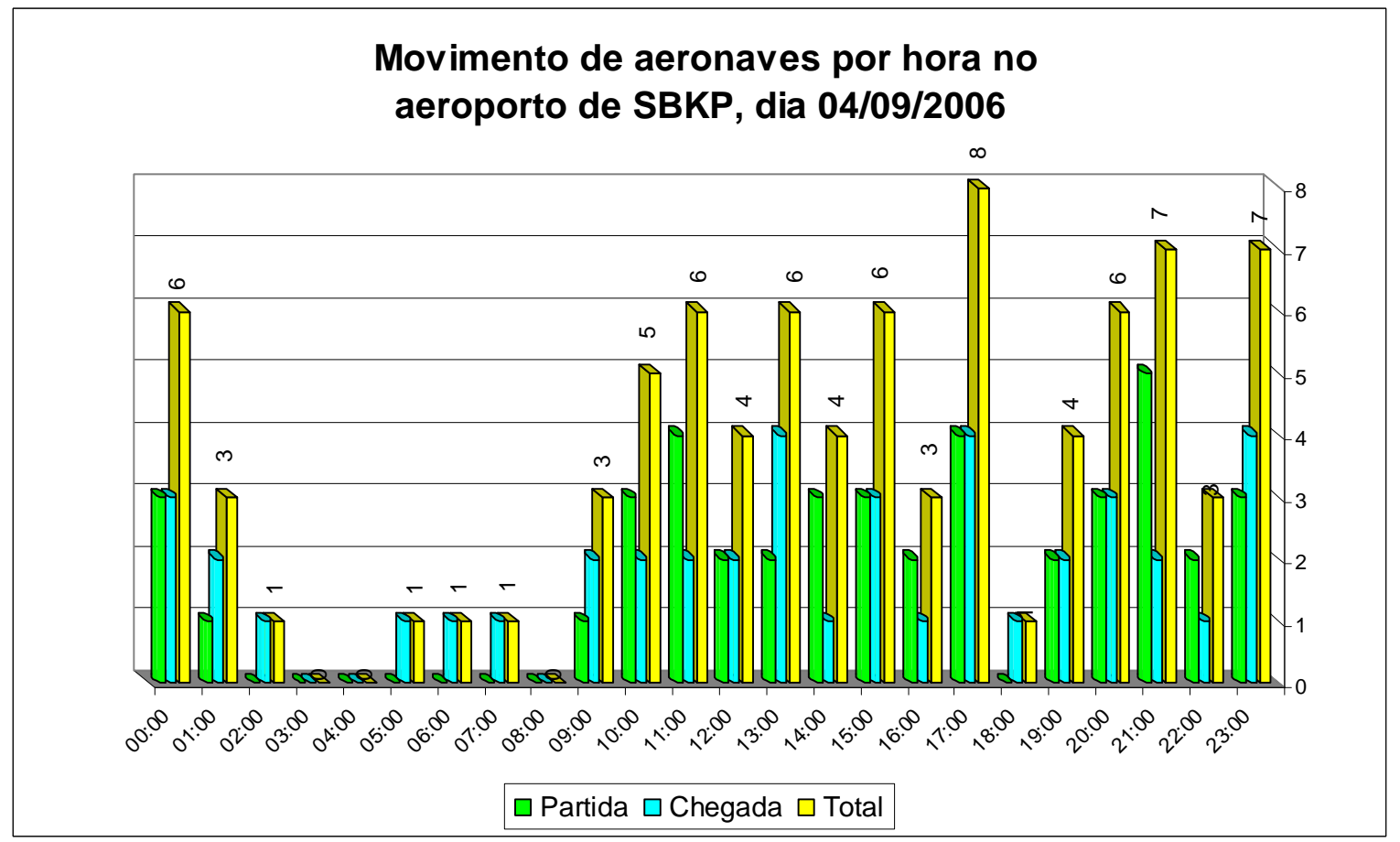




\section{ANEXO II - Resultados das Simulações Utilizando o Tráfego de 04/09/2006 e o Esperado para 2015}
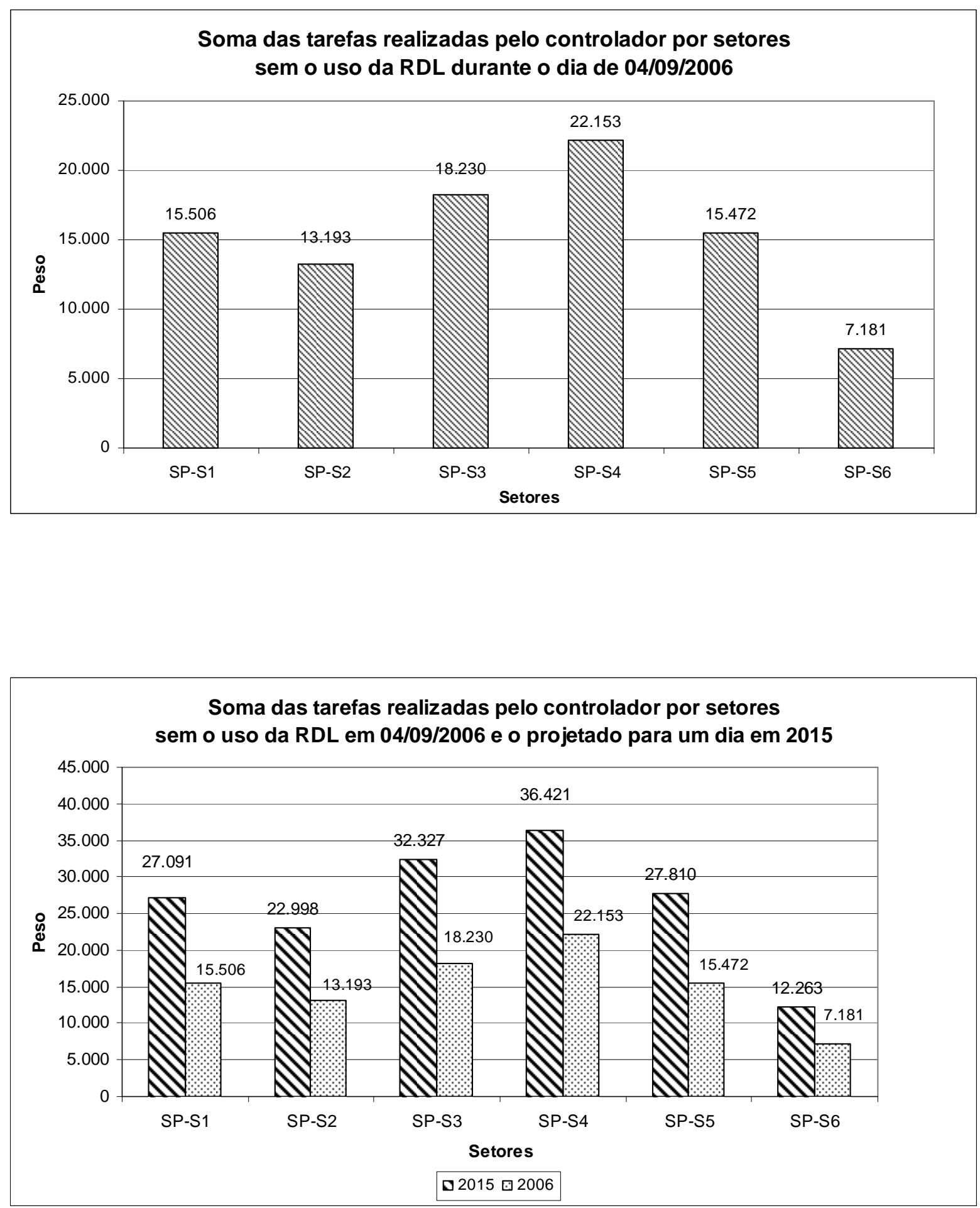

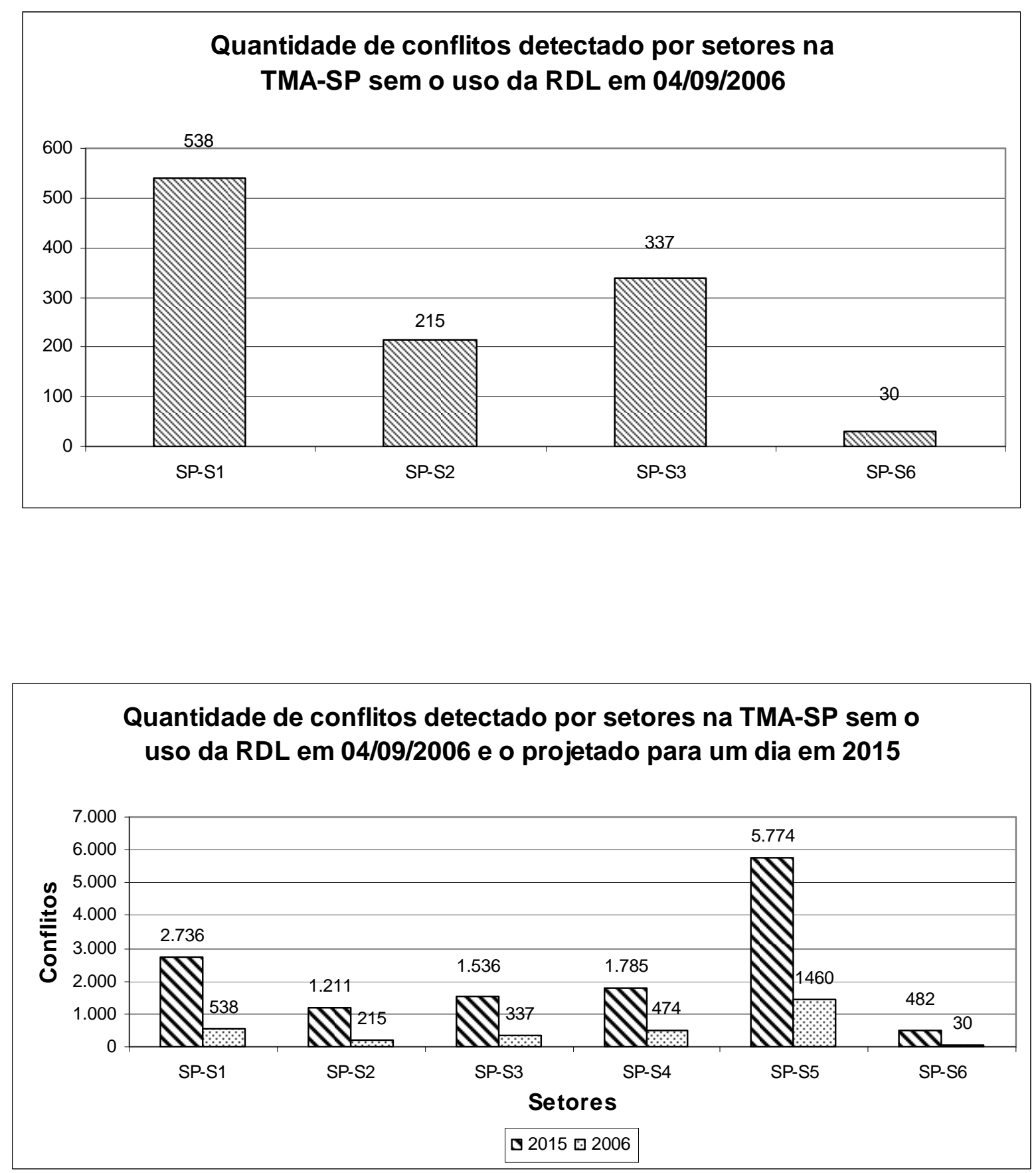